DENILSON JOSÉ MARCOLINO DE AGUIAR

ESTUDO DA FORMAÇÃO E REVERSÃO DE MARTENSITA INDUZIDA POR DEFORMAÇÃO NA AUSTENITA DE DOIS AÇOS INOXIDÁVEIS DÚPLEX 
DENILSON JOSÉ MARCOLINO DE AGUIAR

\section{ESTUDO DA FORMAÇÃO E REVERSÃO DE MARTENSITA INDUZIDA POR DEFORMAÇÃO NA AUSTENITA DE DOIS AÇOS INOXIDÁVEIS DÚPLEX}

Tese apresentada à Escola Politécnica da Universidade de São Paulo para obtenção do título de Doutor em Engenharia

Área de Concentração:

Engenharia Metalúrgica e de Materiais

Orientador:

Prof. Dr. Angelo Fernando Padilha

São Paulo

2012 


\section{Este exemplar foi revisado e alterado em relação à versão original, sob responsabilidade única do autor e com a anuência de seu orientador.}

São Paulo, de setembro de 2012.

Assinatura do autor

Assinatura do orientador

FICHA CATALOGRÁFICA

Aguiar, Denílson José Marcolino de

Estudo da formação e reversão da martensita induzida por deformação na austenita de dois aços inoxidáveis dúplex /

D.J.M. de Aguiar. -- ed.rev. -- São Paulo, 2012.

$147 \mathrm{p}$.

Tese (Doutorado) - Escola Politécnica da Universidade de São Paulo. Departamento de Engenharia Metalúrgica e de Materiais.

1. Aço inoxidável dúplex 2. Martensita induzida por deformação I. Universidade de São Paulo. Escola Politécnica. Departamento de Engenharia Metalúrgica e de Materiais II. t. 


\section{DEDICATÓRIA}

Dedico esta tese aos meus pais que me deram todo o apoio e suporte para que o dia de hoje chegasse. Um sonho que sonhamos juntos e hoje se tornou realidade! Dedico também especialmente à minha noiva Deize Basílio dos Santos que foi muito importante nos momentos em que as coisas pareciam difíceis e impossíveis. Ela teve paciência e me motivou para que o trabalho fosse concluído. A jornada foi árdua, porém, vitoriosa. Esse momento de glória não é só meu, é nosso! Obrigado! 


\section{AGRADECIMENTOS}

Gostaria, neste espaço, agradecer às pessoas que deram todo suporte necessário e foram, direta ou indiretamente, colaboradores para a realização deste trabalho.

Primeiramente, ao professor Dr. Angelo Fernando Padilha, pela amizade, compreensão, motivação e orientação. É impossível deixar de mencionar que foi uma oportunidade ímpar em minha vida. Estes anos de convivência serviram para meu amadurecimento profissional e pessoal. Tendo este homem como espelho, vejo que é possível alcançar o sucesso trabalhando com honestidade, dedicação e amor à ciência.

Agradeço também aos professores e amigos Ronald Lesley Plaut, Nelson Batista de Lima, Manoel Ribeiro da Silva, Márcio Ferreira Hupalo e Osvaldo Mitsuyuki Cintho, que ao longo deste trabalho colaboraram com idéias, técnicas e gentilmente possibilitaram o uso dos seus laboratórios. Sou muito grato ainda aos professores Ronald, Nelson e Manoel por algumas correções de texto.

A jornada de pós-graduação não é nada fácil. No meu caso, por exemplo, estar longe dos familiares e sozinho numa cidade como São Paulo, foi bastante penoso. Por isso, não posso deixar de lembrar os bons amigos que aqui fiz. Conversas nos momentos de solidão, às vezes uma ajuda ou motivação e produtivas discussões sobre os nossos trabalhos tornaram o caminho um pouco mais fácil. Obrigado Angelo, Denise, Eduardo, Evaldo, Fabrício, Leandro, Litzy, Maysa e Tiago!

Não posso deixar de agradecer a todos os funcionários do PMT que sempre estiveram dispostos a ajudar a resolver os problemas do dia-a-dia, em especial, a Suelen, ao "Rubão" e ao Lívio. Obrigado! 


\section{SUMÁRIO}

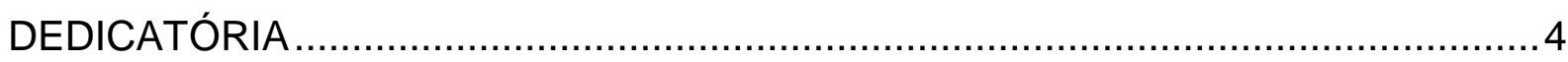

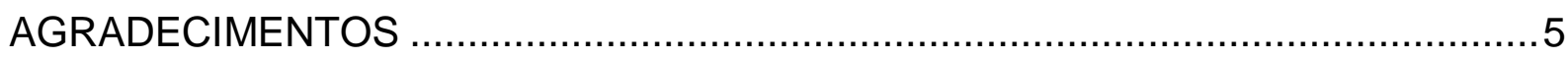

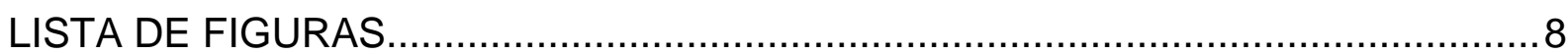

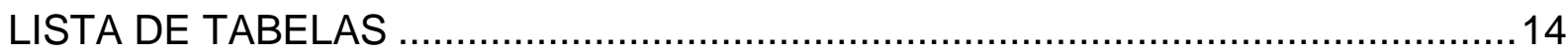

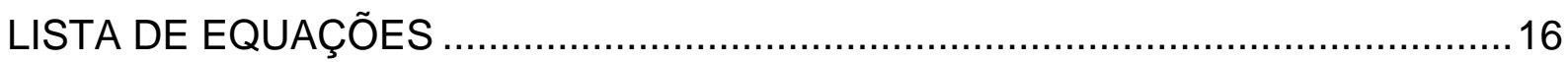

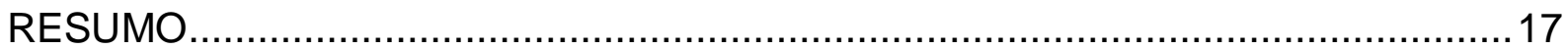

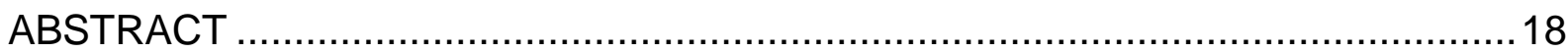

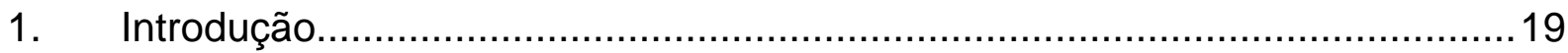

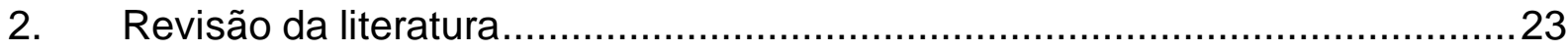

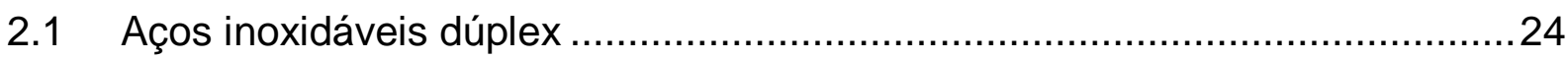

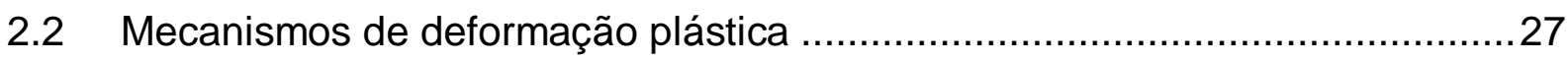

2.2.1 Martensita induzida por resfriamento rápido...................................... 28

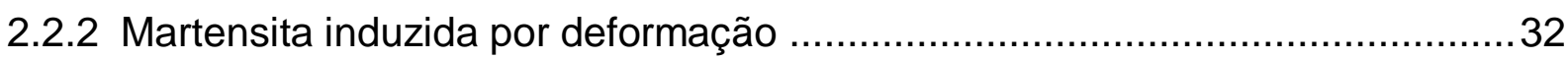

2.2.3 A reversão da martensita para austenita .............................................. 33

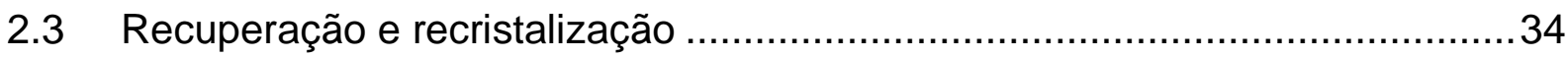

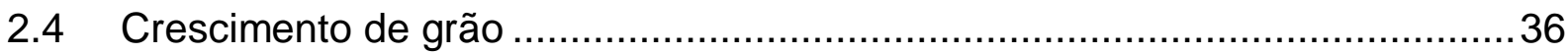

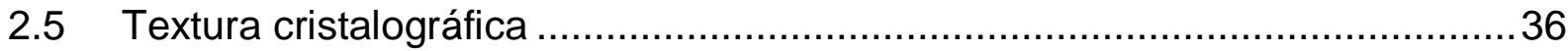

2.6 Propriedades magnéticas dos materiais............................................. 38

2.7 Principais fases presentes nos aços inoxidáveis ......................................40

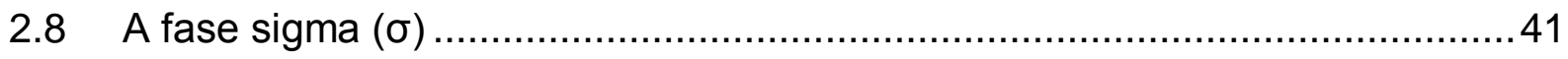

2.9 Outras precipitações de fases importantes.......................................... 45

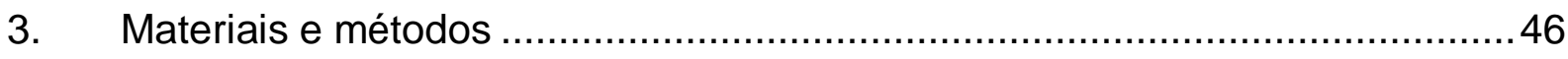

3.1 Caracterização inicial dos aços inoxidáveis dúplex UNS S31803 e super

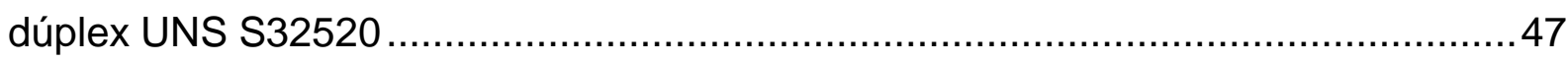

3.2 Métodos utilizados para deformação das amostras ............................... 48 
3.2.1 A deformação pelo método de laminação

3.2.2 A deformação pelo método de limagem dos aços .........................................51

3.3 Técnicas de análise microestrutural utilizadas ............................................52

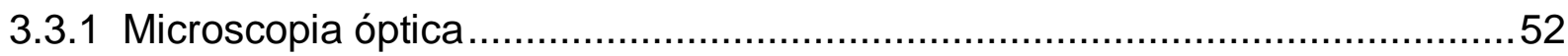

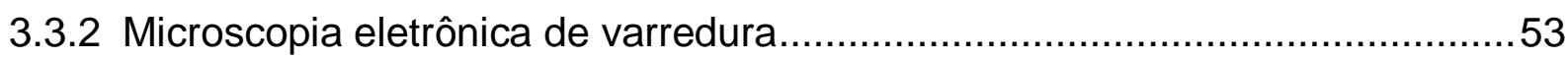

3.3.3 Distribuição granulométrica das partículas de cavaco obtidas por limagem....55

3.3.4 Difração de raios $X$ e refinamento matemático de Rietveld .............................55

3.3.5 Estudo das curvas de dureza das amostras laminadas ...............................60

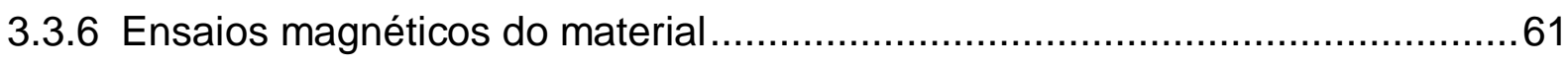

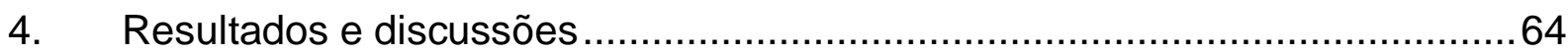

4.1 Resultados iniciais da amostra como recebida (nominalmente solubilizada) ..64

4.2 Curvas de dureza versus redução para a laminação dos aços inoxidáveis

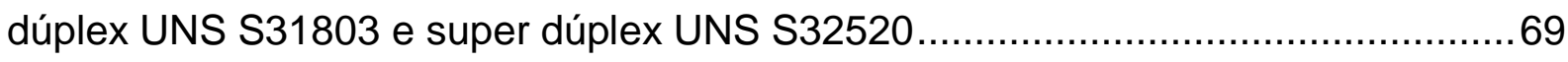

4.3 Distribuição granulométrica das partículas obtidas por limagem .....................70

4.4 Resultados de raios X e refinamento de Rietveld dos cavacos produzidos por limagem dos aços inoxidáveis dúplex UNS S31803 e super dúplex UNS S32520 ...71

4.5 Resultados de raios $\mathrm{X}$ e determinação da microdeformação residual e tamanho de cristalitos das chapas laminadas dos aços inoxidáveis dúplex UNS

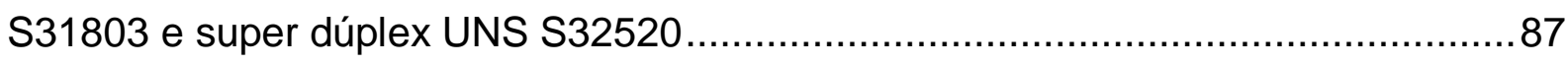

4.6 Comparação entre as microdeformações residuais das amostras deformadas

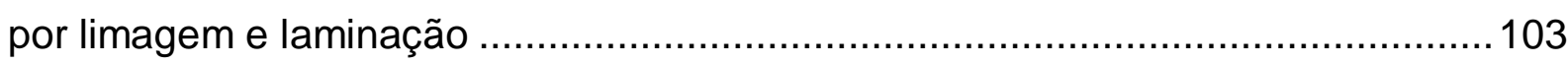

4.7 Determinação dos parâmetros de rede dos aços inoxidáveis dúplex UNS S31803 e super dúplex UNS S32520 .................................................................107

4.8 Histereses magnéticas a partir do ensaio de magnetização..........................112

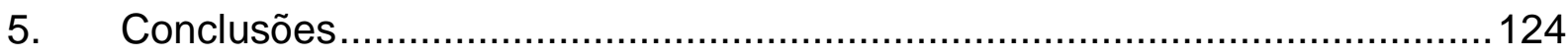

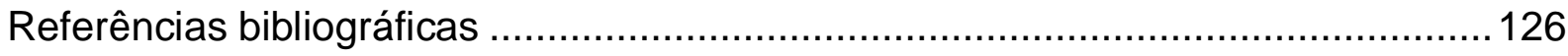




\section{LISTA DE FIGURAS}

Figura 2.1 - llustração de uma microestrutura dúplex laminada a quente, preparada metalograficamente e atacada com reagente de Beraha. RD é a direção de laminação e TD direção transversal à laminação. Região escura representa os grãos de ferrita enquanto as áreas claras representam os grãos de austenita [62]. 26 Figura 2.2 - Representação esquemática da distribuição de discordâncias em grãos encruados - A) arranjo plano de discordâncias homogeneamente distribuídas, como num grão austenítico; B) arranjo celular de discordâncias, como num grão ferrítico [73]. .28

Figura 2.3 - Em (a), célula unitária convencional da austenita, cúbica de face centrada com vetor de base $a_{1}, a_{2}$ e $a_{3}$. Em (b), relação entre a célula cúbica de face centrada com a tetragonal de face centrada $b_{1}, b_{2}$ e $b_{3}$ da austenita. Em (c) célula unitária tetragonal de corpo centrado da austenita sofrendo deformação de Bain no seu parâmetro para cúbica de corpo centrado da martensita (d) [75]. 30

Figura 2.4 - Aspectos fenomenológicos teóricos da cristalografia da martensita. (a) representa o cristal de austenita (c), (d) e (e) têm estrutura cúbica de corpo centrado. (b) tem uma estrutura intermediária entre cúbica de corpo centrado (ou tetragonal de corpo centrado). (c) tem estrutura cúbica de corpo centrado, mas a forma é inconsistente. Aplicando-se uma linha de deformação invariante (por maclação ou deslizamento) é capaz de corrigir os equívocos, resultando na forma e estrutura correta [75].

Figura 2.5 - Imagem de microscopia eletrônica de transmissão, ilustrando ripas de martensita induzida por deformação na austenita do aço inoxidável dúplex UNS S31803 [21]. .33

Figura 2.6 - Diagrama TTT após tratamento de solubilização (curva ) e após 20 \% de redução de espessura (todas as outras curvas). rs = início da recristalização; ts = início da transformação eutetóide $\left(\alpha \rightarrow \sigma+\gamma_{2}\right)$ da ferrita em sigma mais austenita $[54,62]$. .36

Figura 2.7 - Diagrama de Schaeffler, mostrando os campos de existência dos diversos tipos de aço [225].

Figura 2.8 - Diagrama esquemático tempo-temperatura-transformação (TTT) tipo C, mostrando as possíveis transformações de fase [60]. 
Figura 2.9 - Representação da estrutura cristalina tetragonal complexa da fase sigma com as possíveis posições que os átomos podem ocupar [231].

Figura 2.10 - Imagem representando a precipitação da fase sigma. A - microscopia óptica do aço inoxidável super dúplex envelhecido por 12 horas a $800{ }^{\circ} \mathrm{C}$ e B microscopia eletrônica de varredura do aço inoxidável super dúplex envelhecido por 1 hora a $800 \stackrel{\circ}{\mathrm{C}}[234]$.

Figura 3.1 - Fluxograma organizacional dos experimentos realizados no presente trabalho. .46

Figura 3.2 - Laminador de laboratório Fenn, instalado no Departamento de Engenharia de Materiais da Universidade Estadual de Ponta Grossa, PR. .49 Figura 3.3 - Esquema representando picos de difração de raios X. A representação dos picos de um cristal livre de deformações. B - representação dos picos de cristais deformados [240]. 56

Figura 3.4 - Ilustração esquemática da estrutura de blocos, representando um cristal real [240]. .57

Figura 3.5 - Esquema ilustrando a metodologia de determinação da microdeformação residual e tamanho de cristalitos.

Figura 3.6 - Microdurômetro Leica, instalado no Departamento de Engenharia de Materiais na Universidade Estadual de Ponta Grossa, PR.

Figura 3.7 - Magnetômetro de amostra vibrante instalado no Laboratório de Materiais Magnéticos, do Instituto de Ciências Exatas (ICE) da Universidade Federal de Itajubá, MG (UNIFEI).

Figura 4.1 - Microscopia óptica da secção longitudinal do aço inoxidável super dúplex UNS S32520. Amostra atacada metalograficamente por chama de gás de cozinha (GLP) por aproximadamente 1 minuto. 66

Figura 4.2 - Microscopia eletrônica de varredura com elétrons retroespalhados da secção longitudinal do aço inoxidável dúplex UNS S31803.

Figura 4.3 - Microscopia óptica em 3 dimensões do aço inoxidável dúplex UNS S31803. Amostra atacada metalograficamente por chama de gás de cozinha (GLP) por aproximadamente 1 minuto cada uma das faces.

Figura 4.4 - Curva de dureza Vickers (HV1) versus deformação real para os aços inoxidáveis dúplex e super dúplex.

Figura 4.5 - Distribuição de tamanho de partículas produzidas por limagem, do aço inoxidável dúplex UNS S31803. 
Figura 4.6 - Distribuição de tamanho de partículas produzidas por limagem, do aço inoxidável super dúplex UNS S32520.

Figura 4.7 - Partícula de cavaco limado do aço inoxidável super dúplex UNS S31803, tratado a $750 \stackrel{\circ}{\circ}$ por 1 hora. É possível observar as bordas bastante deformadas devido ao processo de limagem. Regiões claras de ferrita e escuras de austenita. .72

Figura 4.8 - Figura de difração de raios $X$ do cavaco produzido por limagem do aço inoxidável dúplex UNS S31803 encruado (preto) e tratados termicamente (conforme legenda). Radiação CuKa.

Figura 4.9 - Detalhe da figura de difração de raios x (Figura 4.8), mostrando apenas os picos (111) da austenita e (110) da ferrita do aço UNS S31803. Radiação CuKa.

Figura 4.10 - Figura de difração de raios $X$ do cavaco produzido por limagem do aço inoxidável super dúplex UNS S32520 encruado (preto) e tratados termicamente (conforme legenda). Radiação CuKa.

Figura 4.11 - Detalhes da figura de difração (Figura 4.10), mostrando apenas os picos (111) da austenita e (110) da ferrita do aço UNS S31520. Radiação CuK $\alpha . . .75$ Figura 4.12 - Quantidade de fases determinada por difração de raios $X$ seguida de refinamento de Rietveld para o aço UNS S31803. .76

Figura 4.13 - Quantidade de fases determinada por difração de raios X seguida de refinamento de Rietveld para o aço UNS S32520. .78

Figura 4.14 - Valores de alargamento dos picos de difração versus sen $\theta$ da ferrita do aço inoxidável dúplex UNS S31803.

Figura 4.15 - Valores de alargamento dos picos de difração versus sen $\theta$ da ferrita do aço inoxidável super dúplex UNS S32520.

Figura 4.16 - Valores de alargamento dos picos de difração versus sen $\theta$ da austenita do aço inoxidável dúplex UNS S31803. 82

Figura 4.17 - Valores de alargamento dos picos de difração versus sen $\theta$ da austenita do aço inoxidável super dúplex UNS S32520. .82 Figura 4.18 - Microdeformação residual da ferrita e austenita nas diversas condições (encruada e tratadas termicamente) do aço inoxidável dúplex UNS S31803.

Figura 4.19 - Microdeformação residual da ferrita e austenita nas diversas condições (encruada e tratadas termicamente) do aço inoxidável super dúplex UNS S32520..87 
Figura 4.20 - Figuras de difração do aço inoxidável dúplex UNS S31803, no estado como recebido (nominalmente solubilizado), com $50 \%$ de laminação e com $93 \%$ de laminação, conforme a legenda de cores. Radiação CuKa.

Figura 4.21 - Figuras de difração do aço inoxidável dúplex UNS S31803, no estado como recebido (nominalmente solubilizado), com $50 \%$ de laminação, bem como tratamentos térmicos individuais de 600 e $650{ }^{\circ} \mathrm{C}$ por 1 hora a partir da condição deformada, conforme a legenda de cores. Radiação CuKa 89

Figura 4.22 - Figuras de difração do aço inoxidável dúplex UNS S31803, no estado como recebido (nominalmente solubilizado), com $93 \%$ de laminação, bem como tratamentos térmicos individuais de 600 e $650{ }^{\circ} \mathrm{C}$ por 1 hora a partir da condição deformada, conforme a legenda de cores. Radiação CuKa.

Figura 4.23 - Figuras de difração do aço inoxidável super dúplex UNS S32520, no estado como recebido (nominalmente solubilizado), com 50 \% de laminação e com $92 \%$ de laminação, conforme a legenda de cores. Radiação CuKa

Figura 4.24 - Figuras de difração do aço inoxidável super dúplex UNS S32520, no estado como recebido (nominalmente solubilizado), com 50 \% de laminação, bem como tratamentos térmicos individuais de 600 e $650{ }^{\circ} \mathrm{C}$ por 1 hora a partir da condição deformada, conforme a legenda de cores. Radiação CuKa.......................92 Figura 4.25 - Figuras de difração do aço inoxidável super dúplex UNS S32520, no estado como recebido (nominalmente solubilizado), com 92 \% de laminação, bem como tratamentos térmicos individuais de 600 e $650^{\circ} \mathrm{C}$ por 1 hora a partir da condição deformada, conforme a legenda de cores. Radiação CuK $\alpha$

Figura 4.26 - Microdeformação residual da ferrita e austenita do aço inoxidável dúplex UNS S31803 em diferentes condições de laminação comparados com o material como recebido (nominalmente solubilizado).

Figura 4.27 - Microdeformação residual da ferrita e austenita do aço inoxidável dúplex UNS S31803 em diferentes condições de laminação comparados com o material como recebido (nominalmente solubilizado) .96

Figura 4.28 - Efeito da temperatura de tratamento térmico de 600 e $650 \stackrel{\circ}{\mathrm{C}}$ por 1 hora na microdeformação residual da austenita e ferrita previamente deformadas de 50 \% de redução por laminação do aço inoxidável dúplex UNS S31803.

Figura 4.29 - Efeito da temperatura de tratamento térmico de 600 e $650 \stackrel{\circ}{\mathrm{C}}$ por 1 hora na microdeformação residual da austenita e ferrita previamente deformadas de 50 \% de redução por laminação do aço inoxidável super dúplex UNS S32520 
Figura 4.30 - Efeito da temperatura de tratamento térmico de 600 e $650 \stackrel{\circ}{\mathrm{C}}$ por 1 hora na microdeformação residual da austenita e ferrita previamente deformadas de $93 \%$ de redução por laminação do aço inoxidável dúplex UNS S31803. 101

Figura 4.31 - Efeito da temperatura de tratamento térmico de 600 e $650 \stackrel{\circ}{\mathrm{C}}$ por 1 hora na microdeformação residual da austenita e ferrita previamente deformadas de 50 \% de redução por laminação do aço inoxidável super dúplex UNS S32520 ......102 Figura 4.32 - Comparação entre as microdeformações residuais da austenita do aço inoxidável dúplex UNS S31803 deformada por limagem e laminação. 104 Figura 4.33 - Comparação entre as microdeformações residuais da austenita do aço inoxidável super dúplex UNS S32520 deformada por limagem e laminação. 105 Figura 4.34 - Comparação entre as microdeformações residuais da ferrita do aço inoxidável dúplex UNS S31803 deformada por limagem e laminação. 106

Figura 4.35 - Comparação entre as microdeformações residuais da ferrita do aço inoxidável super dúplex UNS S32520 deformada por limagem e laminação. 107 Figura 4.36 - Curvas de histerese magnética do aço inoxidável dúplex UNS S31803 nas condições como recebido (CR), laminado a 50 \% e 93 \%, conforme legenda de cores.

Figura 4.37 a - Curvas de histerese magnética do aço inoxidável dúplex UNS S31803 nas condições como recebido (CR), laminado a $50 \%$ sem tratamento térmico, laminado a $50 \%$ e tratado a $600 \stackrel{\circ}{C}$ por 1 hora, laminado a $50 \%$ e tratado a $650 \stackrel{\circ}{\mathrm{C}}$ por 1 hora, conforme legenda de cores.

Figura 4.38 a - Curvas de histerese magnética do aço inoxidável dúplex UNS S31803 nas condições como recebido (CR), laminado a $93 \%$ sem tratamento térmico, laminado a $93 \%$ e tratado a $600 \stackrel{\circ}{C}$ por 1 hora, laminado a $93 \%$ e tratado a $650 \stackrel{\circ}{\mathrm{C}}$ por 1 hora, conforme legenda de cores.

Figura 4.39 - Curvas de histerese magnética do aço inoxidável super dúplex UNS S32520 nas condições como recebido (CR), laminado a 50 e $92 \%$, conforme legenda de cores.

Figura 4.40 - Curvas de histerese magnética do aço inoxidável super dúplex UNS S32520 nas condições como recebido (CR), laminado a $50 \%$ sem tratamento térmico, laminado a $50 \%$ e tratado a $600 \stackrel{\circ}{\mathrm{C}}$ por 1 hora, laminado a $50 \%$ e tratado a $650 \stackrel{\circ}{\mathrm{C}}$ por 1 hora, conforme legenda de cores.

Figura 4.41 - Curvas de histerese magnética do aço inoxidável super dúplex UNS S32520 nas condições como recebido (CR), laminado a $92 \%$ sem tratamento 
térmico, laminado a $92 \%$ e tratado a $600{ }^{\circ} \mathrm{C}$ por 1 hora, laminado a $92 \%$ e tratado a $650 \stackrel{\circ}{\circ}$ por 1 hora, conforme legenda de cores. 118 Figura 4.42 - Cavaco do aço inoxidável dúplex UNS S31803 deformado por limagem, tratado a $600{ }^{\circ} \mathrm{C}$ por 2 horas e tratado a $650{ }^{\circ} \mathrm{C}$ por 2 horas...................121 Figura 4.43 - Cavaco do aço inoxidável super dúplex UNS S32520 deformado por limagem, tratado a $600{ }^{\circ} \mathrm{C}$ por 2 horas e tratado a $650 \stackrel{\circ}{\circ}$ por 2 horas. 122 


\section{LISTA DE TABELAS}

Tabela 2.1 - Valores dos parâmetros para uma microestrutura dúplex ideal [61]....25 Tabela 2.2 - Principais texturas cristalográficas para a austenita e ferrita dos aços inoxidáveis dúplex em diferentes condições [53].

Tabela 3.1 - Composição química (em \% em massa) do aço inoxidável dúplex UNS S31803.

Tabela 3.2 - Composição química (em \% em massa) do aço inoxidável super dúplex UNS S32520.

Tabela 3.3 - Condições de tempo e temperatura de recozimento para os aços inoxidáveis dúplex UNS S31803 e UNS S32520 laminados.

Tabela 3.4 - Condições de tempo e temperatura de recozimento para os aços inoxidáveis dúplex UNS S31803 e UNS S32520 limados.

Tabela 4.1 - Fração volumétrica porcentual de ferrita determinada por estereologia quantitativa e tamanho de grão da ferrita e austenita para os aços dúplex e super dúplex.

Tabela 4.2 - Fração volumétrica de ferrita determinada por ferritoscopia dos aços dúplex e super dúplex.

Tabela 4.3 - Porcentagem em massa dos elementos metálicos na ferrita e na austenita e a partição dos elementos nas duas fases $(\alpha / y)$, determinadas por análise por dispersão de energia dos aços inoxidáveis dúplex e super dúplex.

Tabela 4.4 - Distribuição do tamanho de partículas dos aços inoxidáveis dúplex UNS S31803 e super dúplex UNS S 32520.

Tabela 4.5 - Tamanho de cristalitos (D) e microdeformações residuais $(\varepsilon)$ nas amostras encruada e recozidas conforme Tabela 3.4, para o aços inoxidáveis dúplex e super dúplex.

Tabela 4.6 - Tamanho de cristalitos e microdeformações residuais nas amostras encruada e recozidas conforme Tabela 3.4, para o aços inoxidáveis dúplex e super dúplex.

Tabela 4.7 - Parâmetro de rede da austenita do aço inoxidável dúplex UNS S31803, refinado pelos métodos do $\cos ^{2} \theta$ e $\cos ^{2} \theta / \operatorname{sen} \theta$, comparando-se com o parâmetro refinado pelo programa GSAS, para diversas condições listadas, juntamente com o parâmetro calculado por fórmula [246] que leva em consideração a presença e porcentagem de elementos químicos. 
Tabela 4.8 - Parâmetro de rede da austenita do aço inoxidável super dúplex UNS S32520, refinado pelos métodos do $\cos ^{2} \theta$ e $\cos ^{2} \theta / \operatorname{sen} \theta$, comparando-se com o parâmetro refinado pelo programa GSAS para diversas condições listadas, juntamente com o parâmetro calculado por fórmula que leva em consideração a presença e porcentagem de elementos químicos.

Tabela 4.9 - Tabela de resumo dos resultados de saturação magnética, coercividade $(\mathrm{Hc})$ e remanência $(\mathrm{Mr})$, bem como a massa utilizada no ensaio, para o aço inoxidável dúplex UNS S31803. 118 Tabela 4.10 - Tabela de resumo dos resultados de saturação magnética, coercividade $(\mathrm{Hc})$ e remanência $(\mathrm{Mr})$, bem como a massa utilizada no ensaio, para o aço inoxidável super dúplex UNS S32520. 


\section{LISTA DE EQUAÇÕES}

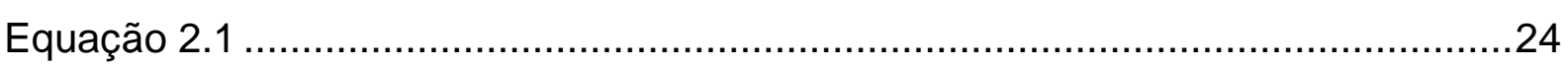

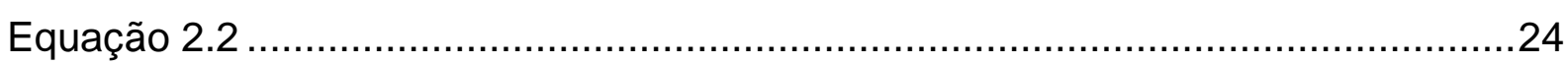

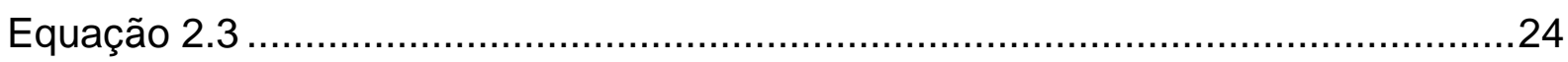

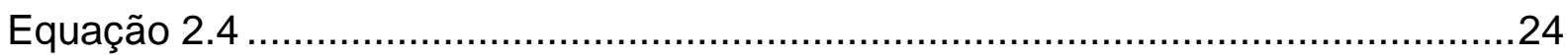

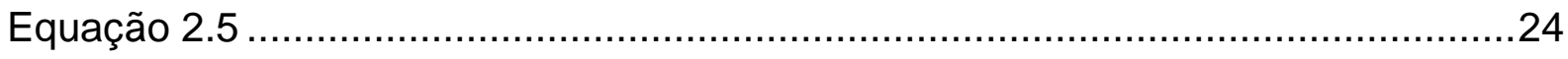

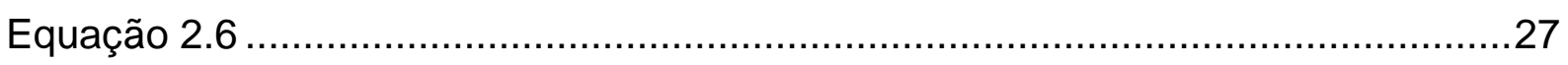

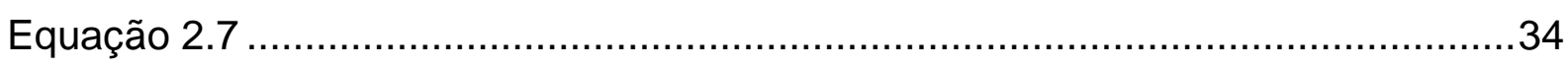

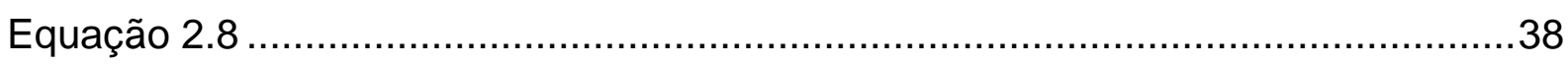

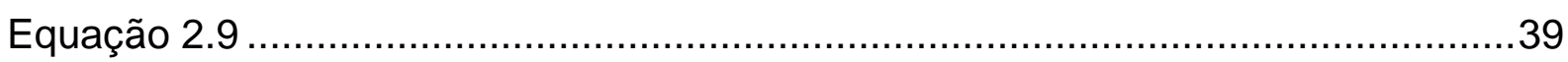

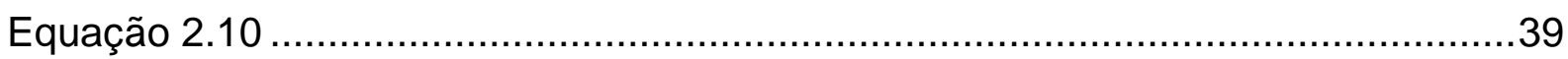

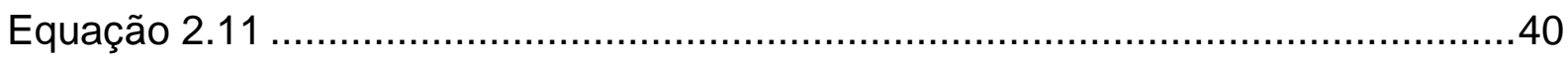

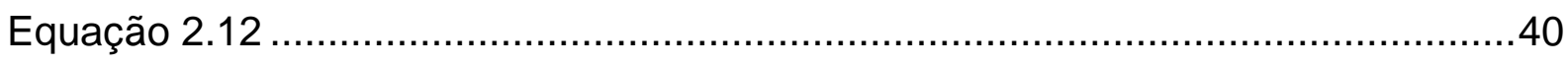

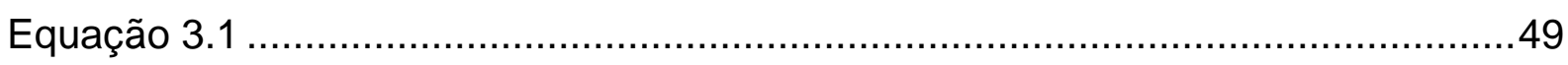

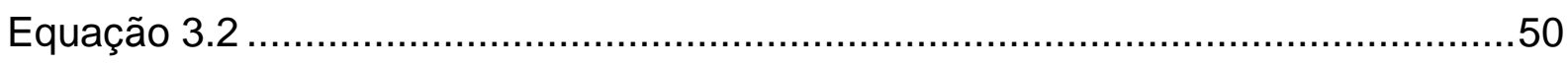

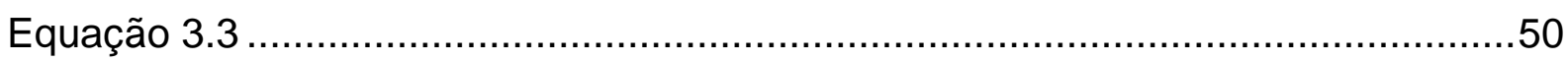

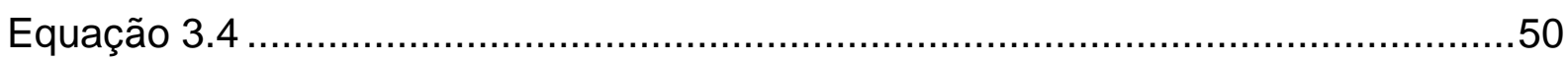

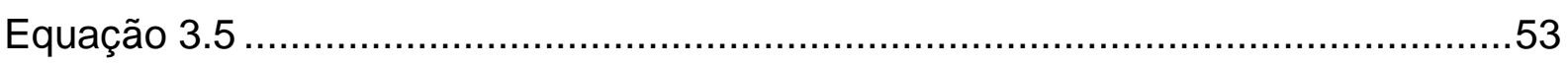

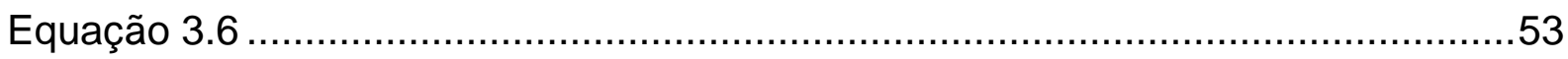

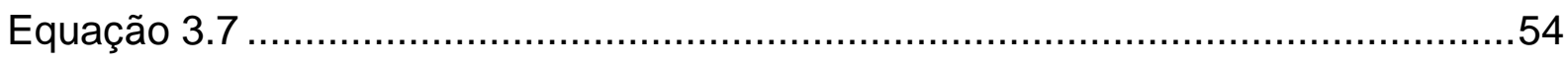

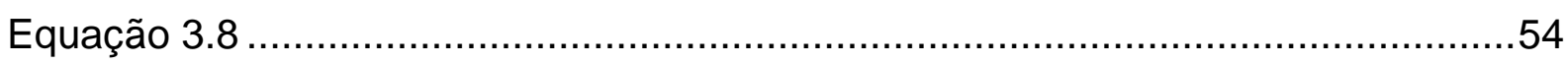

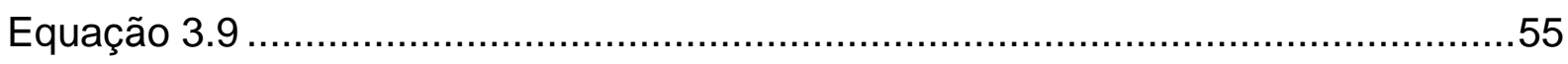

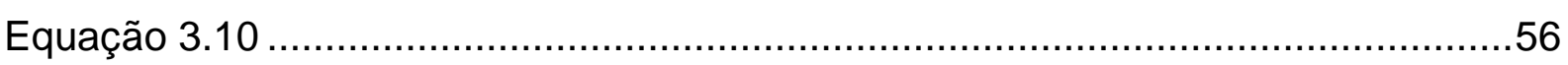

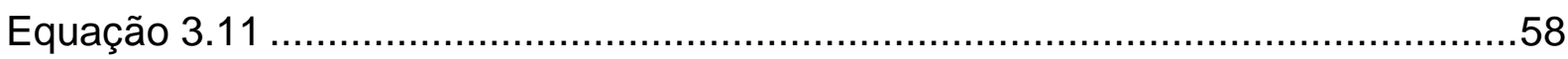

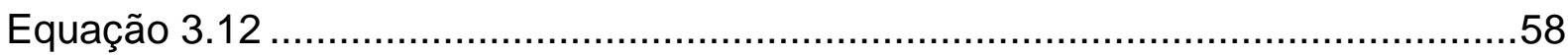

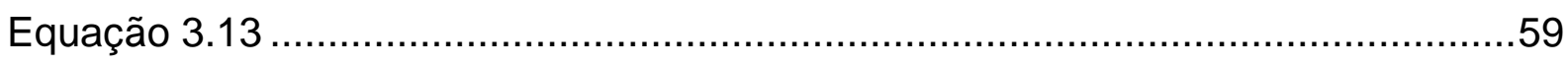

Equação 3.14

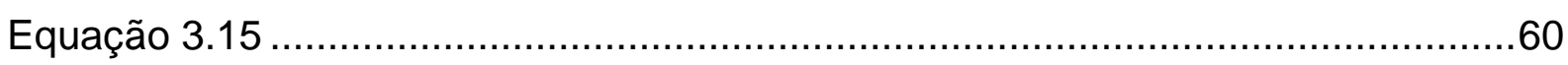

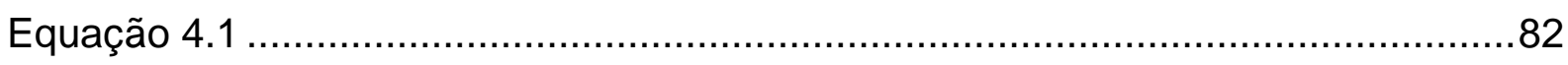

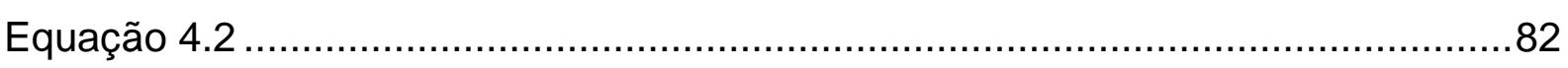




\section{RESUMO}

No presente trabalho foram estudados os fenômenos de encruamento e, principalmente, a formação e reversão da martensita alfa-linha ( $\alpha$ ', cúbica de corpo centrado, CCC, ferromagnética) induzida por deformação em um aço inoxidável dúplex UNS S31803 e um super dúplex UNS S32520. Inicialmente, as microestruturas dos dois materiais na condição solubilizada foram caracterizadas com auxílio de várias técnicas complementares de análise microestrutural. Foram determinadas fração volumétrica, estrutura cristalina, composição química, tamanho e morfologia das duas fases (ferrita e austenita). Posteriormente, os dois aços foram deformados por dois métodos: a laminação a frio, dividida em vários estágios, com menores graus de deformação e a limagem, sendo que o cavaco limado resultante apresenta altos graus de deformação. Algumas amostras deformadas foram recozidas.

Os fenômenos de encruamento, formação e reversão de martensita induzida por deformação na austenita, recuperação, recristalização da austenita e da ferrita no cavaco limado limado foram estudados predominantemente por difratometria de raios $\mathrm{X}$ e usando o método de Rietveld. A difratometria de raios $X$ também foi utilizada para determinação das microdeformações residuais e tamanhos de cristalito (subgrão), calculadas a partir do alargamento dos picos de difração causado pelas deformações. Desta forma, puderam-se comparar os níveis de deformação da laminação e limagem. Qualitativamente, a formação e reversão da martensita induzida por deformação também foi estudada por meio de medidas magnéticas utilizando-se dados de saturação magnética das curvas de histerese obtidas com o auxílio de um magnetômetro de amostra vibrante. Observou-se que para o aço inoxidável dúplex, tanto a laminação quanto a limagem causaram a formação de martensita induzida por deformação e para o aço inoxidável super dúplex, apenas a limagem promoveu essa transformação. Em comparação com o aço dúplex, o aço super dúplex apresentou maior resistência à formação de martensita induzida por deformação, pois apresenta uma austenita mais rica em nitrogênio e uma maior propensão à formação de fase sigma durante o recozimento, pois apresenta uma ferrita mais rica em cromo e nitrogênio.

Palavras-chaves: Aço inoxidável dúplex e super dúplex. Encruamento. Martensita induzida por deformação. Recuperação. Recristalização. 


\begin{abstract}
In the present work the phenomena of strain hardening, formation and reversion of the strain induced alpha-prime martensite ( $\alpha$, body centered cubic, BCC, Ferromagnetic) in an UNS S31803 duplex and UNS S32520 super duplex stainless steels have been studied. Firstly, the microstructures of both materials in the solution annealed condition were characterized with the aid of several microstructural analysis complementary techniques. The volume fraction, crystalline structure, chemical composition, size and morphology of the two phases (ferrite and austenite) have been determined. Further, both steels were deformed by two methods: cold rolling, divided into several stages, with lower strain levels than filing, which the chips resulting had higher strain levels. The phenomena of strain hardening, formation and reversion of strain induced martensite in the austenite phase, recovery and recrystallization of austenite and ferrite phases have been studied, mainly using $X$ ray diffraction and the Rietveld method. X-ray diffraction was also used to determine the residual microstrain and crystallite size (sub grain), calculated from the diffraction peak broadening caused by straining. Thus, the levels of cold rolling and filing strains could be compared. Qualitatively, the formation and reversion of strain induced martensite was also studied by magnetic measurements using data from magnetic saturation of hysteresis curves obtained with the aid of a vibrating sample magnetometer. It has been observed that for the duplex stainless steel, both filing as well as cold rolling promoted strain induced martensite. On the other hand, for the super duplex stainless steel, just filing promoted this transformation. In the comparing with duplex, the super duplex stainless steel austenite is more stable that is why is richer in nitrogen, so, the strain induced martensite formation is more difficult. The easier sigma phase precipitation during annealing as well in the super duplex stainless steel is due higher levels of chrome and molybdenum than the duplex stainless steel.
\end{abstract}

Key words: Duplex and super duplex stainless steel. Strain hardening. Strain induced martensite. Recovery. Recrystallization. 


\section{INTRODUÇÃO}

Em uma recente pesquisa realizada no âmbito desta tese no mês de março de 2012, em dois importantes sítios de busca de trabalhos acadêmicos que são o scopus e web of science, constatou-se que pesquisando por tópicos com os termos duplex stainless steels e strain induced martensite (termos em inglês para aços inoxidáveis dúplex e martensita induzida por deformação, respectivamente), existem perto de apenas 40 trabalhos catalogados com a combinação destes temas [1 - 39]. Além disto, parte destes trabalhos, apesar de muito interessantes, não são rigorosamente pertinentes ao tema, pois tratam de trabalhos sobre aços austeníticos, ferríticos ou ainda de aços dual-phase e, o termo aço inoxidável dúplex, aparece como comparação e não efetivamente como foco da pesquisa.

Os trabalhos voltados à formação de martensita induzida por deformação na austenita dos aços inoxidáveis dúplex relatam que, essa transformação de fase pode ser induzida pelos mais diversos tipos de deformação, tais como em fadiga de baixo ciclo, laminação a frio e tração. Os efeitos da variação de composição química tais como teores manganês e de nitrogênio, a energia de defeito de empilhamento da austenita e também a presença de hidrogênio como elemento facilitador de propagação de trincas (no caso de fragilização por hidrogênio), são variáveis estudadas relacionadas à transformação da austenita em martensita induzida por deformação.

O efeito TRIP (termo em inglês de Transformation Induced Plasticity), que é plasticidade induzida por transformação de fase, tem sido objeto de estudos por promover um aumento de resistência mecânica sem perder a capacidade de conformação, mais amplamente explorados em outros aços que não os dúplex [40 42]. Por este motivo, pode haver um grande interesse tecnológico relacionado ao efeito TRIP na austenita presente na microestrutura dúplex, que consequentemente, pode ser transformada em martensita durante a deformação plástica, promovendo um aumento na resistência mecânica e na ductilidade nos aços inoxidáveis dúplex. De fato, há recentes relatos $[35,36]$ de investigação sobre o efeito TRIP nos aços inoxidáveis dúplex.

Tendo em vista a martensita induzida por deformação em aços inoxidáveis dúplex e sua potencial importância tecnológica, nota-se que os trabalhos, embora 
interessantes, são pouco numerosos. Há uma lacuna de conhecimento e uma grande oportunidade de exploração pode ser vislumbrada dentro deste tema, isto porque as publicações sobre transformação martensítica induzida por deformação, praticamente não abordam a austenita dos aços dúplex.

Os aços inoxidáveis dúplex têm sido crescentemente utilizados em vários segmentos industriais, tais como indústrias química, petroquímica, nuclear e de papel [43 - 45]. Dentre as várias dezenas de composições de aços inoxidáveis dúplex disponíveis no mercado, o aço mais utilizado é o UNS S31803 (22Cr-5,5Ni3Mo-0,15N), também conhecido como DIN 1.4462 (Werkstoff-Nummer), UR $45 \mathrm{~N}$ ou ainda Avesta 2205 [46]. Este aço é usado predominante na condição trabalhada, embora também possa ser utilizado em produtos fundidos. No caso de materiais trabalhados, aços inoxidáveis dúplex sofrem durante o seu processamento pelo menos uma vez os fenômenos de encruamento (deformação plástica), recuperação e recristalização.

Um fator limitador do uso dos aços inoxidáveis dúplex está relacionado às transformações de fases que esta classe de aços está sujeita numa faixa de temperatura que varia de 300 até $1300 \stackrel{\circ}{\circ}$. São conhecidas ao menos 12 significativas transformações e a maioria delas prejudicam as propriedades mecânicas e/ou de resistência à corrosão do material [39].

A primeira descrição detalhada de um aço inoxidável do sistema Fe-Cr-Ni apresentando microestrutura dúplex constituída de ferrita e de austenita, mais tarde denominados aços inoxidáveis dúplex, ocorreu em 1927 [47]. O interesse por esses aços passou a ser importante, próximo aos anos 70 , devido às melhorias nos processos de fabricação. Os aços inoxidáveis dúplex apresentam limite de escoamento aproximadamente duas vezes maior que os aços inoxidáveis ferríticos e austeníticos mais comuns, além de alta resistência à corrosão em ambientes agressivos $[1-3,48]$.

As duas fases presentes na microestrutura dos aços inoxidáveis dúplex apresentam características e comportamentos muito diferentes entre si durante a deformação plástica. A ferrita apresenta numerosos sistemas de deslizamento, alta energia de defeito de empilhamento, não é susceptível a transformações de fases induzidas por deformação e sofre menor encruamento. A austenita tem um número bem menor de sistemas de deslizamento, baixa energia de defeito de empilhamento, é susceptível à formação de fases induzidas por deformação e sofre maior 
endurecimento por deformação ou encruamento [1 - 3].

Durante a deformação plástica ocorre intensa multiplicação de discordâncias nas duas fases. Como a mobilidade das discordâncias é menor na austenita, devida à menor energia de defeito de empilhamento e ao menor número de sistemas de deslizamento na estrutura cúbica de face centrada, para se obter deformações plásticas compatíveis nas duas fases, a densidade de discordâncias na austenita deve ser maior. Além disto, ocorrem na austenita maclação mecânica e a formação de martensitas induzidas por deformação [49 - 53]. O tipo e a quantidade de martensita formada dependem principalmente da composição química da austenita, do grau, da temperatura, da velocidade e do modo ou processo de deformação [8 11].

Durante o recozimento de aços inoxidáveis dúplex deformados a frio ocorrem vários fenômenos na ferrita e na austenita. A ferrita sofre recuperação e recristalização em temperaturas mais baixas que a austenita, pois a difusão na ferrita é muito mais alta $[54,55]$. Por exemplo, o coeficiente de difusão do ferro a 800 ${ }^{\circ} \mathrm{C}$, na austenita é cerca de $10^{-14} \mathrm{~cm}^{2} / \mathrm{s}$, enquanto na ferrita é de $10^{-12} \mathrm{~cm}^{2} / \mathrm{s}$, ou seja, na ferrita é 2 ordens de grandeza mais alta [55]. A austenita também sofre recuperação (menos acentuada que a ferrita) e recristalização, porém em temperaturas mais altas que a ferrita, além da reversão para austenita das martensitas formadas $[12,13,56]$. A reversão da martensita ocorre abaixo da temperatura de recristalização da austenita [10, 11, 57].

A deformação plástica de sistemas bifásicos não está completamente entendida e ainda oferece oportunidades interessantes de pesquisa, especialmente no caso dos aços inoxidáveis dúplex, em que as duas fases (ferrita e austenita) apresentam características muito diferentes entre si. Ao interesse científico, deve-se adicionar a relevância tecnológica, pois a conformação a frio e a morno desta classe de aços também oferece oportunidades de aperfeiçoamento e aplicações. A transformação martensítica induzida por deformação plástica já foi amplamente estudada na austenita dos aços inoxidáveis austeníticos. Porém, é relativamente menos estudada nos aços dúplex, havendo um grande interesse acadêmico e tecnológico nessa investigação. $O$ objetivo geral desta tese é contribuir para 0 entendimento da deformação plástica de sistemas bifásicos, especialmente dos aços inoxidáveis dúplex. O objetivo específico deste trabalho é estudar a transformação parcial da austenita em martensita induzida por deformação plástica em dois aços 
inoxidáveis dúplex de tipos diferentes, verificando a influência da energia de defeito de empilhamento, do teor de nitrogênio na estabilidade da austenita, modo de deformação (laminação e limagem) e graus de deformação nesta transformação de fase. 


\section{REVISÃO DA LITERATURA}

Os aços inoxidáveis são ligas ferrosas que apresentam na sua composição química pelo menos $12 \%$ de cromo. De fato estes aços não são completamente inoxidáveis e sim resistentes à corrosão.

Estudos na Alemanha e Inglaterra em meados de 1910 mostravam a resistência à corrosão em meios ácidos, atribuídas ao aumento do teor de cromo, em ligas à base de ferro, e ainda, o efeito nocivo que o elemento carbono acarretava nessa propriedade. $\mathrm{O}$ aumento da resistência à corrosão mostrava-se significativo a partir de $12 \%$ de cromo e foi associado à teoria da passivação. Uma das explicações sobre a natureza do filme passivador, sugere que a superfície do metal reage com um agente oxidante (normalmente o oxigênio), formando um fino filme superficial rico em cromo, aderente na superfície do aço e invisível a olho nu. Esse filme não é inerte nem estático e, uma vez formado, é de dissolução lenta e contínua em pontos discretos, porém com reparo imediato do filme. O filme funciona como uma barreira entre o metal e o meio, dificultando a corrosão do metal base [44, 58 60]. Outra explicação sobre o filme passivador, que confronta com a primeira, há quase dois séculos, sugere que a película ou camada é adsorvida quimicamente, normalmente de oxigênio ou íons passivadores, diminuindo a velocidade de reação de corrosão [59].

Uma classificação bem comum divide os aços inoxidáveis quanto à sua microestrutura em cinco tipos:

1. Ferríticos;

2. Austeníticos;

3. Martensíticos;

4. Endurecíveis por precipitação;

5. Ferríticos-austeníticos (dúplex).

Neste trabalho, serão abordados alguns conceitos de metalurgia física aplicáveis aos aços inoxidáveis dúplex. Estes conceitos estão divididos em descrição da microestrutura, mecanismos de deformação plástica, definições de recuperação e recristalização, crescimento de grão, textura e principais fases presentes. A fase sigma terá uma atenção especial, pois devido sua rápida cinética 
e ampla faixa de precipitação, bem como os prejuízos ocasionados às propriedades, tornam-na, possivelmente, a mais importante das precipitações.

\subsection{Aços inoxidáveis dúplex}

Os aços inoxidáveis dúplex apresentam microestrutura com duas fases em frações volumétricas comparáveis e distribuição tal que as quantidades de contornos de grão ferrita/ferrita e austenita/austenita seja comparável à quantidade de interfaces ferrita/austenita. A microestrutura pode ser classificada como dúplex com o auxílio de parâmetros de estereologia quantitativa (metalografia quantitativa), descritas matematicamente conforme a abordagem de E. Hornbogen, 1980 apud Rios e Padilha [61]. Para a utilização das grandezas determinadas por metalografia quantitativa, são necessárias as definições de alguns conceitos que podem ser expressos como parâmetro dúplex $\Delta$ (equação 2.1), parâmetro de dispersão $\delta$ (equação 2.2), contiguidade $C_{\alpha}$ (equação 2.3) e $C_{Y}$ (equação 2.4) e razão entre elas (equação 2.5) [61].

$$
\begin{gathered}
\Delta=\frac{S_{v}^{\gamma \gamma}}{S_{v}^{\alpha \alpha}} \\
\delta=\frac{S_{v}^{\alpha \gamma}}{S_{v}^{\alpha \alpha}} \\
C_{\alpha=\frac{2 S_{v}^{\alpha \alpha}}{2 S_{v}^{\alpha \alpha}+S_{v}^{\alpha \gamma}}} \\
C_{\gamma=\frac{2 S_{v}^{\gamma \gamma}}{2 S_{v}^{\gamma \gamma}+S_{v}^{\alpha \gamma}}} \\
\frac{C_{\alpha}}{C_{\gamma}}
\end{gathered}
$$

Equação 2.1

Equação 2.3

Equação 2.4

Equação 2.5

A medida $S_{v}$ representa a área superficial por unidade de volume da amostra teste. O parâmetro dúplex $\Delta$ representa a razão entre quantidade de contornos entre grãos da fase austenita $(\gamma)$ pela quantidade de contornos entre grãos da fase ferrita (a). Já o parâmetro de dispersão $\delta$ representa a razão entre quantidades de interfaces ferrita/austenita pela quantidade de contornos ferrita/ferrita (onde a ferrita 
é a fase matriz). A contiguidade representa o grau de adjacência ou continuidade de cada fase [61].

A tabela 2.1 apresenta os valores de tais parâmetros para a microestrutura dúplex ideal.

Tabela 2.1 - Valores dos parâmetros para uma microestrutura dúplex ideal [61].

Parâmetro

Fração volumétrica

Parâmetro dúplex

Parâmetro de dispersão

Razão de contiguidades

\section{Valor}

$$
\begin{gathered}
V_{v}(\alpha)=V_{v}(\gamma)=\mathbf{0 , 5} \\
\Delta=\mathbf{1} \\
\delta=\mathbf{2}
\end{gathered}
$$

$\mathrm{C}_{\alpha} / \mathrm{C}_{\mathrm{Y}}=\mathbf{1}$

Resumidamente, cada uma das fases tem fração volumétrica de aproximadamente $50 \%$, sendo que uma é cúbica de face centrada (CFC), chamada de austenita, e a outra é cúbica de corpo centrado chamada de ferrita (CCC). A estrutura dúplex é conseguida com o balanço entre elementos químicos alfagênicos, que estabilizam a ferrita (alfa- $\alpha$ ), com elementos químicos gamagênicos, que estabilizam a austenita (gama-y). Este balanço, por sua vez, pode ser calculado por meio dos conceitos de cromo equivalente e níquel equivalente, que será abordado em breve, no capítulo 2.7.

O processamento comum utilizado na produção industrial desses materiais é a laminação à quente, o que propicia obter-se uma microestrutura com lamelas alternadas entre ferrita e austenita, pois a energia interfacial austenita/ferrita é menor que a energia dos contornos ferrita/ferrita ou austenita/austenita. Além disto, esse processamento promove ainda a formação de grãos alongados tridimensionalmente. Essas informações podem ser observadas na figura 2.1 [62] que é uma representação tridimensional dessa classe de aços, que passou pelo processamento de laminação à quente. 


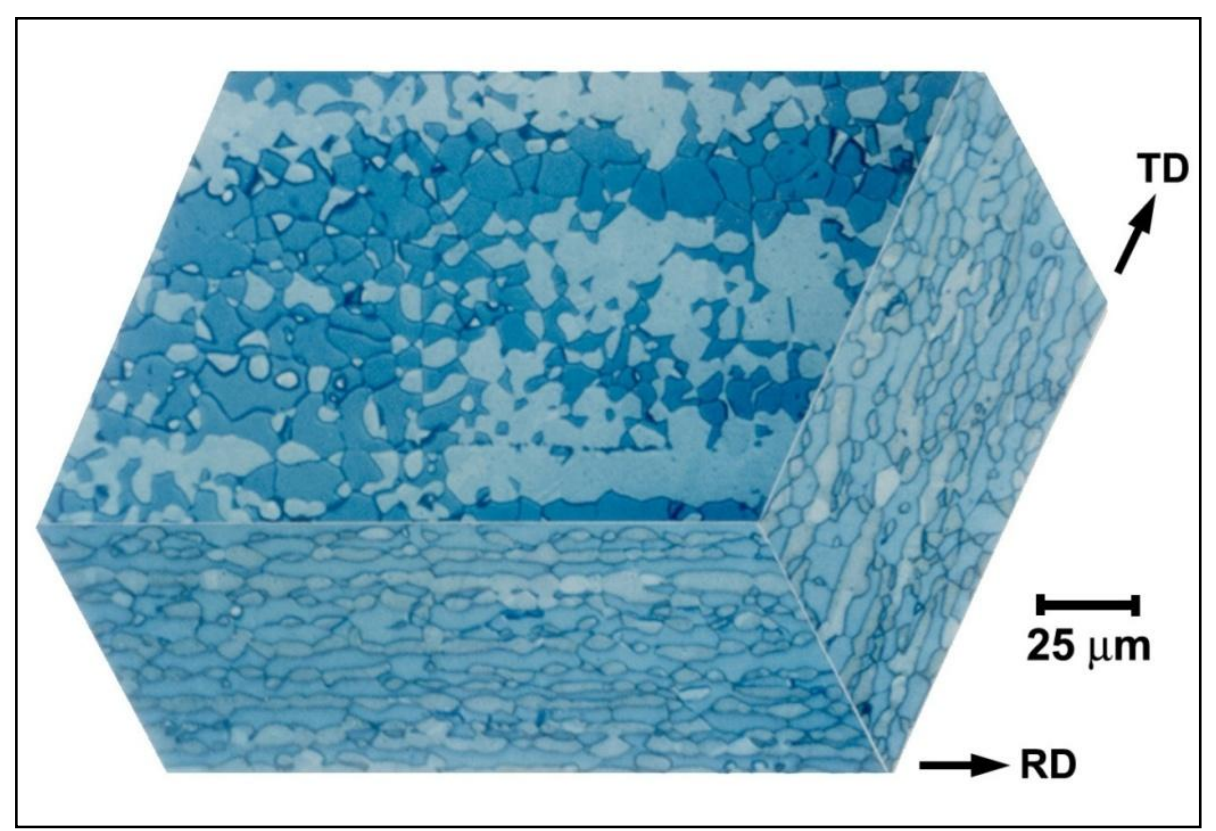

Figura 2.1 - llustração de uma microestrutura dúplex laminada a quente, preparada metalograficamente e atacada com reagente de Beraha. RD é a direção de laminação e TD direção transversal à laminação. Região escura representa os grãos de ferrita enquanto as áreas claras representam os grãos de austenita [62].

Pela presença da ferrita e austenita na microestrutura dos aços inoxidáveis dúplex, há de se esperar uma combinação de propriedades, e de fato há. Entretanto, não obedece a uma simples regra de proporcionalidade de mistura. Por exemplo, a grande quantidade de interfaces ferrita/austenita leva esse tipo de aço ter o limite de escoamento praticamente igual ao dobro dos ferríticos ou austeníticos mais comuns. Outro exemplo, é que a alta quantidade de cromo dessas ligas é responsável pelo excelente comportamento de resistência à corrosão.

Um caso particular dos aços de estrutura dúplex são os denominados superdúplex. A austenita dos superdúplex tem características físico-químicas semelhantes à austenita dos aços inoxidáveis superausteníticos, enquanto a ferrita dos mesmos tem características físico-químicas similares à ferrita dos superferríticos. Os superdúplex compreendem os aços com quantidades de cromo, molibdênio e nitrogênio maiores que a dos dúplex mais comuns, o que resulta em índices de resistência pitting equivalente (PRE) > 40, tornando seu uso bastante satisfatório em ambientes agressivos. Esse índice PRE (termo em inglês de pitting resistence equivalent) é uma medida empírica de resistência à corrosão por pitting baseada na composição química dos aços conforme a equação 2.6. 
PRE $=\%$ peso $\mathrm{Cr}+3,3 * \%$ peso $\mathrm{Mo}+16 * \%$ peso $\mathrm{N}$

Devida à combinação de resistência mecânica e resistência química, as aplicações dos aços de estrutura dúplex são as mais variadas. Como exemplo, válvulas e tubos que entram em contato com água do mar [63, 64], cotovelos de tubulação [65] e resfriadores de compressores [66] em refinarias de petróleo, estruturas de reatores de peróxido [67] na indústria química, estruturas de tanques de armazenamento [68] e digestores [69] na indústria de papel e celulose, estrutura de tanques de transporte de produtos químicos [70], estruturas de pontes de transporte [71], entre outros.

\subsection{Mecanismos de deformação plástica}

Com o surgimento do conceito de discordância e com o subsequente detalhamento da teoria de discordâncias, pôde-se entender a maior facilidade de deformar o material real quando comparado com os valores calculados para um cristal perfeito, já que, as discordâncias têm efeito facilitador da deformação [72].

Todos os materiais reais têm constituintes microestruturais, como fases e inclusões, juntamente com os defeitos cristalinos. A deformação plástica é um processo de introdução de mais defeitos cristalinos no material, principalmente pela multiplicação de discordâncias. Isto ocorre pelo deslizamento de planos preferenciais durante a aplicação de tensões suficientemente elevadas. A quantidade desses defeitos pode ser aumentada em até cem mil vezes, num material, imediatamente após a deformação plástica.

Como supracitado, no processo de deformação plástica há um significativo aumento na quantidade de defeitos cristalinos introduzidos no material, especialmente, pelo aumento da densidade de discordâncias. A forma de distribuição das discordâncias dentro de um grão, por sua vez, está intimamente ligada à estrutura cristalina e à energia de defeito de empilhamento do material. Os materiais com estrutura cúbica de face centrada e de baixa energia de defeito de empilhamento, como por exemplo, a fase austenítica de um aço, têm distribuição homogênea das discordâncias, enquanto materiais de alta energia de defeito de empilhamento, como é o caso da fase ferrítica de um aço, que é cúbica de corpo centrado, têm distribuição heterogênea das discordâncias, formando um arranjo 
celular. Estes tipos de distribuição podem ser observados no esquema representado na figura 2.2 [73]:
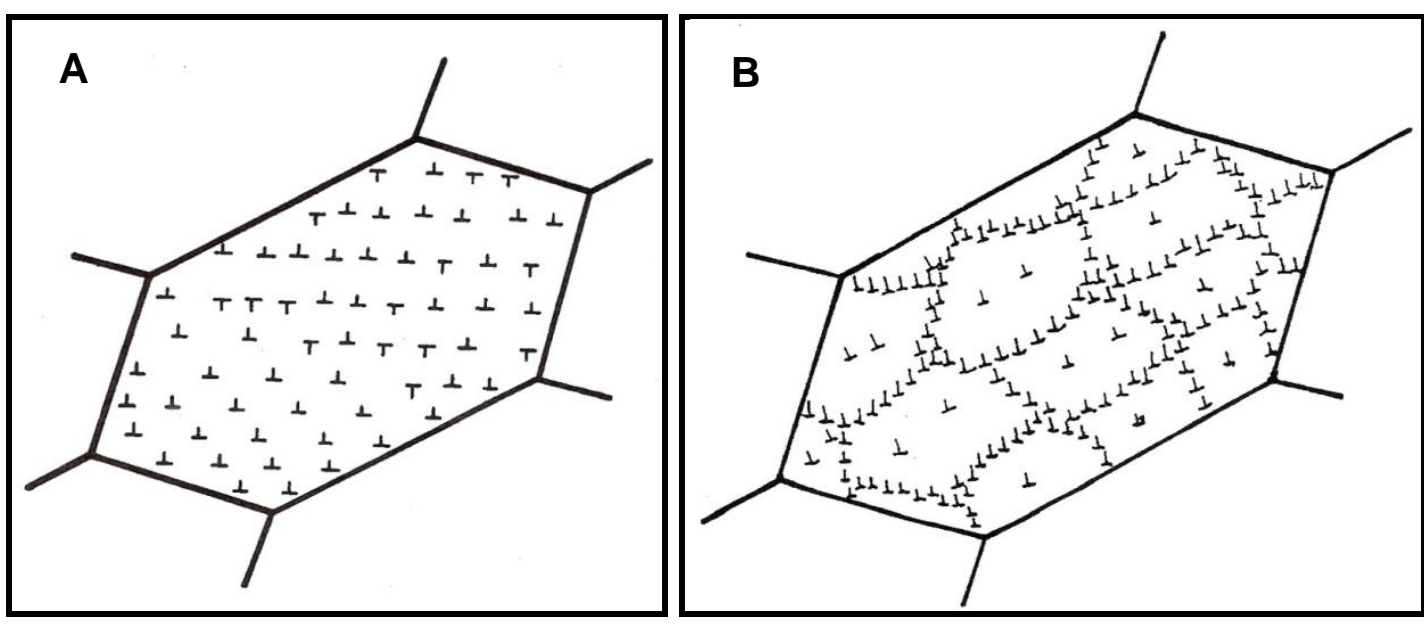

Figura 2.2 - Representação esquemática da distribuição de discordâncias em grãos encruados - A) arranjo plano de discordâncias homogeneamente distribuídas, como num grão austenítico; B) arranjo celular de discordâncias, como num grão ferrítico [73].

Vários processos de conformação são responsáveis pelas deformações plásticas dos materiais. Dentre eles, citam-se os processos de produção de cavaco, por limagem ou moagem de alta energia, ou ainda, pelos processos convencionais de conformação mecânica, tais como laminação a frio e a quente, forjamento a quente e a frio, trefilação a frio e a morno, extrusão a quente, e estampagem, entre outros.

A formação da martensita é uma forma de transformação envolvendo deformação da estrutura cúbica de face centrada, resultando em uma estrutura de cúbica de corpo centrado. Existem na literatura mecanismos que explicam a formação da martensita e que serão brevemente abordados na sequência. Estes mecanismos referem-se à martensita produzida na austenita por severas taxas de resfriamento e à martensita induzida por deformação.

\subsubsection{Martensita induzida por resfriamento rápido}

Quando a deformação ocorre abaixo de uma temperatura limite, associada à composição química do aço, o processo difusional na austenita metaestável é dificultado e a variação de energia livre do sistema favorece um novo tipo de transformação. Neste tipo de transformação, promovido por uma elevada taxa de 
cisalhamento na rede cristalina, a nucleação e o crescimento acontecem numa velocidade próxima à do som no interior da austenita metaestável. A esta transformação descrita dá-se o nome de transformação martensítica. O nome foi dado em homenagem ao seu descobridor, o cientista alemão Adolf von Martens (1850 - 1914), que originalmente estudou a decomposição da austenita metaestável do sistema $\mathrm{Fe}-\mathrm{C}[74]$.

A transformação martensítica é uma reação no estado sólido, não difusional que ocorre de maneira "militar", ou seja, por meio de movimentos coordenados e cooperativos onde os átomos se movem em distâncias menores que o parâmetro de rede, resultando numa microestrutura com alta resistência mecânica e com uma enorme densidade de discordâncias. A alta resistência apresentada por materiais com microestrutura martensítica se deve à combinação e sinergismo de vários mecanismos de endurecimento.

O mecanismo que descreve a transformação martensítica pode ser entendido como uma combinação da deformação de Bain com uma rotação do corpo rígido onde existe ao menos uma linha de deformação invariante. Inicialmente, Bain mostrou a existência de uma célula unitária tetragonal no interior de duas células adjacentes de austenita (cúbica de face centrada). A deformação que converte uma estrutura cúbica de face centrada em uma estrutura cúbica de corpo centrado ou tetragonal de corpo centrado é chamada de deformação de Bain, como esquematizado na figura 2.3 [75]. 


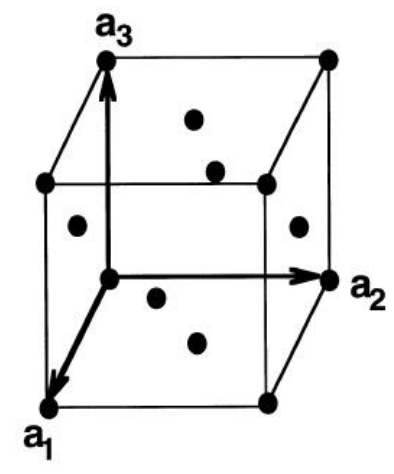

(a)

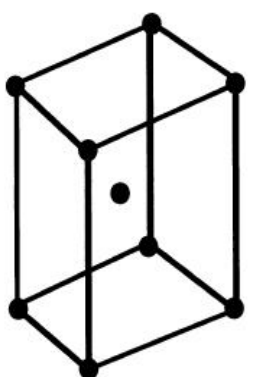

(c)

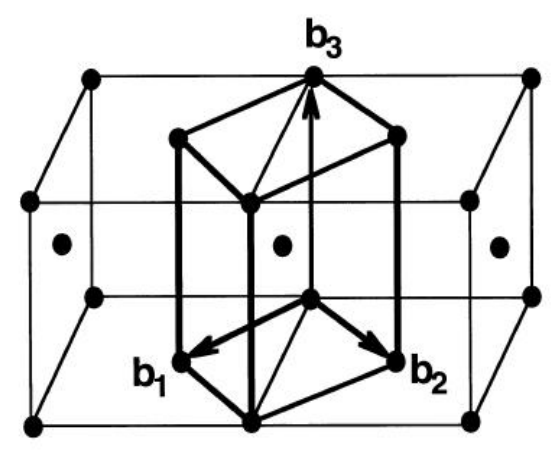

(b)

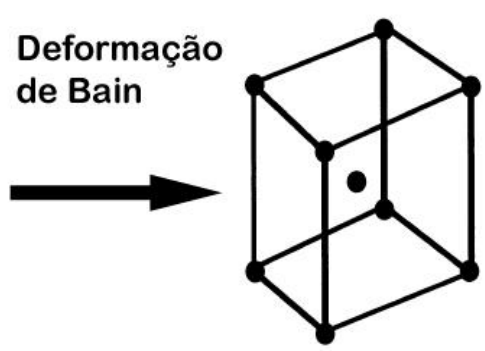

(d)

Figura 2.3 - Em (a), célula unitária convencional da austenita, cúbica de face centrada com vetor de base $a_{1}, a_{2}$ e $a_{3}$. Em (b), relação entre a célula cúbica de face centrada com a tetragonal de face centrada $b_{1}, b_{2}$ e $b_{3}$ da austenita. Em (c) célula unitária tetragonal de corpo centrado da austenita sofrendo deformação de Bain no seu parâmetro para cúbica de corpo centrado da martensita (d) [75].

A célula unitária pode ser convertida pela deformação de Bain, contraindo cerca de $20 \%$ ao longo da direção [001] y e expandindo cerca de $12 \%$ ao longo das direções [110] y e [1 10] ү. Para isso, não necessita do processo de difusão e o átomo pode se mover a uma distância menor que a interatômica. Resumindo, o que Bain propôs foi um cisalhamento simples, onde a célula achata-se num eixo expandindo-se nos outros dois. Porém, somente a deformação de Bain não é suficiente para que a interface de martensita seja móvel. É necessário combinar essa deformação de Bain (B) com uma rotação do corpo rígido $(R)$ onde há deformação homogênea com uma linha invariante macroscopicamente invisível, mas microscopicamente possível onde tanto a forma (P1) quanto a estrutura (P2) estejam corretas, ou seja, R.B = P1.P2 (vide figura 2.4). Este parâmetro invariante acontece por maclação ou por deslizamento, resultando em martensita, cheia de degraus lembrando várias camadas sobrepostas, causada pela presença de $\mathrm{n}$ discordâncias como ilustrado na figura 2.4 [75]. 


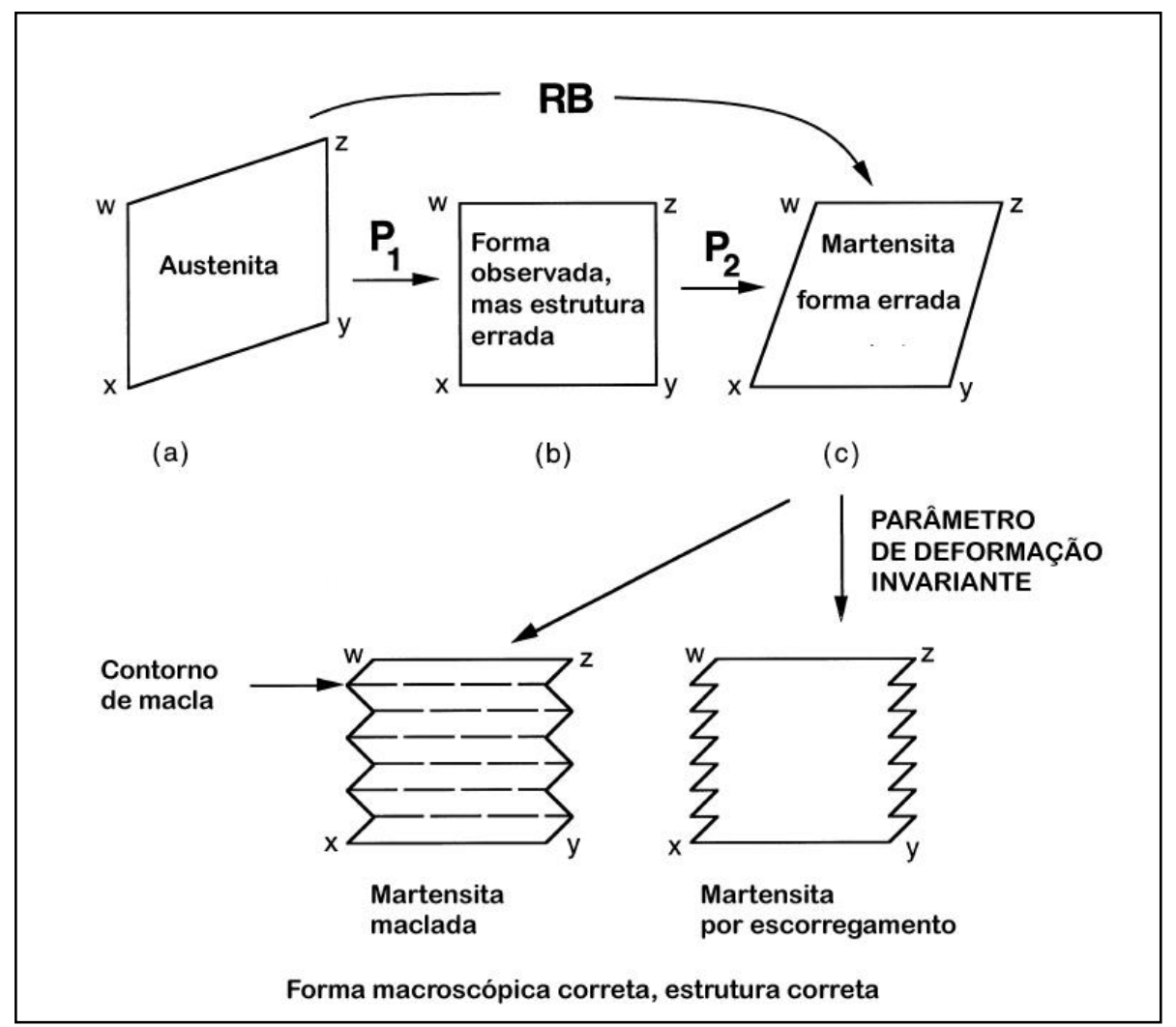

Figura 2.4 - Aspectos fenomenológicos teóricos da cristalografia da martensita. (a) representa o cristal de austenita (c), (d) e (e) têm estrutura cúbica de corpo centrado. (b) tem uma estrutura intermediária entre cúbica de corpo centrado (ou tetragonal de corpo centrado). (c) tem estrutura cúbica de corpo centrado, mas a forma é inconsistente. Aplicando-se uma linha de deformação invariante (por maclação ou deslizamento) é capaz de corrigir os equívocos, resultando na forma e estrutura correta [75].

Um conceito bem estabelecido pela literatura é que a martensita nos aços inoxidáveis austeníticos também pode ser formada pelo choque térmico causado durante o resfriamento rápido a partir de altas temperaturas. Recentemente, evidências apontam que ao contrário dos aços austeníticos, nos aços inoxidáveis dúplex a austenita é mais estável e não existe a formação de martensitas induzidas por resfriamento rápido. Os motivos que respondem por esse impedimento mesmo com resfriamento em temperatura criogênica de $4 \mathrm{~K}$ são [76]:

1. A presença de um campo magnético associado à ferrita;

2. A presença da ferrita restringe a mudança de volume que acompanha a transformação de austenita em martensita. 


\subsubsection{Martensita induzida por deformação}

A literatura publicada nas últimas décadas sobre a ocorrência de martensita induzida por deformação nos aços inoxidáveis dúplex não é muito extensa [1 - 39] e lacunas de conhecimento ainda persistem (conforme citado anteriormente, os estudos desta transformação se restringem praticamente aos aços austeníticos). Nos aços inoxidáveis austeníticos diz-se que a susceptibilidade à formação de martensita induzida por deformação está associada com a diminuição da energia de defeito de empilhamento [50, 52]. Entretanto, a austenita dos aços inoxidáveis dúplex, em geral, tem menor energia de defeito de empilhamento que a dos aços austeníticos devido à composição química. Apesar disso, evidências mostram que a austenita do aço inoxidável dúplex UNS S31803 é menos metaestável que a do aço inoxidável austenítico AISI 304L, consequentemente, para um mesmo nível de deformação o resultado é a formação de uma menor quantidade de martensita induzida por deformação nos dúplex [57]. Além disso, na austenita dos aços inoxidáveis austeníticos é possível a formação de uma estrutura martensítica intermediária do tipo hexagonal compacta, chamada martensita épsilon $(\varepsilon)$. Já no caso da austenita dos dúplex, evidências experimentais apontam apenas a formação de martensita de estrutura do tipo cúbica de corpo centrado, chamada de martensita alfa linha $\left(\alpha^{\prime}\right)$. Embora a martensita induzida por deformação nos aços inoxidáveis dúplex seja de difícil obtenção de imagem, por ser extremamente fina, ela já foi observada por microscopia eletrônica de transmissão, tendo a forma de finas ripas, como mostrado na figura 2.5 [21]. Vale lembrar que este caso citado é uma ocasião especial, pois houve fragilização por hidrogênio, que é mais uma variável que propicia a transformação martensítica induzida por deformação [21]. 


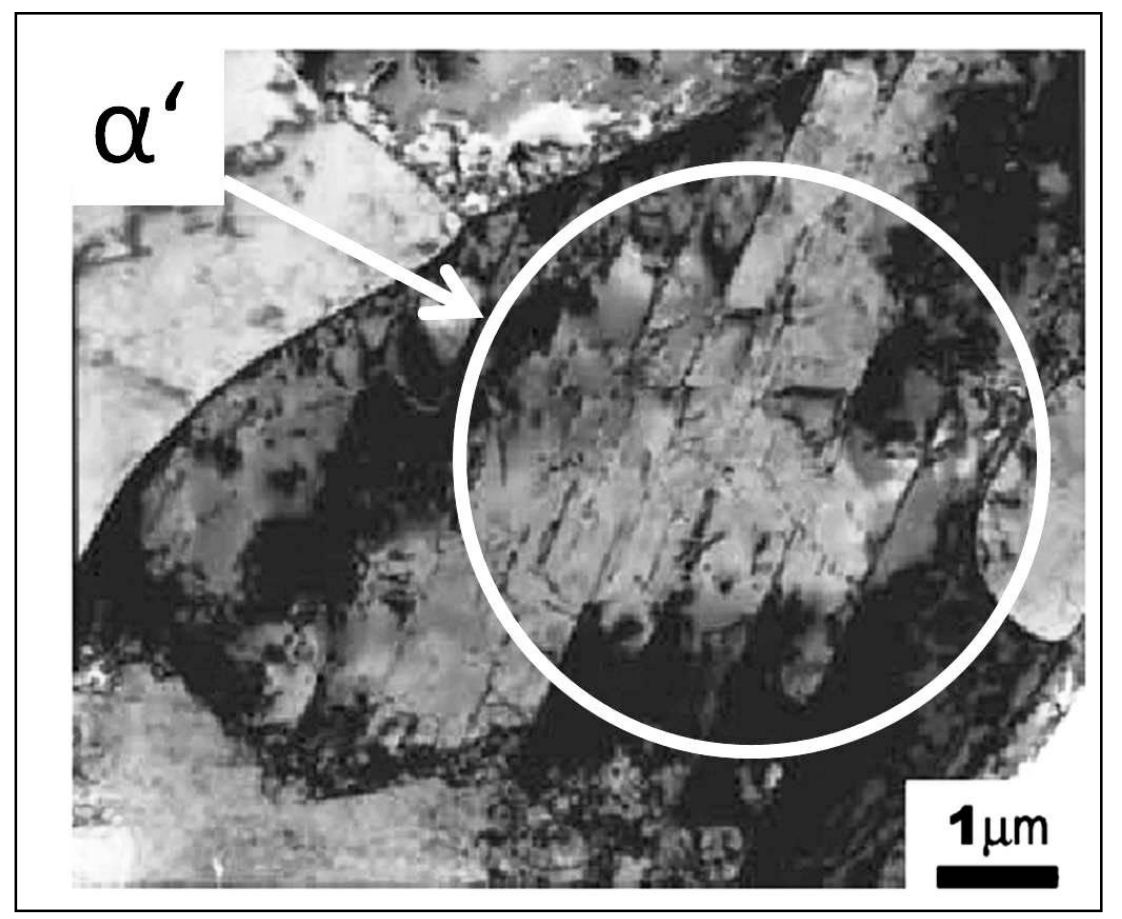

Figura 2.5 - Imagem de microscopia eletrônica de transmissão, ilustrando ripas de martensita induzida por deformação na austenita do aço inoxidável dúplex UNS S31803 [21].

\subsubsection{A reversão da martensita para austenita}

O processo de reversão da martensita é um fenômeno bem menos estudado quando comparado com a sua formação [77]. Trabalhos na literatura apontam que a reversão da martensita ocorre em temperaturas bem abaixo da temperatura de recristalização da austenita, embora, para a reversão completa da martensita essa temperatura possa sobrepor-se com a de recristalização. Mesmo assim, neste caso, a cinética de reversão é muito mais rápida e em apenas 5 minutos a $750 \stackrel{\circ}{ } \mathrm{C}$, por exemplo, um aço inoxidável austenítico pode ter toda a martensita alfa linha revertida para austenita [77].

Um importante trabalho de cunho teórico sobre mecanismo de transformação martensítica, sugere que essa reversão ocorre por duplo cisalhamento, onde a dissociação das discordâncias parciais está presente no processo [78].

Nos aços inoxidáveis austeníticos, evidências experimentais apontam que a reversão da martensita alfa linha em austenita ocorre mais rapidamente por volta de $600 \stackrel{\circ}{C}$ [50]. Para estimar o "alcance" da difusão no tratamento térmico de reversão em 1 hora a $600^{\circ} \mathrm{C}$, usando os coeficientes de difusão do ferro na austenita ( $D$ é aproximadamente $5,55 \times 10^{-18} \mathrm{~cm}^{2} \mathrm{~s}^{-1}$ ) [55] e a equação 2.7, tem-se que $\mathrm{x}$ é 
aproximadamente 14 Angstrons. Usando este mesmo raciocínio e o coeficiente de difusão do ferro na ferrita ( $D$ é de aproximadamente $6,27 \times 10^{-15} \mathrm{~cm}^{2} \mathrm{~s}^{-1}$ ) [55], pela mesma equação 2.7, x é aproximadamente 475 Angstrons.

$x=\sqrt{D \cdot t}$

Equação 2.7

Portanto, é de se esperar que a reversão da martensita tenha uma componente difusional.

Adotando-se uma busca nos sítios de trabalhos acadêmicos, o scopus e web of science, constatou-se que, pesquisando por tópicos com os termos duplex stainless steels, strain induced martensite e reversion (termos em inglês para aços inoxidáveis dúplex, martensita induzida por deformação e reversão), existem apenas 3 trabalhos catalogados com a combinação destes temas [5, 8, 39], sendo que um deles [8] o trabalho é de aço inoxidável austenítico e outro [39] é um artigo de revisão. Constata-se, portanto, que reversão da martensita induzida por deformação é um fenômeno ainda menos estudado que a sua formação. A intenção do presente trabalho é dar uma pequena contribuição no entendimento de algumas condições para a formação e reversão da martensita induzida por deformação na austenita dos aços inoxidáveis dúplex.

\subsection{Recuperação e recristalização}

Tanto a recuperação quanto a recristalização são fenômenos que promovem a diminuição da quantidade de defeitos cristalinos pela ação da temperatura. Quando a orientação dos cristais se mantém sem mudanças bruscas durante o tratamento térmico de um material deformado, diz-se que ele está se recuperando [79]. Durante a recristalização, alguns grãos com determinada orientação crescem consumindo outros de outras orientações. Somente alguns poucos materiais se recristalizam sem mudança brusca de textura, sendo que, na maioria dos materiais metálicos, a textura de recristalização é bem diferente da textura de deformação [79].

O que difere fenômenos de recuperação e recristalização é que na recristalização há migração de contornos de alto ângulo enquanto que na 
recuperação não há. Por isso, a recristalização é um processo que necessita de maior ativação térmica, ou seja, ocorre em temperaturas mais elevadas [79-81].

Quando o material está encruado, diz-se que ele está termodinamicamente instável. Então, o potencial termodinâmico para que ocorra a recristalização é o nível de deformação do material, ou seja, a energia interna armazenada no material pelos defeitos cristalinos, principalmente na forma de discordâncias. À medida que é fornecida temperatura suficiente para difusão dos átomos, essa energia é diminuída pelo rearranjo e diminuição na quantidade de defeitos [81, 82].

Além disso, a recristalização está intimamente ligada a outros fatores tais como grau de deformação, homogeneidade de distribuição dos defeitos cristalinos que por sua vez dependem da energia de defeito de empilhamento, temperatura de tratamento térmico posterior à deformação.

$\mathrm{Na}$ recristalização de um material deformado, contornos de alto ângulo, que têm alta energia e alta mobilidade, se movimentam "varrendo" a microestrutura, isto é, os defeitos puntiformes e discordâncias são absorvidos por esses contornos, fazendo com que a energia livre do sistema seja diminuída [80]. A densidade de discordâncias de uma região recristalizada pode ser cerca de cinco ordens de grandeza $\left(10^{5}\right)$ menor que a de uma região ainda encruada, que chega a ter até $10^{16}$ discordâncias $/ \mathrm{m}^{2}[80,83]$.

Um aspecto importante que deve ser mencionado é que os fenômenos de recristalização e recuperação podem competir entre si. Geralmente, a recuperação tende a retardar a recristalização, pois precisa de menor energia ocorrendo em temperaturas mais baixas e tende a diminuir a densidade de discordâncias, como por exemplo, a recuperação da ferrita dos aços. Há casos em que a temperatura de recuperação situa-se numa faixa de temperatura em que o processo de difusão é dificultado, como por exemplo, a austenita dos aços, sendo nesse caso a recristalização um fenômeno mais evidente [54, 83].

Um diagrama TTT (tempo - temperatura - transformação) de um aço inoxidável dúplex UNS S31803, ilustra os processos de transformação deste material (recuperação, recristalização e precipitação de fase sigma) em função do tempo e temperatura $[54,62]$. 


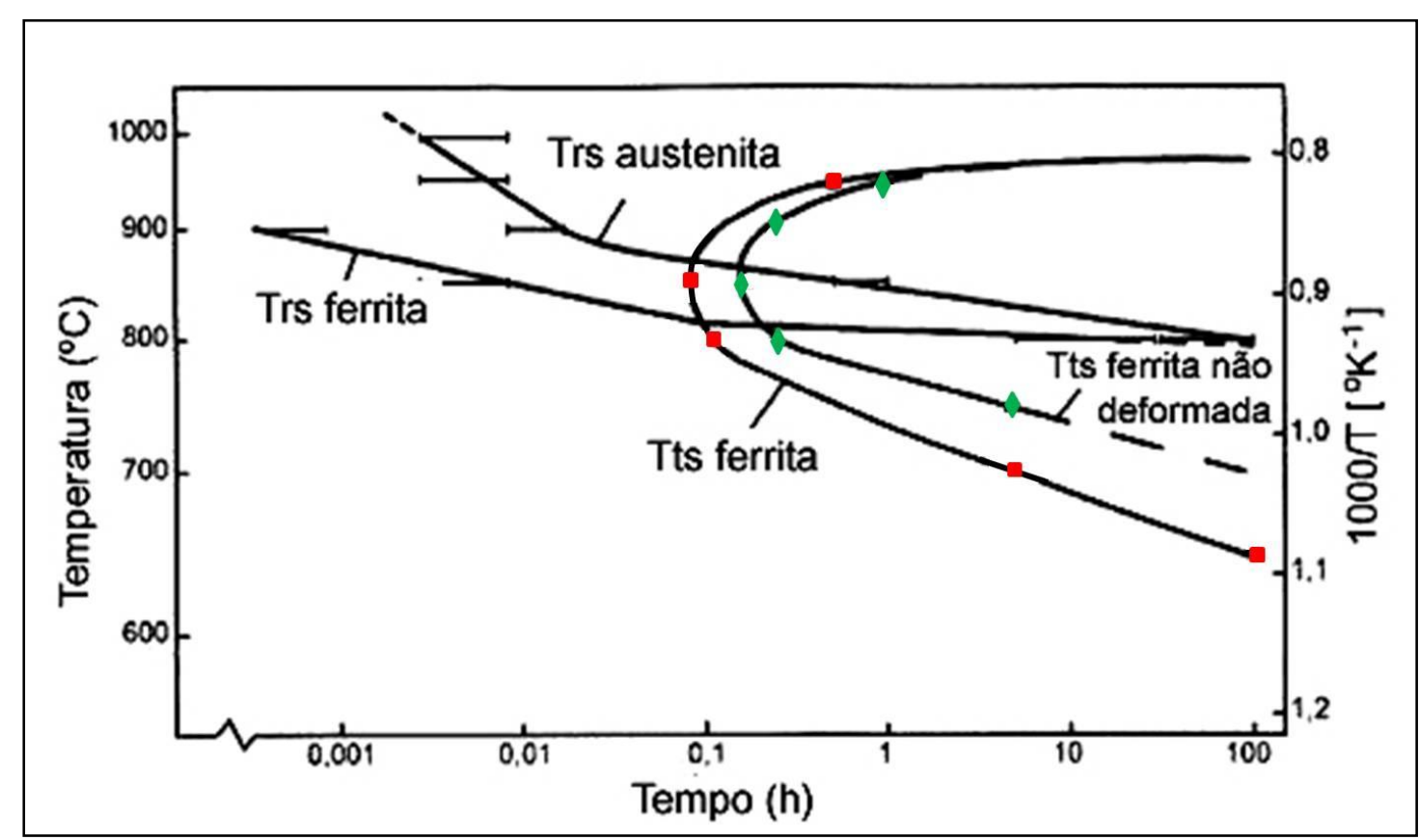

Figura 2.6 - Diagrama TTT após tratamento de solubilização (curva ) e após $20 \%$ de redução de espessura (todas as outras curvas). $r s=$ início da recristalização; ts = início da transformação eutetóide $\left(\alpha \rightarrow \sigma+\gamma_{2}\right)$ da ferrita em sigma mais austenita [54, 62].

\subsection{Crescimento de grão}

O crescimento de grão pode ser definido como um processo envolvendo a migração de contornos de grão onde o potencial termodinâmico para que isso ocorra é apenas a redução de energia superficial desses contornos. O mecanismo deste crescimento é o desaparecimento dos grãos menores, numa distribuição normal ou ainda, onde em processos de tratamentos mais longos, alguns poucos grãos crescem exageradamente com relação à distribuição normal, sendo chamado de crescimento anormal dos grãos (também conhecido como recristalização secundária) [81]. O crescimento de grão nos aços dúplex é mais lento do que em aços inoxidáveis monofásicos, pois nos aços dúplex uma fase atrapalha o crescimento da outra.

\subsection{Textura cristalográfica}

Os materiais policristalinos são constituídos por pequenos cristais chamados de grãos ou cristalitos. Cada grão, em geral, possui orientação cristalográfica que difere em dezenas de graus dos seus vizinhos. A distribuição destas orientações em média é aleatória e uma determinada orientação pode estar concentrada em maior 
ou menor grau em relação a uma referência. A esta orientação preferencial dá-se o nome de textura cristalográfica [84].

Durante a deformação à quente, a deformação plástica ocorre principalmente por deslizamento de planos cristalinos com orientações preferenciais, resultando na chamada textura de deformação. A textura final de um material depende principalmente da mudança de forma imposta durante a deformação, da temperatura na qual ocorreu a conformação, e ainda, no caso particular de pequenas deformações, da orientação inicial dos grãos antes da deformação [85]. Um mesmo aço inoxidável dúplex, por exemplo, pode apresentar diferentes orientações de textura caso as condições de laminação e recozimento sejam diferentes [86]. A textura pode levar a uma forte anisotropia das propriedades mecânicas do material [87].

A literatura publicada nas últimas décadas sobre as modificações da textura cristalográfica nos aços inoxidáveis dúplex é relativamente extensa. Uma busca por tópicos em duas importantes bases de dados (scopus e web of Science), cruzando os termos duplex stainless steel e texture apontam mais de uma centena de trabalhos relacionados à textura nos aços inoxidáveis dúplex desde a década de 1980 [9, 14, 17, 53, 88 - 218]. As principais texturas cristalográficas encontradas na austenita e ferrita dos aços inoxidáveis dúplex podem ser observadas na tabela 2.2, para um caso específico de laminação cruzada [53].

Tabela 2.2 - Principais texturas cristalográficas para a austenita e ferrita dos aços inoxidáveis dúplex em diferentes condições [53].

\begin{tabular}{lll}
\hline \multicolumn{1}{c}{ Condição } & \multicolumn{1}{c}{ Ferrita } & \multicolumn{1}{c}{ Austenita } \\
\hline Solubilizada & $(001)<110>$ & $(112)<110>;(110)<112>$; \\
Laminada a frio & $(001)<110>;(112)<110><100>$ \\
& & $(112)<110>;(110)<112>;$ \\
Recristalizada após 20\% & $(001)<110>$ & $(001)<100>$ \\
de redução* & & $(112)<110>;(110)<112>;$ \\
Recristalizada após 50\% & $(001)<110>;(112)<110>$ & $(112)<110>;(110)<112>;$ \\
de redução* & & $(001)<100>$ \\
\hline
\end{tabular}

* A textura de recristalização da austenita é mais fraca para maiores níveis de deformação, neste caso específico que é a laminação cruzada. 


\subsection{Propriedades magnéticas dos materiais}

Ímãs são materiais constituídos por polos (norte e sul) onde polos de mesmos sinais se repelem e polos de sinais contrários se atraem. Sabe-se que polos sempre ocorrem em pares de corpos magnetizados. A força de atração entre dois corpúsculos magnetizados é diretamente proporcional ao produto de suas cargas $\left(p_{1}\right.$ e $\left.p_{2}\right)$ e inversamente proporcional ao quadrado da distância (d) que os separa, conforme expresso na equação 2.8 [219]:

$F=\frac{p_{1} p_{2}}{d^{2}}$

Equação 2.8

Um polo magnético cria um campo magnético ao seu redor que age sobre outro polo próximo das extremidades. Campo magnético (linhas de fluxo), representado pela letra $\mathrm{H}$, são linhas imaginárias que representam a força e direção do campo magnético [219].

Quando existe um ângulo $\theta$ entre dois polos $p$ com uma distância $d$ entre eles e campo magnético $\mathrm{H}$ uniforme, o momento magnético é o torque que tende a colocar os ímãs em paralelo [219].

Polos magnéticos, por outro lado, representam um conceito matemático, em vez de realidade física, pois eles não podem ser separados para a medição e não estão localizados em um ponto, o que significa que a distância I entre eles é indeterminada. Embora p e I sejam quantidades incertas individualmente, seu produto é o momento magnético $\mathrm{m}$, o que pode ser medido com precisão [219].

Apesar de sua falta de precisão, o conceito de polo magnético é útil para visualizar muitas interações magnéticas, e útil na solução de problemas magnéticos. Ao considerar-se um ímã com um campo uniforme, o momento magnético dobra sua força de polo à medida que a distância $p$ é reduzida à metade. Ao limite de um íma muito curto, de momento finito, dá-se o nome de dipolo magnético [219].

Materiais ferromagnéticos são aqueles que possuem um momento magnético permanente na ausência de um campo magnético externo e manifestam magnetizações muito grandes e permanentes, ou seja, após serem submetidos a um campo magnético, eles permanecem magnetizados mesmo após a retirada do campo magnetizante. Quando um material está uniformemente magnetizado, ele 
contém um grande número de dipolos magnéticos distribuídos homogeneamente em seu volume e orientados numa única direção. A intensidade de magnetização $M$ significa a razão entre o momento magnético total $\mathrm{m}$ por unidade de volume, expresso na equação 2.9 [219, 220]:

$M=\frac{m}{V}$

Equação 2.9

As unidades são $\left(\frac{A m p \text { ére }}{\text { metro }{ }^{2}}\right)$ ou $\left(\frac{e . m . u .}{\mathrm{cm}^{3}}\right)$ ou simplemente e.m.u., sigla que significa unidade eletromagnética de momento magnético.

Dependendo da ocasião, pode ser conveniente expressar a intensidade de magnetização em unidade de massa ao invés de volume. É conhecida como magnetização específica e denotada por $\sigma$. Daí, tem-se a equação 2.10 [219, 220]:

$\sigma=\frac{m}{V \rho}=\frac{M}{\rho}$

Equação 2.10

Nesse caso, a unidade que expressa a propriedade de magnetização específica é e.m.u./g.

Quando um material ferromagnético é magnetizado, ou seja, submetido a um campo magnético, ele aumenta sua magnetização até atingir um limite, denominado saturação magnética, proporcional à fração volumétrica de fase magnética. Quando o campo magnetizante externo é retirado, e ainda o material não possua nenhum campo desmagnetizante interno, a magnetização epecífica não retorna ao valor zero, ou seja, permanece um valor de magnetização denominado remanência (quadrante positivo). Se ainda esse mesmo material é submetido a um campo desmagnetizante (sentido contrário) ele oferece uma resistência a desmagnetização, a qual é denominada coercividade (quadrante negativo). Esta propriedade está relacionada com a orientação cristalográfica do material, ou seja, estudos relacionados à textura cristalográfica podem ser conduzidos por meio desta propriedade. Continuando essa desmagnetização o material atinge um limite de saturação. Novamente, se após a saturação o campo for invertido, esse material não volta ao valor zero de magnetização nesse sentido, tendo uma remanência (no quadrante negativo). Continuando a magnetização ele sofre uma resistência a magnetizar-se nesse sentido, a coercividade (no quadrante positivo) até atingir o 
limite superior de saturação, encerrando o ciclo. Se durante um ensaio experimental esses dados forem tomados ponto a ponto, produz-se uma curva denominada histerese magnética [219, 220].

\subsection{Principais fases presentes nos aços inoxidáveis}

Para avaliar o efeito dos elementos de liga na microestrutura dos aços inoxidáveis foram desenvolvidas diferentes expressões que agrupam os elementos

de liga segundo seu efeito ferritizante (elementos alfagênicos) ou austenitizante (elementos gamagênicos), denominados respectivamente, por cromo equivalente e níquel equivalente [221 - 224]. O diagrama de Schaeffler, ilustrado na figura 2.7, é construído com essas equações e propicia uma primeira aproximação da microestrutura a ser obtida para uma determinada composição química. Dentre as várias fórmulas de $\mathrm{Cr}_{\mathrm{eq}}$ e $\mathrm{Ni}_{\mathrm{eq}}$ existentes, podem ser mencionadas a equação 2.11 e a equação 2.12 :

$\mathrm{Cr}_{\text {eq }}=\mathrm{Cr}+1,37 \mathrm{Mo}+1,5 \mathrm{Si}+2 \mathrm{Nb}+3 \mathrm{Ti}$

Equação 2.11

$\mathrm{Ni}_{\text {eq }}=\mathrm{Ni}+0,3 \mathrm{Mn}+22 \mathrm{C}+14,2 \mathrm{~N}+\mathrm{Cu}$

Equação 2.12

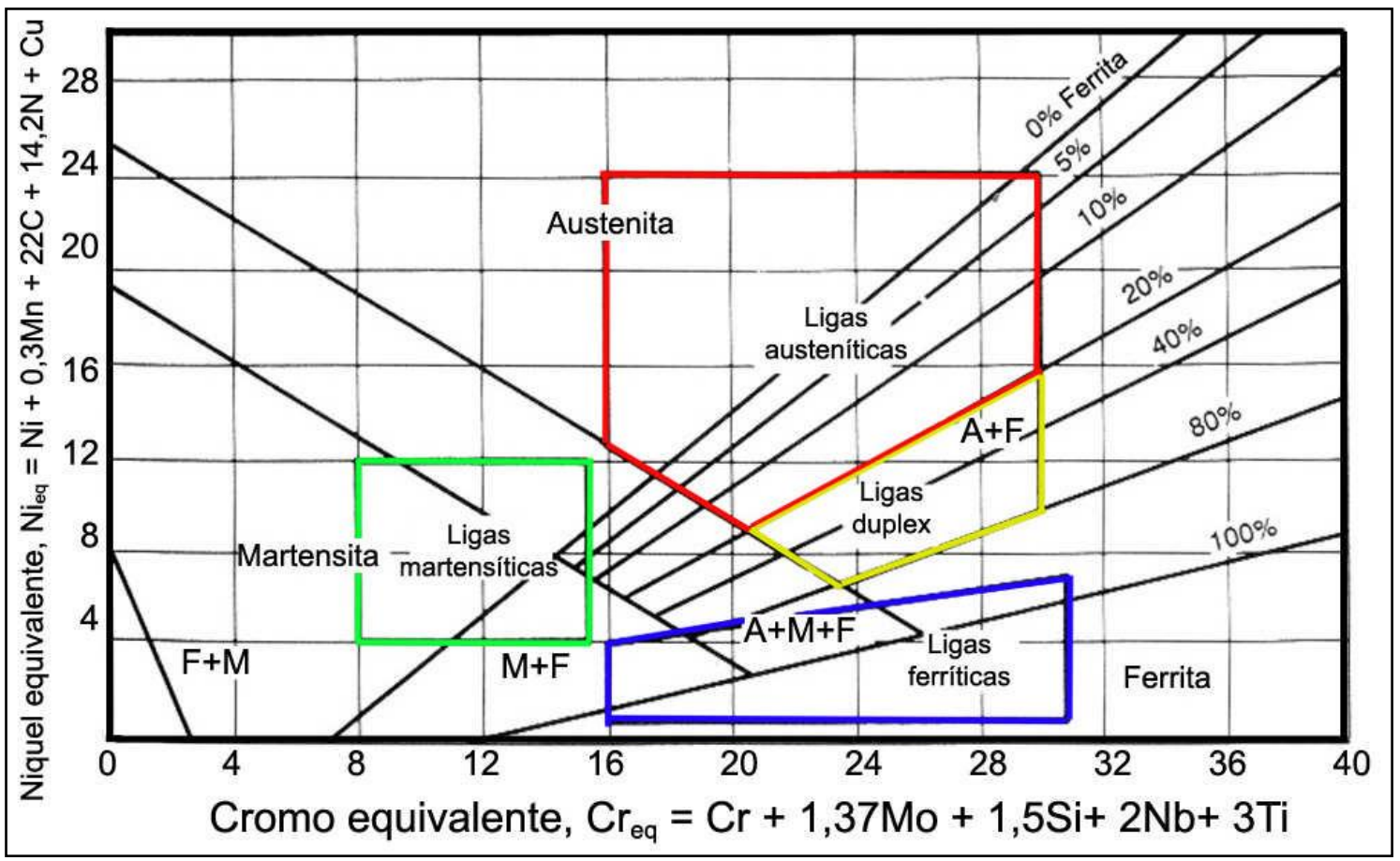

Figura 2.7 - Diagrama de Schaeffler, mostrando os campos de existência dos diversos tipos de aço 
[225].

É importante mencionar que a abordagem de Schaefler é muito útil para a previsão das microestruturas dos aços inoxidáveis no estado bruto de fundição, ou até na condição solubilizada. Vale lembrar que estes não são diagramas de equilíbrio e sim diagramas práticos.

Quando os aços inoxidáveis dúplex são expostos a temperaturas elevadas, o equilíbrio termodinâmico é alterado e o sistema tende a alcançar uma situação de menor energia, precipitando ou dissolvendo fases. Estes aços, devido à grande quantidade de elementos de liga, estão sujeitos à precipitação de inúmeras fases [39], como mostra a figura 2.8 [60]. Essas fases podem causar danos às resistências mecânica e/ou de corrosão do material.

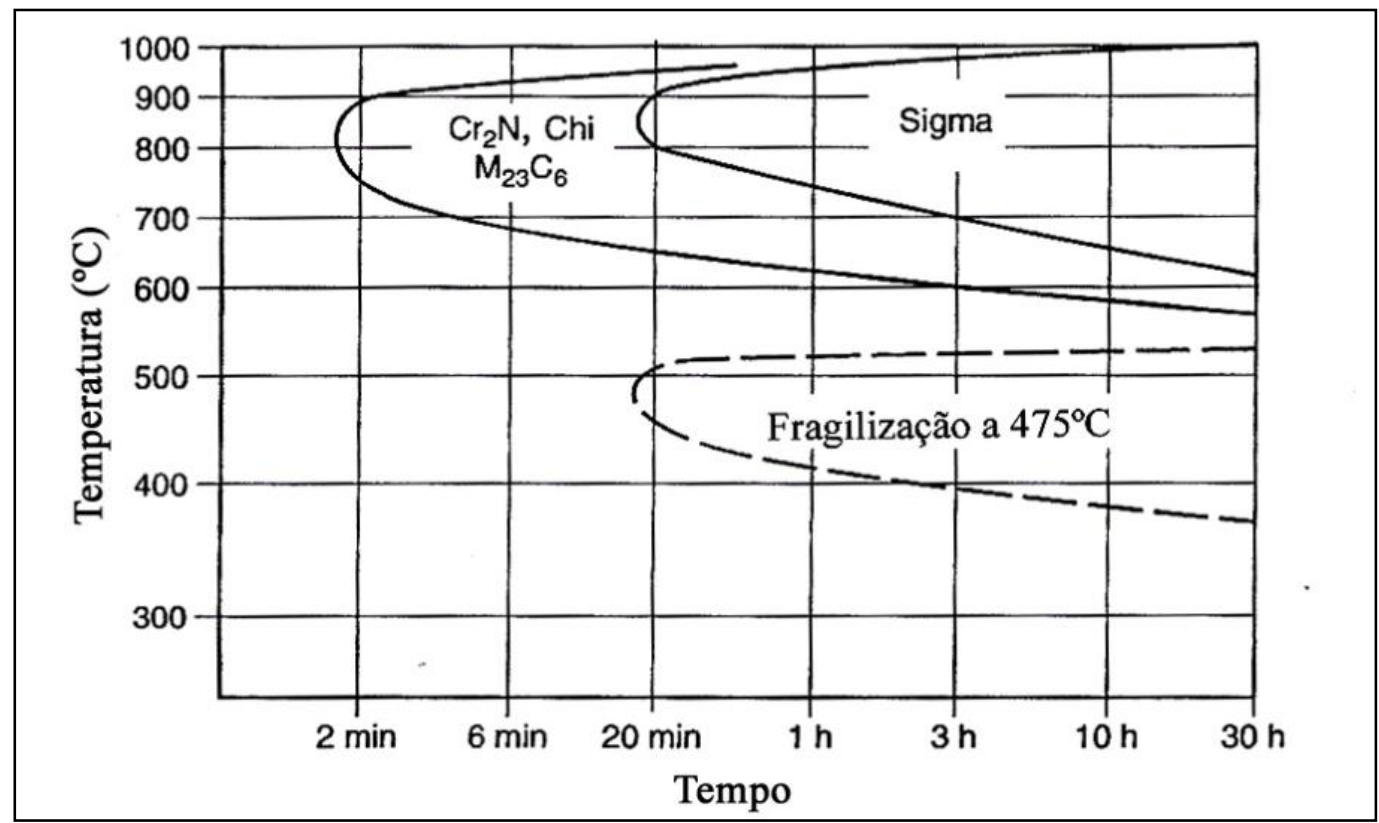

Figura 2.8 - Diagrama esquemático tempo-temperatura-transformação (TTT) tipo C, mostrando as possíveis transformações de fase [60].

\section{$2.8 \quad$ A fase sigma $(\sigma)$}

A fase sigma é ocorrente em altas temperaturas pelo rearranjo principalmente dos elementos ferro, cromo e molibdênio dentre as possíveis fases precipitáveis no aço inoxidável dúplex. Sua importância está associada à rápida cinética de precipitação e aos danos às propriedades mecânica e química que ela acarreta nos aços dúplex [226 - 228]. Os altos teores de cromo e molibdênio dos aços inoxidáveis dúplex tornam-nos susceptíveis à precipitação desta fase, caracterizada por ser um composto intermetálico duro e frágil de estrutura tetragonal 
com 30 átomos por célula unitária, responsável pela diminuição da tenacidade e que deixa a matriz empobrecida de cromo e molibdênio [60]. Uma situação acentuada é a dos aços super dúplex, que são mais sensíveis a esse tipo de precipitação pela maior proporção de cromo e molibdênio em relação aos dúplex convencionais [60, 87]. Como resultado, pode haver ocorrência da fase sigma em menores tempos e também numa maior faixa de temperatura (provocada pelo molibdênio). Ela é estável numa ampla faixa de temperatura que varia, por exemplo, de $550{ }^{\circ} \mathrm{C}$ até próximo de $1000{ }^{\circ} \mathrm{C}$, dependendo da composição química. A precipitação ocorre preferencialmente nas interfaces da ferrita/austenita, consumindo a ferrita, fato que explica a diminuição da resistência química aos arredores da mesma. Essa precipitação se dá por decomposição eutetóide de ferrita $\rightarrow$ austenita secundária + fase sigma $[48,229,230]$.

A figura 2.9 mostra uma representação esquemática de uma estrutura tetragonal de corpo centrado como a fase sigma [231].

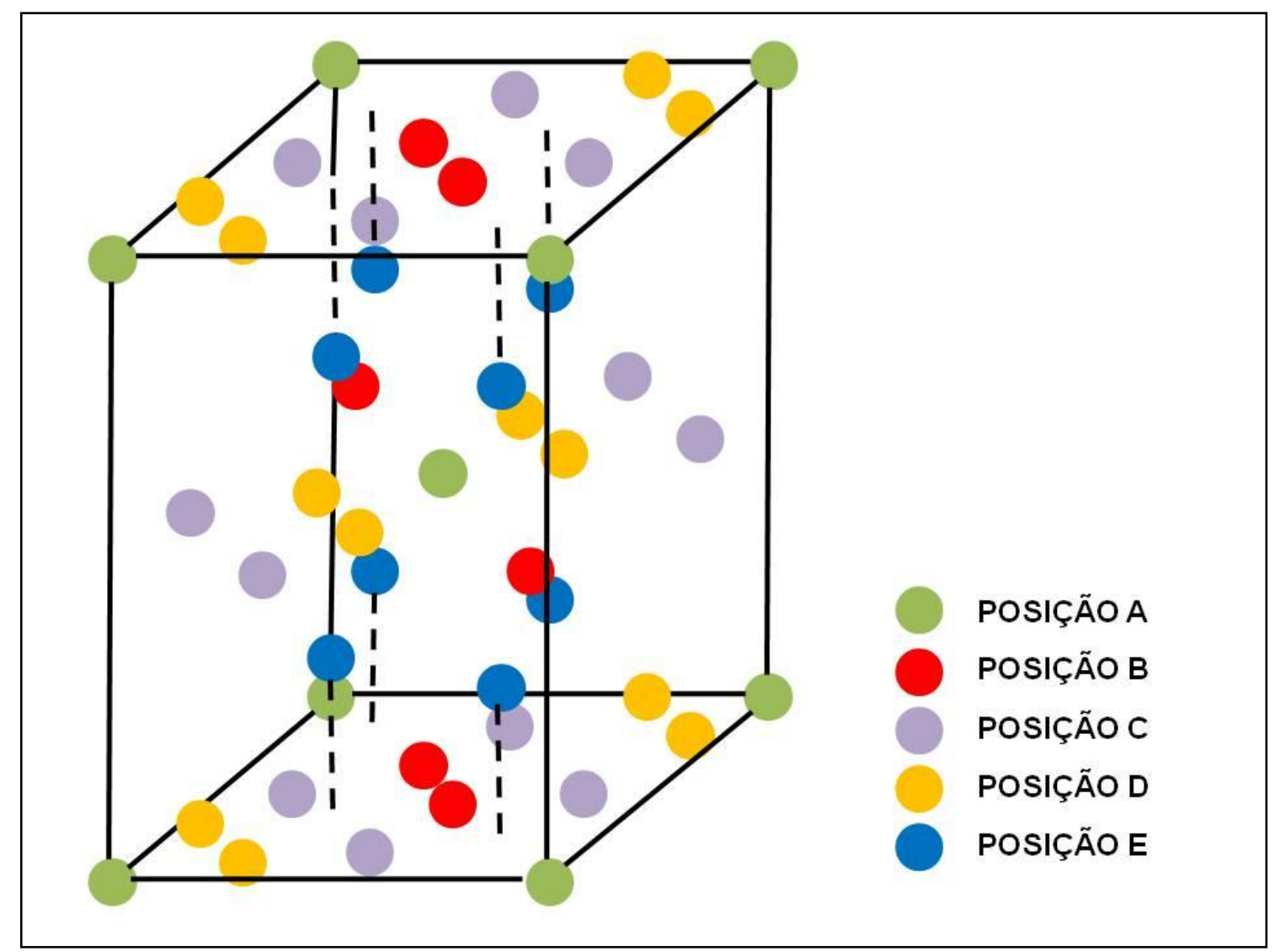

Figura 2.9 - Representação da estrutura cristalina tetragonal complexa da fase sigma com as possíveis posições que os átomos podem ocupar [231]. 
O processamento comum dos aços inoxidáveis dúplex, que é a laminação a quente, deve ser evitado entre 800 e $900^{\circ} \mathrm{C}$, faixa de temperatura em que essa fase é estável. Além da temperatura propícia para a precipitação, a laminação introduz defeitos cristalinos na estrutura dos materiais e há evidências na literatura que esses defeitos podem ser pontos preferenciais de nucleação da fase sigma, acelerando sua cinética de precipitação $[87,232,233]$.

A

figura 2.10 A ilustra por microscopia óptica e

figura 2.10 B por microscopia eletrônica de varredura, uma microestrutura de aço inoxidável super dúplex onde ocorreu a precipitação da fase sigma [234] 

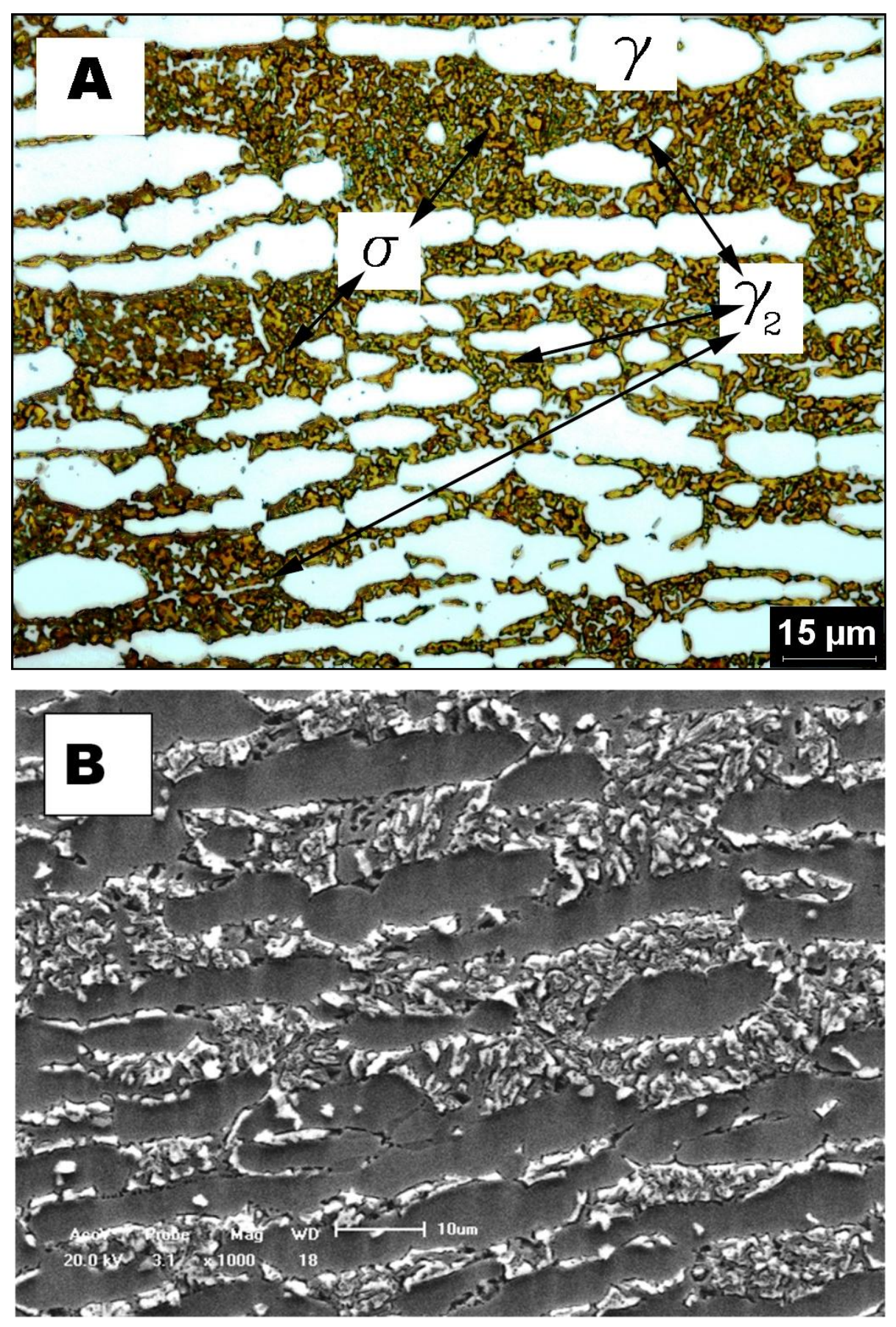

Figura 2.10 - Imagem representando a precipitação da fase sigma. A - microscopia óptica do aço inoxidável super dúplex envelhecido por 12 horas a $800 \stackrel{\circ}{\circ}$ e B - microscopia eletrônica de varredura do aço inoxidável super dúplex envelhecido por 1 hora a $800 \stackrel{\circ}{ } \mathrm{C}$ [234]. 


\subsection{Outras precipitações de fases importantes}

Outras fases importantes também podem precipitar nos aços inoxidáveis dúplex e que embora ocorram em menor quantidade, também influenciam as propriedades.

Por exemplo, embora os aços inoxidáveis dúplex trabalhados tenham carbono máximo de $0,03 \%$, praticamente todo o carbono do aço dúplex concentrase preferencialmente na austenita. A precipitação de $\mathrm{M}_{23} \mathrm{C}_{6}(\mathrm{M}=\mathrm{Cr}, \mathrm{Fe}, \mathrm{Mo}, \mathrm{Ni})$ ocorre na faixa entre 700 a $900{ }^{\circ} \mathrm{C}$, para tempos curtos de exposição (menores que 30 minutos), mas para tempos longos também ocorre precipitação entre 550 e 700 ${ }^{\circ} \mathrm{C}$ [39].

A precipitação de fase chi ocorre quase que simultaneamente com a precipitação de fase sigma, todavia em uma faixa mais estreita de temperaturas; entre 600 e $900 \stackrel{\circ}{\circ}$. Para tempos mais longos de exposição, existem evidências de que a fase qui se transforma em fase sigma [39].

A fase de Laves $\left(\mathrm{Fe}_{2} \mathrm{Mo}\right)$ precipita em pequenas quantidades para algumas horas de exposição à temperaturas entre 550 e $650^{\circ} \mathrm{C}$. a precipitação ocorre nos contornos entre ferrita/austenita e cresce consumindo parte da ferrita. Por consumir o molibdênio, reduz a resistência pitting do aço [235].

Como o nitrogênio é um elemento presente nos aços inoxidáveis dúplex como estabilizante da austenita, o efeito da temperatura na presença deste intersticial deve ser levado em consideração. Em baixas temperaturas ele está dissolvido quase que totalmente na austenita. Entretanto, em temperaturas comuns de solubilização como $1050^{\circ} \mathrm{C}$, a solubilidade dele na ferrita é aumentada. Então, no resfriamento a ferrita supersaturada precipita intergranularmente o nitreto do tipo $\mathrm{Cr}_{2} \mathrm{~N}$. Esta precipitação pode ocorrer quando o aço inoxidável dúplex é exposto isotermicamente entre 700 e $950 \stackrel{\circ}{\circ}$. Os contornos de ferrita/ferrita, contornos de subgrão da ferrita, inclusões e ao longo de discordâncias podem ser sítios preferenciais de precipitação do $\mathrm{Cr}_{2} \mathrm{~N}$ neste intervalo de temperatura [235].

Outro tipo de nitreto que é o $\mathrm{CrN}$ pode precipitar na zona afetada pelo calor durante a soldagem [235]. 


\section{MATERIAIS E MÉTODOS}

O propósito deste trabalho foi de contribuir para a melhor compreensão da deformação plástica de sistemas bifásicos, especificamente nos aços inoxidáveis dúplex. Algumas características da estrutura dos aços inoxidáveis dúplex foram investigadas, principalmente a transformação parcial da austenita em martensita induzida por deformação plástica. Para isso, foram utilizados dois aços inoxidáveis dúplex de diferentes composições químicas, comparando os aspectos do estado encruado e recozido. A caracterização inicial dos materiais como recebidos, de estrutura dúplex austenítica/ferrítica, antecedeu às duas diferentes rotas de deformação. Numa das rotas estudou-se o cavaco limado a partir do material inicial deformado por limagem. Na outra rota, estudou-se esse mesmo material inicial deformado por laminação. Um desenho esquemático pode auxiliar no entendimento da organização desta pesquisa como mostrado na figura 3.1.

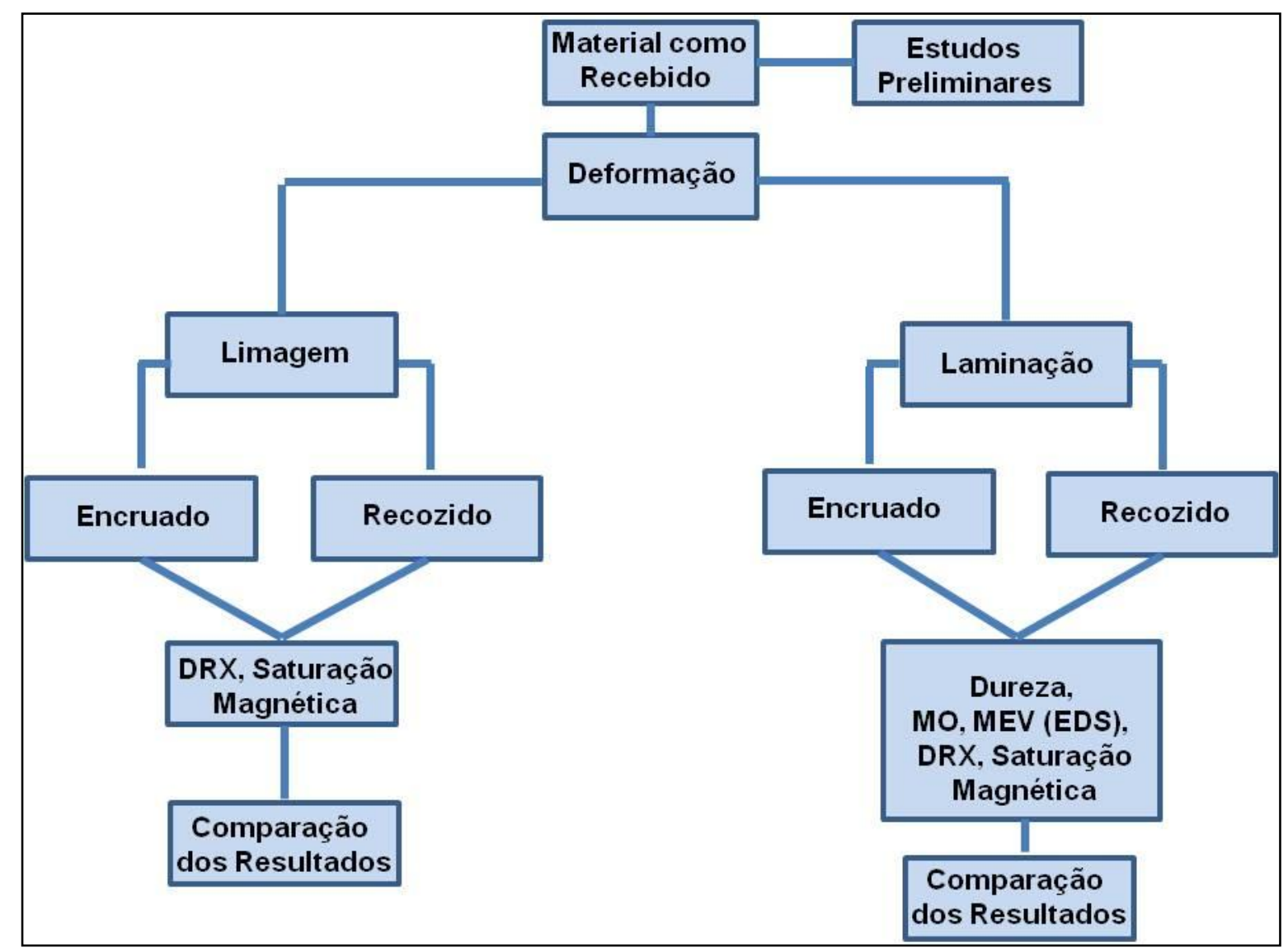

Figura 3.1 - Fluxograma organizacional dos experimentos realizados no presente trabalho. 
Os primeiros estudos de reversão de martensita induzida por deformação para austenita foram realizados nas amostras em forma de cavaco limado, iniciandose por $600{ }^{\circ} \mathrm{C}$ que a literatura sugeria. Outros tratamentos adicionais foram realizados para maior detalhamento. Descobriu-se que a reversão ocorria para os tratamentos de 600 e $650 \stackrel{\circ}{\circ}$. Por isso, nas amostras laminadas, apenas estas duas temperaturas de tratamento foram usadas, já que o foco era a reversão da martensita e não a precipitação de outras fases, como por exemplo, a fase sigma.

\subsection{Caracterização inicial dos aços inoxidáveis dúplex UNS S31803 e super dúplex UNS S32520}

Os materiais utilizados neste trabalho são os aços inoxidáveis dúplex UNS S31803 e super dúplex UNS S32520. Na tabela 3.1 e tabela 3.2 são apresentadas as composições químicas dos materiais pesquisados neste trabalho. $O$ aço inoxidável dúplex UNS S 31803 encontrava-se na forma de chapa laminada a quente nominalmente solubilizada com espessura de $8,0 \mathrm{~mm}$ e o aço inoxidável super dúplex UNS S32520 encontrava-se na forma de chapa laminada a quente nominalmente solubilizada com espessura de $5,0 \mathrm{~mm}$.

Tabela 3.1 - Composição química (em \% em massa) do aço inoxidável dúplex UNS S31803.

\begin{tabular}{cccccccccc}
\hline $\mathbf{C}$ & $\mathbf{S i}$ & $\mathbf{M n}$ & $\mathbf{P}$ & $\mathbf{S}$ & $\mathbf{C r}$ & $\mathbf{N i}$ & $\mathbf{M o}$ & $\mathbf{C u}$ & $\mathbf{N}$ \\
\hline 0,0234 & 0,278 & 1,797 & 0,0374 & 0,0010 & 22,52 & 5,54 & 3,246 & 0,148 & 0,157 \\
\hline
\end{tabular}

Tabela 3.2 - Composição química (em \% em massa) do aço inoxidável super dúplex UNS S32520.

\begin{tabular}{cccccccccc}
\hline $\mathbf{C}$ & $\mathbf{S i}$ & $\mathbf{M n}$ & $\mathbf{P}$ & $\mathbf{S}$ & $\mathbf{C r}$ & $\mathbf{N i}$ & $\mathbf{M o}$ & $\mathbf{C u}$ & $\mathbf{N}$ \\
\hline 0,0236 & 0,295 & 0,867 & 0,0464 & 0,0004 & 24,90 & 6,50 & 4,044 & 1,399 & 0,2180 \\
\hline
\end{tabular}

As amostras como recebidas dos aços foram caracterizadas usando-se as técnicas de microscopia óptica, estereologia quantitativa (medição de fração volumétrica e de tamanho de grão), microscopia eletrônica de varredura, espectroscopia de dispersão de energia, dureza Vickers (HV1), difração de raios X e refinamento matemático de Rietveld, ensaios magnéticos por ferritoscopia (permeabilidade magnética) e magnetometria (saturação magnética). A preparação metalográfica consistiu da etapa de lixamento até lixa \# 4000, seguida de polimento 
mecânico em suspensão de sílica coloidal. Para a observação em microscopia óptica as amostras foram atacadas com diversos reagentes metalográficos, dentre eles o reagente de Beraha, o qual foi usado para as determinações de metalografia quantitativa. Outro ataque usado para acentuar o contraste entre as fases foi o ataque térmico por 1 minuto em chama de gás de cozinha comum (GLP).

A quantidade de fase ferromagnética foi determinada com auxílio de um ferritoscópio (medidas de indução magnética) da marca Fisher, com limite de detecção de $0,1 \%$.

\subsection{Métodos utilizados para deformação das amostras}

O grande interesse deste trabalho é o estudo das martensitas induzidas por deformação nos aços inoxidáveis dúplex. A laminação de chapas é um método de deformação que induz forte orientação preferencial no material. Sabendo-se que a difração de raios $X$ seria uma das técnicas empregadas na quantificação de martensita induzida por deformação, decidiu-se também o uso da deformação por limagem do material. Isso porque a laminação em geral acentua orientação preferencial (textura cristalográfica) no material, dificultando a quantificação pela análise de difração de raios $X$. A limagem foi escolhida porque a produção de cavacoss por limagem introduz uma grande quantidade de defeitos cristalinos e de martensita induzida por deformação, além de diminuir os efeitos de textura na análise dos picos de raios $X$.

\subsubsection{A deformação pelo método de laminação}

As amostras de aço inoxidável dúplex foram cortadas em barras quadradas de aproximadamente $150 \times 10 \mathrm{~mm}$, que foram usinadas $1 \mathrm{~mm}$ de cada lado reduzindo sua espessura de $8 \mathrm{~mm}$ do material como recebido para $6 \mathrm{~mm}$. A redução de espessura teve o objetivo de aproximar das condições iniciais do aço inoxidável super dúplex, que por sua vez, foram cortadas em barras quadradas de aproximadamente $150 \times 10 \mathrm{~mm}$ e sua espessura original de $5 \mathrm{~mm}$. Em todas as laminações utilizou-se passos de redução com finalidade de manter o fator delta de redução menor ou igual a 1. Durante os passos de redução foi retirada uma amostra 
do aço inoxidável dúplex para várias reduções, totalizando 10 amostras de aproximadamente $10 \times 10 \mathrm{~mm}$. Da mesma forma, foi retirada uma amostra de aço inoxidável super dúplex para várias reduções, totalizando 9 amostras de aço inoxidável super dúplex.

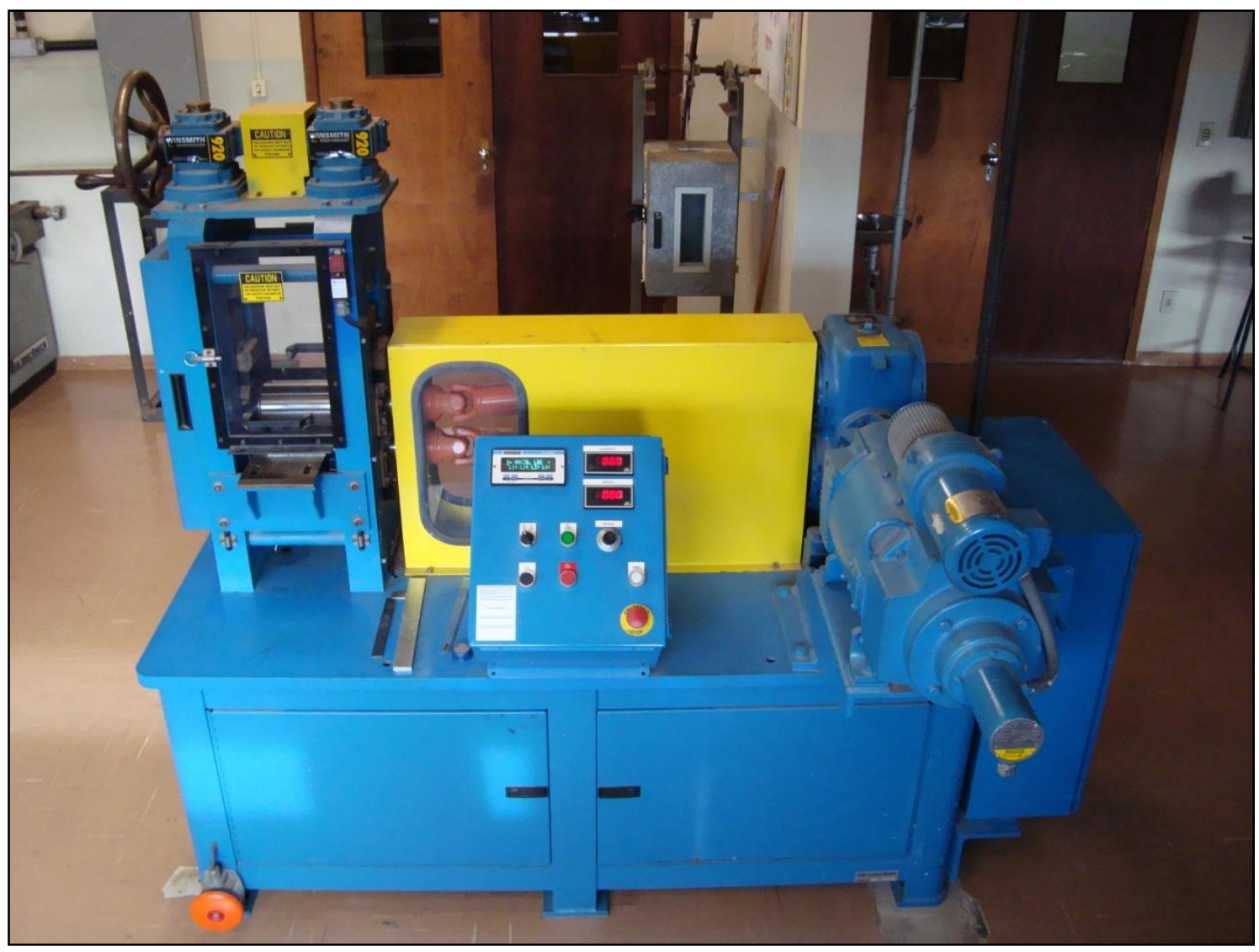

Figura 3.2 - Laminador de laboratório Fenn, instalado no Departamento de Engenharia de Materiais da Universidade Estadual de Ponta Grossa, PR.

As laminações a frio realizadas a partir do material inicial permitiram levantar uma curva de dureza em relação à redução transformada em deformação real, conforme a equação 3.1 .

$\varepsilon_{\text {real }}=L N\left(\frac{\varepsilon}{\varepsilon_{0}}\right)$

Equação 3.1

As reduções foram realizadas de forma a manter o fator delta menor que 1. Com esse cuidado, a deformação resultante embora contenha heterogeneidades, fica mais próxima possível de um processo homogêneo, ou seja, com menores variações ao longo da espessura. 
O fator delta, que leva em consideração as espessuras de entrada e saída do material ( $h_{0}$ e h, respectivamente) é defino pela equação 3.2.

fator $\Delta=\frac{h+h_{0}}{\text { arco de contato }} \quad$ Equação 3.2

O arco de contato é definido pela equação 3.3:

Arco de contato $=\sqrt{\frac{\Phi \text { do cilindro } \cdot\left(\mathrm{h}_{0}-\mathrm{h}\right)}{2}} \quad$ Equação 3.3

A taxa de deformação imposta pelo processo pode ser definida pela equação 3.4 :

$\dot{\varepsilon}=\left[\frac{\text { velocidade periférica } .}{60} \sqrt{\left.\frac{\Phi \text { do cilindro }}{1000}\right) \cdot\left[\left(\frac{h_{0}}{1000}\right)-\left(\frac{h}{1000}\right)\right]}\right] \cdot \varepsilon_{\text {real }}$

Equação 3.4

As taxas de deformação utilizadas foram normais de laminação a frio, variáveis entre 5 e $15 \mathrm{~s}^{-1}$.

Após realizadas as laminações, as amostras foram submetidas a dois tratamentos térmicos diferentes para a verificação da reversão da martensita induzida por deformação, conforme tabela 3.3.

Tabela 3.3 - Condições de tempo e temperatura de recozimento para os aços inoxidáveis dúplex UNS S31803 e UNS S32520 laminados.

Temperatura de recozimento Tempo de recozimento

$\begin{array}{ll}600 \stackrel{\circ}{C} & 1 \text { hora } \\ 650 \stackrel{\mathrm{C}}{1} & 1 \text { hora }\end{array}$

As laminações a frio (temperatura ambiente) foram realizadas em um laminador fabricado nos Estados Unidos da América, da marca Fenn e modelo 042/4 - 046. O diâmetro do cilindro laminador é de $108 \mathrm{~mm}$, a frequência do processo foi 
de 30 rotações por minuto, sendo que a velocidade periférica (linear) correspondente é de 10,17 metros por minuto. Este laminador está instalado no laboratório do Departamento de Engenharia de Materiais (DEMA) na Universidade Estadual de Ponta Grossa / PR (UEPG).

\subsubsection{A deformação pelo método de limagem dos aços}

Nesta etapa do trabalho, a amostra de cada aço foi limada para produção de um cavaco. A cominuição por limagem teve dois objetivos: a já mencionada minimização da forte textura cristalográfica habitualmente presente nos aços inoxidáveis dúplex e a introdução de grande quantidade de defeitos cristalinos e eventualmente de martensita induzida por deformação [56]. Parte do cavaco produzido por limagem foi encapsulado e tratado termicamente em temperaturas variando entre 600 e $1050 \stackrel{\circ}{\mathrm{C}}$, com duração de 1 hora. Para avaliação da reversão de martensita induzida por deformação, bem como seu efeito na recristalização do material, partes do cavaco produzido por limagem foram recozidas em diferentes condições, mantendo-se o tempo de uma hora e variando-se as temperaturas conforme indicado na tabela 3.4 :

Tabela 3.4 - Condições de tempo e temperatura de recozimento para os aços inoxidáveis dúplex UNS S31803 e UNS S32520 limados.

\begin{tabular}{|c|c|}
\hline Temperatura de recozimento & Tempo de recozimento \\
\hline $600 \stackrel{\circ}{\circ}$ & 1 hora \\
\hline $650 \stackrel{\circ}{C}$ & 1 hora \\
\hline $700 \stackrel{\circ}{C}$ & 1 hora \\
\hline $750 \stackrel{\circ}{C}$ & 1 hora \\
\hline $1050 \stackrel{\circ}{\circ}$ & 1 hora \\
\hline $650 \stackrel{\circ}{\circ} \mathrm{C}+1050 \stackrel{\circ}{ } \mathrm{C}$ & 1 hora (cada) \\
\hline
\end{tabular}

Os tratamentos térmicos foram realizados em um forno tubular de 2 KVA de potência, constituído por um tubo de mulita envolvido por resistência solenoidal de Khantal $\mathrm{A} 1$, isolado do meio externo por uma manta refratária sílico-aluminosa e com paredes externas de aço inoxidável AISI 304, instalado no laboratório do 
Departamento de Engenharia de Materiais (DEMA) na Universidade Estadual de Ponta Grossa / PR (UEPG).

\subsection{Técnicas de análise microestrutural utilizadas}

Para a caracterização microestrutural de amostras das diferentes etapas do trabalho, foram utilizadas diversas técnicas, as quais serão brevemente descritas a seguir.

\subsubsection{Microscopia óptica}

A microscopia óptica reflexiva é uma técnica muito comum e amplamente utilizada no estudo das microestruturas dos materiais metálicos. Para isso utiliza-se o equipamento microscópio óptico de luz refletida [236]. A preparação de amostras é trabalhosa, mas bastante simples, consistindo em lixamento e polimento (descritas anteriormente), com posterior ataque metalográfico, podendo ser analisadas grandes áreas da microestrutura, porém com baixa resolução, determinada pelo comprimento de onda da luz visível, que é relativamente alta $(400-800 \mathrm{~nm})$. A ampliação (aumento) da imagem é feita pela combinação de um conjunto de lentes (ocular e objetiva) que ampliam a imagem, por meio de luz refletida na superfície metálica polida e atacada. A faixa de utilização da microscopia óptica é de 1 a 1500 vezes de aumento. As observações de defeitos cristalinos como contornos de grão, contornos de macla e constituintes maiores que $0,5 \mu \mathrm{m}$ podem ser realizadas com 0 auxílio desse equipamento [236]. O microscópio usado neste trabalho é da marca Olympus, modelo BX 60M, com uma câmera digital acoplada, da marca Micrometrics, com 3 mega pixels de resolução e sinal de saída ligado em um computador controlado pelo programa Micrometrics SE Premium. O equipamento está instalado no laboratório de metalografia Hubertus Colpaert, do Departamento de Engenharia Metalúrgica e de Materiais da Escola Politécnica da Universidade de São Paulo (EPUSP). 


\subsubsection{Estereologia (fração volumétrica e determinação de tamanho de grão)}

Para a determinação da proporção (fração volumétrica) de fases presentes nos materiais, usou-se a metalografia quantitativa, ou simplesmente estereologia. $O$ procedimento utilizado foi o método das malhas, baseado na norma ASTM E 562 [237]. Esta metodologia consiste basicamente em escolher imagens de regiões representativas da amostra. Sobre essa imagem, desenha-se uma malha de linhas horizontais paralelas cortadas por linhas verticais paralelas, em que cada ponto em que se cruzam (nós) esteja igualmente espaçado do nó vizinho, formando um quadrado. Seguindo a recomendação da norma, a ampliação foi escolhida de modo a evitar que um número elevado (mais de dois) incidissem sobre a região que se desejava contar.

Para a determinação do tamanho de grão em casos de microestruturas orientadas, no presente caso grãos não equiaxiais em material bifásico, utilizou-se o método dos interceptos em direções aleatórias, determinando-se assim o número de grãos por unidade de comprimento $\left(\mathrm{N}_{\mathrm{L}}\right)$. Esta metodologia é baseada na norma ASTM E 112 [236, 238].

O método foi aplicado em cada uma das superfícies [longitudinal (I), transversal (t) e normal (n) à laminação] e o número de grãos por unidade de comprimento médio ( $\left.\mathrm{N}_{\text {médio }}\right)$ foi determinado pela equação 3.5 [238]:

$\boldsymbol{N}_{\text {médio }}=\sqrt{N_{L(l)} N_{L(t)} N_{L(n)}}$

Equação 3.5

Tendo-se o $\mathrm{N}_{\text {médio, }}$ o diâmetro médio de grão é estimado pela equação 3.6 [238]:

$D_{m e ́ d i o ~}=\frac{1}{\boldsymbol{N}_{\text {médio }}}$

Equação 3.6

\subsubsection{Microscopia eletrônica de varredura}

É atualmente uma técnica muito comum, complementar à microscopia óptica, que apresenta excelente profundidade de foco. A faixa mais utilizada de 
ampliação é de 10 a 20000 vezes de aumento. A preparação da amostra também é bastante simples, também consistindo em lixamento e polimento. No seu funcionamento, os elétrons são acelerados numa coluna por tensões de 1 a $40 \mathrm{KV}$, através de lentes magnéticas atingindo a superfície da amostra. O feixe de elétrons incidido passa por bobinas de varredura, interage com a amostra e os sinais são detectados por dispositivos do equipamento. A corrente que passa pelas bobinas de varredura sincronizada com as bobinas de deflexão de um tubo de raios catódicos produz uma imagem aumentada. Esses sinais são amplificados e reproduzidos em uma tela de monitor. Para análise da microestrutura podem ser usados os elétrons secundários (contraste de relevo) ou retroespalhados (contraste de massa ou número atômico) [236].

Já a análise de dispersão de energia é um acessório frequentemente encontrado nos microscópios eletrônicos de varredura em que os raios $X$ emitidos da microrregião analisada da amostra, têm suas energias determinadas por detectores do estado sólido do tipo silício dopado com lítio [236]. Ao determinar-se experimentalmente sua energia, determina-se o comprimento de onda $(\lambda)$ pela equação 3.7 [236].

$\lambda(\AA)=\frac{12,4}{\Delta \mathrm{E}}$

Equação 3.7

Determinando-se o comprimento de onda $(\lambda)$ dos raios $X$ característicos é possível identificar os átomos que os emitiram, sendo que a intensidade é proporcional à concentração. Desta maneira, numa microestrutura bifásica, como é o caso dos aços inoxidáveis dúplex, a técnica de análise de dispersão de energia auxilia no estudo do coeficiente de partição dos elementos químicos entre as fases ferrita e austenita. Além disso, a partir da composição química da austenita é possível avaliar a sua energia de defeito de empilhamento (EDE) e a sua propensão à formação de martensita induzida por deformação. A energia de defeito de empilhamento da austenita do aço UNS S31803 foi calculada com auxílio da equação 3.8, proposta por Schramm e Reed [239] para aços inoxidáveis austeníticos, apresentada em seguida:

$\operatorname{EDE}\left(\mathrm{mJ} / \mathrm{m}^{2}\right)=-53+6,2(\% \mathrm{Ni})+0,7(\% \mathrm{Cr})+3,2(\% \mathrm{Mn})+9,3(\% \mathrm{Mo})$ 
O microscópio eletrônico de varredura (MEV) utilizado neste trabalho é da marca Philips, modelo XL 30, controlado pelo programa computacional Microscope control Mctrl. $\mathrm{O}$ acessório de análise de dispersão de energia acoplado ao MEV é da marca EDAX, modelo NEW XL 30 132-10, controlado pelo programa computacional EDAX Genesis 4000. O equipamento está instalado no laboratório de microscopia eletrônica de varredura, do departamento de Engenharia Metalúrgica e de Materiais da Escola Politécnica da Universidade de São Paulo (EPUSP). Também foi utilizado o equipamento da marca FEl, modelo Quanta 600 - FEG, com sistema de microanálise por dispersão de energia, instalado no LCT, do departamento de Engenharia de Minas e Energia da Escola Politécnica da Universidade de São Paulo (EPUSP).

\subsubsection{Distribuição granulométrica das partículas de cavaco obtidas por limagem}

A distribuição granulométrica das partículas de cavaco produzido por limagem foi determinada pelo uso da técnica de espalhamento de raios laser de baixo ângulo. As medidas foram realizadas por um equipamento da marca Malvern, modelo Mastersize 2000, instalado no Laboratório de Caracterização Tecnológica (LCT) do Departamento de Engenharia de Minas e de Petróleo da Universidade de São Paulo (USP).

\subsubsection{Difração de raios $\mathrm{X}$ e refinamento matemático de Rietveld}

Quando um feixe monocromático de raios $\mathrm{X}$, com comprimento de onda $\lambda$, incidem num ângulo $\theta$ num conjunto de planos cristalinos com espaçamento $d$, ocorrerá a difração se a distância extra percorrida por cada feixe for um múltiplo inteiro de $\lambda$, seguindo a lei de Bragg, conforme equação 3.9 [236,240]:

$n \lambda=2 d \operatorname{sen} \theta$

Equação 3.9

As direções nas quais ocorre a difração são determinadas pela geometria do reticulado. Os espaçamentos entre os planos ( $\mathrm{h} \mathrm{k} \mathrm{l)} \mathrm{estão} \mathrm{relacionados} \mathrm{com} \mathrm{os}$ 
parâmetros de rede e ângulos do reticulado. Para sistemas cúbicos é válida a equação $3.10[236,240]$ :

$\frac{1}{\mathrm{~d}^{2}}=\frac{\mathrm{h}^{2}+\mathrm{k}^{2}+\mathrm{l}^{2}}{\mathrm{a}^{2}}$

Equação 3.10

Num cristal livre de deformações, o resultado da difração, respeitando a lei de Bragg, é um pico bem definido. Já em um material deformado, campos de compressão fazem com que haja o aumento do ângulo $2 \theta$, enquanto campos de tração fazem com que diminua o ângulo $2 \theta$ (respeitando a equação 3.9). Devido à presença desses campos, ocorre a diminuição da intensidade e o alargamento dos picos, conforme a figura 3.3 [240].

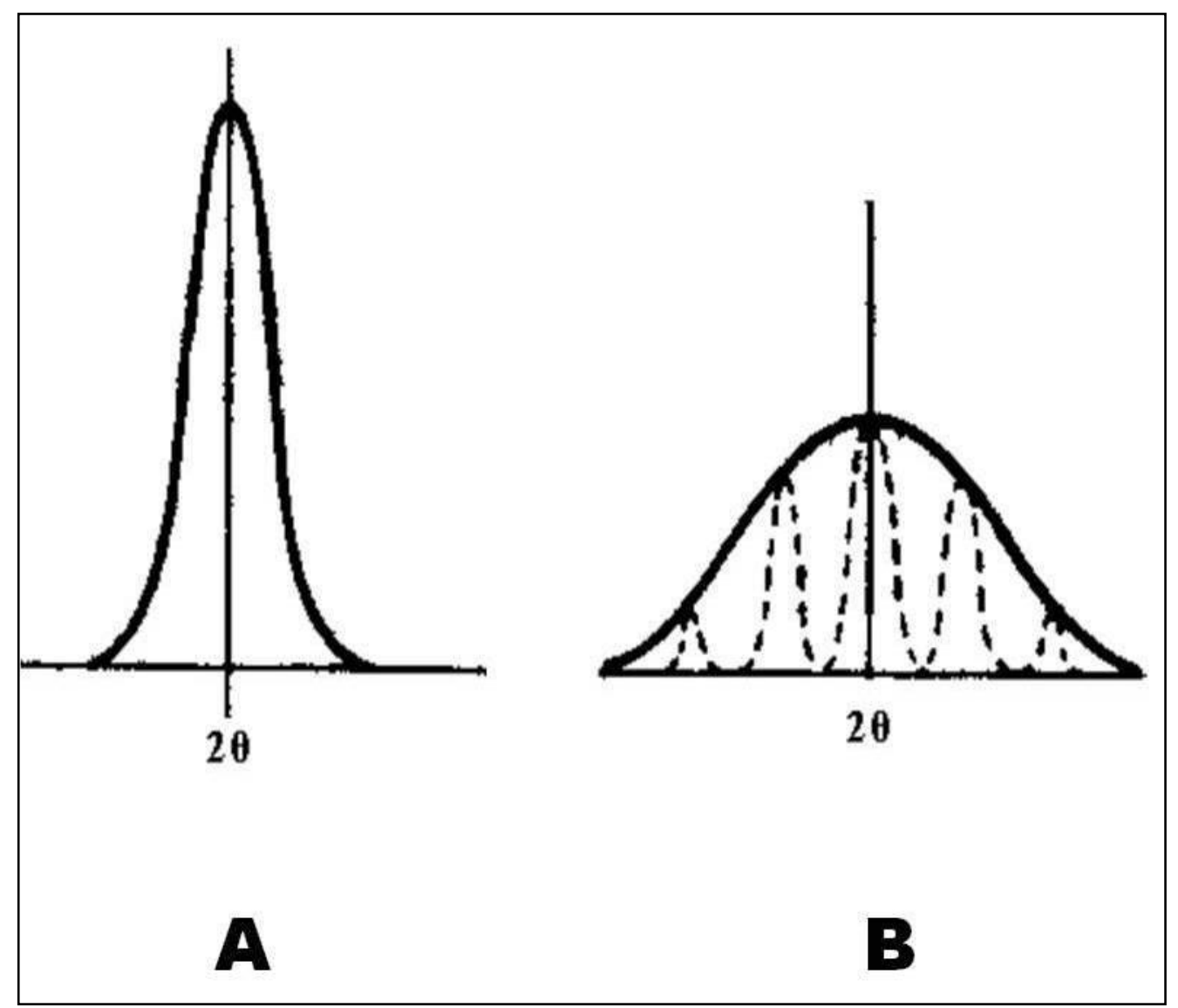

Figura 3.3 - Esquema representando picos de difração de raios X. A - representação dos picos de um cristal livre de deformações. B - representação dos picos de cristais deformados [240]. 
Uma representação esquemática de um cristal real mostra que ele é constituído de diversos blocos justapostos contendo um pequeno desalinhamento de um em relação ao outro, conforme pode ser observado na figura 3.4 [240].

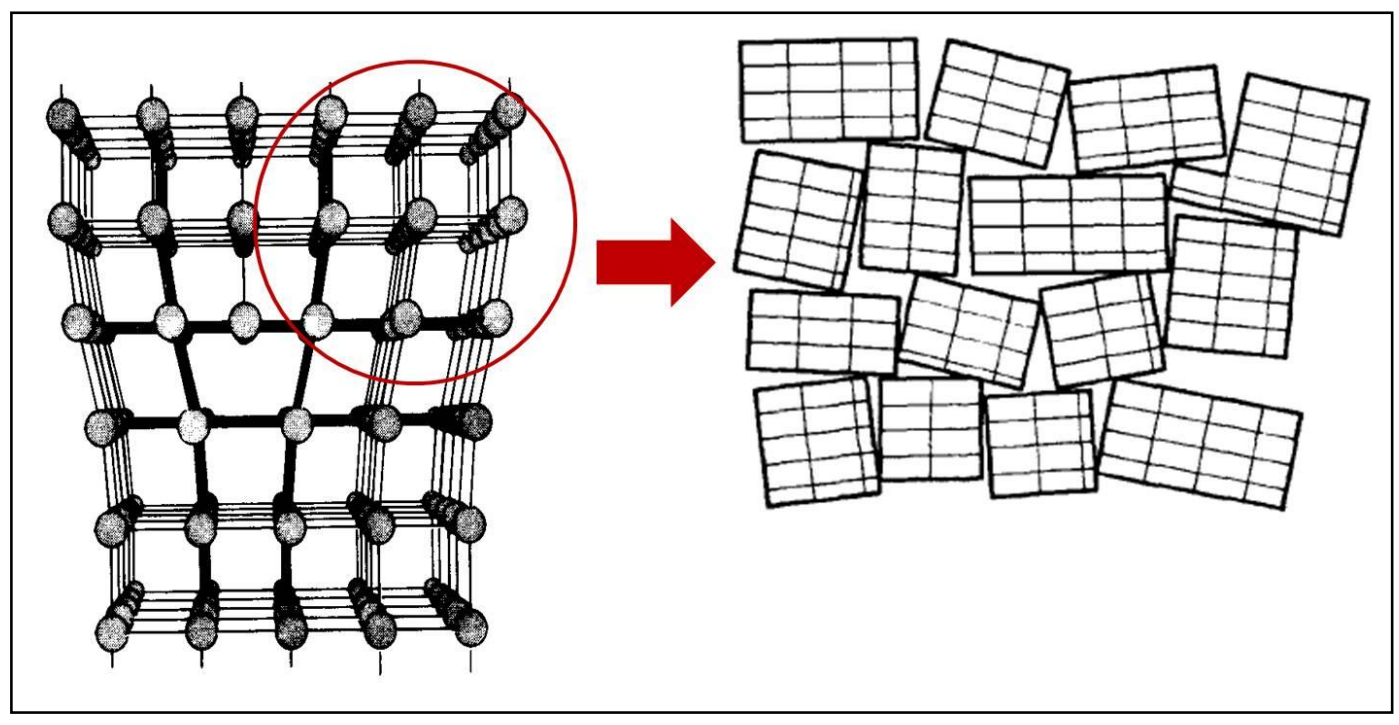

Figura 3.4 - Ilustração esquemática da estrutura de blocos, representando um cristal real [240].

O nome de cristalito é dado a cada um desses pequenos blocos individuais [241, 242]. Cristalito também pode ser definido como um conjunto de células sistematicamente agrupadas para formar um domínio coerente de difração [242]. Cada partícula de um material policristalino é constituída por inúmeros cristalitos, justapostos uns aos outros com diferentes orientações. Em metalurgia, outro termo muito comum usado para designar esses blocos (ou cristalitos) é subgrão, sendo e que a região entre eles, são as paredes constituídas de discordâncias [240]. Tanto o tamanho de cristalitos quanto as microdeformações residuais são responsáveis pelo alargamento dos picos de difração [240 - 243].

O refinamento matemático de Rietveld foi utilizado como ferramenta de trabalho nesta tese. Resumidamente, ele está baseado em integrações matemáticas das curvas de difração. Os ruídos e desvios na curva experimental foram integrados com o auxílio de um software (GSAS) e expressos numa linha fina onde o erro experimental é calculado pelo método estatístico do $\mathrm{X}^{2}\left(\mathrm{Chi}^{2}\right)$. Quanto mais próximo do valor 0, melhor é a precisão dos cálculos de refinamento [244, 245].

$O$ equipamento utilizado neste trabalho foi o difratômetro de raios $X$ da marca Rigaku, com radiação Cuka, instalado no Centro de Ciências e Tecnologia 
em Materiais do Instituto de Pesquisas Energéticas e Nucleares (CCTM - IPEN) São Paulo.

\subsubsection{A determinação das microdeformações residuais e tamanho de cristalitos}

Experimentalmente, após a coleta dos dados de difração, efetuou-se um refinamento matemático dos perfis de difração pelo método de Rietveld [244] com o auxílio do programa computacional GSAS [245]. Estas análises permitiram as determinações das quantidades de fases, das microdeformações residuais, dos tamanhos de cristalitos e dos parâmetros de reticulado. Na metodologia de análise do alargamento dos picos de difração, assumiu-se que o alargamento total possui duas componentes: tamanho de cristalitos e microdeformações residuais, sendo que cada uma pode ser identificada separadamente. $\mathrm{O}$ alargamento do pico, resultante do efeito da microdeformação $(\Delta(2 \theta)$ s), pode ser expresso pela equação 3.11 [240 - 243]. Na referência 240 esse termo é chamado de microtensão residual (que deveria ter unidade expressa em $\mathrm{MPa}$, por exemplo), porém, é um termo adimensional (sem unidades) que nas referências 241 - 243 é chamado de microdeformação residual, o qual será adotado neste trabalho.

$\Delta(2 \theta) s=2 \varepsilon \tan \theta$

Equação 3.11 onde $\varepsilon$ é a microdeformação residual. A componente do alargamento originada dos pequenos cristalitos, $\Delta(2 \theta)$ c, pode ser expressa pela equação de Scherrer, a equação 3.12 [240 - 243]. Nota-se que a referência 240 adota o termo tamanho de cristais e as referências 241 - 243 adotam o termo tamanho de cristalito, o qual foi escolhido neste trabalho.

$\Delta(2 \theta) \mathrm{c}=0,9 \lambda / \mathrm{D} \cos \theta$

Equação 3.12

O termo $\lambda$ é o comprimento de onda da radiação e $D$ é o tamanho do cristalito.

Então o alargamento total é a soma das duas componentes, como apresentado na equação 3.13 [240 - 243]: 
$\Delta(2 \theta)=\Delta(2 \theta) s+\Delta(2 \theta) c=2 \varepsilon \tan \theta+0,9 \lambda / D \cos \theta$

Equação 3.13

Portanto, todos os termos podem ser expressos pela Equação 3.14 [240 243].

$\Delta(2 \theta) \cos \theta=2 \varepsilon \operatorname{sen} \theta+0,9 \lambda / D$

Equação 3.14

A representação gráfica dessa metodologia pode ser ilustrada pela figura 3.5:

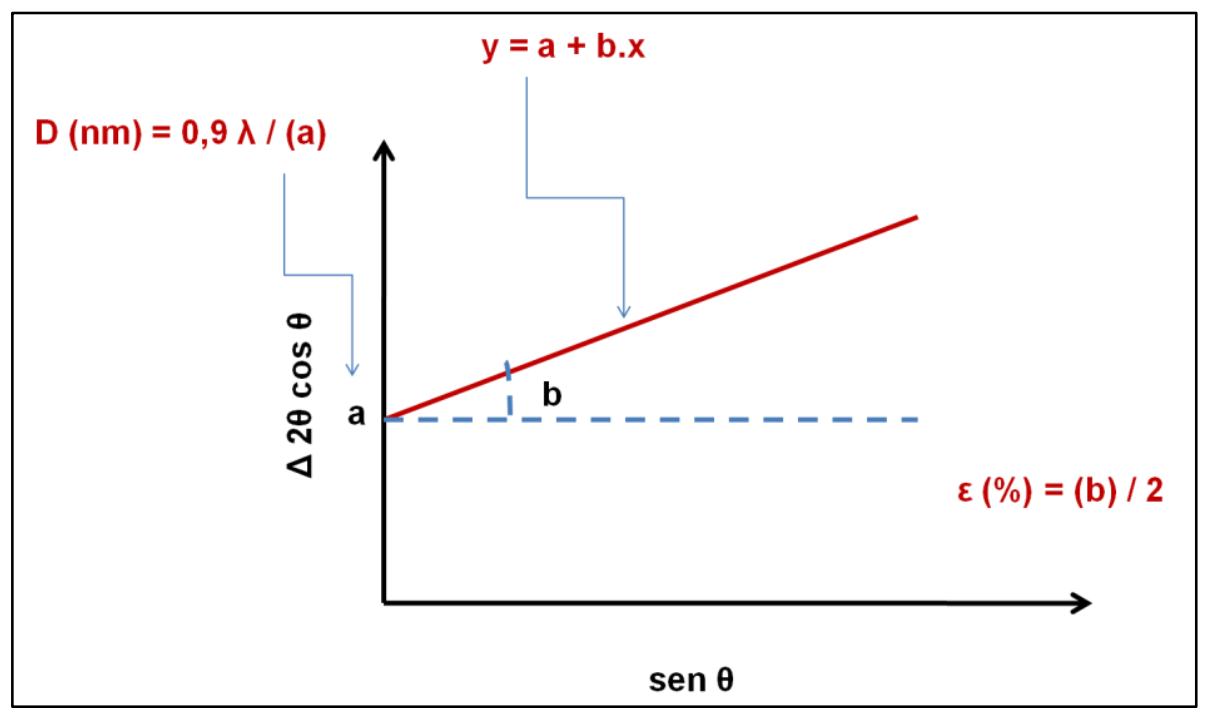

Figura 3.5 - Esquema ilustrando a metodologia de determinação da microdeformação residual e tamanho de cristalitos.

\subsubsection{A determinação dos parâmetros de rede}

Após a obtenção das figuras de difração, o ângulo $2 \theta$ de cada pico fica identificado, bem como, suas relações trigonométricas de seno e cosseno. Combinando-se a equação 3.9 com a equação 3.10 , o parâmetro de rede pode ser calculado para cada pico. Então, a partir daí foi possível o cálculo de correção dos parâmetros de rede utilizando-se dois métodos de extrapolação [236]:

$\checkmark \quad$ Método do $\cos ^{2} \theta$;

$\checkmark \quad$ Método do $\cos ^{2} \theta / \operatorname{sen} \theta$. 
No caso do parâmetro de rede da austenita, também foi possível a comparação com o valor calculado pela fórmula proposta por Dyson e Holmes [246] baseada em composição química, conforme equação 3.15 .

$$
\begin{aligned}
& \mathrm{a}_{0}( \pm 0,0016)=3,5780+0,0330 \mathrm{C}+0,00095 \mathrm{Mn}( \pm 0,0110) \\
& ( \pm 0,00015)-0,0002 \mathrm{Ni}+0,0006 \mathrm{Cr}+0,0220 \mathrm{~N}( \pm \\
& 0,00004)( \pm 0,0003)( \pm 0,0034)+0,0056 \mathrm{Al}-0,0004 \mathrm{Co}+ \\
& 0,0015 \mathrm{Cu}( \pm 0,0007)( \pm 0,0001)( \pm 0,0005)+0,0031 \mathrm{Mo}+ \\
& 0,0051 \mathrm{Nb}+0,0039 \mathrm{Ti}( \pm 0,0004)( \pm 0,0012)( \pm 0,0009)+ \\
& 0,0018 \mathrm{~V}+0,0018 \mathrm{~W}( \pm 0,0004)( \pm 0,0003)
\end{aligned}
$$

\subsubsection{Estudo das curvas de dureza das amostras laminadas}

As amostras laminadas nas diversas condições de redução supracitadas foram cortadas em 3 tiras menores para analisar cada face (longitudinal, superficial e transversal), embutidas e preparadas metalograficamente até pasta diamantada de 1 $\mu \mathrm{m}$, conforme recomendação da norma ASTM E 384 (medidas de dureza). As medidas de dureza foram realizadas num equipamento de testes de microdureza Vickers da marca Leica, modelo VMHT MOT, com aplicação da carga de $1 \mathrm{Kg}$ por 15 segundos. Tal equipamento (vide figura 3.6) está instalado no laboratório do Departamento de Engenharia de Materiais (DEMA) na Universidade Estadual de Ponta Grossa /PR (UEPG). Cada uma das três faces de cada condição de laminação foi ensaiada por 15 vezes e os resultados expressos por meio de gráficos e desvios estatísticos. 


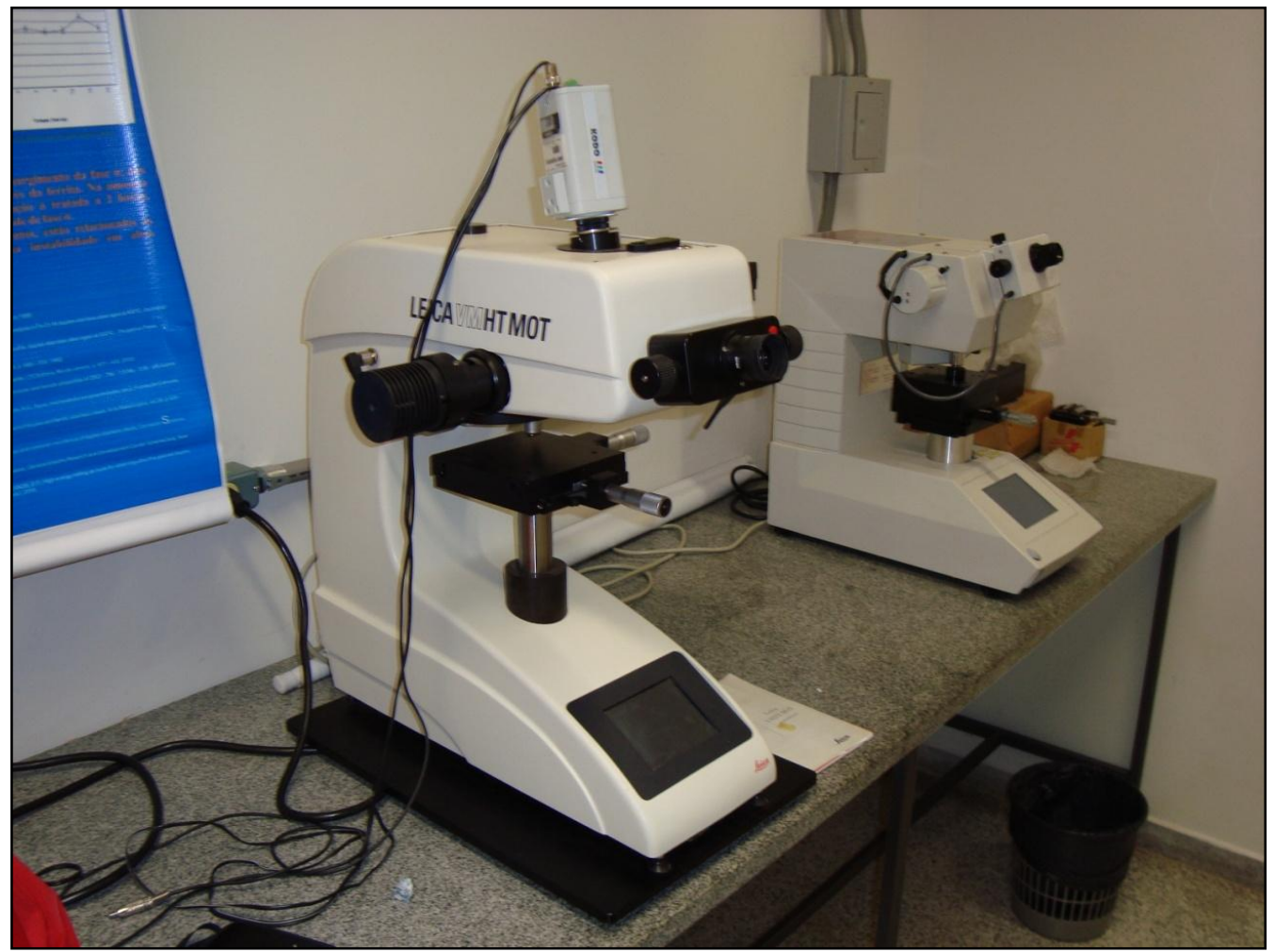

Figura 3.6 - Microdurômetro Leica, instalado no Departamento de Engenharia de Materiais na Universidade Estadual de Ponta Grossa, PR.

\subsubsection{Ensaios magnéticos do material}

Sabe-se que os materiais metálicos, inclusive os de estrutura cúbica pesquisados nesta tese podem apresentar anisotropia magnética, ou seja, diferença de comportamento nos eixos de fácil, média e difícil magnetização. Por exemplo, esta propriedade de anisotropia pode influenciar na investigação de fração volumétrica de martensita induzida por deformação em chapas laminadas, utilizando o ferritoscópio, devido às mudanças na textura imposta pela deformação. Porém, em ensaios de histerese magnética, a textura cristalográfica pode influenciar apenas no campo coercivo do material. Por essa razão, o estudo de formação de martensita induzida por deformação pode ser conduzido por essa técnica, visto que, a saturação magnética é influenciada apenas pela fração volumétrica de material magnético. Uma solução para este estudo é o uso do magnetômetro de amostra vibrante, que será descrito em seguida.

Em resumo, os ensaios magnéticos obtidos neste trabalho foram conduzidos pela utilização de dois tipos de equipamentos, um deles baseado em permeabilidade 
magnética (ferritoscópio) e outro em saturação magnética (magnetômetro de amostra vibrante).

\subsubsection{Medidas magnéticas por meio de ferritoscópio}

O ferritoscópio é um equipamento que possui uma resistência que gera um campo magnético, o qual interage com as componentes magnéticas da amostra, no caso dos aços dúplex, pode ser tanto a ferrita como martensitas alfa linha (cúbica de corpo centrado, ferromagnética) induzidas por deformação na austenita. Essa interação faz com que ocorram mudanças no campo magnético detectadas por uma resistência secundária e as quantidades de fase magnética são indicadas por um visor eletrônico. Foram feitas 10 medidas por face de cada amostra.

O ferritoscópio portátil usado neste trabalho é da marca Helmut Fischer, modelo MP 3B.

\subsubsection{Medidas magnéticas por meio de magnetômetro de amostra vibrante}

Um equipamento que é capaz de medir as propriedades de materiais magnéticos é o magnetômetro de amostra vibrante, no qual a amostra é posta a vibrar em um campo magnético e são produzidas curvas de histerese magnética. Sensores são colocados próximos à amostra de maneira a captar qualquer campo produzido por ela. O campo magnético deve ser aplicado de zero até um valor correspondente à saturação do material que está sendo ensaiado. Sinais captados e os dados são processados eletronicamente por meio de computação. A amostra deve estar preferencialmente na forma de discos ou cavaco. Para que a magnetização específica seja levada em consideração uma balança analítica de boa precisão deve ser utilizada no procedimento.

O equipamento utilizado neste trabalho é um magnetômetro de amostra vibrante da marca Lake Shore. Este equipamento está instalado no Laboratório de Materiais Magnéticos, do Instituto de Ciências Exatas (ICE) da Universidade Federal de Itajubá / MG (UNIFEI) e é ilustrado na

figura 3.7 . 


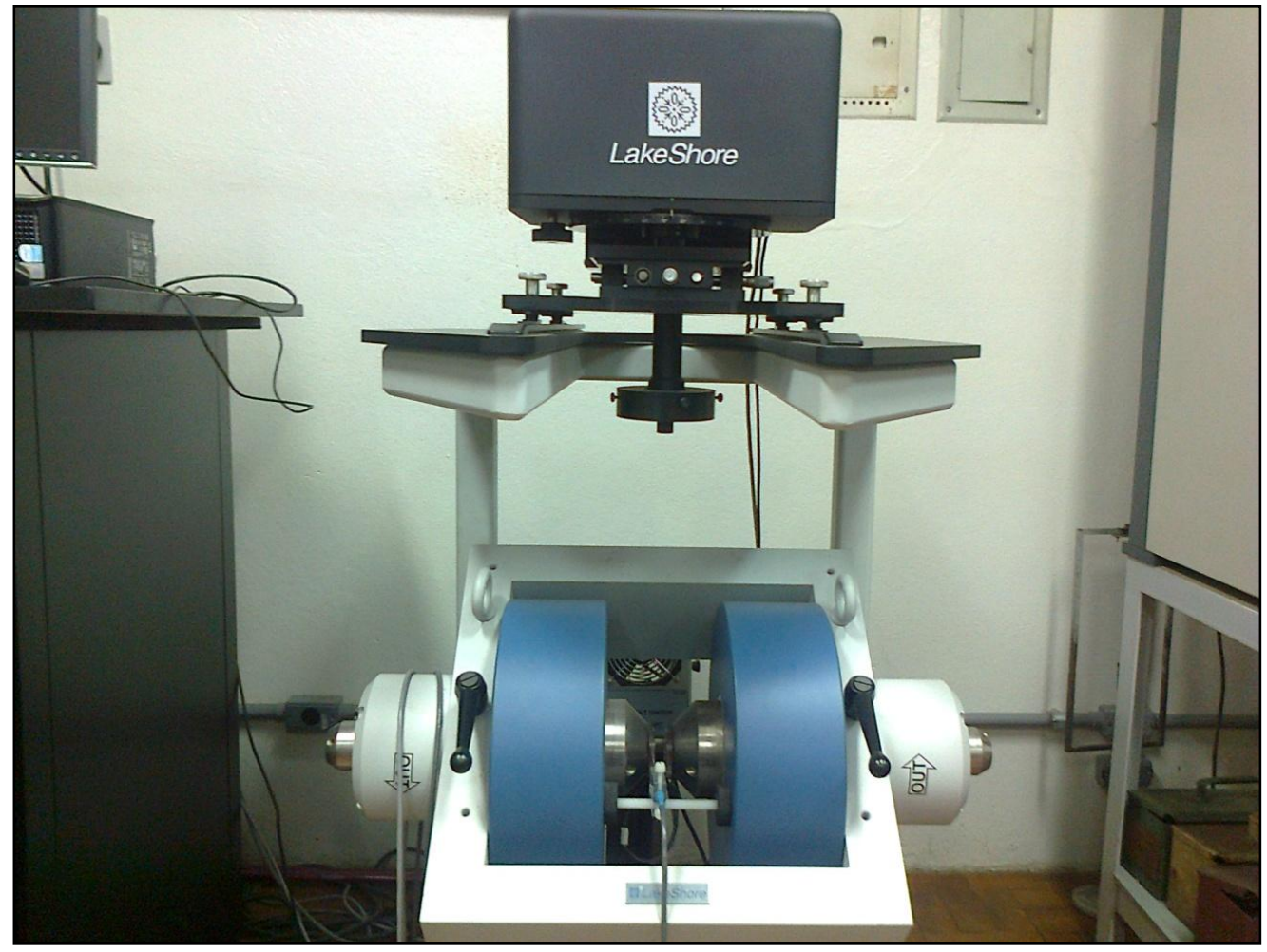

Figura 3.7 - Magnetômetro de amostra vibrante instalado no Laboratório de Materiais Magnéticos, do Instituto de Ciências Exatas (ICE) da Universidade Federal de Itajubá, MG (UNIFEI). 


\section{RESULTADOS E DISCUSSÕES}

\subsection{Resultados iniciais da amostra como recebida (nominalmente solubilizada)}

Inicialmente foram determinadas as quantidades das duas fases (ferrita e austenita) presentes na chapa no estado inicial, estado qual é nominalmente solubilizado. Foram utilizados dois métodos: estereologia (metalografia quantitativa) e ferritoscopia. Foram feitas determinações nas três faces ou superfícies, denominadas: longitudinal; transversal e superficial (superfície de laminação). O método de difração de raios $X$ foi descartado devido à presença de forte textura cristalográfica nas chapas. A partir dos resultados de microscopia óptica e estereologia quantitativa, complementarmente, determinou-se o tamanho de grão conforme técnica descrita no capítulo anterior. Tais procedimentos foram realizados para ambos os aços (dúplex e super dúplex). A tabela 4.1 apresenta um resumo da fração volumétrica determinada por estereologia quantitativa, para as três faces, bem como o diâmetro médio de grão, para os dois aços [237]. Na tabela 4.2 são apresentados os resultados obtidos por ferritoscopia.

Tabela 4.1 - Fração volumétrica porcentual de ferrita determinada por estereologia quantitativa e tamanho de grão da ferrita e austenita para os aços dúplex e super dúplex.

\begin{tabular}{|c|c|c|c|c|c|c|}
\hline \multirow[b]{2}{*}{$\begin{array}{c}\text { Material como } \\
\text { recebido }\end{array}$} & \multicolumn{4}{|c|}{ Porcentagem de ferrita (estereologia) } & \multirow{2}{*}{$\begin{array}{l}\text { Diâmetro } \\
\text { médio de } \\
\text { grão } \\
\text { ferrita } \\
(\mu \mathrm{m})\end{array}$} & \multirow{2}{*}{$\begin{array}{c}\text { Diâmetro } \\
\text { médio de } \\
\text { grão } \\
\text { austenita } \\
(\mu \mathrm{m})\end{array}$} \\
\hline & Long. & Transv. & Sup. & Média total & & \\
\hline $\begin{array}{c}\text { Dúplex (UNS } \\
\text { S31803) }\end{array}$ & $46 \pm 4$ & $46 \pm 4$ & $44 \pm 4$ & $44 \pm 4$ & 25 & 25 \\
\hline $\begin{array}{l}\text { Super dúplex } \\
\text { (UNS S32520) }\end{array}$ & $45 \pm 3$ & $46 \pm 4$ & $46 \pm 4$ & $45 \pm 4$ & 35 & 34 \\
\hline
\end{tabular}


Tabela 4.2 - Fração volumétrica de ferrita determinada por ferritoscopia dos aços dúplex e super dúplex.

\begin{tabular}{ccccc}
\hline $\begin{array}{c}\text { Material como } \\
\text { recebido }\end{array}$ & \multicolumn{4}{c}{ Porcentagem de ferrita (Ferritoscopia) } \\
\cline { 2 - 5 } & Longitudinal & Transversal & Superficial & Média total \\
\hline $\begin{array}{c}\text { Dúplex (UNS } \\
\text { S31803) }\end{array}$ & $44 \pm 2$ & $44 \pm 2$ & $32 \pm 1$ & $40 \pm 6$ \\
$\begin{array}{c}\text { Super dúplex } \\
\text { (UNS S32520) }\end{array}$ & $41 \pm 3$ & $39 \pm 2$ & $30 \pm 2$ & $36 \pm 5$ \\
\hline
\end{tabular}

Comparando-se os valores de ferrita apresentados na tabela 4.1 e na tabela 4.2, observa-se que as médias totais obtidas com as duas técnicas concordaram razoavelmente. Por outro lado, as medidas obtidas por ferritoscopia apresentam menor desvio nas faces individualmente, mas apresentam maior desvio na média total. Esta discrepância pode ser explicada pelo efeito da orientação dos grãos de ferrita (textura cristalográfica) na permeabilidade magnética e, portanto, nas medidas realizadas por ferritoscopia. A forte textura cristalográfica presente em chapas laminadas de aços inoxidáveis dúplex dificulta a determinação da quantidade das duas fases por difração de raios X [247].

As determinações utilizando metalografia quantitativa (estereologia) também permitem afirmar que o diâmetro médio de grão do super dúplex é maior que o do dúplex. Essa variação pode ter sido causada por conta da área escolhida para a medida na superfície de laminação, pois é essa a direção responsável pelo aumento do tamanho de grão, inclusive para o dúplex. Na prática, na direção transversal e longitudinal, os dois aços apresentaram tamanhos semelhantes, tanto a austenita quanto a ferrita, na faixa de $10 \mu \mathrm{m}$.

A figura 4.1 e figura 4.2 mostram resultados de microscopia óptica do aço UNS S32520 e microscopia eletrônica de varredura do aço UNS S31803, respectivamente. 


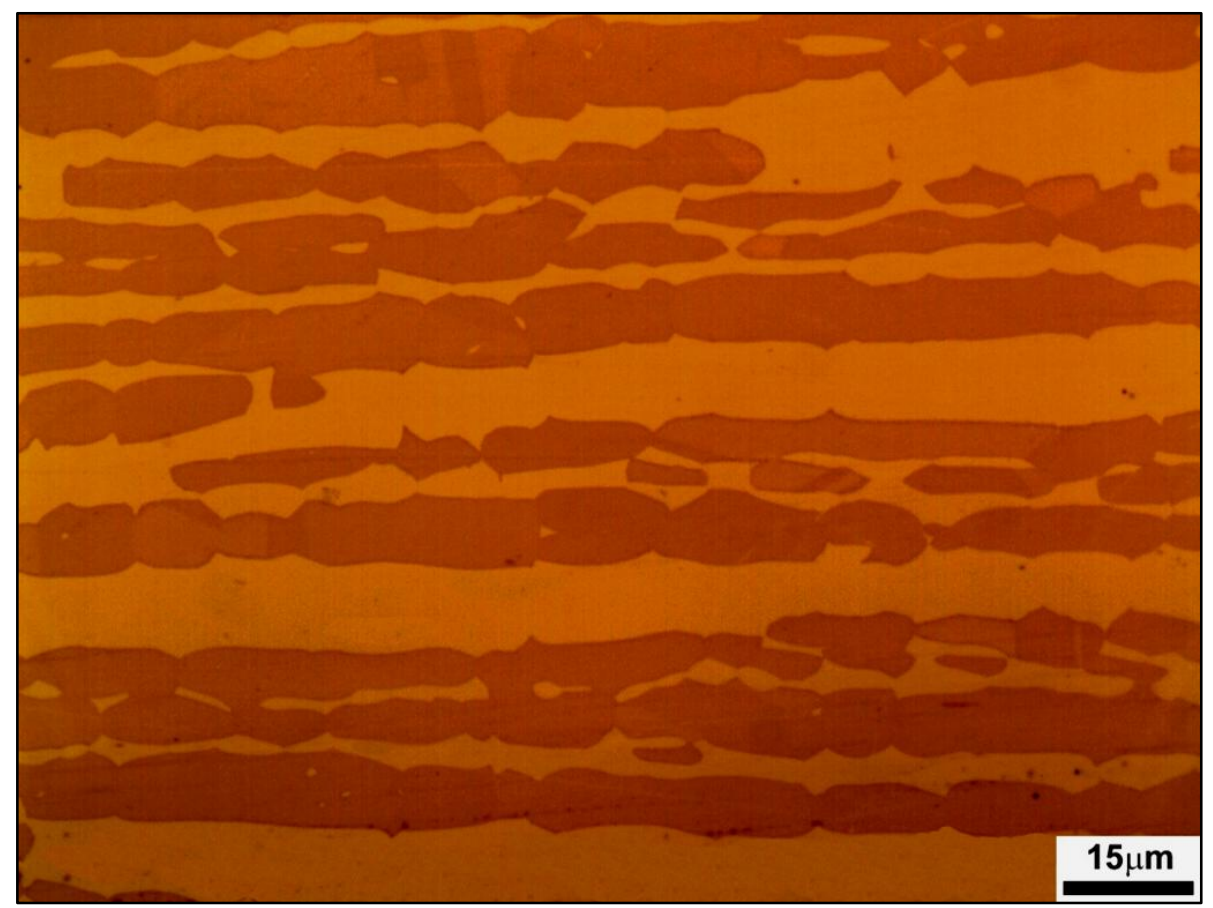

Figura 4.1 - Microscopia óptica da secção longitudinal do aço inoxidável super dúplex UNS S32520. Amostra atacada metalograficamente por chama de gás de cozinha (GLP) por aproximadamente 1 minuto.

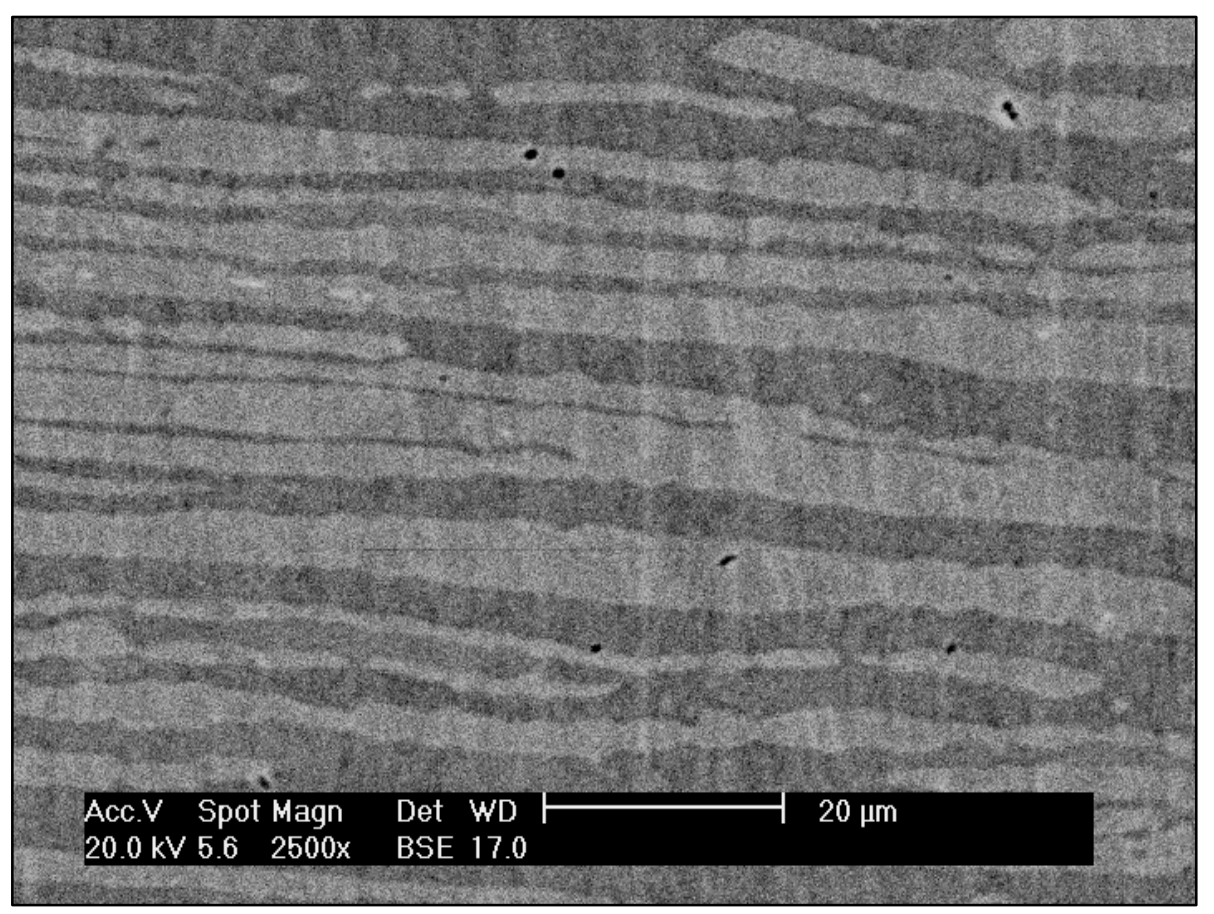

Figura 4.2 - Microscopia eletrônica de varredura com elétrons retroespalhados da secção longitudinal do aço inoxidável dúplex UNS S31803.

As duas fases de ambos os aços apresentaram grãos finos, de diâmetro médio de aproximadamente $30 \mu \mathrm{m}$ (entre 25 e $35 \mu \mathrm{m}$ ), alongados na direção de laminação, formando placas (lamelas em duas dimensões) alternadas de ferrita e 
austenita. A superfície de laminação é a responsável por um aumento nesse valor médio de tamanho de grão. Essa morfologia é típica de chapas laminadas de aços inoxidáveis dúplex e pode ser justificada [43] pelo fato da energia de interface (austenita/ferrita) ser menor que as energias dos contornos de grãos (ferrita/ferrita e austenita/austenita) e pode ser mais bem visualizada numa ilustração real obtida por microscopia óptica, em três dimensões, do aço inoxidável dúplex UNS S31803, conforme figura 4.3.

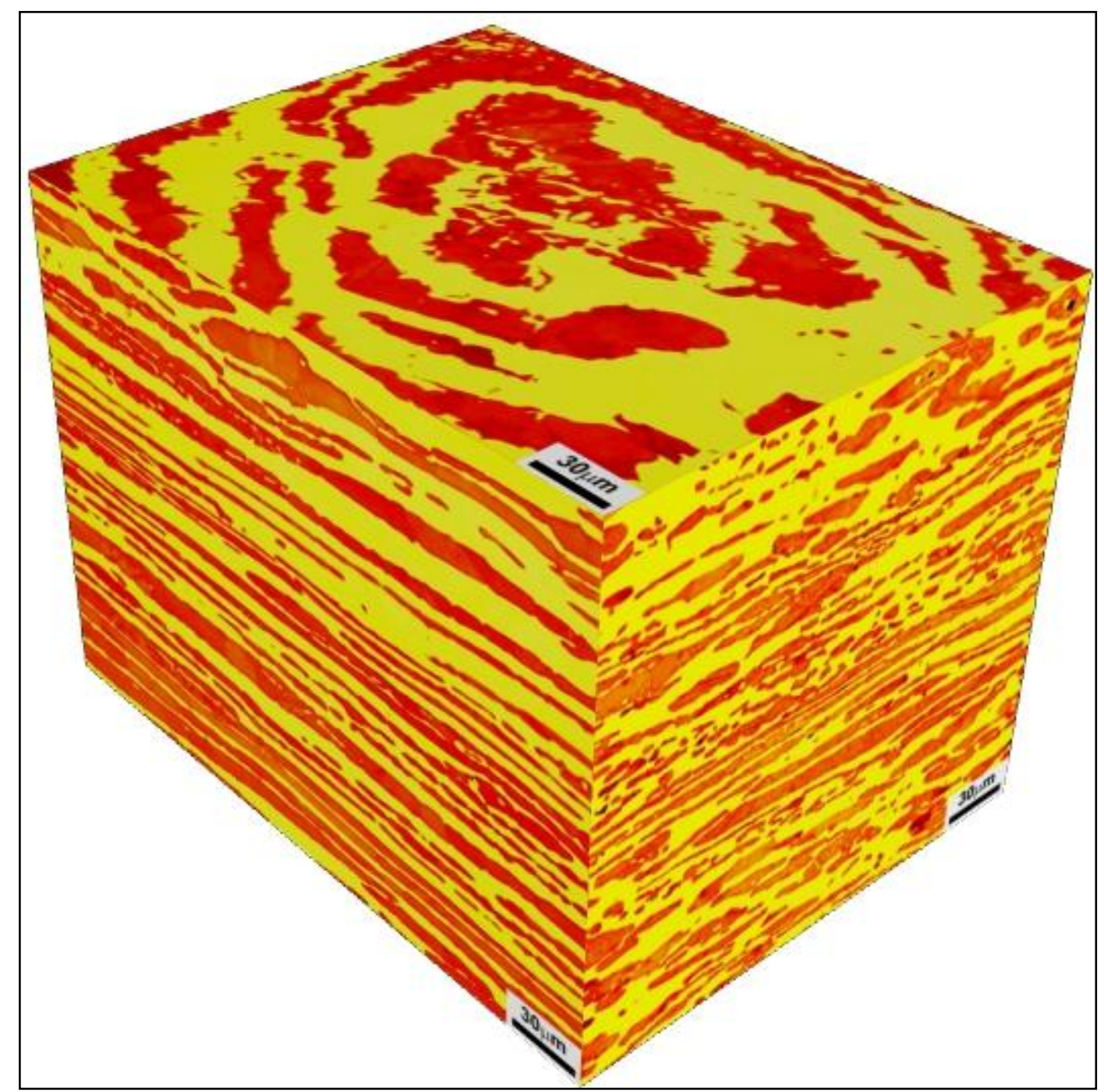

Figura 4.3 - Microscopia óptica em 3 dimensões do aço inoxidável dúplex UNS S31803. Amostra atacada metalograficamente por chama de gás de cozinha (GLP) por aproximadamente 1 minuto cada uma das faces.

Em seguida foi estudada a partição dos elementos metálicos nas duas fases dos dois aços inoxidáveis (dúplex e super dúplex), com auxílio de análise por dispersão de energia (vide tabela 4.3). Conforme esperado, a ferrita apresentou-se 
mais rica em cromo e molibdênio, enquanto a austenita é mais rica em níquel. Os coeficientes de partição encontrados neste trabalho foram comparados com os valores encontrados na literatura [62] e mostraram razoável concordância. A partir da composição química da austenita é possível avaliar as energias de defeito de empilhamento (EDE) da austenita dos dois aços e a suas propensões à formação de martensita induzida por deformação.

Tabela 4.3 - Porcentagem em massa dos elementos metálicos na ferrita e na austenita e a partição dos elementos nas duas fases $(\alpha / \gamma)$, determinadas por análise por dispersão de energia dos aços inoxidáveis dúplex e super dúplex.

\begin{tabular}{|c|c|c|c|c|c|c|c|}
\hline \multirow[t]{2}{*}{ Elemento } & \multicolumn{3}{|c|}{$\begin{array}{l}\text { Dúplex UNS S31803 } \\
\text { Porcentagem em massa }\end{array}$} & \multicolumn{3}{|c|}{$\begin{array}{c}\text { Super dúplex UNS } \\
\text { S32520 } \\
\text { Porcentagem em massa }\end{array}$} & \multirow[t]{2}{*}{$\begin{array}{l}\text { Partição a/y } \\
\text { extraída da } \\
\text { referência [62] }\end{array}$} \\
\hline & $\alpha$ & $\mathrm{V}$ & $\alpha / \gamma$ & $\alpha$ & $\mathrm{V}$ & $\alpha / \gamma$ & \\
\hline$\overline{\mathrm{Fe}}$ & 66,59 & 68,97 & $\overline{0,97}$ & 63,16 & 64,27 & 0,98 & 0,97 \\
\hline $\mathrm{Cr}$ & 23,68 & 21,7 & 1,09 & 27,3 & 24,44 & 1,12 & 1,17 \\
\hline $\mathrm{Ni}$ & 4,44 & 6,93 & 0,64 & 5,31 & 8,39 & 0,63 & 0,61 \\
\hline Mo & 3,6 & 2,44 & 1,48 & 4,22 & 2,91 & 1,45 & 1,59 \\
\hline
\end{tabular}

A energia de defeito de empilhamento da austenita do aço UNS S31803 foi calculada com auxílio da equação 3.4, proposta por Schramm e Reed [239] para aços inoxidáveis austeníticos.

Utilizando-se os coeficientes de partição da tabela 4.3 (adotando-se o coeficiente de partição 1 para o manganês) e os valores de composição química da tabela 3.1, obtêm-se pelo uso da equação 3.8 valores para a EDE de aproximadamente $40 \mathrm{~mJ} / \mathrm{m} 2$ e $55 \mathrm{~mJ} / \mathrm{m} 2$ para os aços dúplex e super dúplex, respectivamente. $\mathrm{O}$ uso direto da composição da austenita da tabela 4.3 (adotandose o coeficiente de partição 1 para o manganês) leva a valores de aproximadamente $30 \mathrm{~mJ} / \mathrm{m}^{2}$ e $45 \mathrm{~mJ} / \mathrm{m}^{2}$ para os aços dúplex e super dúplex, respectivamente. Portanto, é razoável supor que a austenita do aço inoxidável dúplex UNS S31803 do presente trabalho tenha uma EDE na faixa de 30 a $40 \mathrm{~mJ} / \mathrm{m}^{2}$ e a do super dúplex UNS S32520 tenha uma EDE mais alta, na faixa de 45 a $55 \mathrm{~mJ} / \mathrm{m}^{2}$. Para efeito de comparação, a EDE dos aços AISI 304L e 316L situam-se nas faixas de 9,2 - 41,8 $\mathrm{mJ} / \mathrm{m}^{2}$ e de 34,6 - $80,7 \mathrm{~mJ} / \mathrm{m}^{2}$, respectivamente [51]. Como nos dois aços inoxidáveis austeníticos mencionados, principalmente no AISI $304 \mathrm{~L}$ ocorre 
significativa formação de martensita induzida por deformação ( $\alpha$ ') [52], é razoável esperar formação de $\alpha^{\prime}$ nos dois aços inoxidáveis dúplex do presente trabalho, principalmente no UNS S31803 que tem menor EDE. Além disto, como na comparação entre os aços AISI 304L e 316L [50 - 52], é razoável esperar quantidades mais elevadas de martensita induzida por deformação no aço dúplex do que no aço super dúplex.

\subsection{Curvas de dureza versus redução para a laminação dos aços inoxidáveis dúplex UNS S31803 e super dúplex UNS S32520}

Os dados apresentados representam as médias globais de 45 medidas (15 medidas em cada face) para cada condição de redução, com suas respectivas barras de erros experimental. Os resultados dos aços UNS S31803 (dúplex) e UNS S32520 (super dúplex) são apresentados na figura 4.4, conforme legenda de cores.

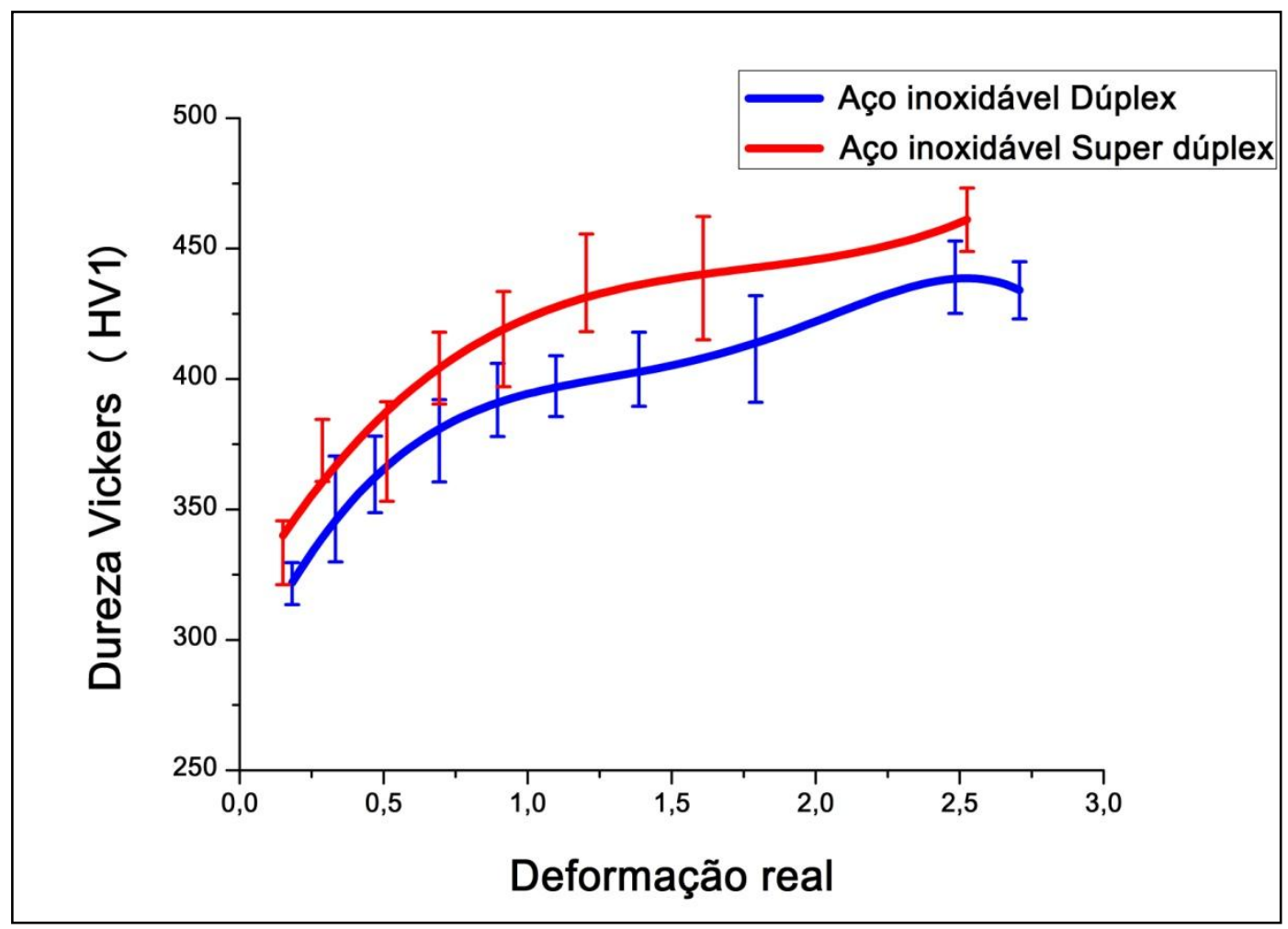

Figura 4.4 - Curva de dureza Vickers (HV1) versus deformação real para os aços inoxidáveis dúplex e super dúplex.

Nota-se pelos valores de dureza que o comportamento dos dois aços é similar perante deformação por laminação a frio. 
Pequenas oscilações que ocorrem podem estar relacionadas com heterogeneidades de deformação, mesmo que o fator delta tenha sido mantido menor que 1. Na prática, deformações nunca são homogêneas, mesmo tomando-se o cuidado de usar fator delta menor que 1.

É possível observar que a laminação provoca o endurecimento gradativo dos dois materiais, por mecanismos de multiplicação e interação entre defeitos cristalinos, especialmente entre discordâncias. Todavia, apenas com auxílio de medidas de dureza é impossível determinar se houve ou não transformação martensítica induzida por deformação, que é o foco principal desta pesquisa.

\subsection{Distribuição granulométrica das partículas obtidas por limagem}

Os ensaios de distribuição do tamanho de partícula dos cavacos produzidos por limagem, apresentaram curva de distribuição Gaussiana para os dois aços, como visto na figura 4.5, para o aço dúplex e figura 4.6 para o super dúplex.

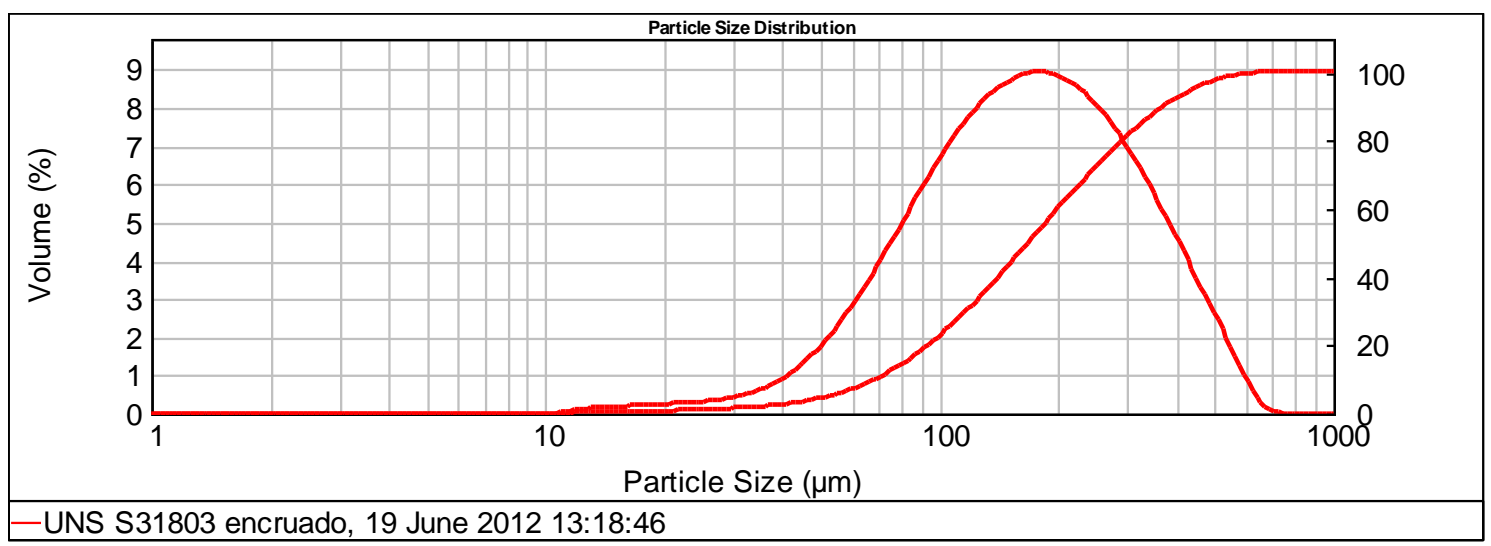

Figura 4.5 - Distribuição de tamanho de partículas produzidas por limagem, do aço inoxidável dúplex UNS S31803.

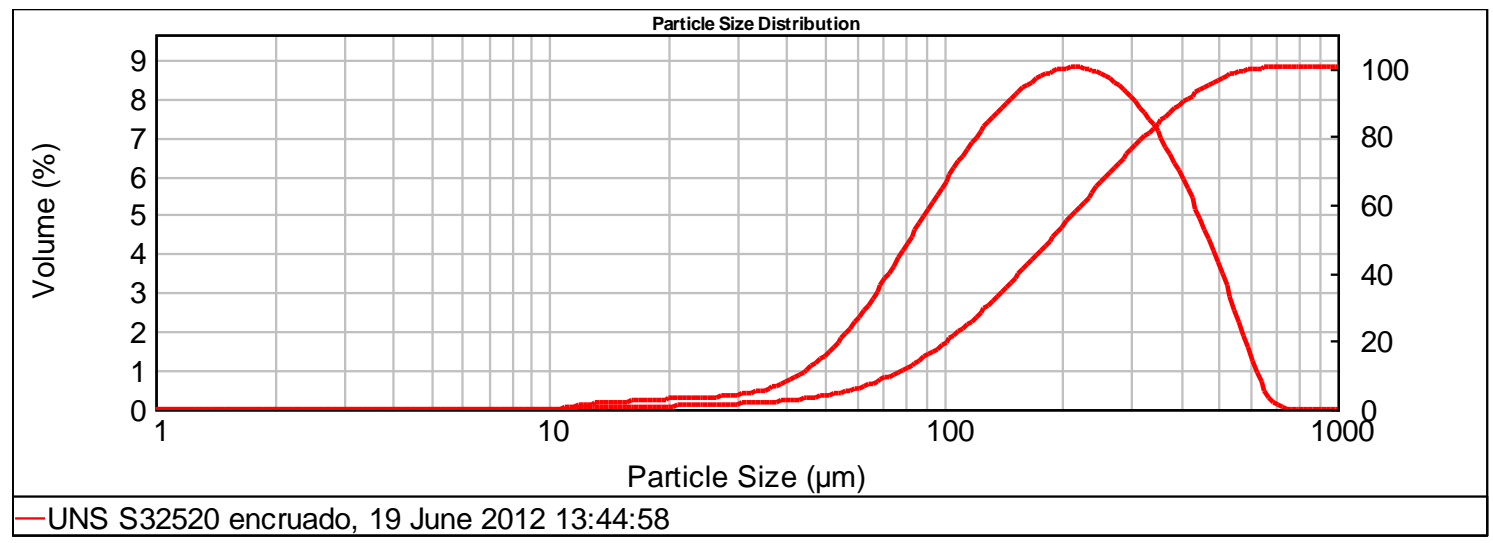

Figura 4.6 - Distribuição de tamanho de partículas produzidas por limagem, do aço inoxidável super dúplex UNS S32520. 
A leitura dos dados permite extrair alguns resultados expressos na tabela 4.4 .

Tabela 4.4 - Distribuição do tamanho de partículas dos aços inoxidáveis dúplex UNS S31803 e super dúplex UNS S 32520

DÚPLEX SUPER DÚPLEX

\begin{tabular}{lll}
\hline Diâmetro médio $(\boldsymbol{\mu m})$ & 198 & 219 \\
Diâmetro $50 \%(\mu \mathrm{m})$ & 169 & 190 \\
Diâmetro $90 \%(\mu \mathrm{m})$ & 374 & 410 \\
\hline
\end{tabular}

Isto significa que para o aço dúplex as partículas têm um tamanho médio de $198 \mu \mathrm{m}$ enquanto o super dúplex $219 \mu \mathrm{m}$. Ainda, 50 e $90 \%$ das partículas do dúplex estão abaixo de 169 e $374 \mu \mathrm{m}$, respectivamente, enquanto que 50 e $90 \%$ das partículas do super dúplex estão abaixo de 190 e $410 \mu \mathrm{m}$, respectivamente.

\subsection{Resultados de raios $X$ e refinamento de Rietveld dos cavacos produzidos por limagem dos aços inoxidáveis dúplex UNS S31803 e super dúplex UNS S32520}

Também foram realizadas experiências com cavaco produzido por limagem. A cominuição por limagem é conhecida por causar grande quantidade de deformação plástica e de defeitos cristalinos [56, 248]. De fato, é possível observar uma partícula de cavaco muito deformada e de maneira heterogênea com o auxílio da figura 4.7, obtida por microscopia eletrônica de varredura de alta resolução (FEG - Field emission gun). Este exemplo é de uma amostra de cavaco limado de aço inoxidável super dúplex UNS S31803, que foi tratado por 1 hora a $750 \stackrel{\circ}{\circ}$. A imagem foi obtida com elétrons retroespalhados e as regiões escuras são de austenita e as regiões claras de ferrita. 


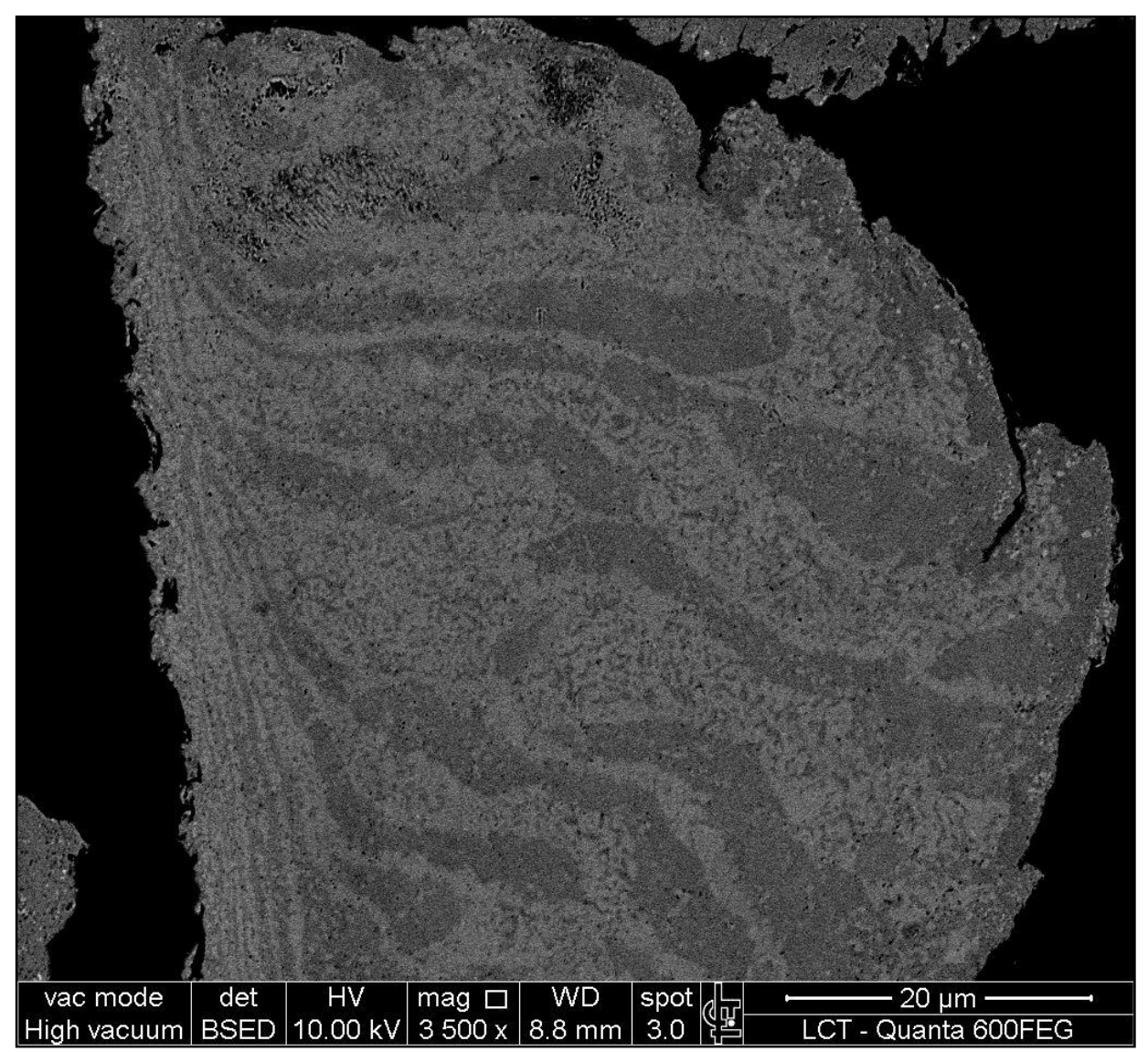

Figura 4.7 - Partícula de cavaco limado do aço inoxidável super dúplex UNS S31803, tratado a 750 oC por 1 hora. É possível observar as bordas bastante deformadas devido ao processo de limagem. Regiões claras de ferrita e escuras de austenita.

De acordo com trabalhos anteriores realizados em chapas [49, 50, 62], o recozimento a $600^{\circ} \mathrm{C}$ por 1 hora é suficiente para causar reversão da martensita alfa linha para austenita, mas não é suficiente para causar recristalização da austenita e/ou da ferrita. Embora as medidas magnéticas no cavaco com auxílio do ferritoscópio sejam difíceis e imprecisas, foi possível detectar a redução do magnetismo nas amostras recozidas a $600{ }^{\circ} \mathrm{C}$ por 1 hora, em comparação com amostras do cavaco encruado.

Um panorama completo dos efeitos de todos os tratamentos térmicos, em relação ao material encruado, pode ser visualizado por meio de figuras de difração de raios $\mathrm{X}$. Na figura 4.8 são apresentadas as figuras de difração superpostas do cavacos de aço inoxidável dúplex UNS S31803 após limagem (encruado) e tratados termicamente como apresentado anteriormente na tabela 3.4. Mudanças nos perfis dos picos de difração do aço UNS S31803 poderão ser melhor observadas em uma análise mais detalhada, conforme ilustra a figura 4.9. 


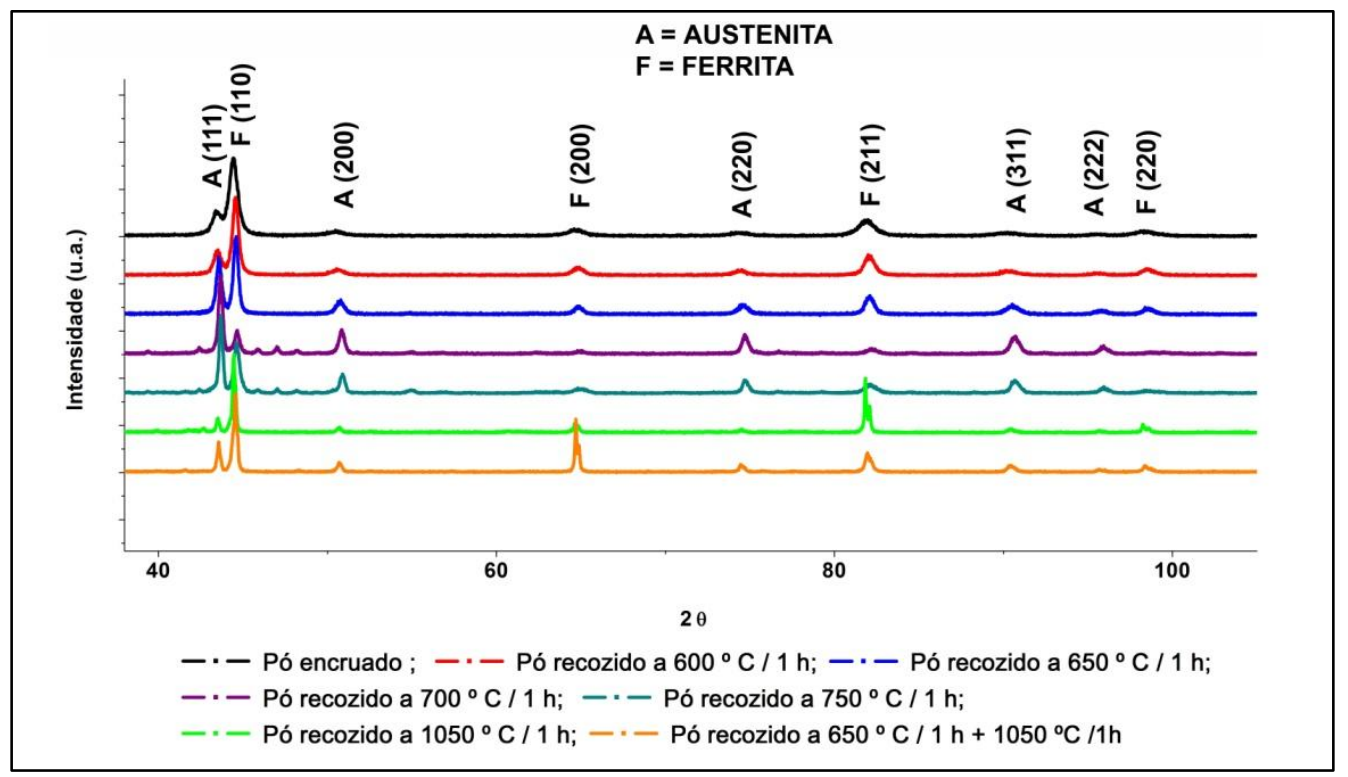

Figura 4.8 - Figura de difração de raios $X$ do cavaco produzido por limagem do aço inoxidável dúplex UNS S31803 encruado (preto) e tratados termicamente (conforme legenda). Radiação CuKa.

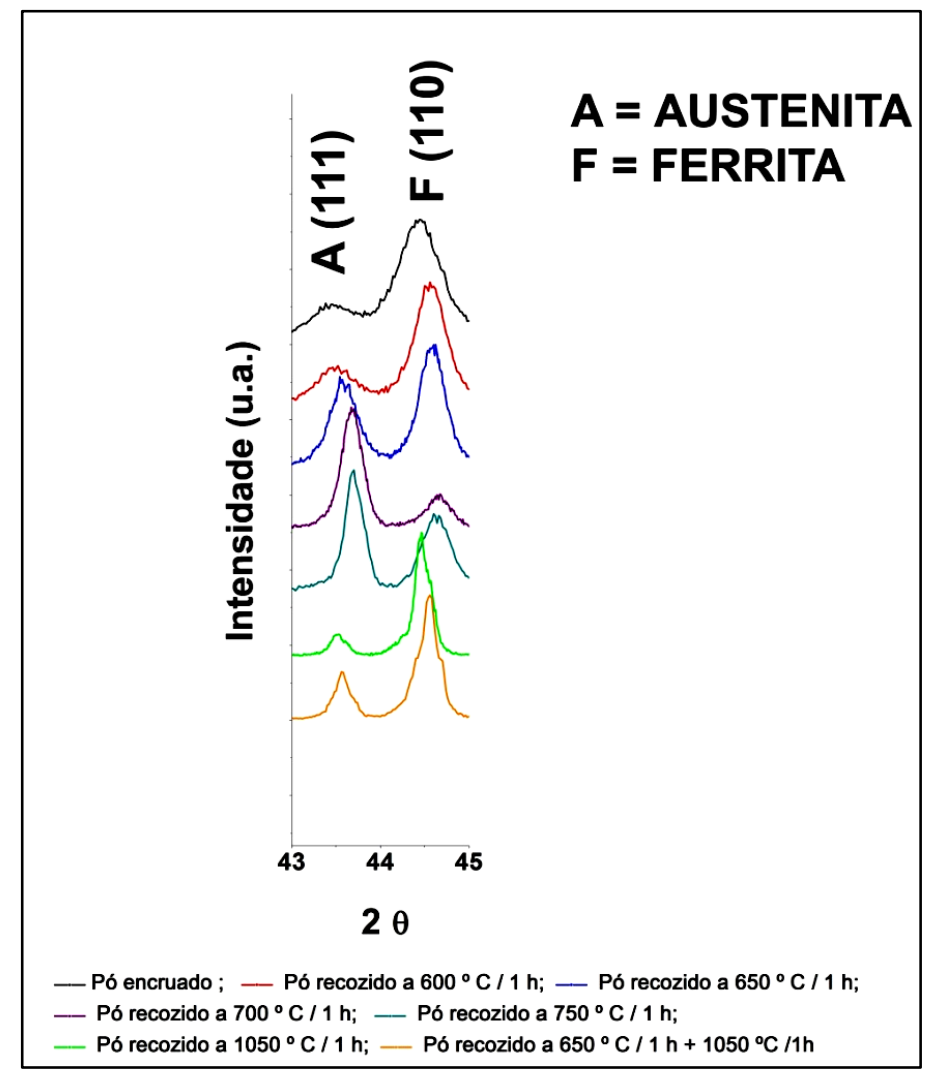

Figura 4.9 - Detalhe da figura de difração de raios x (Figura 4.8), mostrando apenas os picos (111) da austenita e (110) da ferrita do aço UNS S31803. Radiação CuKa.

A figura 4.8 revela que os recozimentos realizados causaram variações na difração de raios $X$, isto é, alteraram-se os alargamentos e as intensidades dos picos. Inclusive, no caso de $700^{\circ} \mathrm{C}$, alterou-se o número de picos pela precipitação 
da fase sigma. Ao investigar os efeitos dos tratamentos na austenita e ferrita, é observardo com mais detalhes na figura 4.9 que ocorre uma diminuição na largura dos picos e também um aumento da altura dos mesmos em relação à amostra encruada, para as duas fases. Este comportamento está associado com a diminuição das microtensões causadas pelo recozimento, devido aos processos de recuperação que ocorrem nas duas fases, especialmente na ferrita, onde a difusão é mais rápida e a mobilidade das discordâncias maior. Além disto, a reversão da martensita alfa linha, cujos picos se superpõem com os da ferrita, em austenita, deve contribuir para a diminuição da intensidade (área) dos picos de ferrita e aumento da intensidade (área) dos picos de austenita [240].

$\mathrm{Na}$ figura 4.10 são apresentadas as figuras de difração superpostas dos cavacos de aço inoxidável super dúplex UNS S32520 após limagem (encruado) e tratados termicamente nas condições indicadas anteriormente na tabela $3.4 \mathrm{e}$ também expressas nas legendas de cores na própria figura. Mudanças nos perfis dos picos de difração do aço UNS S32520 poderão ser melhor observadas em uma análise mais detalhada, conforme ilustra a figura 4.11:

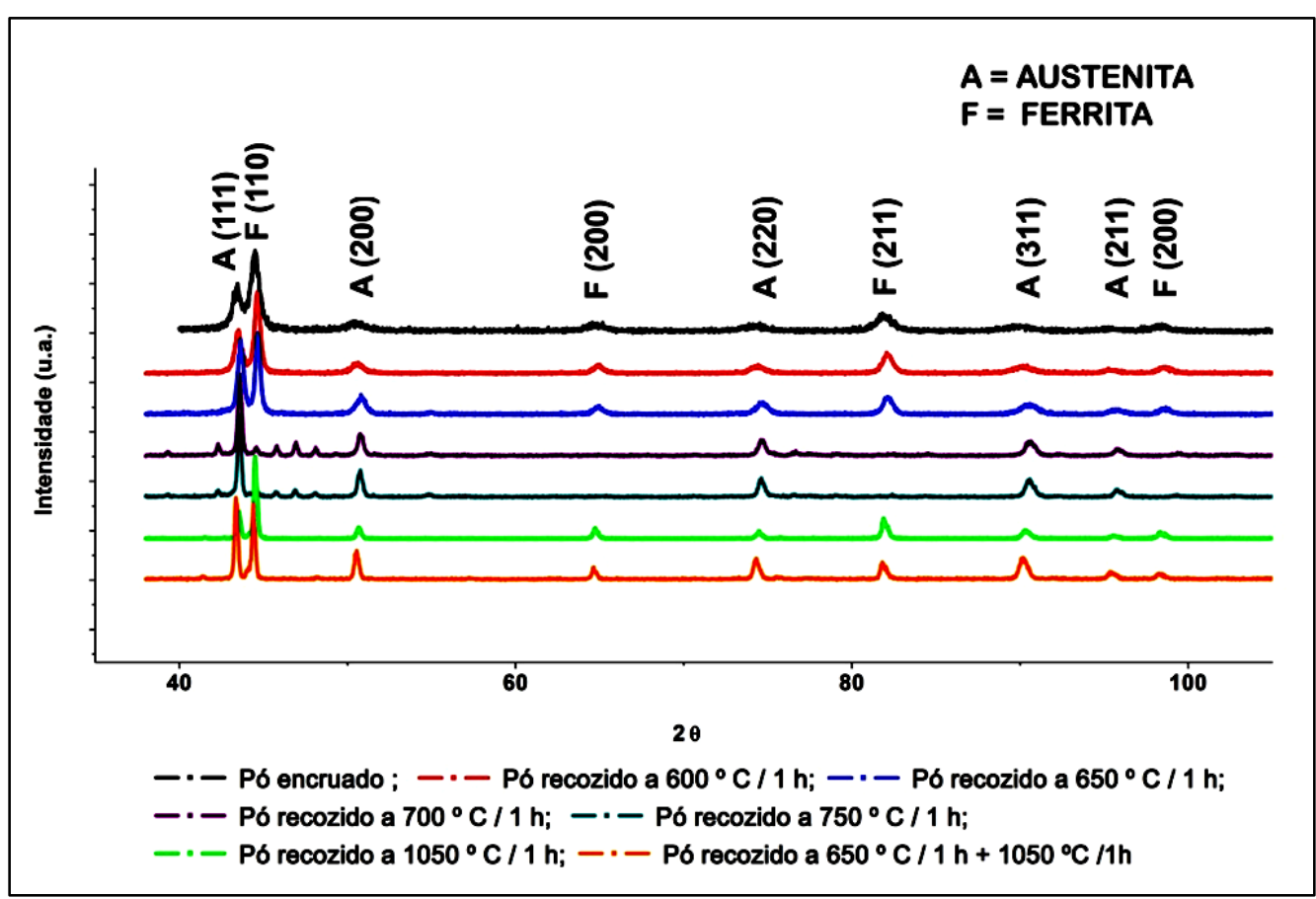

Figura 4.10 - Figura de difração de raios $X$ do cavaco produzido por limagem do aço inoxidável super dúplex UNS S32520 encruado (preto) e tratados termicamente (conforme legenda). Radiação CuKa. 


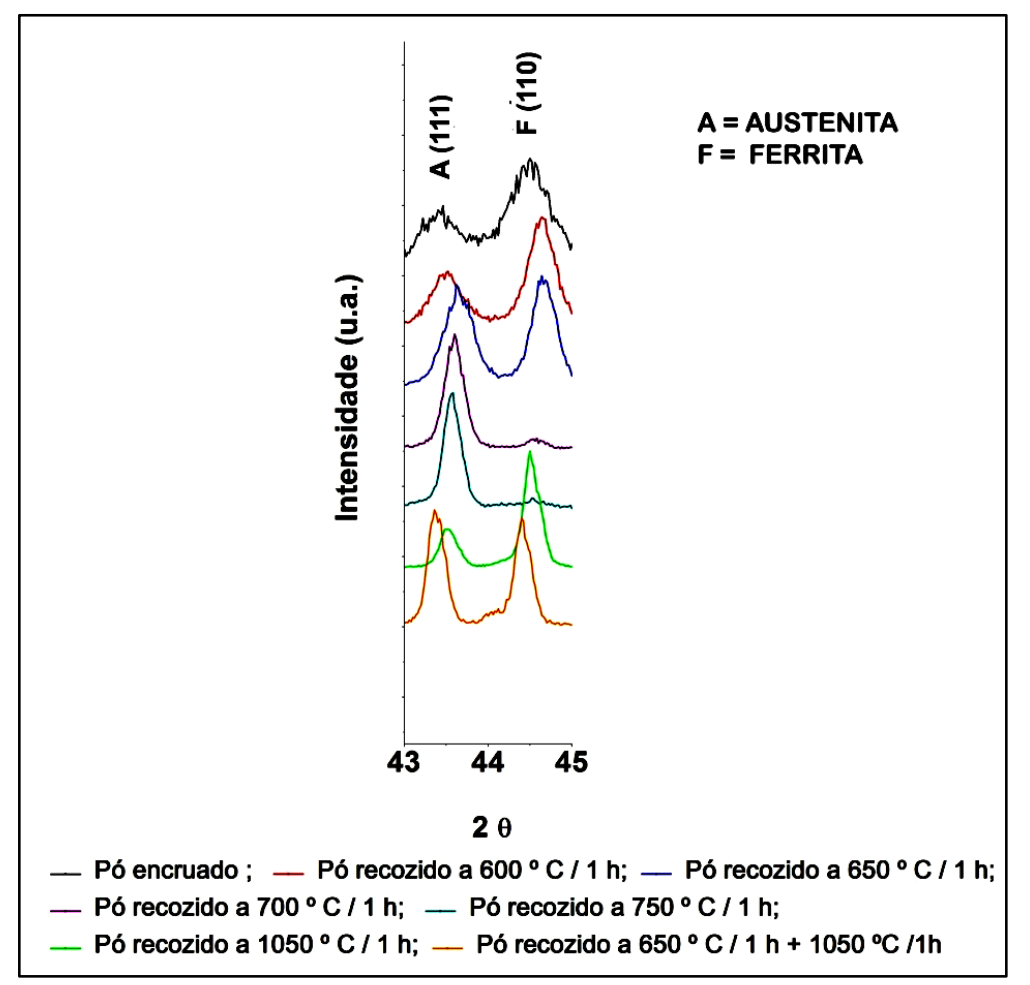

Figura 4.11 - Detalhes da figura de difração (Figura 4.10), mostrando apenas os picos (111) da austenita e (110) da ferrita do aço UNS S31520. Radiação CuKa.

A figura 4.10 revela que os recozimentos realizados causaram variações na figura de difração do aço UNS 32520, isto é, alteraram-se os alargamentos e as intensidades dos picos. Inclusive, no caso de 700 e $750^{\circ} \mathrm{C}$, alteraram-se o número de picos pela precipitação da fase sigma, de forma muito similar ao que ocorreu com o aço UNS S31803.

Pode-se observar na figura 4.11 que após o tratamento térmico, ocorre uma diminuição na largura dos picos e também um aumento da altura dos mesmos, nas duas fases. Da mesma maneira como ocorreu com o aço inoxidável dúplex UNS S31803, este comportamento está associado com a diminuição das microtensões causada pelo recozimento, devido aos processos de recuperação e recristalização que ocorrem nas duas fases, especialmente na ferrita, onde a difusão é mais rápida. Além disto, a reversão da martensita alfa linha, cujos picos se superpõem com os da ferrita, em austenita, deve contribuir para a diminuição da intensidade (área) dos picos de ferrita e aumento da intensidade (área) dos picos de austenita [240].

Adicionalmente, observa-se no pico (111) da austenita a diferença entre o comportamento do cavaco recozido diretamente a $1050 \stackrel{\circ}{\mathrm{C}}$ por 1 hora (linha verde no gráfico) e o que foi previamente recozido a $650 \stackrel{\circ}{\mathrm{C}}$ por 1 hora e posteriormente $1050 \stackrel{\circ}{C}$ por 1 hora (linha laranja no gráfico). 
No caso do cavaco tratado a $650{ }^{\circ} \mathrm{C}$ por 1 hora (temperatura capaz de reversão da martensita induzida por deformação para austenita) antecedendo o tratamento de $1050 \stackrel{\circ}{\circ}$ por 1 hora, a fração volumétrica de austenita foi maior que quando tratado diretamente a $1050 \stackrel{\circ}{\circ} \mathrm{C}$ por 1 hora, de acordo com a intensidade dos picos quando observa-se o plano (111) da austenita na figura 4.11.

Algumas causas para a diferença entre o tratamento direto a $1050 \stackrel{\circ}{\circ} \mathrm{C}$ e $\mathrm{O}$ tratamento a $1050 \stackrel{\circ}{\circ}$ passando por um tratamento intermediário de $650{ }^{\circ} \mathrm{C}$, todos pelo tempo de 1 hora, serão discutidas na sequência quando forem apresentadas as análises quantitativas de fases, que é uma das informações adicionais que foram obtidas, com o auxílio do refinamento matemático nos perfis de difração pelo método de Rietveld [244, 245].

A figura 4.12 se refere ao aço UNS S31803. Ela mostra o resultado das quantidades de fase ferromagnética (ferrita ou ferrita + martensita induzida por deformação), de fase gama (austenita) e de fase sigma nas amostras encruada e tratadas termicamentes conforme citado anteriormente na tabela 3.4.

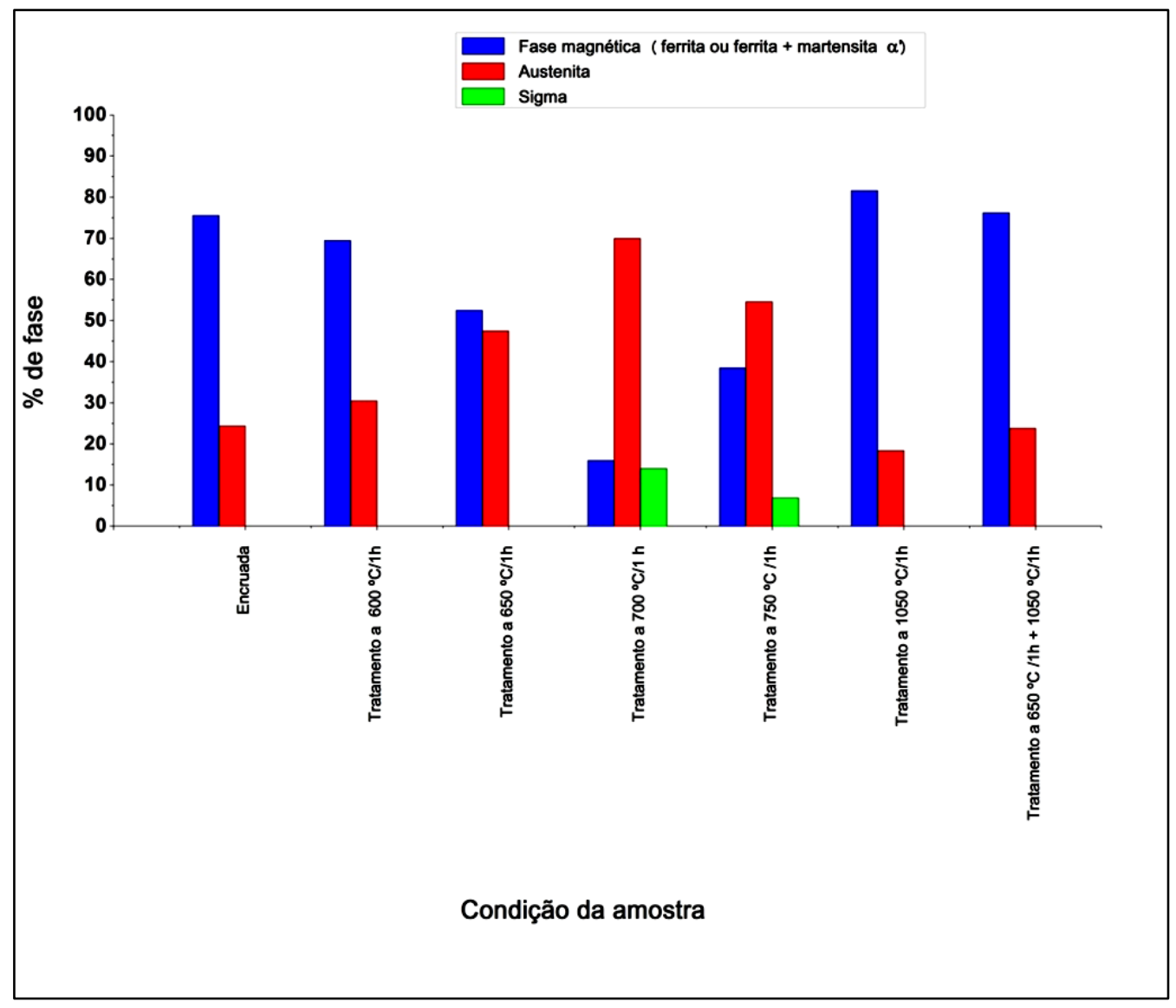

Figura 4.12 - Quantidade de fases determinada por difração de raios $X$ seguida de refinamento de Rietveld para o aço UNS S31803. 
Uma primeira informação extraída da figura 4.12 é que no estado encruado o cavaco apresentava em torno de $76 \%$ de fase magnética e $24 \%$ de austenita. Cerca de $6 \%$ e $23 \%$ de fase ferromagnética foi revertida para austenita (31\% e 47 $\%)$ com o tratamentos térmicos de $600{ }^{\circ} \mathrm{C}$ e $650{ }^{\circ} \mathrm{C}$, respectivamente. Além disto, comparando-se os resultados da tabela 4.1 e tabela 4.2 (obtidos na chapa) com os resultados da figura 4.12 (obtidos com cavaco) observam-se teores bem mais elevados a $600{ }^{\circ} \mathrm{C}$ e levemente mais elevados a $650 \stackrel{\circ}{ } \mathrm{C}$ de fase ferromagnética nas amostras na forma de cavaco. No caso da amostra encruada, a explicação é a presença de martensita alfa linha, enquanto na amostras tratadas termicamentes, os teores mais altos (em comparação com os resultados da tabela 4.1 e tabela 4.2) de fase ferromagnética sugerem uma reversão incompleta da martensita em austenita.

Sabe-se que inicialmente no estado encruado o cavaco tinha fração volumétrica de fase magnética (ferrita + martensita alfa linha) próxima de $76 \%$. As análises realizadas nas amostra tratada a $700 \stackrel{\circ}{\circ}$, mostram $16 \%$ de fase magnética permaneceu magnética. Parte dela foi revertida em austenita e parte em fase sigma. $\mathrm{O}$ aparecimento da fase sigma e aumento da fração de austenita se deve a dois fatores que são a reversão da martensita induzida por deformação na austenita [77, 78] e decomposição eutetóide da ferrita. Essa reação eutetóide (ferrita $\rightarrow$ austenita secundária + fase sigma) é esperada nessa faixa de temperatura [48, 229, 230]. A mesma decomposição acontece a $750{ }^{\circ} \mathrm{C}$ e é um pouco mais pronunciada que a 700 $\stackrel{\circ}{\circ}$.

Os tratamentos de $1050 \stackrel{\circ}{\circ}$, diretamente e passando por um estágio intermediário de $650 \stackrel{\circ}{\circ}$ por 1 hora para reversão de martensita, no dúplex, não diferem significativamente e resultam em 82 e $76 \%$ de fase magnética, respectivamente.

Também foi realizada a análise quantitativa de fases a partir de difração de raios X e refinamento de Rietveld para o aço super dúplex UNS S32520, naquelas condições já citadas na tabela 3.4. Essa análise é mostrada na figura 4.13. 


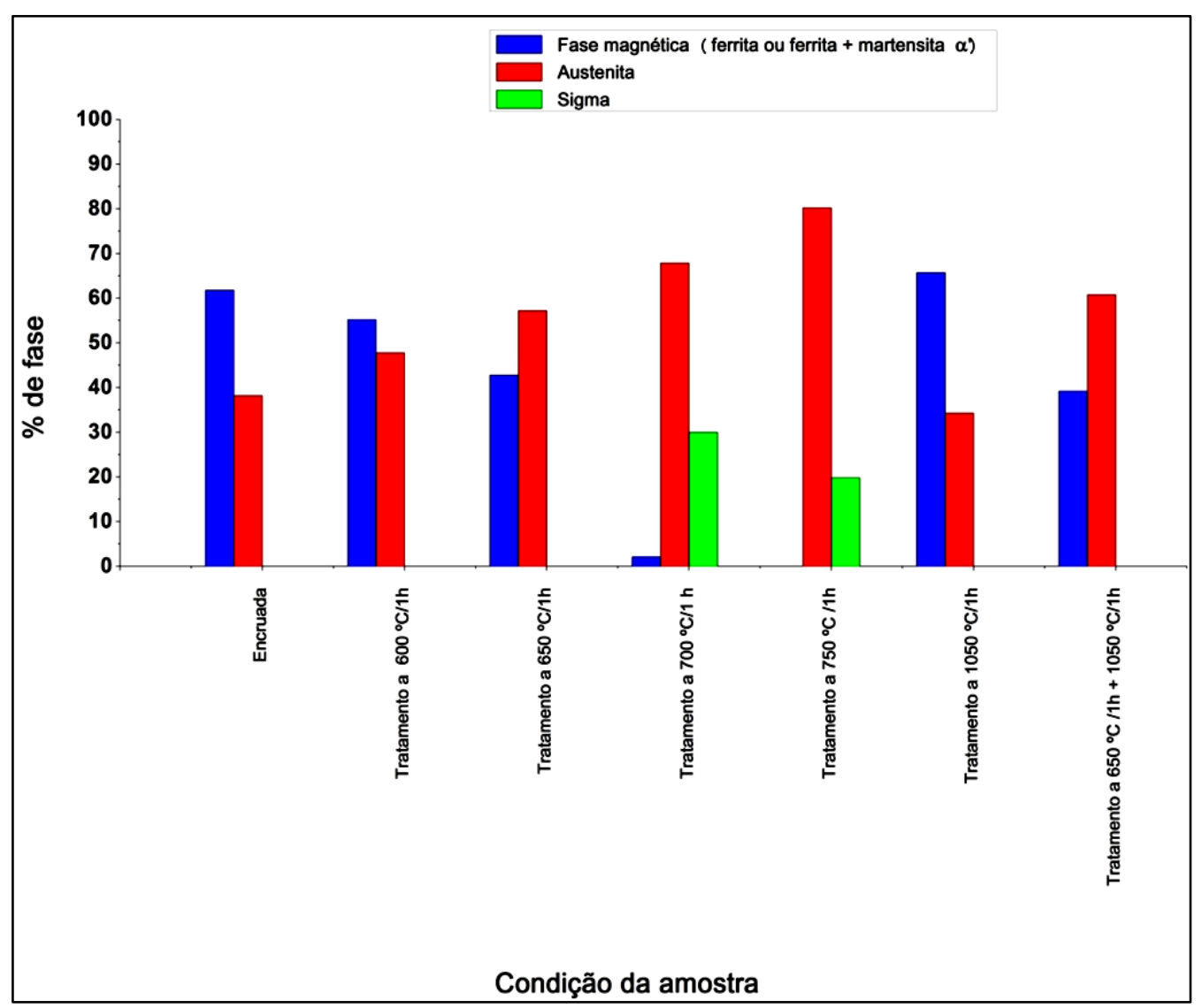

Figura 4.13 - Quantidade de fases determinada por difração de raios $X$ seguida de refinamento de Rietveld para o aço UNS S32520.

A quantidade de fase magnética encontrada para o cavaco de aço inoxidável super dúplex UNS S32520 encruado por limagem foi em torno de 62 \%, $13 \%$ menor que no aço inoxidável dúplex UNS S31803. Um fator pode ter sido determinante para isso:

- Maior teor do intersticial nitrogênio (altamente estabilizador do campo austenítico), o que torna a austenita do super dúplex menos metaestável que a austenita do dúplex.

Houve reversão da fase magnética nos tratamentos de 600 e $650 \stackrel{\circ}{\circ}$ por 1 hora, assim como havia ocorrido com o dúplex. As proporções de reversão foram bem parecidas (7 \% e $19 \%$, respectivamente), totalizando em $55 \%$ de fase magnética pra $600^{\circ} \mathrm{C}$ e $43 \%$ para $650^{\circ} \mathrm{C}$.

Também houve precipitação de fase sigma para os tratamentos de $700 \mathrm{e}$ 750 ํ. Comparando-se estes tratamentos, as proporções de fase sigma são maiores no super dúplex, concordando com a teoria de que os aços inoxidáveis super dúplex são mais suceptíveis à essa precipitação, pois sua ferrita é mais 
instável devido sua composição química, aumentando a cinética de precipitação [87, 232,233 ] e também a fração volumétrica de tal fase.

O tratamento de $1050 \stackrel{\circ}{\circ}$ por 1 hora também foi realizado para duas condições diferentes. Uma delas, diretamente do estado encruado e a outra, passando por uma temperatura intermediária de reversão da martensita $(650 \stackrel{\circ}{\mathrm{C}}$ por 1 hora). A fração volumétrica desses dois casos foi significativamente diferente. No caso do recozimento direto, têm-se $66 \%$ de ferrita e $34 \%$ de austenita, enquanto que, no caso do cavaco em que se reverteu a martensita, têm-se $39 \%$ de ferrita e $61 \%$ de austenita.

O processo de limagem causa uma altíssima deformação plástica no material [56, 248], induzindo a formação de martensita (CCC) [56]. Durante o processo de recozimento desse cavaco diretamente a $1050{ }^{\circ} \mathrm{C}$, a energia térmica fornecida favorece os processos de recristalização tanto [79 - 81] da ferrita quanto 0 da austenita. A fase martensítica pode ter se recristalizado como ferrita, ao invés de reverter para austenita. Alguns fatores podem supostamente ter contribuído para isso:

- A estrutura martensítica tem os mesmos parâmetros de rede da ferrita;

- Esses aços possuem uma austenita com elevados teores de elementos ferritizantes como cromo e molibdênio (vide tabela 3.1 e tabela 3.2), consequentemente, a martensita induzida por deformação, também será rica em tais componentes químicos;

- Os super dúplex têm mais nitrogênio (austenitizante) que os dúplex;

- A $1050 \stackrel{\circ}{\circ}$ os coeficientes de difusão dos elementos químicos são muito altos. A martensita induzida por deformação, que gera muita microdeformação residual (como será discutido nos próximos parágrafos), é muito instável e a ferrita estável. O aquecimento rápido até essa temperatura elevada, pode ter favorecido energeticamente a diminuição da deformação da estrutura por difusão, estabilizando a ferrita a partir dessa martensita, ao invés de revertê-la para austenita;

- A fração de austenita restante, pode estar bastante rica nos elementos gamagênicos presentes (nitrogênio, manganês e níquel) e empobrecida de cromo e molibidênio; 
- No super dúplex, quando há tratamento intermediário de $650{ }^{\circ} \mathrm{C}$ por 1 hora, o alto teor de nitrogênio comparado ao dúplex, ajuda a estabilizar a austenita novamente, diferenciando os dois aços no segundo estágio a $1050 \stackrel{\circ}{\circ}$.

Porém, para que todas essas suposições acima sejam aceitas, devem-se proceder investigações mais rigorosas e detalhadas nesse cavaco. Por exemplo, embora possa ser muito difícil e trabalhoso, um estudo de microscopia eletrônica de transmissão no cavaco poderia ajudar a reforçar ou descartar estas suposições.

Ainda extraindo informações dos detalhes das figuras de difração (figura 4.9 e figura 4.11), nota-se que há um certo alargamento nos picos da amostra encruada e que esse alargamento vai diminuindo a medida em que a amostra é tratada termicamente.

Tanto partículas muito finas como microdeformações residuais [240 - 243] podem causar alargamento dos picos de difração.

Por exemplo, considerando uma determinada estrutura livre de defeitos, um determinado pico de difração é observado. Essa estrutura quando deformada, terá campos de tração onde o pico será deslocado para valores de $2 \theta$ maiores, bem como, terá campos de compressão que deslocará os picos de difração para valores de $2 \theta$ menores. Esses dois efeitos farão com que a leitura dos picos do material deformado tenham menor intensidade e que haja alargamento em relação à uma estrutura não deformada [240 - 243]. As já mostradas figura 3.3 e figura 3.4 auxiliam no entendimento dos efeitos das microdeformações no alargamento dos picos de difração.

No presente trabalho, após o refinamento pelo método Rietveld, foram obtidos os valores de alargamento dos picos. A figura 4.14 apresenta o alargamento $(\Delta 2 \theta \cos \theta)$ dos picos em função do sen $\theta$ da ferrita do aço inoxidável dúplex UNS S31803 para as condições da amostra encruada e recozidas tabela 3.4. Já a figura 4.15 mostra a mesma análise de alargamento da ferrita do aço inoxidável super dúplex UNS S32520 nas condições encruada e recozidas, descritas na mesma tabela.

As curvas são crescentes e aproximadamente lineares. 


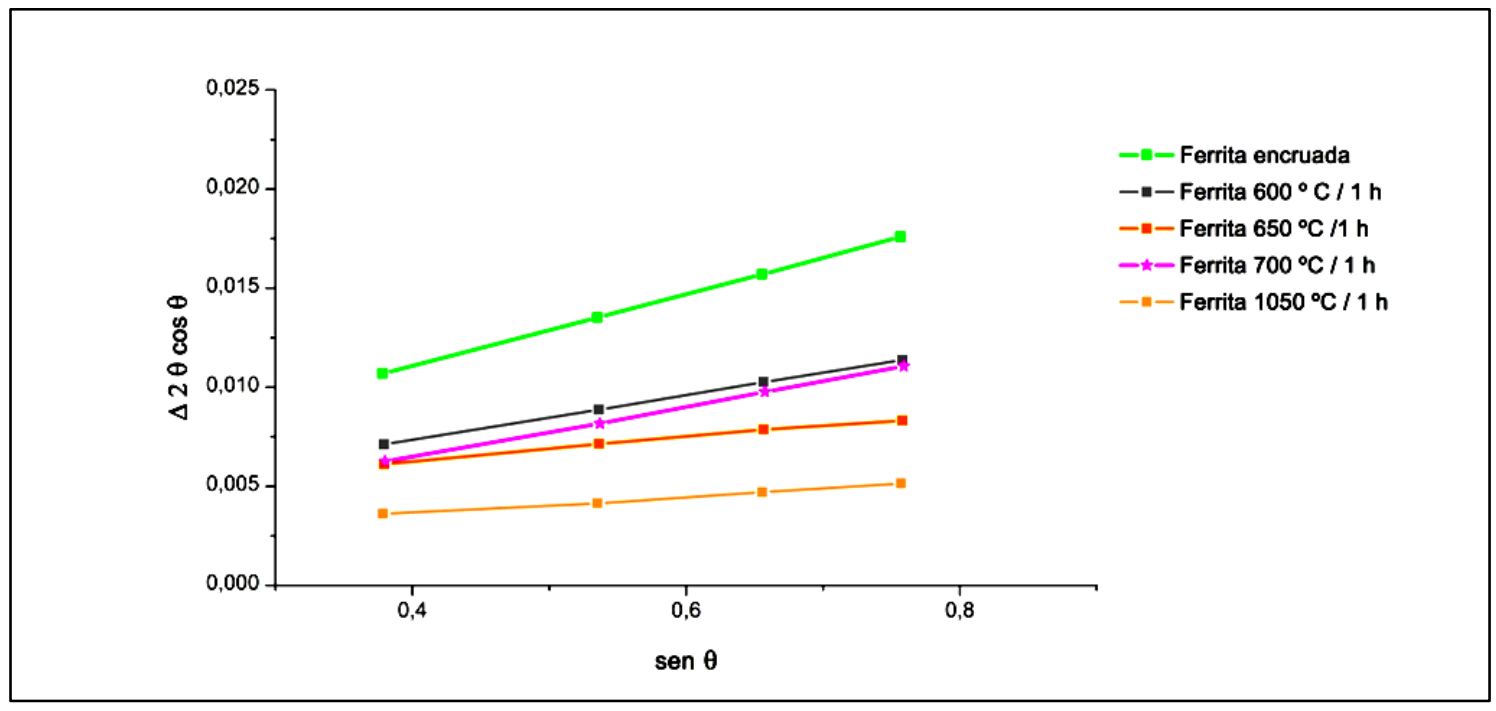

Figura 4.14 - Valores de alargamento dos picos de difração versus sen $\theta$ da ferrita do aço inoxidável dúplex UNS S31803.

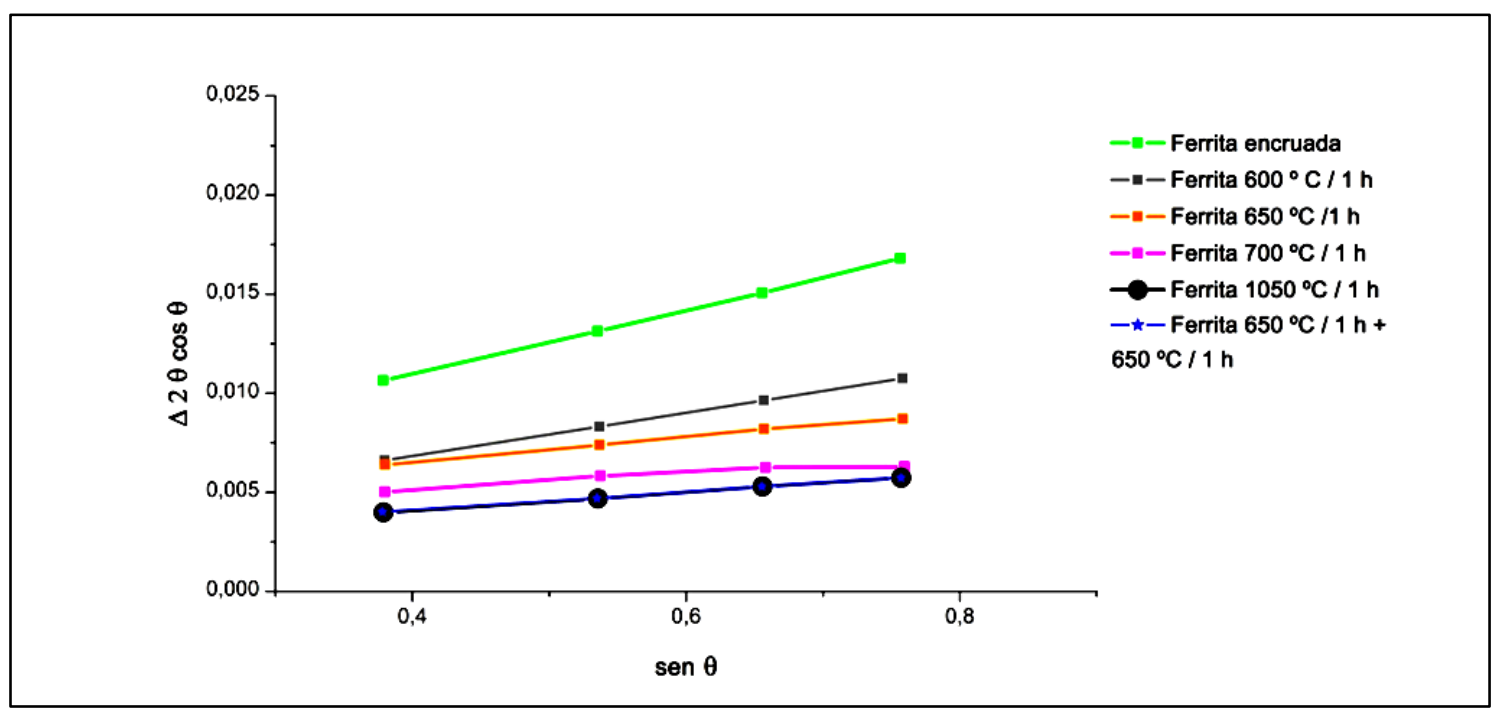

Figura 4.15 - Valores de alargamento dos picos de difração versus sen $\theta$ da ferrita do aço inoxidável super dúplex UNS S32520.

Analogamente, a figura 4.16 e figura 4.17 apresentam o alargamento $(\Delta 2 \theta$ $\cos \theta)$ dos picos em função do sen $\theta$ da austenita para condições encruada e recozidas conforme tabela 3.4, para o aço inoxidável dúplex UNS S31803 e super dúplex UNS S32520, respectivamente. As curvas também são crescentes e aproximadamente lineares. 


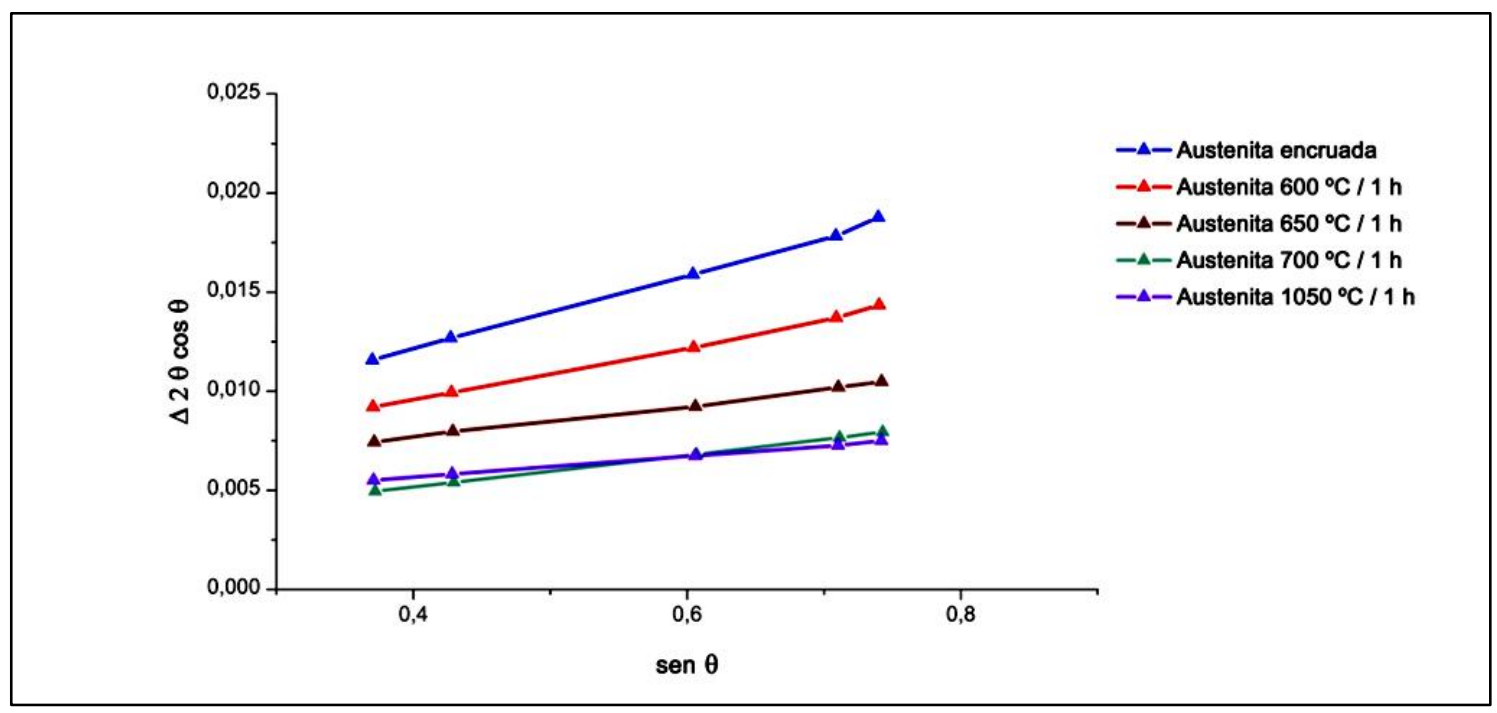

Figura 4.16 - Valores de alargamento dos picos de difração versus sen $\theta$ da austenita do aço inoxidável dúplex UNS S31803.

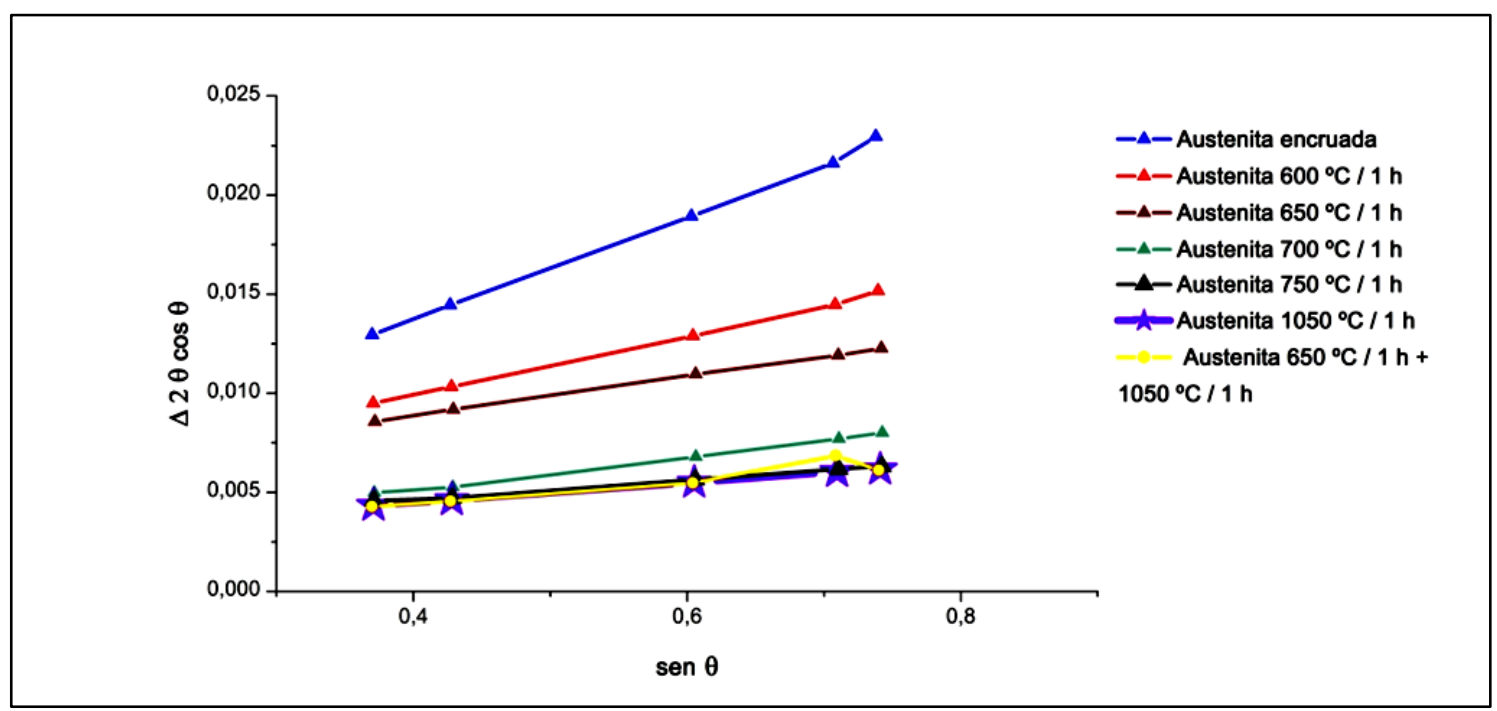

Figura 4.17 - Valores de alargamento dos picos de difração versus sen $\theta$ da austenita do aço inoxidável super dúplex UNS S32520.

Depois de realizada a linearização das curvas, obtem-se o coeficiente angular e a intersecção com o eixo vertical (coeficiente linear), que são utilizados no cálculo [240 - 243] do tamanho de cristalito (D), equação 4.1, e das microdeformações residuais $(\varepsilon)$, equação 4.2 .

D $(\mathrm{nm})=0,9 \lambda /$ (coeficiente linear da reta)

Equação 4.1

$\boldsymbol{\varepsilon}(\%)=($ coeficiente angular $) / 2$ 
$\mathrm{Na}$ tabela 4.5 são apresentados os resultados obtidos com auxílio da equação 4.1 e da equação 4.2 .

Tabela 4.5 - Tamanho de cristalitos (D) e microdeformações residuais $(\varepsilon)$ nas amostras encruada e recozidas conforme Tabela 3.4, para o aços inoxidáveis dúplex e super dúplex.

\begin{tabular}{|c|c|c|c|c|}
\hline \multirow[t]{2}{*}{ Fase } & \multicolumn{2}{|c|}{$\begin{array}{l}\text { Dúplex UNS } \\
\text { S31803 }\end{array}$} & \multicolumn{2}{|c|}{$\begin{array}{c}\text { Super } \\
\text { dúplex UNS } \\
\text { S32520 }\end{array}$} \\
\hline & $D(n m)$ & $\varepsilon(\%)$ & $\begin{array}{c}D \\
(\mathrm{~nm})\end{array}$ & $\begin{array}{c}\varepsilon \\
(\%)\end{array}$ \\
\hline Austenita encruada & 30 & 0,95 & 44 & 1,32 \\
\hline Austenita $600 \stackrel{\circ}{ } \mathrm{C} / 1 \mathrm{~h}$ & 29 & 0,61 & 36 & 0,76 \\
\hline Austenita $650^{\circ} \mathrm{C} / 1 \mathrm{~h}$ & 31 & 0,40 & 28 & 0,49 \\
\hline Austenita $700 \stackrel{\circ}{ } \mathrm{C} / 1 \mathrm{~h}$ & 71 & 0,40 & 77 & 0,41 \\
\hline Austenita $750^{\circ} \mathrm{C} / 1 \mathrm{~h}$ & 38 & 0,22 & 51 & 0,24 \\
\hline Austenita $1050^{\circ} \mathrm{C} / 1 \mathrm{~h}$ & 39 & 0,26 & 56 & 0,25 \\
\hline Austenita $650^{\circ} \mathrm{C} / 1 \mathrm{~h}+1050^{\circ} \mathrm{C} / 1 \mathrm{~h}$ & 51 & 0,20 & 69 & 0,30 \\
\hline Ferrita encruada & 37 & 0,91 & 31 & $\overline{0,81}$ \\
\hline Ferrita $600^{\circ} \mathrm{C}$ & 61 & 0,54 & 56 & 0,55 \\
\hline Ferrita $650^{\circ} \mathrm{C}$ & 45 & 0,39 & 34 & 0,31 \\
\hline Ferrita $700 \stackrel{\circ}{\mathrm{C}}$ & 98 & 0,64 & 36 & 0,17 \\
\hline Ferrita $1050 \stackrel{\circ}{C}$ & 68 & 0,16 & 63 & 0,23 \\
\hline Ferrita $650^{\circ} \mathrm{C} / 1 \mathrm{~h}+1050^{\circ} \mathrm{C} / 1 \mathrm{~h}$ & 58 & 0,20 & 61 & 0,23 \\
\hline
\end{tabular}

Observa-se na tabela 4.5 que o tamanho de cristalitos da austenita encruada é baixo e permanece quase inalterado mesmo com os tratamentos térmicos de 600 e $650 \stackrel{\circ}{\circ}$ por 1 hora para ambos os aços. Nas amostras encruadas, a significativa presença de martensita induzida por deformação pode explicar esse acontecimento. Para tratamentos 600 e $650^{\circ} \mathrm{C}$ por 1 hora, o baixo tamanho de cristalito pode ser relacionado ao baixo coeficiente de difusão da austenita nessas faixas de temperatura.

Para $700 \stackrel{\circ}{\mathrm{C}}$ por 1 hora, martensita induzida por deformação reverte para austenita. Além disso, parte da fase vizinha (ferrita) se transforma em austenita via decomposição eutetóide (sigma + austenita). Nessa faixa de temperatura, já ocorre uma maior difusão na austenita. O rearranjo e a aniquilação de defeitos devido aos 
processos de recuperação e recristalização que estão ocorrendo competitivamente nessa temperatura, fazem com que os cristalitos aumentem significativamente em relação à austenita encruada, para ambos os aços.

A austenita aumentou de tamanho de cristalitos para ambos os aços recozidos diretamente a $1050^{\circ} \mathrm{C}$ por 1 hora, em relação ao material encruado, fato causado pelos já citados processos de recuperação e recristalização. $O$ fato dos tamanhos dos cristalitos do super dúplex estarem significativamente maiores que os do dúplex para essa condição, pode estar relacionado à maior estabilidade da austenita do dúplex, devido à composição química.

Para o tamanho dos cristalitos da austenita dos dois aços, pode-se comparar o efeito do tratamento direto a $1050 \stackrel{\circ}{\circ}$ por 1 hora com o efeito do tratamento intermediário de $650^{\circ} \mathrm{C}$ antecedendo a $1050 \stackrel{\circ}{\circ}$ por 1 hora. $A$ amostra que passou pelo tratamento intermediário tem o tamanho de cristalito maior. Provavelmente, porque nesse caso houve reversão de martensita induzida por deformação para austenita, consequentemente, quando passou para a o tratamento de recristalização a $1050 \stackrel{\circ}{C}$ por 1 hora, a fração de fase magnética dentro da austenita era muito baixa ou inexistente.

Para todos os casos de tratamento da austenita de ambos os aços, a microdeformação residual diminuiu em relação ao material encruado. Conforme esperado, esta diminuição foi maior quanto maior a temperatura de tratamento.

Em se tratando de ferrita, o tratamento térmico de $600^{\circ} \mathrm{C}$ fez com que aumentasse o tamanho de cristalito em relação ao material encruado de ambos os aços. A difusão da ferrita já é significativa nesta temperatura favorecendo os processos de recuperação dessa fase.

Embora a $650^{\circ} \mathrm{C}$ a difusão na ferrita seja ainda maior que no caso anterior, pouco alterou-se no tamanho de cristalito para essa fase nesta temperatura em ambos os aços. O fato da significativa reversão da martensita em austenita que ocorreu na fase vizinha pode ter influenciado nesse aspecto.

A ferrita a $700 \stackrel{\circ}{ } \mathrm{C}$ é bastante instável. Embora possa haver a recristalização nessa fase, competitivamente ela se decompõe em fase sigma e austenita secundária. Para o aço dúplex, onde ainda há uma fração volumétrica de ferrita razoável, os cristalitos aumentaram significativamente de tamanho em relação à ferrita encruada, pelos processos de recuperação e recristalização. A diminuição da microdeformação residual em relação ao material encruado, foi menor que para os 
outros tratamentos. A fase sigma, produto da decomposição da ferrita, pode ter sido responsável por essa microdeformação da ferrita continuar alta no aço dúplex. A ferrita do aço super dúplex diferiu completamente em relação ao dúplex nessa temperatura. Isso deve estar relacionado à sensibilidade da técnica, já que a fração volumétrica de ferrita desse aço foi de apenas $2 \%$ e a precipitação de sigma foi significativamente mais alta que a do dúplex, devido à maior presença de cromo e molibdênio.

Os tratamentos de $1050{ }^{\circ} \mathrm{C}$ na ferrita tanto do dúplex como do super dúplex, favoreceram o aumento do tamanho de cristalito em relação ao material encruado, devido ao alto coeficiente de difusão nessa temperatura proporcionar aniquilação e rearranjo de defeitos por recuperação e recristalização.

Os tratamentos térmicos da ferrita de ambos os aços favorecem a diminuição da microdeformação residual em relação ao material encruado. A diminuição dessa microdeformação, aumenta com o aumento da temperatura, exceto no caso de $700{ }^{\circ} \mathrm{C}$ devido a presença de fase sigma.

A figura 4.18 e figura 4.19 demonstram de maneira gráfica os dados de microdeformação residual expressos na tabela 4.5 para austenita e ferrita do aço inoxidável dúplex UNS S31803 e super dúplex UNS S32520, respectivamente, encruada e nas condições e recozidas citadas na tabela 3.4. 
86

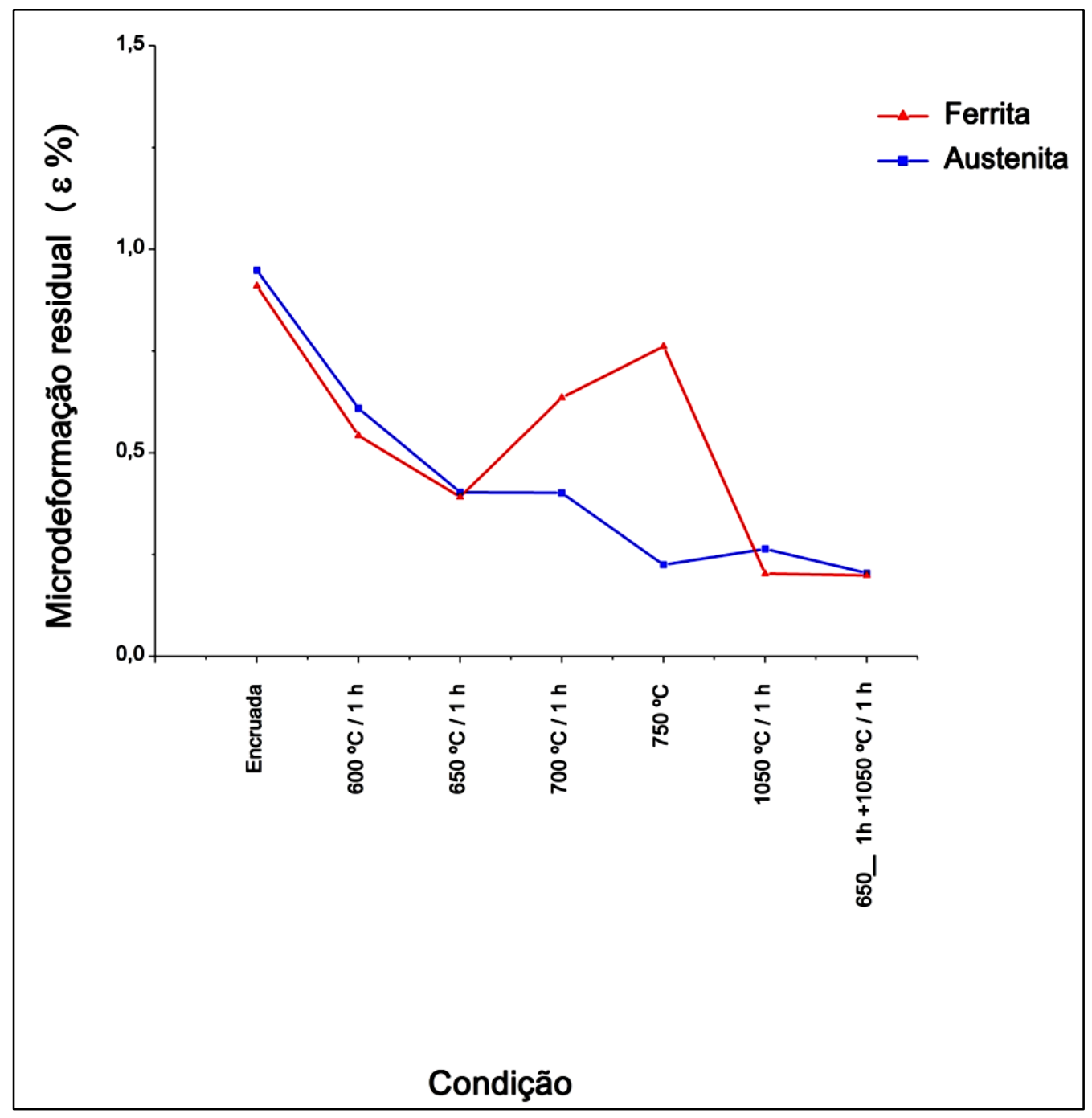

Figura 4.18 - Microdeformação residual da ferrita e austenita nas diversas condições (encruada e tratadas termicamente) do aço inoxidável dúplex UNS S31803. 


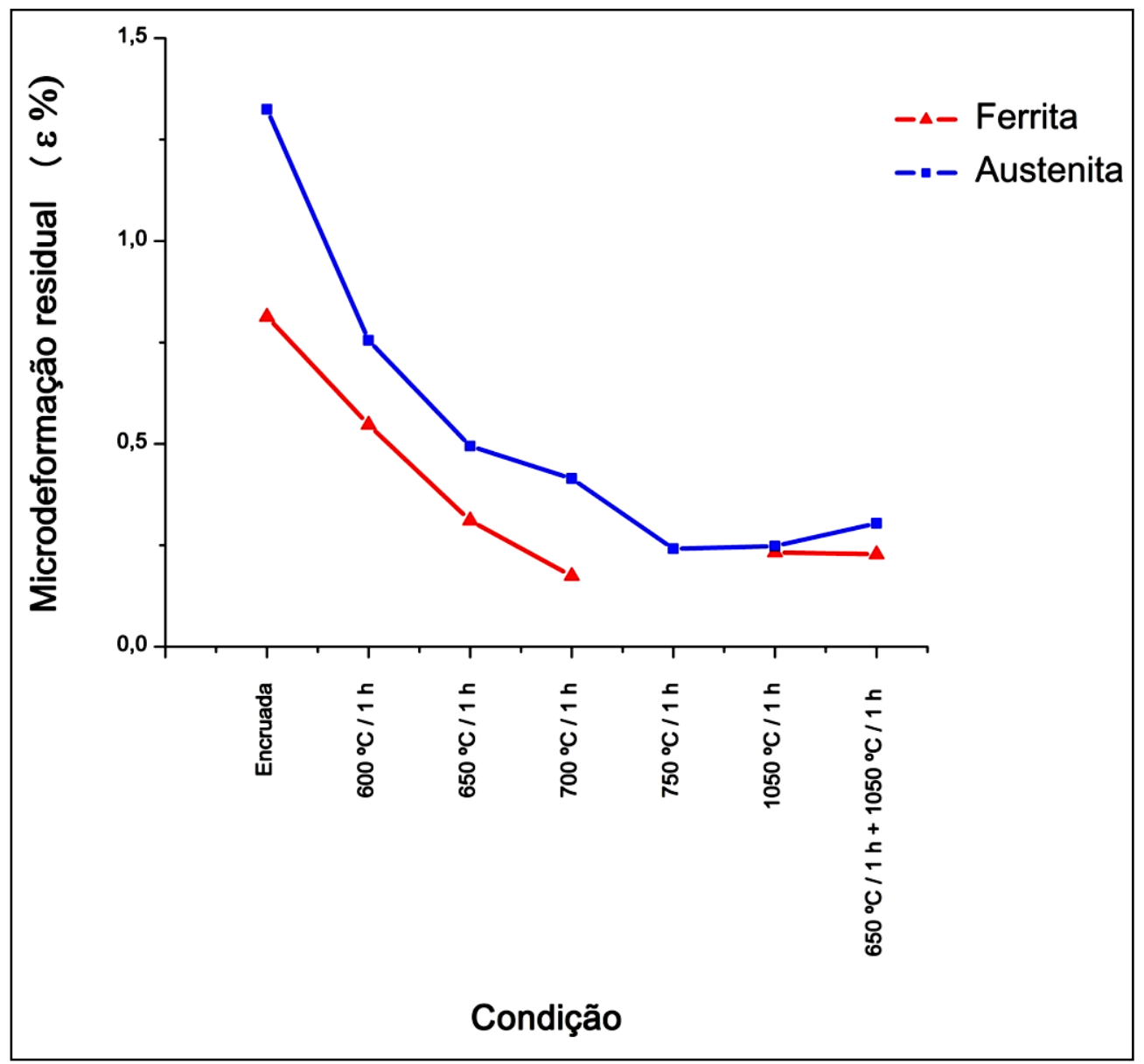

Figura 4.19 - Microdeformação residual da ferrita e austenita nas diversas condições (encruada e tratadas termicamente) do aço inoxidável super dúplex UNS S32520.

A observação da figura 4.18 e figura 4.19 leva a verificar que nas duas fases o tratamento térmico serviu para redução das microdeformações residuais, em relação ao material encruado, exceto para os casos de precipitação de fase sigma, onde a microdeformação da ferrita aumentou. Essa redução se deve a vários mecanismos como recuperação, recristalização, dependendo da temperatura, e no caso específico da austenita, a reversão da martensita induzida por deformação.

\subsection{Resultados de raios $X$ e determinação da microdeformação residual e tamanho de cristalitos das chapas laminadas dos aços inoxidáveis dúplex UNS S31803 e super dúplex UNS S32520}

A figura 4.20 representa a figura de difração do aço inoxidável dúplex UNS S31803, no estado como recebido (nominalmente solubilizado), com $50 \%$ de 
laminação e com 93 \% de laminação, conforme a legenda de cores. Estão indicados na figura os planos da austenita $A-(h k l)$ e da ferrita $F-(h k l)$.

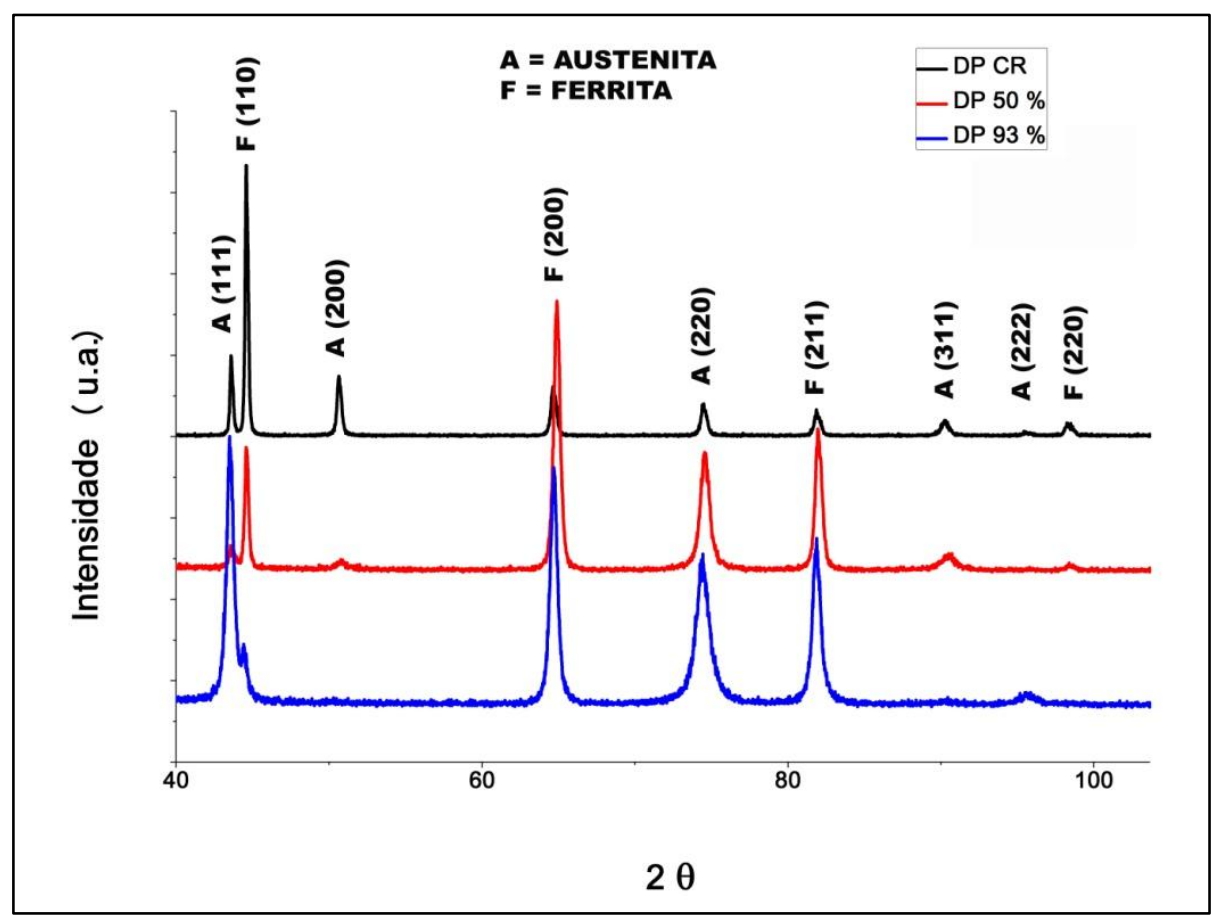

Figura 4.20 - Figuras de difração do aço inoxidável dúplex UNS S31803, no estado como recebido (nominalmente solubilizado), com 50 \% de laminação e com $93 \%$ de laminação, conforme a legenda de cores. Radiação CuKa.

Nota-se que a laminação provoca uma mudança significativa nos picos de difração. Para 50 \% de laminação, aumentou a intensidade relativa dos picos (200) e (211) da ferrita e (220) da austenita, enquanto diminui a intensidade relativa dos picos (110) da ferrita e (111) da austenita em relação ao material como recebido. Para $93 \%$ de laminação as mudanças foram quase as mesmas, pois aumentou significativamente a intensidade relativa dos picos (200) e (211) da ferrita e (111), (220) e (222) da austenita. A diferença para a laminação de $50 \%$ é que o pico (110) da ferrita diminuiu e o (111) da austenita aumentou. Além destas observações, notase que os picos (220) da ferrita e (200) e (311) da austenita praticamente desapareceram. Estas fortes mudanças na aparência das figuras de difração são causadas pela mudança na textura cristalográfica do material, somadas às possíveis transformações de fase induzidas por deformação na austenita.

Os tratamentos térmicos individuais de $600 \stackrel{\circ}{\circ}$ e $650 \stackrel{\circ}{\circ}$ por 1 hora (objetivando reversão de possível matensita induzida por deformação, como descrito nos métodos) foram empregados na amostra com 50 \% de redução por laminação e 
a representa os picos de difração para cada amostra conforme a legenda de cores, comparadas com a amostra como recebida (nominalmente solubilizada).

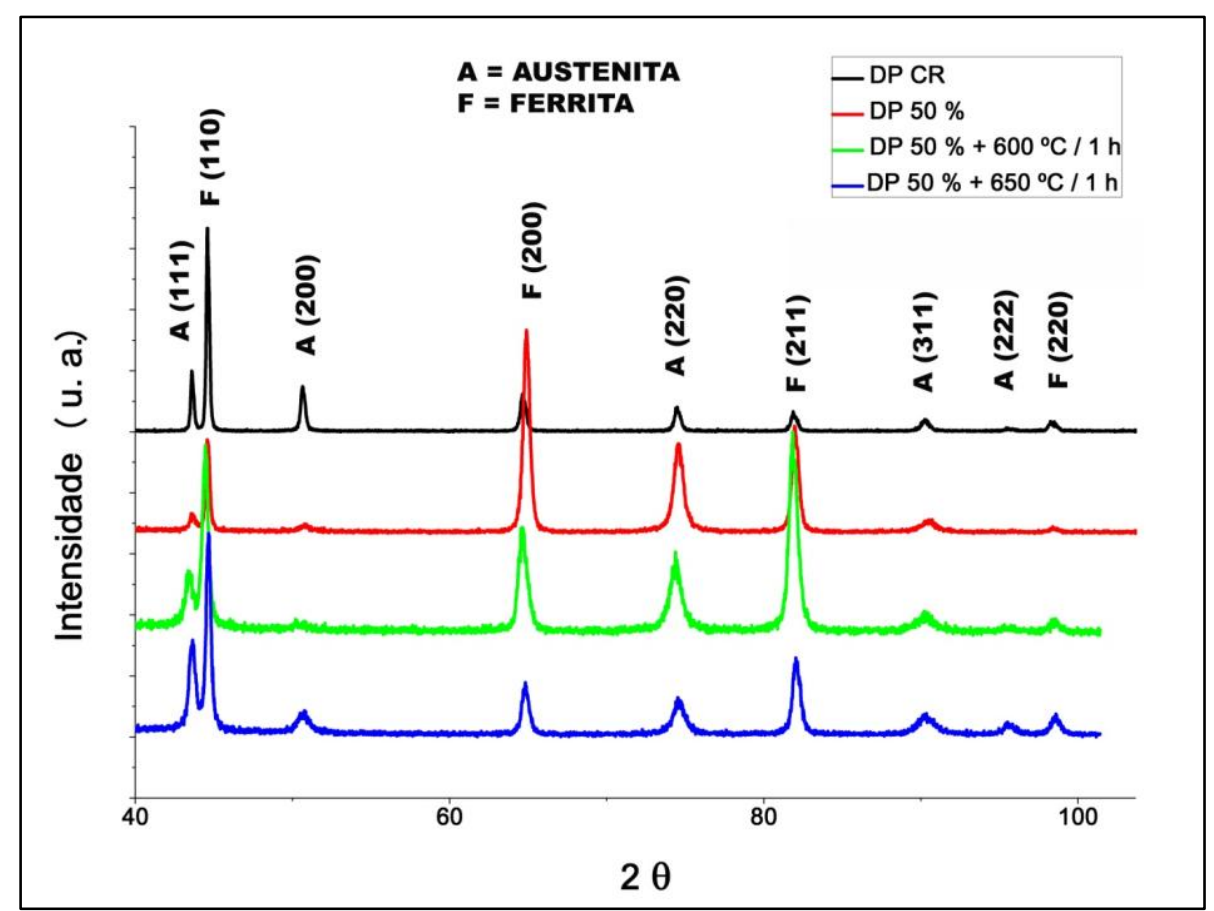

Figura 4.21 - Figuras de difração do aço inoxidável dúplex UNS S31803, no estado como recebido (nominalmente solubilizado), com $50 \%$ de laminação, bem como tratamentos térmicos individuais de 600 e $650 \stackrel{\circ}{\circ}$ por 1 hora a partir da condição deformada, conforme a legenda de cores. Radiação CuKa.

Após os tratamentos térmicos de $600{ }^{\circ} \mathrm{C}$ e $650{ }^{\circ} \mathrm{C}$ por 1 hora há diminuição na intensidade relativa daqueles picos que foram alterados pela redução de $50 \%$ por laminação. A amostra que foi tratada a $650 \stackrel{\circ}{\circ}$ por 1 hora (linha azul no gráfico) tem seus picos de difração semelhantes aos da amostra como recebida (linha preta no gráfico). Porém, alguns picos de ferrita como o (200) e (211) continuam ligeiramente mais intensos. Isto pode indicar a permanência de uma fraca textura provocada pela laminação e/ou uma reversão incompleta da martensita induzida por deformação para austenita.

Os tratamentos térmicos individuais de $600 \stackrel{\circ}{\circ}$ e $650 \stackrel{\circ}{\circ}$ por 1 hora foram empregados na amostra com 93 \% de redução por laminação e a representa os picos de difração para cada amostra conforme a legenda de cores. 


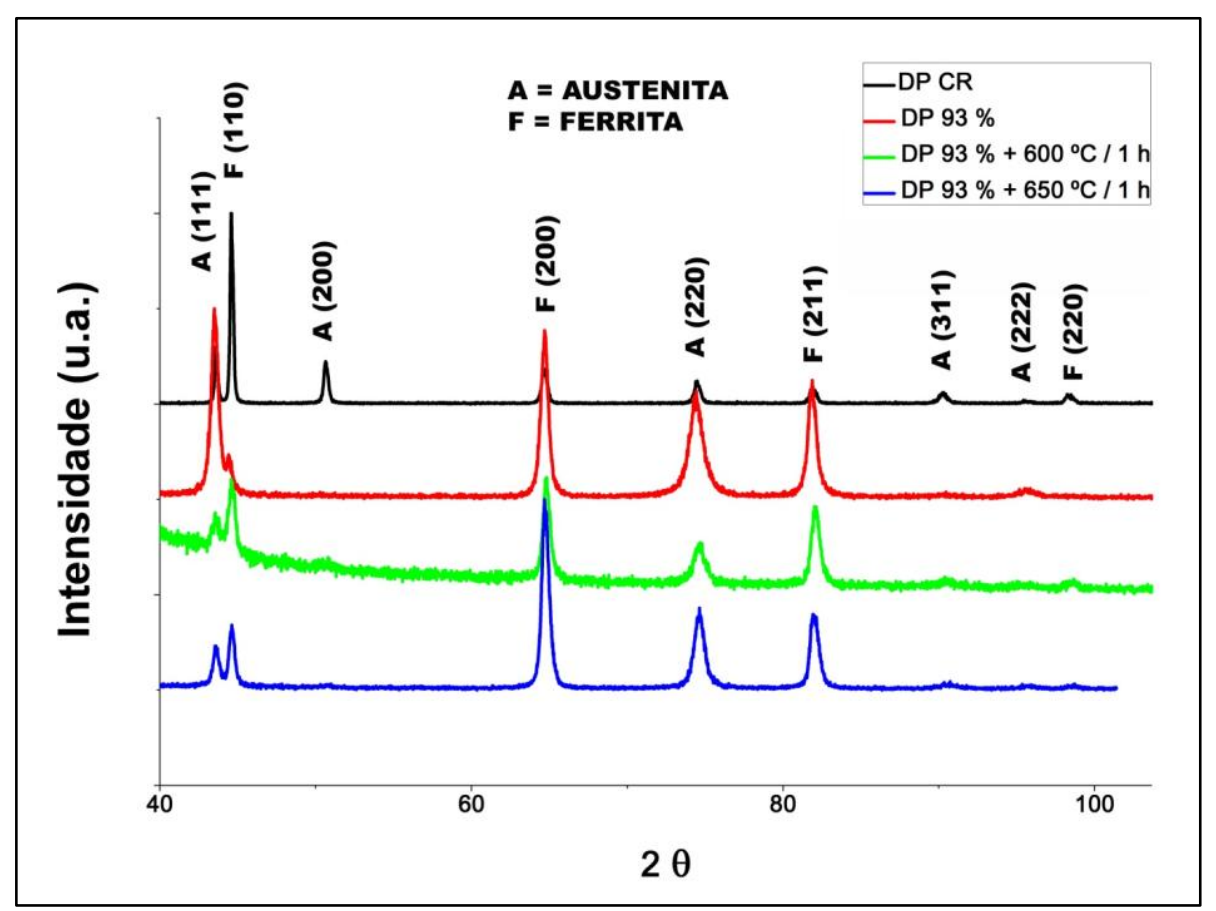

Figura 4.22 - Figuras de difração do aço inoxidável dúplex UNS S31803, no estado como recebido (nominalmente solubilizado), com $93 \%$ de laminação, bem como tratamentos térmicos individuais de 600 e $650 \stackrel{\circ}{\circ}$ por 1 hora a partir da condição deformada, conforme a legenda de cores. Radiação CuKa.

Observando as linhas verde e azul do gráfico, que representam os tratamentos de 600 e $650 \stackrel{\circ}{\circ}$ por 1 hora, respectivamente, a partir da amostra deformada por 93 \% de redução por laminação, nota-se a permanência de uma forte diferença na intensidade relativa dos picos (200) e (211) da ferrita e (220) da austenita em relação ao material nominalmente solubilizado (linha preta do gráfico), indicando uma mudança definitiva na orientação preferencial dos grãos para este grau de deformação.

Da mesma forma, mudanças nas intensidades relativas dos picos de difração são observadas pela laminação do aço inoxidável super dúplex, conforme figura 4.23 . 


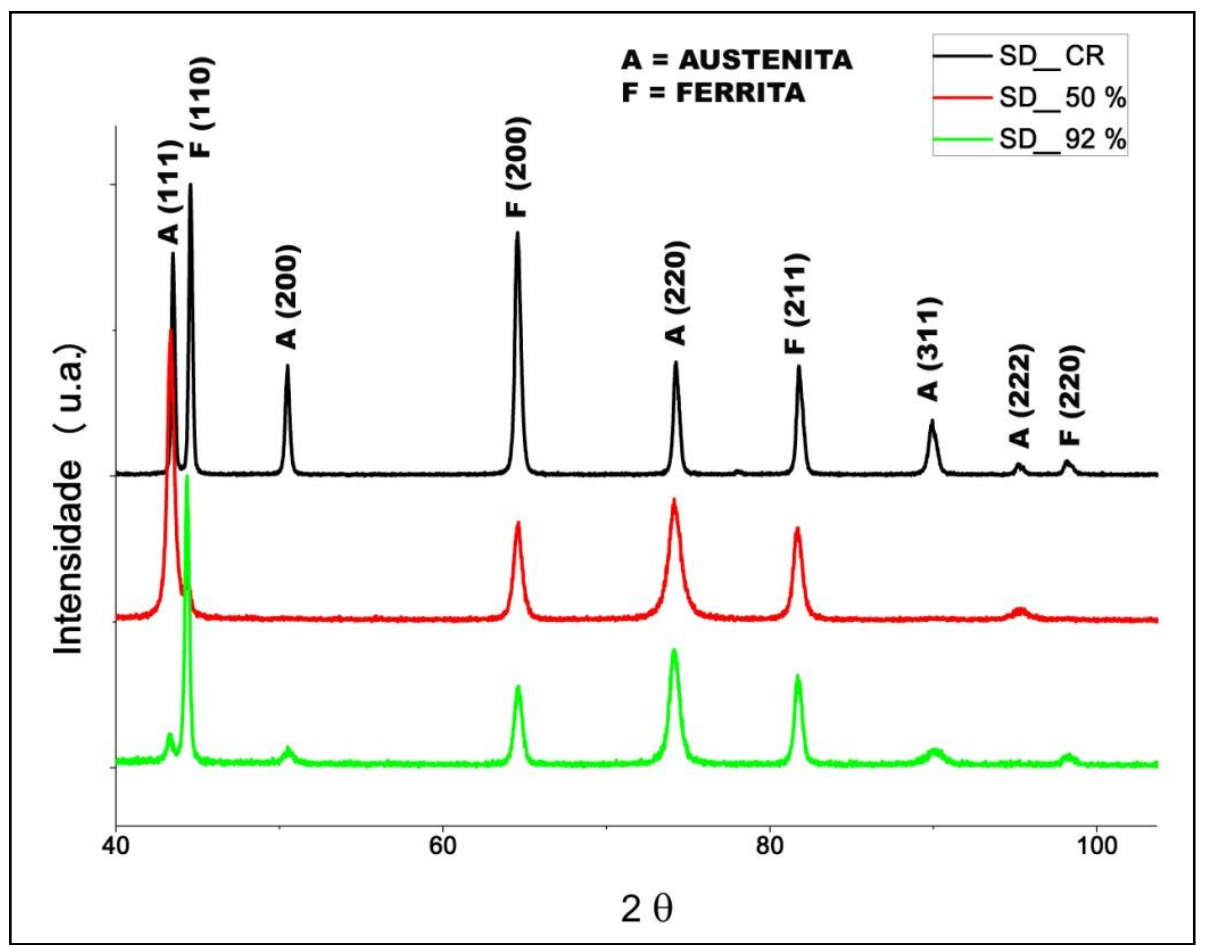

Figura 4.23 - Figuras de difração do aço inoxidável super dúplex UNS S32520, no estado como recebido (nominalmente solubilizado), com 50 \% de laminação e com $92 \%$ de laminação, conforme a legenda de cores. Radiação CuKa.

Nota-se que diminuem os picos (110) e (200) da ferrita, desaparecendo tanto o picos (220) da ferrita quanto os picos (200) e (311) da austenita diminui para a 50 $\%$ de laminação. Ainda nessa condição, a intensidade relativa do pico (111) da austenita aumenta bastante.

Para $90 \%$ de laminação, a alteração é ainda diferente. Enquanto o pico (200) da austenita voltou a aparecer, o pico (111) dessa mesma austenita diminuiu significativamente sua intensidade relativa enquanto o pico (110) da ferrita teve um aumento na intensidade.

$\mathrm{Na}$ figura 4.24 é mostrado o resultado dos tratamentos térmicos individuais de 600 e $650 \stackrel{\circ}{\circ}$ por 1 hora na amostra previamente deformada com $50 \%$ de redução por laminação. 


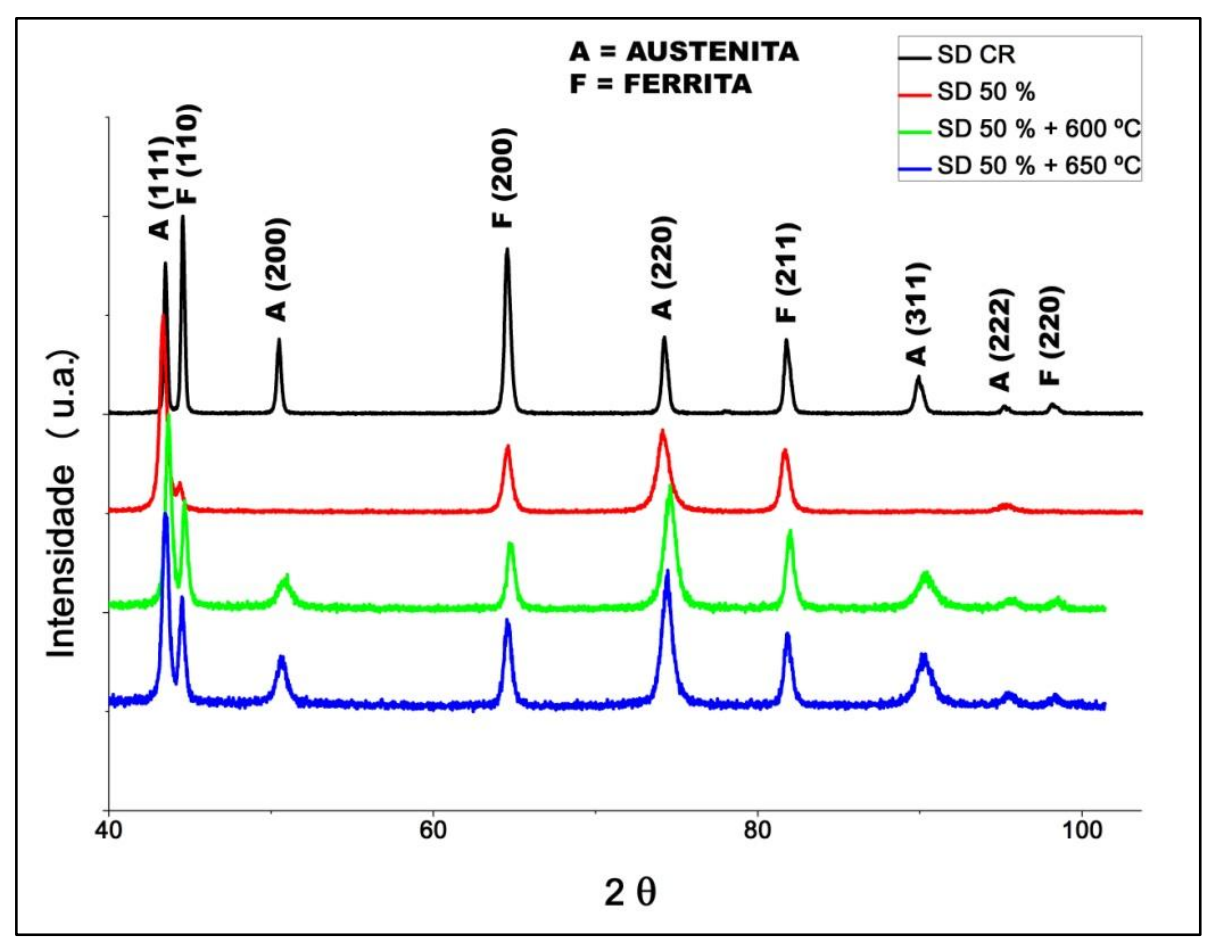

Figura 4.24 - Figuras de difração do aço inoxidável super dúplex UNS S32520, no estado como recebido (nominalmente solubilizado), com $50 \%$ de laminação, bem como tratamentos térmicos individuais de 600 e $650{ }^{\circ} \mathrm{C}$ por 1 hora a partir da condição deformada, conforme a legenda de cores. Radiação CuKa.

Nota-se que os tratamentos de 600 e $650^{\circ} \mathrm{C}$ por 1 hora foram capazes de conduzir a amostra para uma condição similar ao material inicial, com pequenas variações nas intensidades relativas dos picos.

Na figura 4.25 é mostrado o resultado dos tratamentos térmicos individuais de 600 e $650 \stackrel{\circ}{\circ}$ por 1 hora na amostra previamente deformada com $92 \%$ de redução por laminação. 


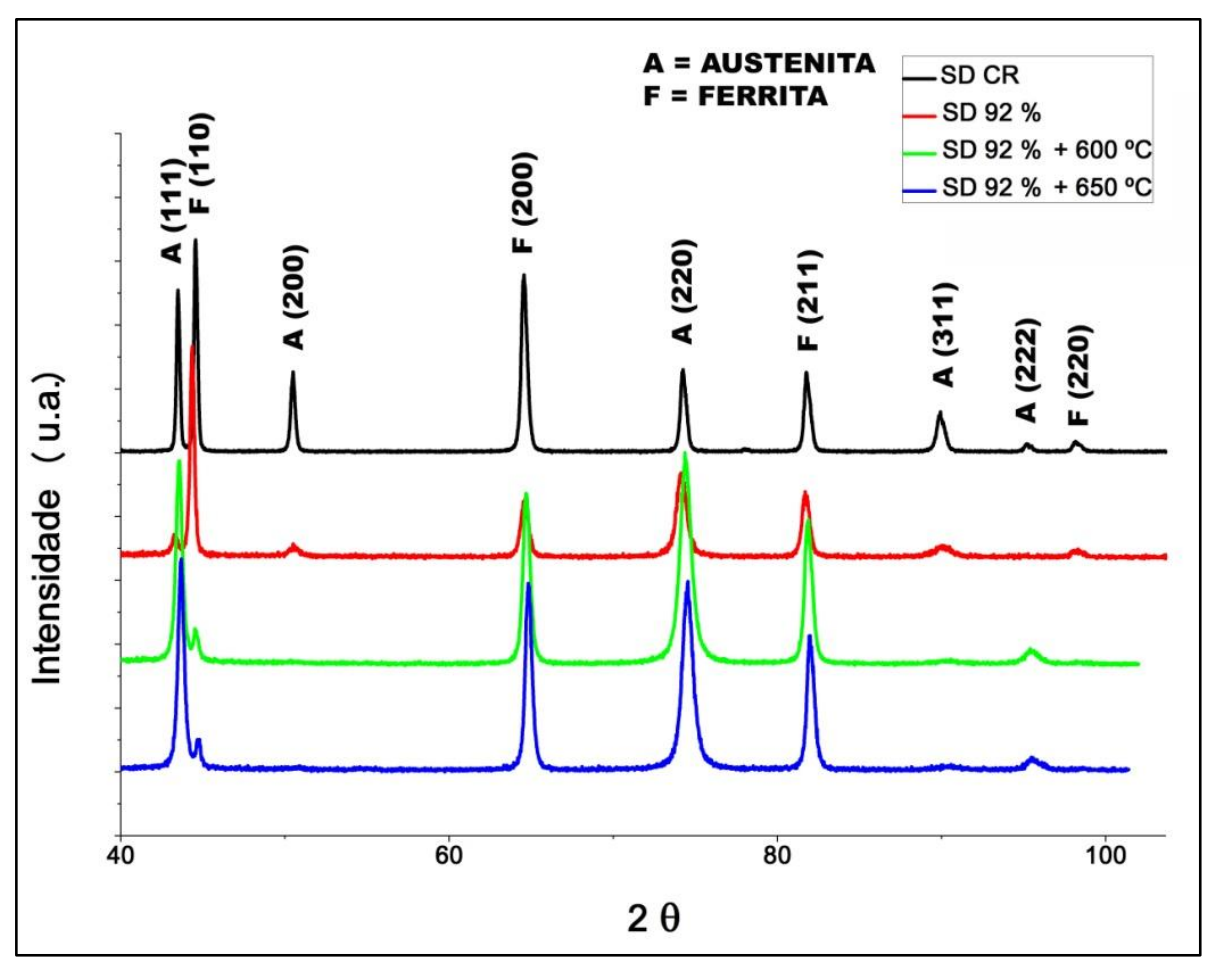

Figura 4.25 - Figuras de difração do aço inoxidável super dúplex UNS S32520, no estado como recebido (nominalmente solubilizado), com $92 \%$ de laminação, bem como tratamentos térmicos individuais de 600 e $650{ }^{\circ} \mathrm{C}$ por 1 hora a partir da condição deformada, conforme a legenda de cores. Radiação CuKa.

Os tratamentos térmicos nas amostras de aço inoxidável super dúplex previamente laminadas a $92 \%$, resultam em intensidades completamente diferentes do material inicial, um forte indicativo de que a combinação entre deformação e recozimento alterou significativamente a textura cristalográfica do material.

Seguindo o mesmo raciocínio usado para a análise dos cavacos, os dados de difração passaram por um refinamento matemático de Rietveld e foram realizadas medidas de alargamento de pico causadas pela deformação, bem como após os tratamentos térmicos. A partir das medidas do alargamento dos picos, foram calculados o tamanho de cristalitos (subgrão) e microdeformações residuais das amostras deformadas e tratadas termicamente por 600 e $650 \stackrel{\circ}{C}$ por 1 hora em ambos os aços. 
Tabela 4.6 - Tamanho de cristalitos e microdeformações residuais nas amostras encruada e recozidas conforme Tabela 3.4, para o aços inoxidáveis dúplex e super dúplex.

\begin{tabular}{|c|c|c|c|c|}
\hline \multirow[t]{2}{*}{ Fase } & \multicolumn{2}{|c|}{$\begin{array}{l}\text { Dúplex UNS } \\
\text { S31803 }\end{array}$} & \multicolumn{2}{|c|}{$\begin{array}{c}\text { Super } \\
\text { dúplex UNS } \\
\text { S32520 }\end{array}$} \\
\hline & $\mathrm{D}(\mathrm{nm})$ & $\varepsilon(\%)$ & $\begin{array}{c}\mathrm{D} \\
(\mathrm{nm})\end{array}$ & $\begin{array}{c}\varepsilon \\
(\%)\end{array}$ \\
\hline Austenita como recebida & 84 & 0,41 & 122 & 0,41 \\
\hline Austenita def. $50 \%$ & 26 & 0,43 & 34 & 0,70 \\
\hline Austenita def. $50 \%+600 \stackrel{\circ}{\circ} / 1 \mathrm{~h}$ & 14 & 0,15 & 43 & 0,80 \\
\hline Austenita def. $50 \%+650{ }^{\circ} \mathrm{C} / 1 \mathrm{~h}$ & 32 & 0,64 & 22 & 0,22 \\
\hline Austenita def. 90\% & 28 & 0,78 & 40 & 0,60 \\
\hline Austenita def. $\sim 90 \%+600 \stackrel{\circ}{C} / 1 \mathrm{~h}$ & 15 & 0,21 & 30 & 0,58 \\
\hline Austenita def. $\sim 90 \%+650 \stackrel{\circ}{C} / 1 \mathrm{~h}$ & 55 & 0,92 & 47 & 0,67 \\
\hline Ferrita como recebida & 140 & 0,40 & 236 & 0,48 \\
\hline Ferrita def. $50 \%$ & 76 & 0,47 & 49 & 0,51 \\
\hline Ferrita def. $50 \%+600 \stackrel{\circ}{ } \mathrm{C} / 1 \mathrm{~h}$ & 26 & 0,21 & 34 & 0,22 \\
\hline Ferrita def. $50 \%+650 \stackrel{\circ}{ } \mathrm{C} / 1 \mathrm{~h}$ & 54 & 0,39 & 38 & 0,22 \\
\hline Ferrita def. 90\% & 43 & 0,48 & 53 & 0,50 \\
\hline Ferrita def. $\sim 90 \%+600 \stackrel{\circ}{\circ} \mathrm{C} / 1 \mathrm{~h}$ & 26 & 0,22 & 52 & 0,41 \\
\hline Ferrita def. $\sim 90 \%+650 \stackrel{\circ}{\circ} / 1 \mathrm{~h}$ & 26 & 0,21 & 65 & 0,42 \\
\hline
\end{tabular}

A figura $4.26 \mathrm{e}$ 
figura 4.27 ilustram de maneira gráfica as microdeformações residuais dos aços inoxidáveis dúplex e super dúplex, respectivamente, em diferentes condições de laminação.

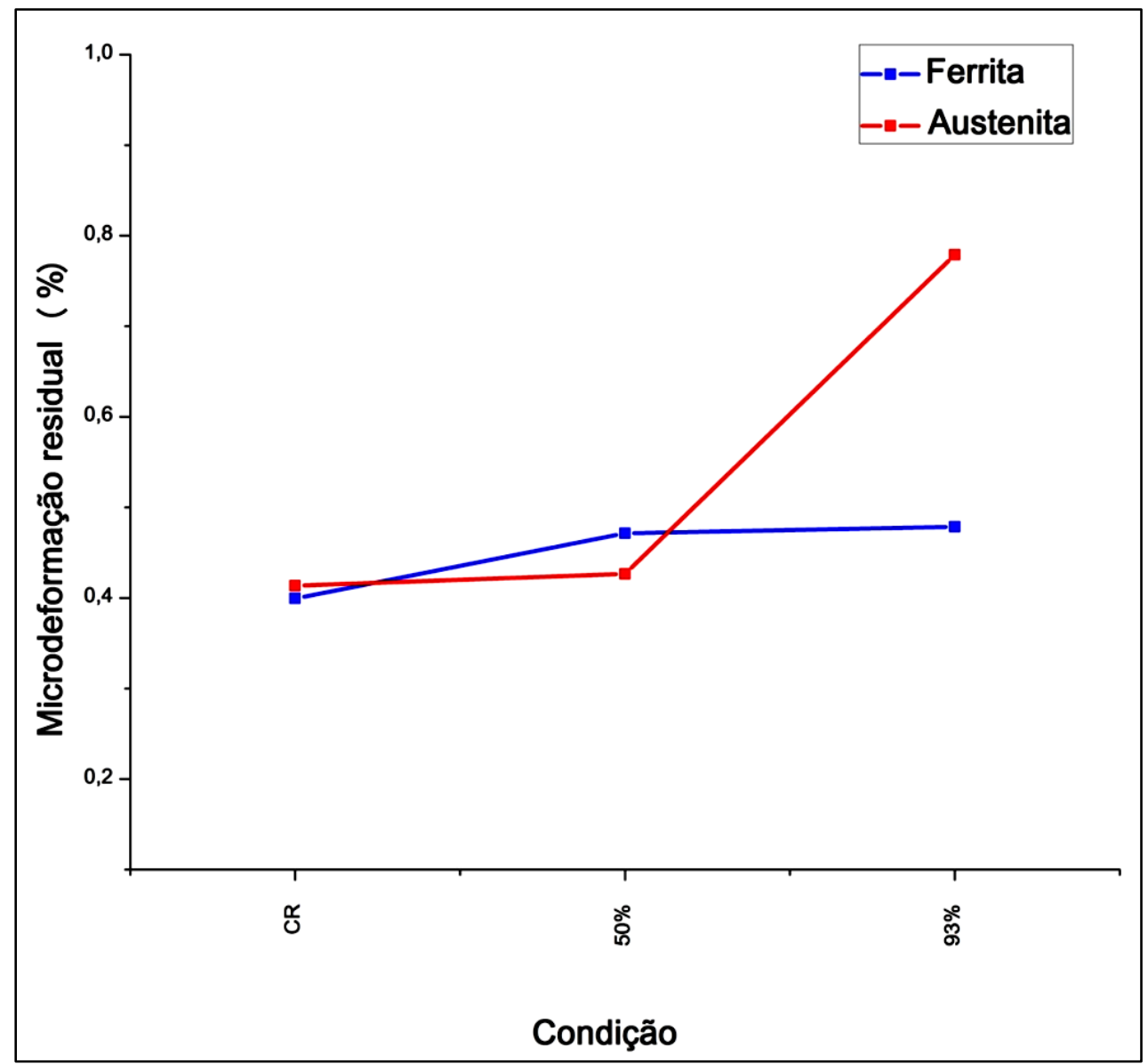

Figura 4.26 - Microdeformação residual da ferrita e austenita do aço inoxidável dúplex UNS S31803 em diferentes condições de laminação comparados com o material como recebido (nominalmente solubilizado). 


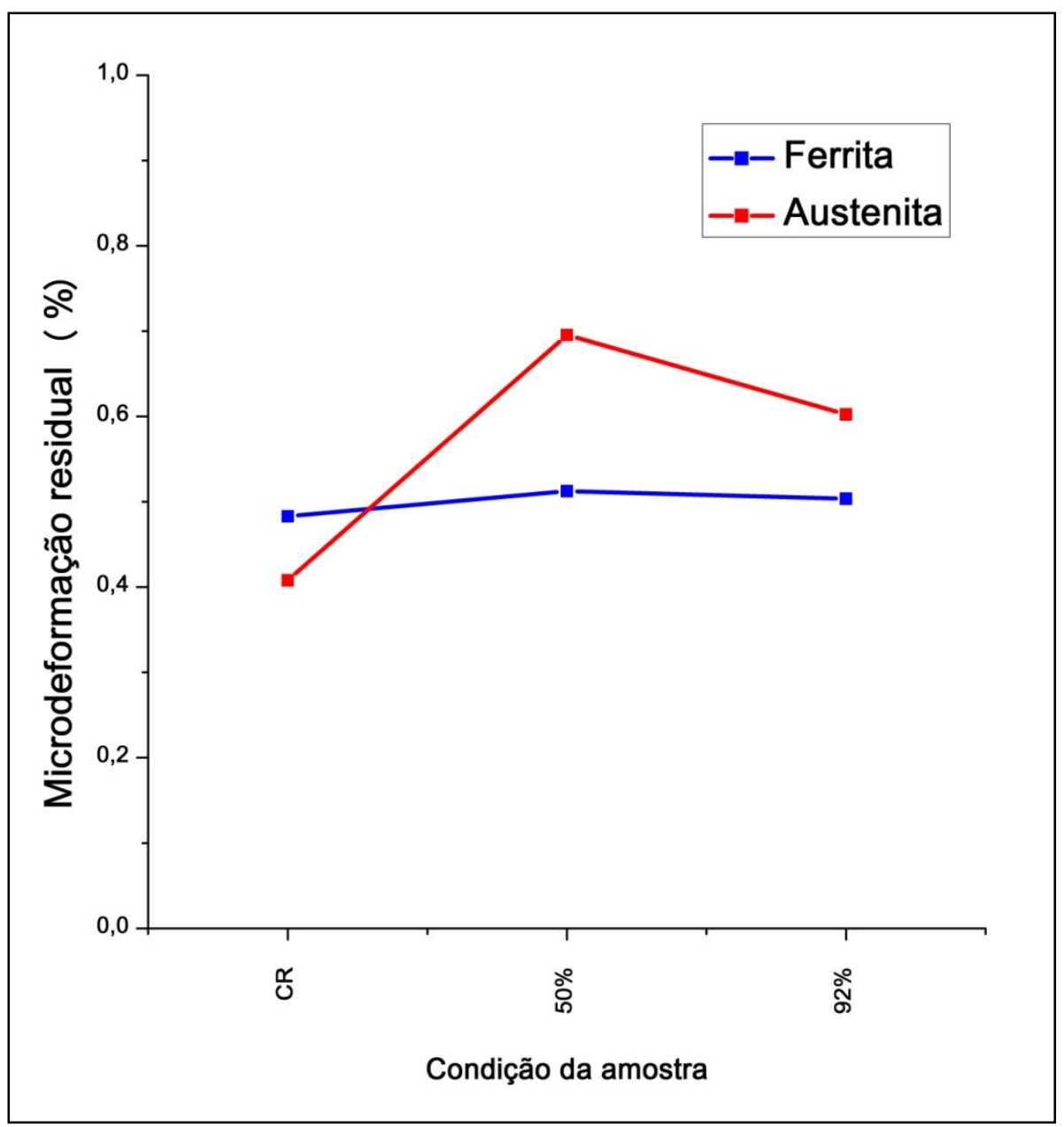

Figura 4.27 - Microdeformação residual da ferrita e austenita do aço inoxidável dúplex UNS S31803 em diferentes condições de laminação comparados com o material como recebido (nominalmente solubilizado).

Nota-se que ao deformar os aços, aumenta-se a a microdeformação residual e diminui-se o tamanho de cristalito (sub-grão) da austenita. Para ambos os aços, altíssimas deformações (próximas a 90 \% de redução) resultam em austenitas com microdeformações residuais elevadas.

Para reduções de 50 \% em laminação onde a deformação é mais moderada, a deformação residual do dúplex é relativamente menor que a do super dúplex.

Ao analisar os efeitos da deformação na ferrita, nota-se que no dúplex, quanto maior a deformação, menor o tamanho de cristalito (subgrão) e com pequeno aumento na microdeformação residual, conforme figura 4.26. Já no super dúplex a 
deformação muito alta (aproximadamente $90 \%$ ), o tamanho de cristalito é muito próximo da deformação de $50 \%$ e o aumento na microdeformação residual também é muito pequeno (vide

figura 4.27).

A figura 4.28 e figura 4.29 ilustram de maneira gráfica o efeito dos tratamentos térmicos de 600 e $650 \stackrel{\circ}{\circ}$ por 1 hora quanto às microdeformações residuais dos aços inoxidáveis dúplex e super dúplex, respectivamente, em amostras previamente deformadas de 50 \% de redução por laminação. 


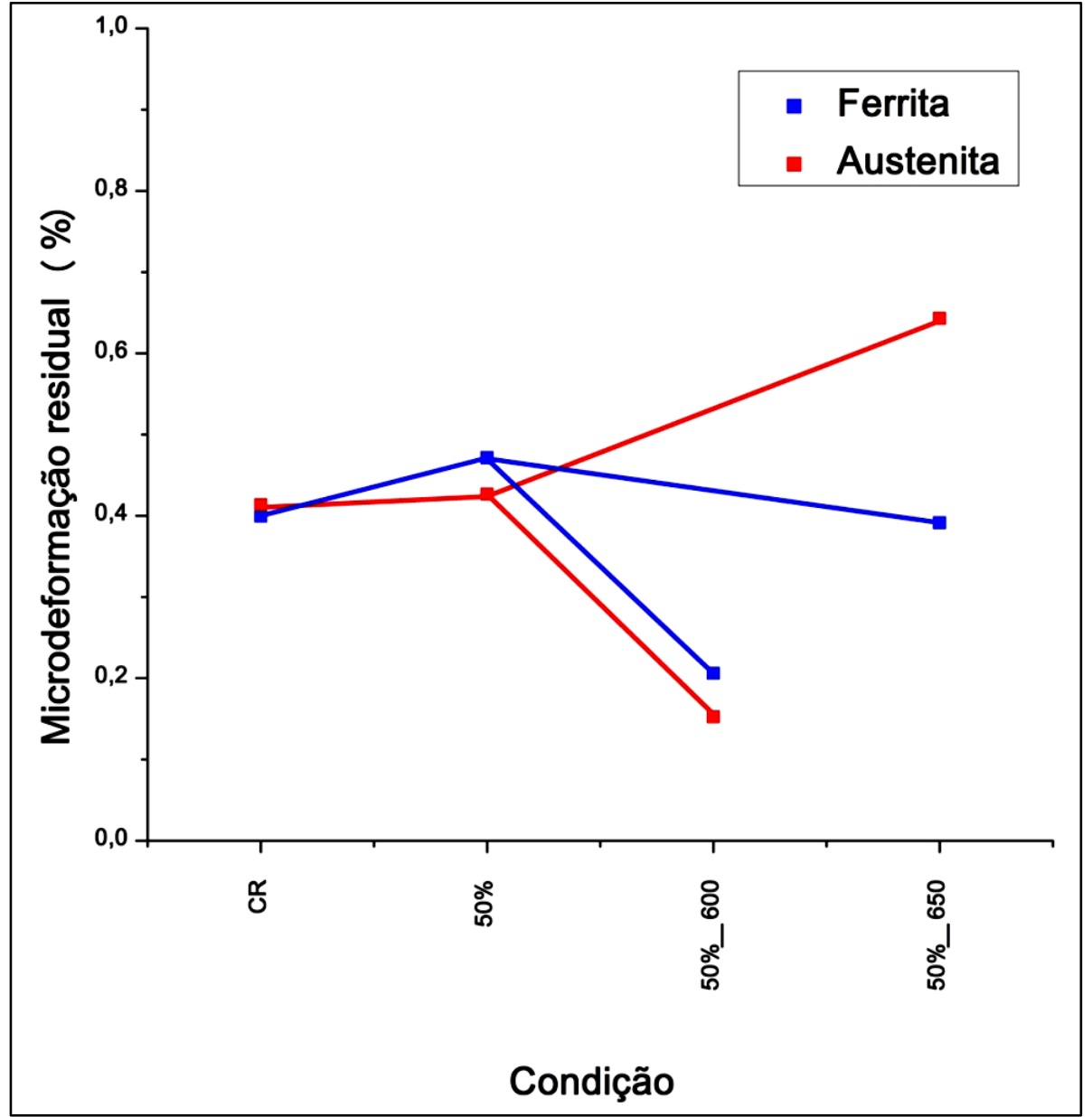

Figura 4.28 - Efeito da temperatura de tratamento térmico de 600 e $650 \stackrel{\circ}{\circ} \mathrm{C}$ por 1 hora na microdeformação residual da austenita e ferrita previamente deformadas de $50 \%$ de redução por laminação do aço inoxidável dúplex UNS S31803. 


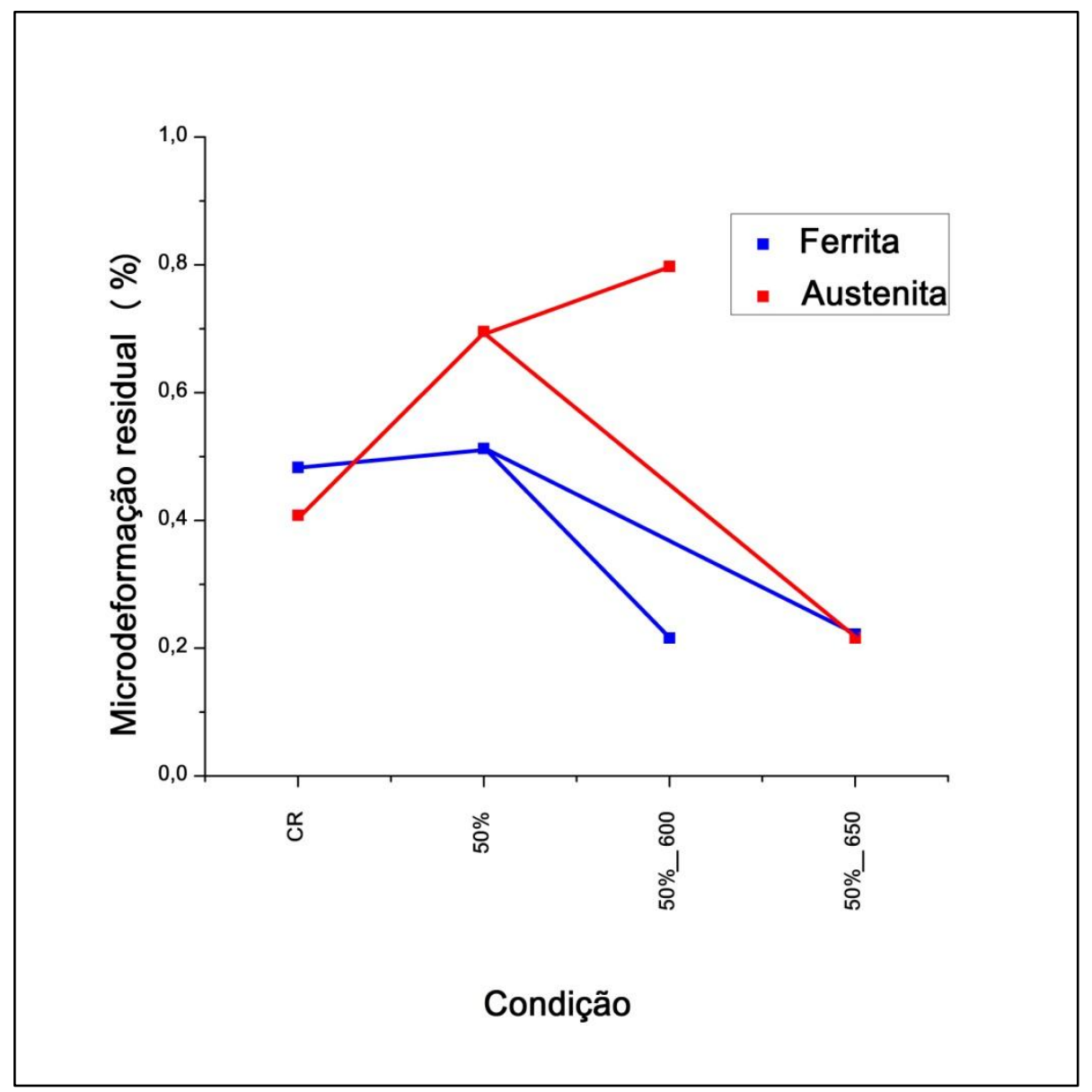

Figura 4.29 - Efeito da temperatura de tratamento térmico de 600 e $650 \stackrel{\circ}{\circ} \mathrm{C}$ por 1 hora na microdeformação residual da austenita e ferrita previamente deformadas de $50 \%$ de redução por laminação do aço inoxidável super dúplex UNS S32520.

Quanto ao efeito dos tratamentos térmicos na austenita dos aços deformados com reduções de $50 \%$ por laminação, nota-se que $600{ }^{\circ} \mathrm{C}$ por 1 hora, na austenita do dúplex há redução da microdeformação residual. Enquanto isto, esta temperatura foi insuficiente para reduzir as microdeformações residuais na austenita do super dúplex.

O efeito do tratamento a $650 \stackrel{\circ}{\circ} \mathrm{C}$ por 1 hora na austenita dos dois aços deformados com $50 \%$ de laminação é muito distinto. No super dúplex há diminuição da microdeformação residual, sendo uma evidência importante de que não ocorre nenhuma reversão de fase e sim, um possível início de recuperação da austenita. Já no dúplex, essa temperatura provoca um aumento na microdeformação residual, fato que pode estar relacionado com a reversão da martensita induzida por deformação para austenita. Essa reversão é acompanhada por uma contração de aproximadamente $1,5 \%$ no volume, gerando assim, este aumento nos valores de microdeformação residual. 
A partir da ferrita deformada a 50 \% de redução por laminação, o tratamento térmico reduz a microdeformação residual tanto do dúplex quanto do super dúplex. A $600^{\circ} \mathrm{C}$ por 1 hora, a diminuição da microdeformação residual no dúplex é maior que a $650 \stackrel{\circ}{\circ}$ por 1 hora (apesar do coeficiente de difusão desta última temperatura ser maior). Este fator pode ser mais uma evidência de que está ocorrendo reversão de martensita induzida por deformação para a austenita, pois a $650 \stackrel{\circ}{\circ}$ esta reversão é mais acentuada que a $600 \stackrel{\circ}{\circ}$. Embora este fenômeno ocorra na fase vizinha, campos de tensão são gerados na amostra, competindo com o alívio das tensões promovido pela recuperação e recristalização da ferrita. Outro indício desta suposição é que no super dúplex (onde não houve transformação martensítica), o tratamento a $650 \stackrel{\circ}{\mathrm{C}}$ por 1 hora promove a diminuição da microdeformação residual, sugerindo que a recuperação e recristalização da ferrita não é atrapalhada por uma eventual mudança transformação de fase na vizinhança (austenita).

A figura 4.30 e figura 4.31 ilustram de maneira gráfica 0 efeito dos tratamentos térmicos de 600 e $650{ }^{\circ} \mathrm{C}$ por 1 hora quanto às microdeformações residuais dos aços inoxidáveis dúplex e super dúplex, respectivamente, em amostras previamente deformadas de aproximadamente $90 \%$ de redução por laminação. 


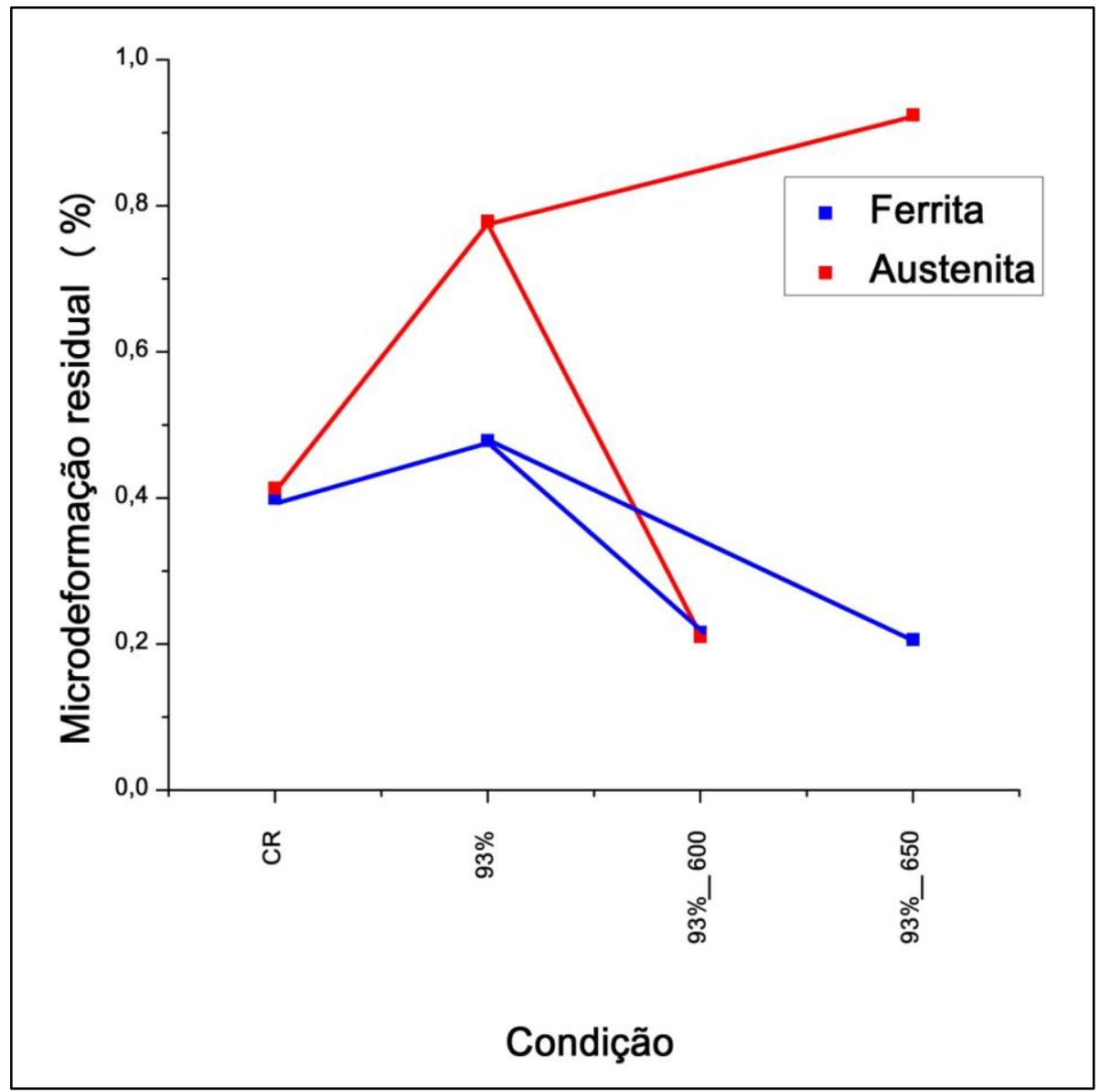

Figura 4.30 - Efeito da temperatura de tratamento térmico de 600 e $650 \stackrel{\circ}{\circ} \mathrm{C}$ por 1 hora na microdeformação residual da austenita e ferrita previamente deformadas de $93 \%$ de redução por laminação do aço inoxidável dúplex UNS S31803. 


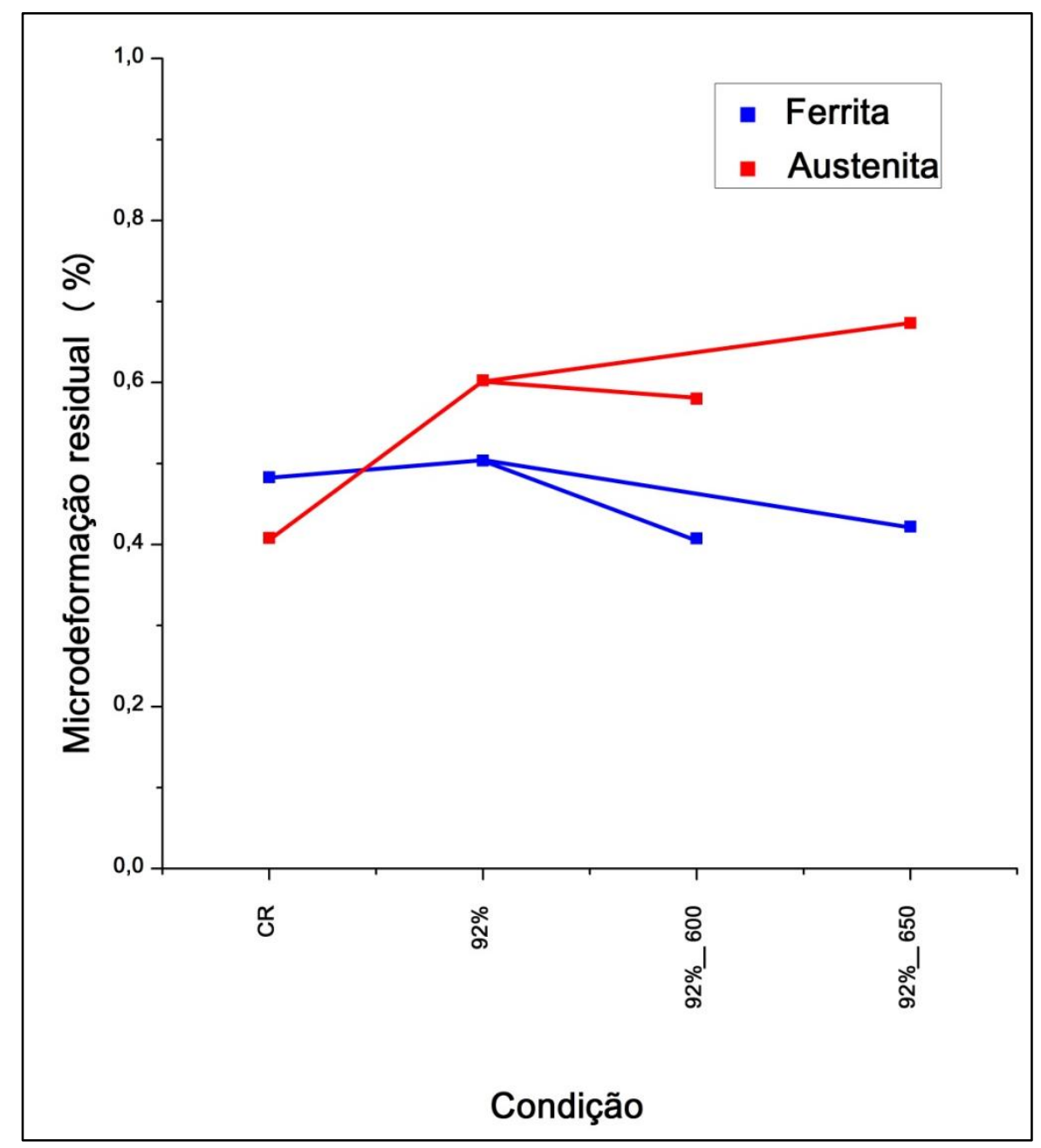

Figura 4.31 - Efeito da temperatura de tratamento térmico de 600 e $650 \stackrel{\circ}{\circ} \mathrm{C}$ por 1 hora na microdeformação residual da austenita e ferrita previamente deformadas de $50 \%$ de redução por laminação do aço inoxidável super dúplex UNS S32520.

Para tratamentos térmicos a partir da deformação de $90 \%$ de redução por laminação, a temperatura de a $600{ }^{\circ} \mathrm{C}$ provoca redução da microdeformação residual na austenita do dúplex. Já a temperatura de $650 \stackrel{\circ}{\circ}$ aumenta a microdeformação residual, fato possivelmente provocado pela reversão da martensita induzida por deformação para austenita e consequente campos de tensões que acompanham esta transformação (contração volumétrica de $1,5 \%$, aproximadamente). Na austenita do super dúplex nas mesmas condições de laminação, a alteração das microdeformações residuais são pouco significativas com ambos os tratamentos térmicos.

Quanto ao comportamento da ferrita do dúplex e do super dúplex, ocorrem algumas diferenças importantes. Apesar da energia acumulada ser grande e uma redução na microdeformação residual ocorrer tanto para 600 quanto $650 \stackrel{\circ}{\circ}$ por 1 hora, não há crescimento de cristalito no dúplex. Este fato pode estar relacionado 
com a competição da recuperação/recristalização da ferrita com a reversão da martensita induzida por deformação para austenita na fase vizinha.

Já no super dúplex, o tratamento térmico de $650^{\circ} \mathrm{C}$ por 1 hora além de diminuir a microdeformação residual, promove um aumento do tamanho do cristalito, sugerindo que a recuperação/recristalização da ferrita ocorre sem que haja competição com nenhuma reversão de fase na vizinhança.

\subsection{Comparação entre as microdeformações residuais das amostras deformadas por limagem e laminação}

Depois de determinadas as microdeformações residuais das amostras dos dois aços, pode-se comparar os valores entre os processos de limagem e laminação. A figura 4.32 até figura 4.35 comparam, em relação aos processos de deformação, os valores de microdeformações residuais de austenita e ferrita para ambos os aços. 


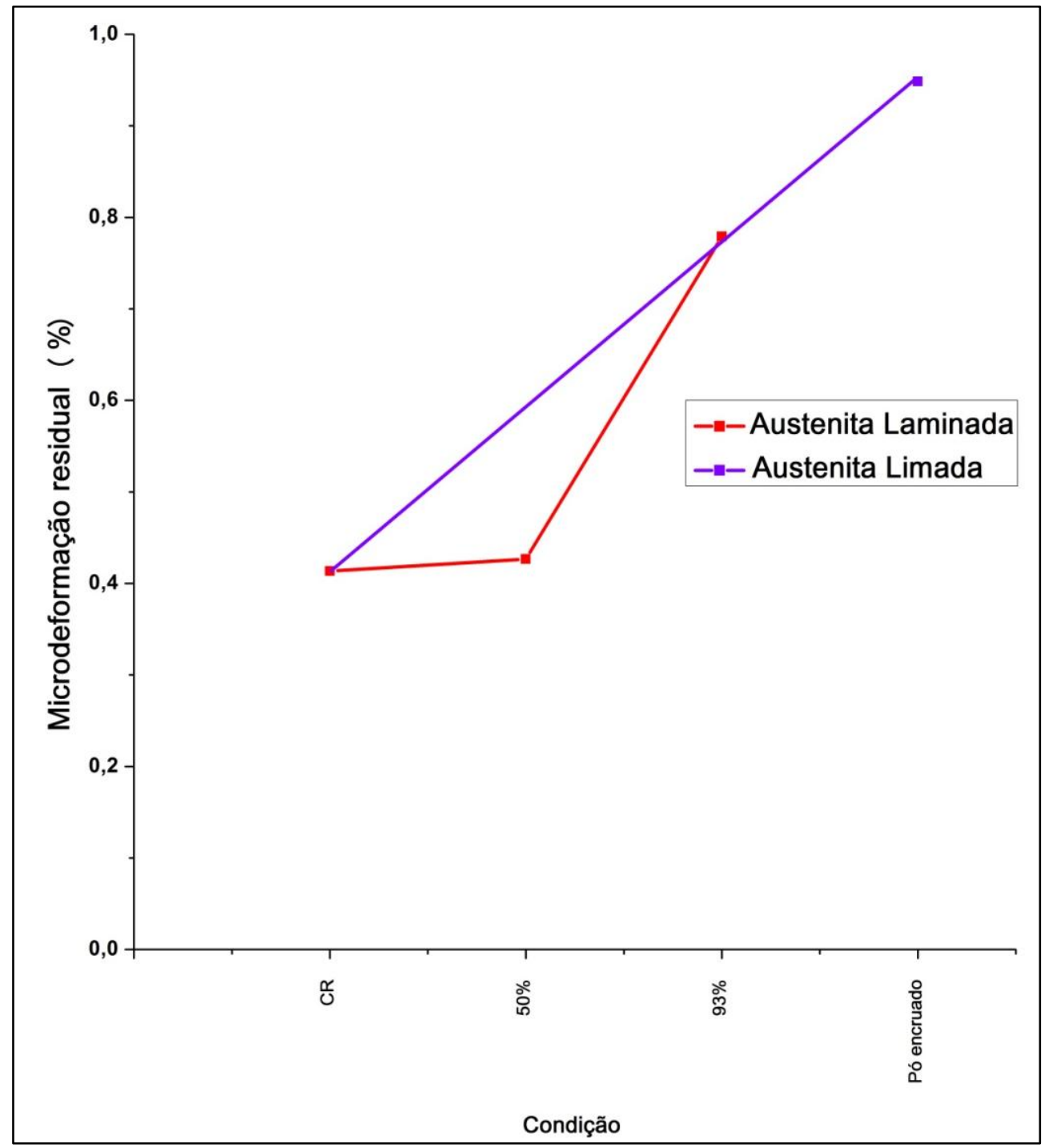

Figura 4.32 - Comparação entre as microdeformações residuais da austenita do aço inoxidável dúplex UNS S31803 deformada por limagem e laminação. 


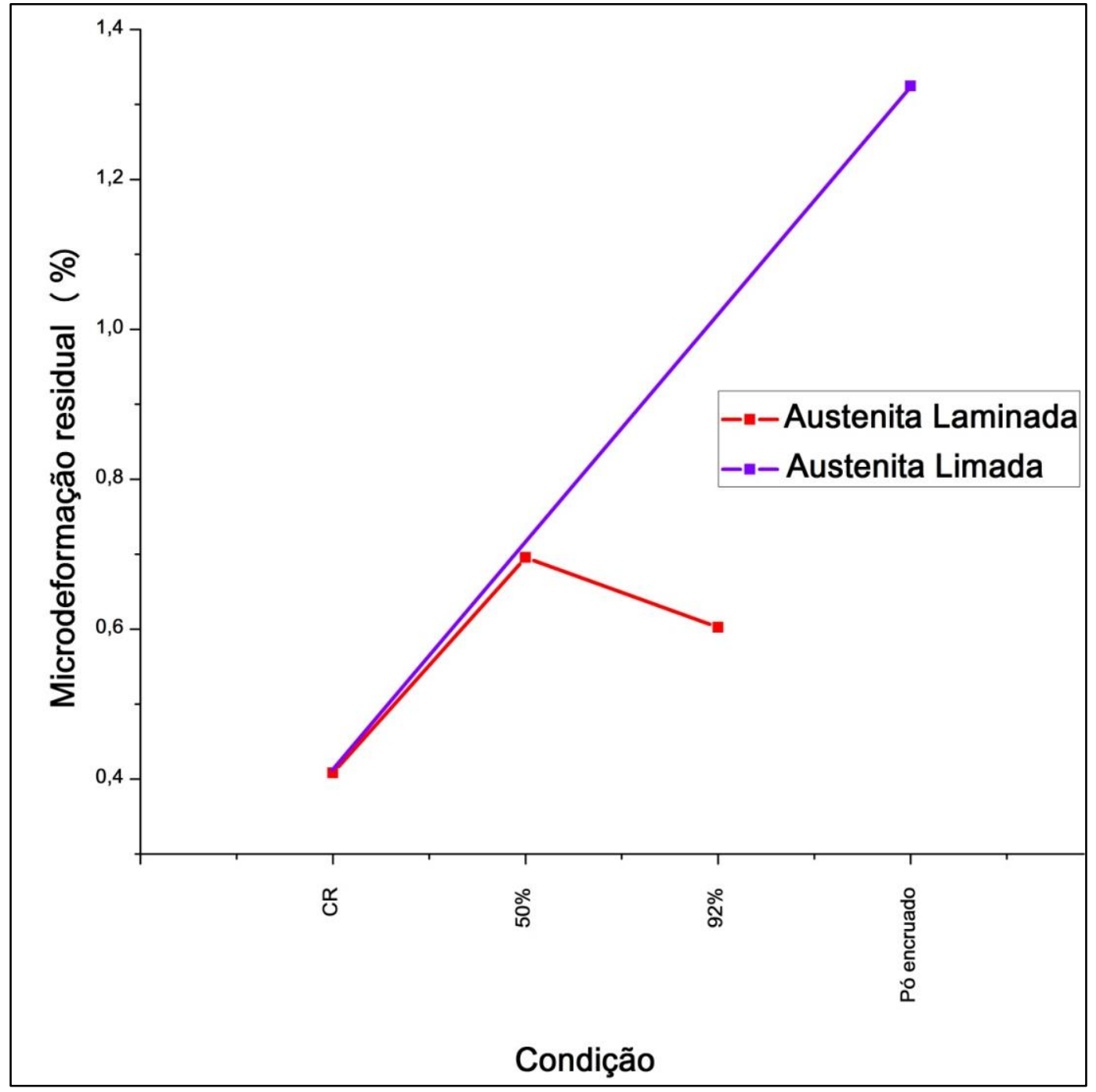

Figura 4.33 - Comparação entre as microdeformações residuais da austenita do aço inoxidável super dúplex UNS S32520 deformada por limagem e laminação. 


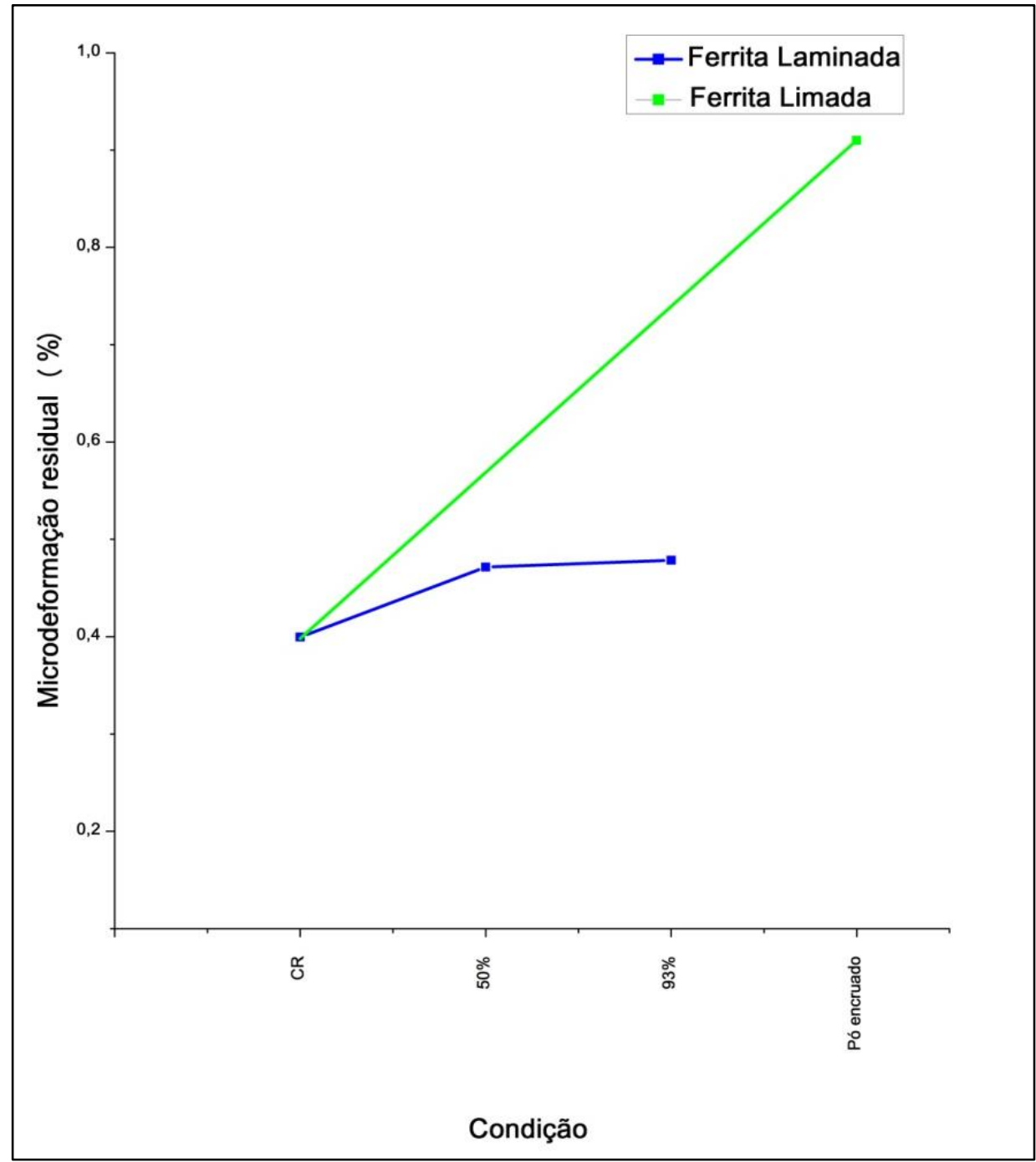

Figura 4.34 - Comparação entre as microdeformações residuais da ferrita do aço inoxidável dúplex UNS S31803 deformada por limagem e laminação. 


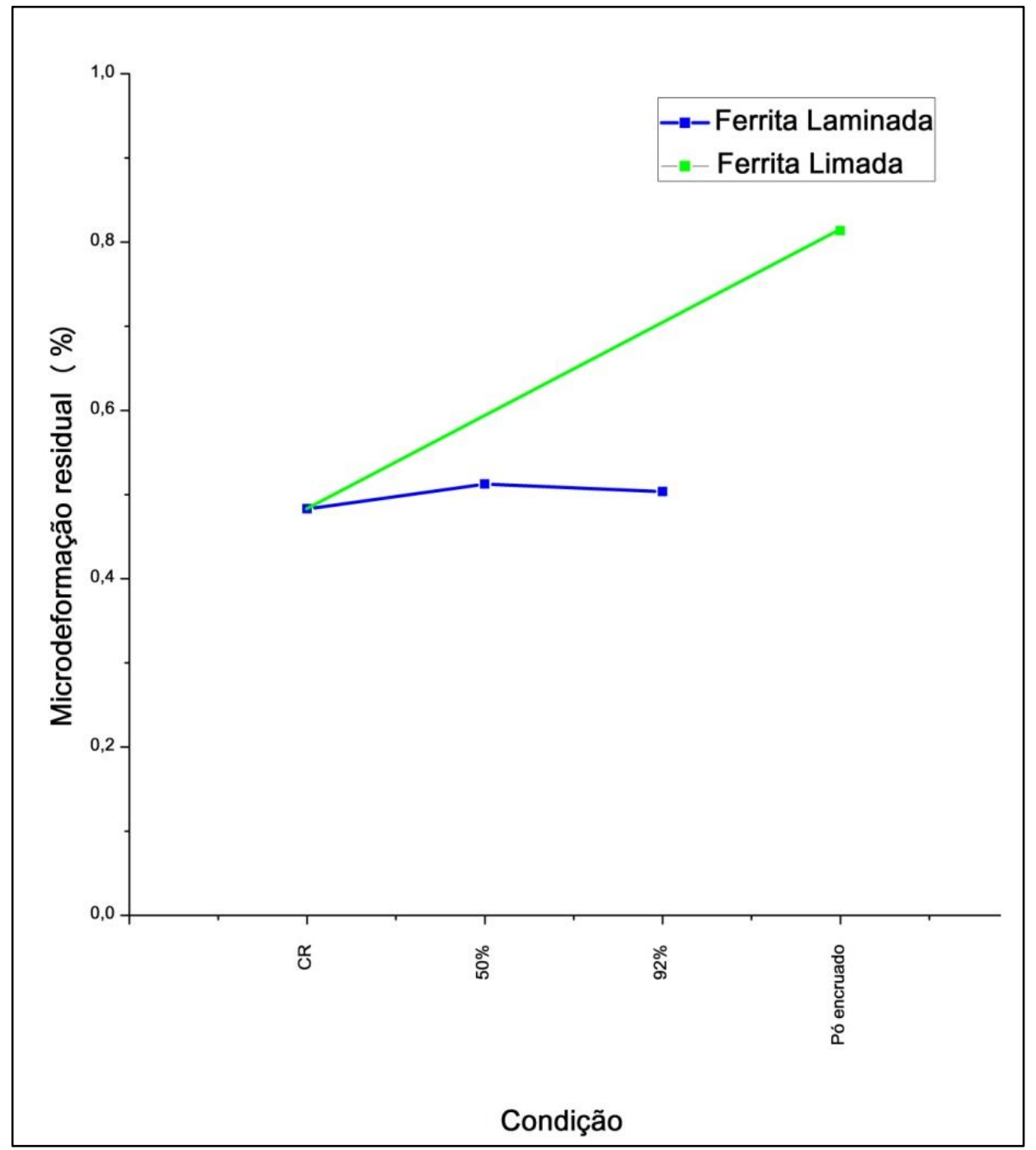

Figura 4.35 - Comparação entre as microdeformações residuais da ferrita do aço inoxidável super dúplex UNS S32520 deformada por limagem e laminação.

Nota-se que, tanto para o aço dúplex UNS S31803 quanto para o super dúplex UNS S32520, os valores de microdeformações residuais para ambas as fases são muito maiores no processo de limagem que no processo de laminação com os parâmetros usados neste trabalho.

\subsection{Determinação dos parâmetros de rede dos aços inoxidáveis dúplex UNS S31803 e super dúplex UNS S32520}

A partir das figuras de difração do cavaco nas condições encruada e tratadas termicamente conforme tabela 3.4, dos cálculos de parâmetros de rede da austenita, efetuou-se o refinamento de tais parâmetros por 2 métodos de 
extrapolação e comparou-se ao parâmetro refinado automaticamente pelo programa computacional GSAS [245]:

$\begin{array}{ll}\checkmark & \text { Método do } \cos ^{2} \theta ; \\ \checkmark & \text { Método do } \cos ^{2} \theta / \operatorname{sen} \theta\end{array}$

Os resultados de tais procedimentos estão listados na tabela $4.7 \mathrm{e}$ tabela 4.8, comparados com os valores de uma fórmula que leva em consideração a presença e porcentagem de elementos químicos, para os aços dúplex e super dúplex, respectivamente.

Tabela 4.7 - Parâmetro de rede da austenita do aço inoxidável dúplex UNS S31803, refinado pelos métodos do $\cos ^{2} \theta$ e $\cos ^{2} \theta / \operatorname{sen} \theta$, comparando-se com o parâmetro refinado pelo programa GSAS, para diversas condições listadas, juntamente com o parâmetro calculado por fórmula [246] que leva em consideração a presença e porcentagem de elementos químicos.

Dúplex UNS S31803

\begin{tabular}{|c|c|c|c|c|}
\hline \multirow{2}{*}{ Condição } & \multicolumn{4}{|c|}{ Método } \\
\hline & $\cos ^{2} \theta$ & $\cos ^{2} \theta / \operatorname{sen} \theta$ & $\begin{array}{c}\text { Programa } \\
\text { GSAS } \\
\text { (Rietveld) }\end{array}$ & $\begin{array}{l}\text { Calculado } \\
\text { (fórmula) }\end{array}$ \\
\hline Encruado & $\begin{array}{c}\mathbf{3 , 6 0 2 4} \\
R^{2}=0,9122\end{array}$ & $\begin{array}{c}\mathbf{3 , 6 0 4 4} \\
R^{2}=0,98495\end{array}$ & $\begin{array}{l}3,610885 \\
\chi^{2}=1,590\end{array}$ & \\
\hline $600^{\circ} \mathrm{C} \_1 \mathrm{~h}$ & $\begin{array}{c}3,6066 \\
R^{2}=0,9397\end{array}$ & $\begin{array}{c}3,6046 \\
R^{2}=0,8334\end{array}$ & $\begin{array}{l}3,609576 \\
\chi^{2}=1,806\end{array}$ & \\
\hline 650_1 h & $\begin{array}{c}3,599 \\
R^{2}=0,9809\end{array}$ & $\begin{array}{c}3,5968 \\
R^{2}=0,9798\end{array}$ & $\begin{array}{l}3,602619 \\
\chi^{2}=1,701\end{array}$ & $\begin{array}{c}3,60640545^{\star} \\
\text { (fórmula de Dyson }\end{array}$ \\
\hline 700_1 h & $\begin{array}{c}3,5975 \\
R^{2}=0,9923\end{array}$ & $\begin{array}{c}3,5935 \\
R^{2}=0,9884\end{array}$ & $\begin{array}{l}3,599034 \\
\chi^{2}=2,962\end{array}$ & \\
\hline 750_1 h & $\begin{array}{c}3,5976 \\
R^{2}=0,9901\end{array}$ & $\begin{array}{c}3,5928 \\
R^{2}=0,9918\end{array}$ & $\begin{array}{l}3,598466 \\
\chi^{2}=2,559\end{array}$ & \\
\hline 1050_1 h & 3,5953 & 3,5962 & 3,602037 & \\
\hline
\end{tabular}




\begin{tabular}{|c|c|c|c|}
\hline & $R^{2}=0,7668$ & $R^{2}=0,8937$ & $\chi^{2}=2,534$ \\
\hline \multirow{2}{*}{$\begin{array}{r}650 \stackrel{\circ}{ }{ }^{\circ} \mathrm{C}-1 \mathrm{~h} \\
+1050 \stackrel{\circ}{\mathrm{C}}-1 \mathrm{~h}\end{array}$} & 3,6011 & 3,599 & 3,604030 \\
\hline & $R^{2}=0,7789$ & $R^{2}=0,8718$ & $\chi^{2}=1,970$ \\
\hline
\end{tabular}

Tabela 4.8 - Parâmetro de rede da austenita do aço inoxidável super dúplex UNS S32520, refinado pelos métodos do $\cos ^{2} \theta$ e $\cos ^{2} \theta / \operatorname{sen} \theta$, comparando-se com o parâmetro refinado pelo programa GSAS para diversas condições listadas, juntamente com o parâmetro calculado por fórmula que leva em consideração a presença e porcentagem de elementos químicos.

\section{Super Dúplex UNS S32520}

\begin{tabular}{|c|c|c|c|c|}
\hline Condição & & & Método & \\
\hline & $\cos ^{2} \theta$ & $\cos ^{2} \theta / \operatorname{sen} \theta$ & $\begin{array}{l}\text { Programa GSAS } \\
\text { (Rietveld) }\end{array}$ & $\begin{array}{l}\text { Calculado } \\
\text { (fórmula) }\end{array}$ \\
\hline Encruado & $\begin{array}{c}3,6259 \\
R^{2}=0,9858\end{array}$ & $\begin{array}{c}3,6192 \\
R^{2}=0,9812\end{array}$ & $\begin{array}{l}3,624109 \\
\chi^{2}=1,284\end{array}$ & \\
\hline $600 \stackrel{\circ}{\mathrm{C} \_} \_1 \mathrm{~h}$ & $\begin{array}{c}3,6171 \\
R^{2}=0,9872\end{array}$ & $\begin{array}{c}3,6110 \\
R^{2}=0,9946\end{array}$ & $\begin{array}{l}3,616462 \\
\chi^{2}=1,615\end{array}$ & \\
\hline $650^{\circ} \mathrm{C} \_1 \mathrm{~h}$ & $\begin{array}{c}3,6058 \\
R^{2}=0,9855\end{array}$ & $\begin{array}{c}3,5995 \\
R^{2}=0,9955\end{array}$ & $\begin{array}{l}3,604894 \\
\chi^{2}=1,735\end{array}$ & \\
\hline $700 \stackrel{\circ}{C} \_1 \mathrm{~h}$ & $\begin{array}{c}3,5935 \\
R^{2}=0,0141\end{array}$ & $\begin{array}{c}3,5935 \\
R^{2}=0,0478\end{array}$ & $\begin{array}{l}3,597956 \\
\chi^{2}=1,745\end{array}$ & $\begin{array}{c}3,60640545^{\star} \\
\text { (fórmula de Dyson } \\
\text { e Holmes) [246] }\end{array}$ \\
\hline $750 \stackrel{\circ}{\mathrm{C}} \_1 \mathrm{~h}$ & $\begin{array}{c}3,5930 \\
R^{2}=0,553\end{array}$ & $\begin{array}{c}3,5939 \\
R^{2}=0,4639\end{array}$ & $\begin{array}{l}3,598615 \\
\chi^{2}=2,559\end{array}$ & \\
\hline $1050 \stackrel{\circ}{0} \_1 \mathrm{~h}$ & $\begin{array}{c}3,6045 \\
R^{2}=0,9284\end{array}$ & $\begin{array}{c}3, \mathbf{6 0 2 2} \\
R^{2}=0,9923\end{array}$ & $\begin{array}{l}3,606431 \\
\chi^{2}=1,784\end{array}$ & \\
\hline $\begin{array}{r}650 \stackrel{\circ}{ }{ }^{\circ} \mathrm{C}-1 \mathrm{~h} \\
+1050 \stackrel{\circ}{\mathrm{C}} \_1 \mathrm{~h}\end{array}$ & $\begin{array}{c}3,6012 \\
R^{2}=0,9759\end{array}$ & $\begin{array}{c}3,6042 \\
R^{2}=0,9864\end{array}$ & $\begin{array}{l}3,608446 \\
\chi^{2}=2,077\end{array}$ & \\
\hline
\end{tabular}

Nota-se, pelo refinamento dos parâmetros, que os métodos apresentam razoável concordância para ambos os aços no que se refere ao parâmetro de rede 
da austenita. Tal parâmetro diminui com o tratamento térmico de 1 hora, sendo que diminui mais para temperaturas maiores. Nas temperaturas onde há presença de fase sigma, os coeficientes de correlação indicam diminuição na precisão dos métodos. Nos tratamentos onde a temperatura promove ampla recristalização (1050 ${ }^{\circ} \mathrm{C}$, seja em estágio único ou passando por reversão a $650 \stackrel{\circ}{\circ} \mathrm{C}$ ), o parâmetro de rede volta a crescer e a concordância dos métodos é bem razoável quando comparado com a fórmula do parâmetro de rede da austenita, a qual leva em consideração a presença de vários elementos químicos.

A austenita do aço inoxidável super dúplex, possui parâmetro de rede ligeiramente maior que 0 do dúplex. A presença de uma maior quantidade de elementos de liga no super dúplex, especialmente nitrogênio, está relacionado à esta característica.

A mesma metodologia de extrapolação foi utilizada para o cálculo do parâmetro de rede da ferrita do aço inoxidável dúplex, conforme tabela 4.9 e do aço inoxidável super dúplex, tabela 4.10 conforme. Em ambos os casos, fizeram-se comparações com os parâmetros refinados pelo programa GSAS.

Tabela 4.9 - Parâmetro de rede da ferrita do aço inoxidável dúplex UNS S31803, refinado pelos métodos do $\cos ^{2} \theta$ e $\cos ^{2} \theta / \operatorname{sen} \theta$, comparando-se com os parâmetros refinados pelo programa GSAS, para diversas condições listadas.

Dúplex UNS S31803

\begin{tabular}{cc|c|c|}
\multicolumn{1}{c|}{ Condição } & \multicolumn{3}{c}{ Método } \\
\cline { 2 - 4 } Encruado & $\cos ^{2} \theta$ & $\cos ^{2} \theta / \operatorname{sen} \theta$ & $\begin{array}{c}\text { Programa GSAS } \\
\text { (Rietveld) }\end{array}$ \\
\cline { 2 - 4 } & $\mathbf{2 , 8 7 6 9}$ & $\mathbf{2 , 8 7 8}$ & $\mathbf{2 , 8 8 2 0 2 5}$ \\
$\mathrm{R}^{2}=0,6146$ & $\mathrm{R}^{2}=0,98495$ & $\chi^{2}=1,590$ \\
\hline 600 ㅇ﹎1 h & $\mathbf{2 , 8 7 5 3}$ & $\mathbf{2 , 8 7 7 3}$ & $\mathbf{2 , 8 7 8 5 2 2}$ \\
& $\mathrm{R}^{2}=0,9259$ & $\mathrm{R}^{2}=0,7481$ & $\chi^{2}=1,806$ \\
\hline 650 ㅇ﹎1 h & $\mathbf{2 , 8 7 6 6}$ & $\mathbf{2 , 8 7 4 7}$ & $\mathbf{2 , 8 7 8 7 7 6}$ \\
& $\mathrm{R}^{2}=0,9977$ & $\mathrm{R}^{2}=0,9133$ & $\chi^{2}=1,701$ \\
\hline \multirow{2}{*}{700 ㅇ﹎1 h } & $\mathbf{2 , 8 7 3 3}$ & $\mathbf{2 , 8 7 1 3}$ & $\mathbf{2 , 8 7 4 1 0 7}$ \\
& $\mathrm{R}^{2}=0,8925$ & $\mathrm{R}^{2}=0,9903$ & $\chi^{2}=2,962$ \\
\hline
\end{tabular}




\begin{tabular}{|c|c|c|c|}
\hline $750 \stackrel{\circ}{0} \_1 \mathrm{~h}$ & $\begin{array}{c}\mathbf{2 , 8 7 5 9} \\
\mathrm{R}^{2}=0,9307\end{array}$ & $\begin{array}{c}\mathbf{2 , 8 7 3 2} \\
R^{2}=0,9932\end{array}$ & $\begin{array}{r}2,876396 \\
\chi^{2}=3,309\end{array}$ \\
\hline $1050 \stackrel{\circ}{\circ} \_1 \mathrm{~h}$ & $\begin{array}{c}2,8772 \\
R^{2}=0,8221\end{array}$ & $\begin{array}{c}2,8777 \\
R^{2}=0,6477\end{array}$ & $\begin{array}{l}2,881635 \\
\chi^{2}=2,534\end{array}$ \\
\hline $\begin{aligned} & 650 \stackrel{\circ}{\circ} \mathrm{C}-1 \mathrm{~h} \\
+ & 1050 \stackrel{\circ}{\mathrm{C}} \_1 \mathrm{~h}\end{aligned}$ & $\begin{array}{c}2,8783 \\
R^{2}=0,8124\end{array}$ & $\begin{array}{c}2,8771 \\
R^{2}=0,9581\end{array}$ & $\begin{array}{l}2,880997 \\
\chi^{2}=1,970\end{array}$ \\
\hline
\end{tabular}

Tabela 4.10 - Parâmetro de rede da ferrita do aço inoxidável dúplex UNS S32520, refinado pelos métodos do $\cos ^{2} \theta$ e $\cos ^{2} \theta$ /sen $\theta$, comparando-se com os parâmetros refinados pelo programa GSAS, para diversas condições listadas.

Super Dúplex UNS S32520

Condição

Método

\begin{tabular}{|c|c|c|c|}
\hline & $\cos ^{2} \theta$ & $\cos ^{2} \theta / \operatorname{sen} \theta$ & $\begin{array}{l}\text { Programa GSAS } \\
\text { (Rietveld) }\end{array}$ \\
\hline Encruado & $\begin{array}{c}\mathbf{2 , 8 8 2 2} \\
R^{2}=0,9072\end{array}$ & $\begin{array}{c}\mathbf{2 , 8 8 0 1} \\
\mathrm{R}^{2}=0,7259\end{array}$ & $\begin{array}{l}\mathbf{2 , 8 8 3 7 2 7} \\
\chi^{2}=1,284\end{array}$ \\
\hline $600 \stackrel{\circ}{\mathrm{C}} \_1 \mathrm{~h}$ & $\begin{array}{c}2,8792 \\
R^{2}=0,9917\end{array}$ & $\begin{array}{c}2,8751 \\
R^{2}=0,9742\end{array}$ & $\begin{array}{l}\mathbf{2 , 8 7 9 1 2 8} \\
\chi^{2}=1,615\end{array}$ \\
\hline $650^{\circ} \mathrm{C} \_1 \mathrm{~h}$ & $\begin{array}{c}2,8799 \\
R^{2}=0,9336\end{array}$ & $\begin{array}{c}2,8753 \\
R^{2}=0,9982\end{array}$ & $\begin{array}{l}\mathbf{2 , 8 7 8 4 6 6} \\
\chi^{2}=1,735\end{array}$ \\
\hline $700 \stackrel{\circ}{C} \_1 \mathrm{~h}$ & $\begin{array}{c}2,8686 \\
R^{2}=0,1505\end{array}$ & $\begin{array}{c}2,8679 \\
R^{2}=0,0214\end{array}$ & $\begin{array}{l}2,871732 \\
\chi^{2}=1,745\end{array}$ \\
\hline $750 \stackrel{\circ}{C} \_1 \mathrm{~h}$ & $\mathbf{x}$ & $x$ & $\begin{array}{l}2,863698 \\
\chi^{2}=2,559\end{array}$ \\
\hline $1050^{\circ} \mathrm{C} \_1 \mathrm{~h}$ & $\begin{array}{c}2,8789 \\
R^{2}=0,7045\end{array}$ & $\begin{array}{c}2,8779 \\
R^{2}=0,8874\end{array}$ & $\begin{array}{l}2,881291 \\
\chi^{2}=1,784\end{array}$ \\
\hline $\begin{aligned} & 650^{\circ} \mathrm{C}-1 \mathrm{~h} \\
&+1050^{\circ} \mathrm{C}-1 \mathrm{~h}\end{aligned}$ & 2,8744 & 2,8773 & 2,880700 \\
\hline
\end{tabular}




$$
\begin{array}{l|l|l}
\mathrm{R}^{2}=0,9767 & \mathrm{R}^{2}=0,9837 & \chi^{2}=2,077
\end{array}
$$

Nota-se que os parâmetros refinados pelos métodos de extrapolação apresentam boa concordância entre si e também comparando-se com os parâmetros refinados pelo programa GSAS. Ainda, é possível observar que os coeficientes de correlação pelos métodos de extrapolação a $700{ }^{\circ} \mathrm{C}$ estavam muito baixos (muita imprecisão) e não foi possível calcular o parâmetro de rede da ferrita a $750 \stackrel{\circ}{\circ}$ no super dúplex. Isto está relacionado à baixa fração volumétrica de ferrita devida a decomposição eutetóide desta fase em fase sigma e austenita secundária.

\subsection{Histereses magnéticas a partir do ensaio de magnetização}

A figura 4.36 apresenta histereses magnéticas do aço inoxidável dúplex UNS S31803 nas condições como recebido (CR), laminado a 50 e $93 \%$.

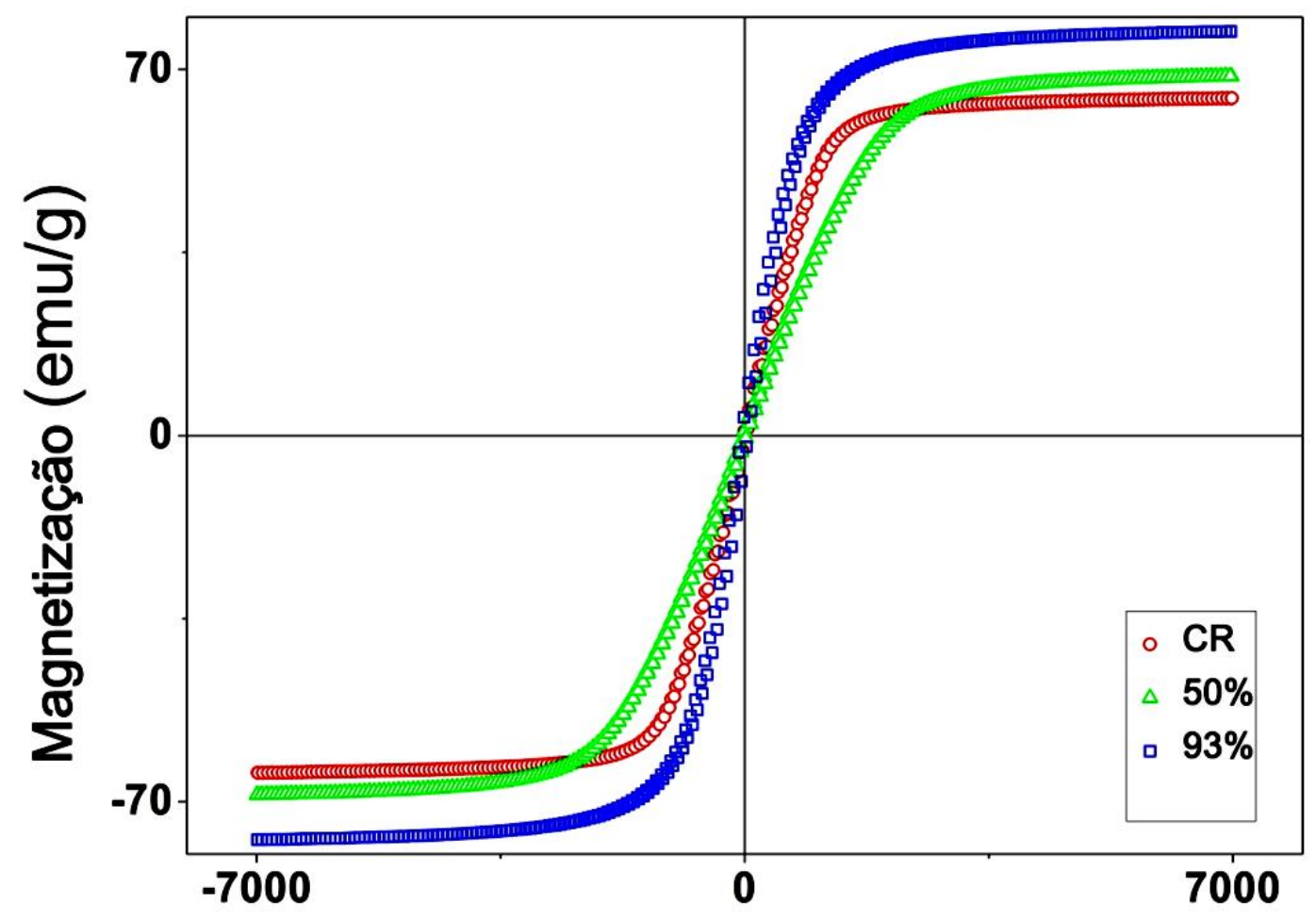

\section{Campo Magnético Aplicado (G)}

Figura 4.36 - Curvas de histerese magnética do aço inoxidável dúplex UNS S31803 nas condições como recebido (CR), laminado a $50 \%$ e $93 \%$, conforme legenda de cores. 
Uma primeira observação que pode ser feita é que na medida em que se aumenta o grau de laminação, aumenta-se o valor de saturação magnética do material. Como a saturação magnética está intimamente ligada à fração volumétrica de fase magnética, esse fato torna-se uma importante evidência no estudo de transformação martensítica induzida por deformação que ocorre na austenita. A transformação é maior, quanto maior o grau de laminação, comparando-se essas três condições da amostra.

A figura 4.37 a representa graficamente a histerese magnética de 3 amostras deformadas $50 \%$ por laminação a frio, 2 delas, posteriormente tratadas termicamente por 1 hora em 2 temperaturas diferentes, $600{ }^{\circ} \mathrm{C}$ e $650 \stackrel{\circ}{\circ} \mathrm{C}$, comparando-se com a amostra como recebida. A figura 4.37 b é uma expansão do $1^{\circ}$ quadrante da histerese, com a finalidade de mostrar detalhadamente a saturação magnética dos casos descritos.

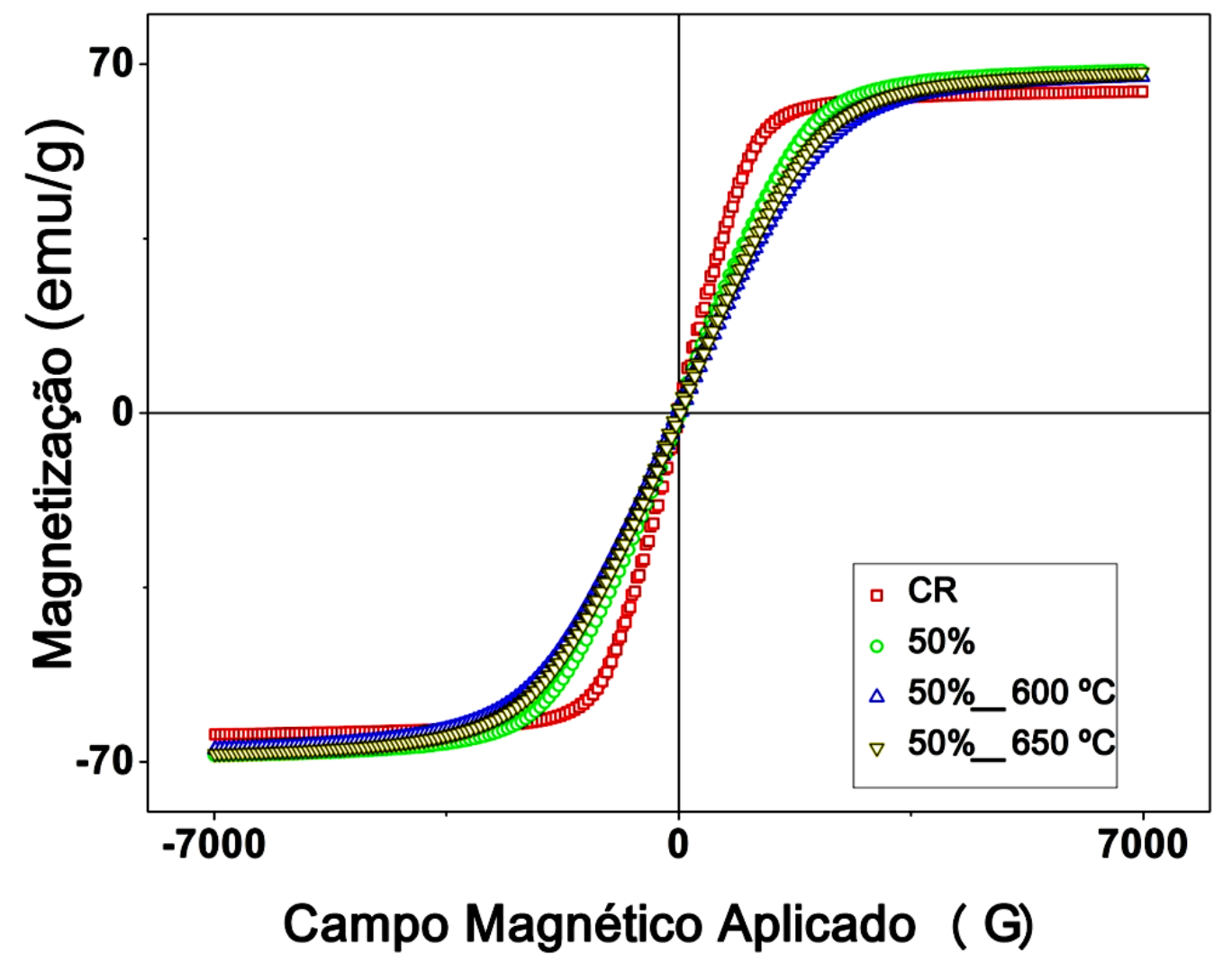

Figura 4.37 a - Curvas de histerese magnética do aço inoxidável dúplex UNS S31803 nas condições como recebido (CR), laminado a $50 \%$ sem tratamento térmico, laminado a $50 \%$ e tratado a $600{ }^{\circ} \mathrm{C}$ por 1 hora, laminado a $50 \%$ e tratado a $650 \stackrel{\circ}{\circ}$ por 1 hora, conforme legenda de cores. 


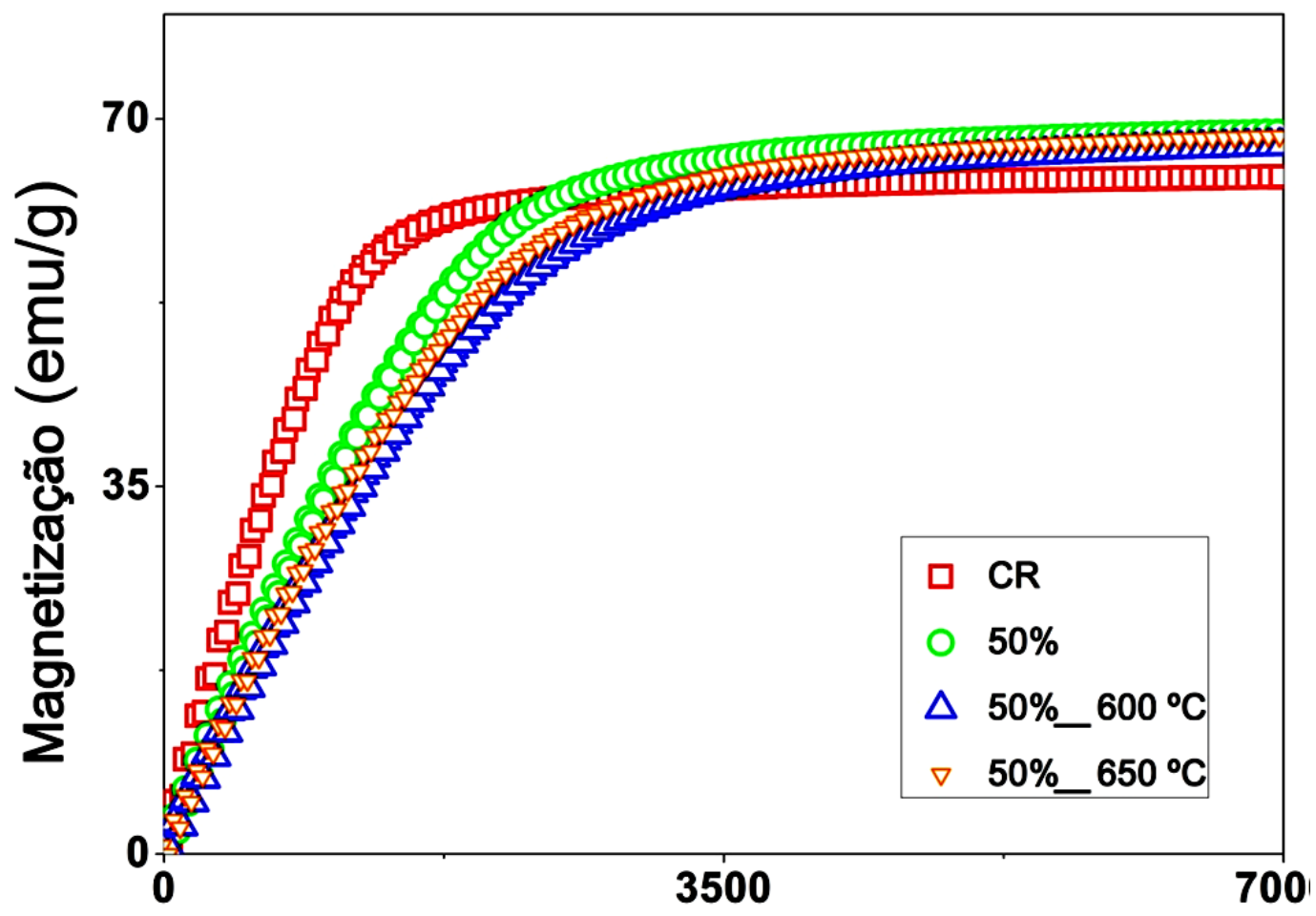

\section{Campo Magnético Aplicado (G)}

Figura $4.37 \mathrm{~b}$ - Detalhamento da saturação magnética a partir das curvas de histerese magnética do aço inoxidável dúplex UNS S31803 nas condições como recebido (CR), laminado a $50 \%$ sem tratamento térmico, laminado a $50 \%$ e tratado a $600{ }^{\circ} \mathrm{C}$ por 1 hora, laminado a $50 \%$ e tratado a 650 ${ }^{\circ} \mathrm{C}$ por 1 hora, conforme legenda de cores.

Como já havia sido observada anteriormente, a laminação de 50 \% causou um leve aumento na saturação magnética, por transformação martensítica na austenita. Os tratamentos térmicos realizados trouxeram poucas mudanças significativas no comportamento de reversão da martensita induzida por deformação. Esse fator pode estar relacionado à pouca fração volumétrica obtida para esse grau de laminação.

A figura 4.38 a representa graficamente a histerese magnética de 3 amostras deformadas $93 \%$ por laminação a frio, 2 delas, posteriormente tratadas termicamente por 1 hora em 2 temperaturas diferentes, $600{ }^{\circ} \mathrm{C}$ e $650^{\circ} \mathrm{C}$, comparando-se com a amostra como recebida. A figura 4.38 b é uma expansão do $1^{\circ}$ quadrante da histerese, com a finalidade de mostrar detalhadamente a saturação magnética em todos os casos descritos. 


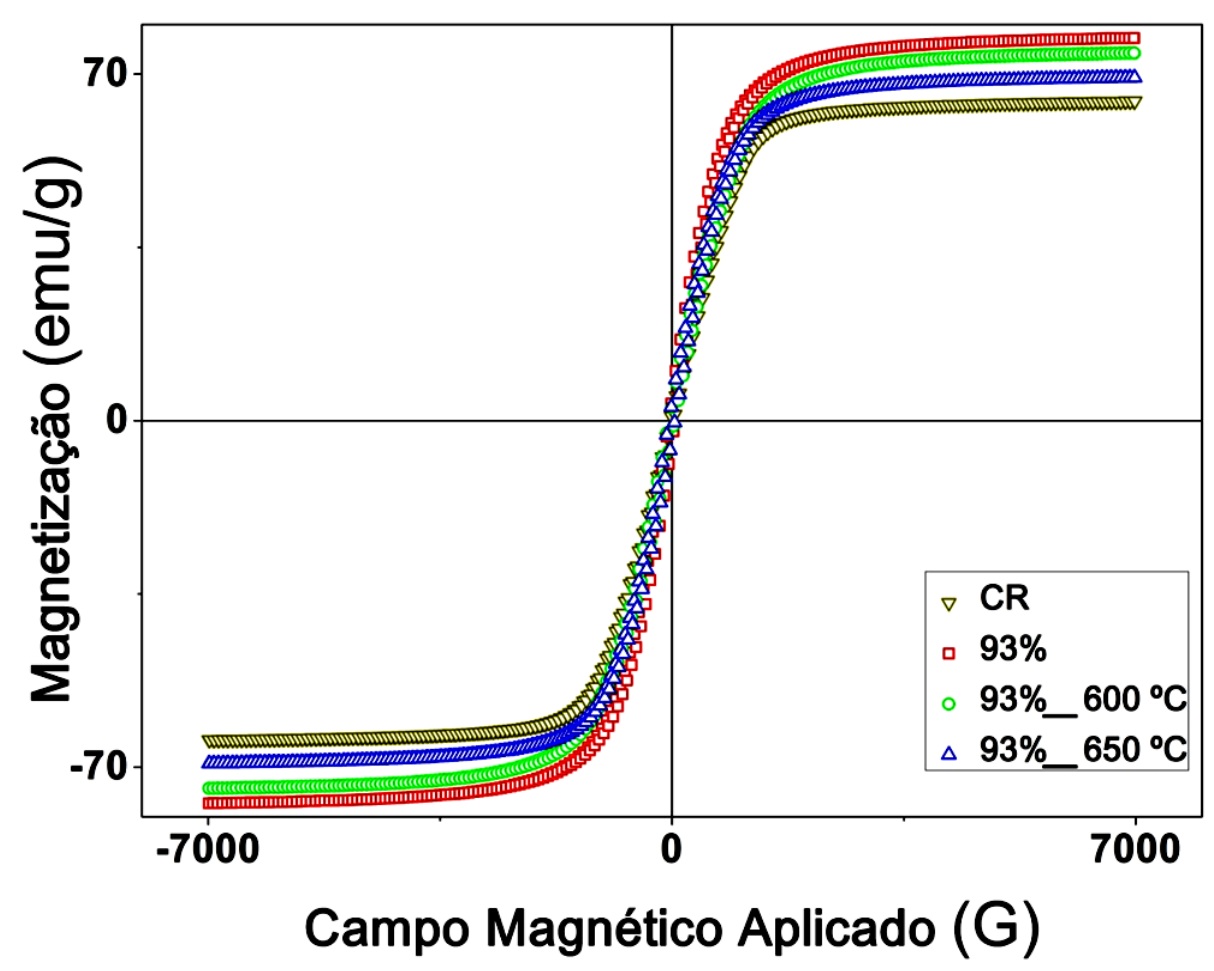

Figura 4.38 a - Curvas de histerese magnética do aço inoxidável dúplex UNS S31803 nas condições como recebido (CR), laminado a $93 \%$ sem tratamento térmico, laminado a $93 \%$ e tratado a $600 \stackrel{\circ}{\circ}$ por 1 hora, laminado a $93 \%$ e tratado a $650{ }^{\circ} \mathrm{C}$ por 1 hora, conforme legenda de cores.

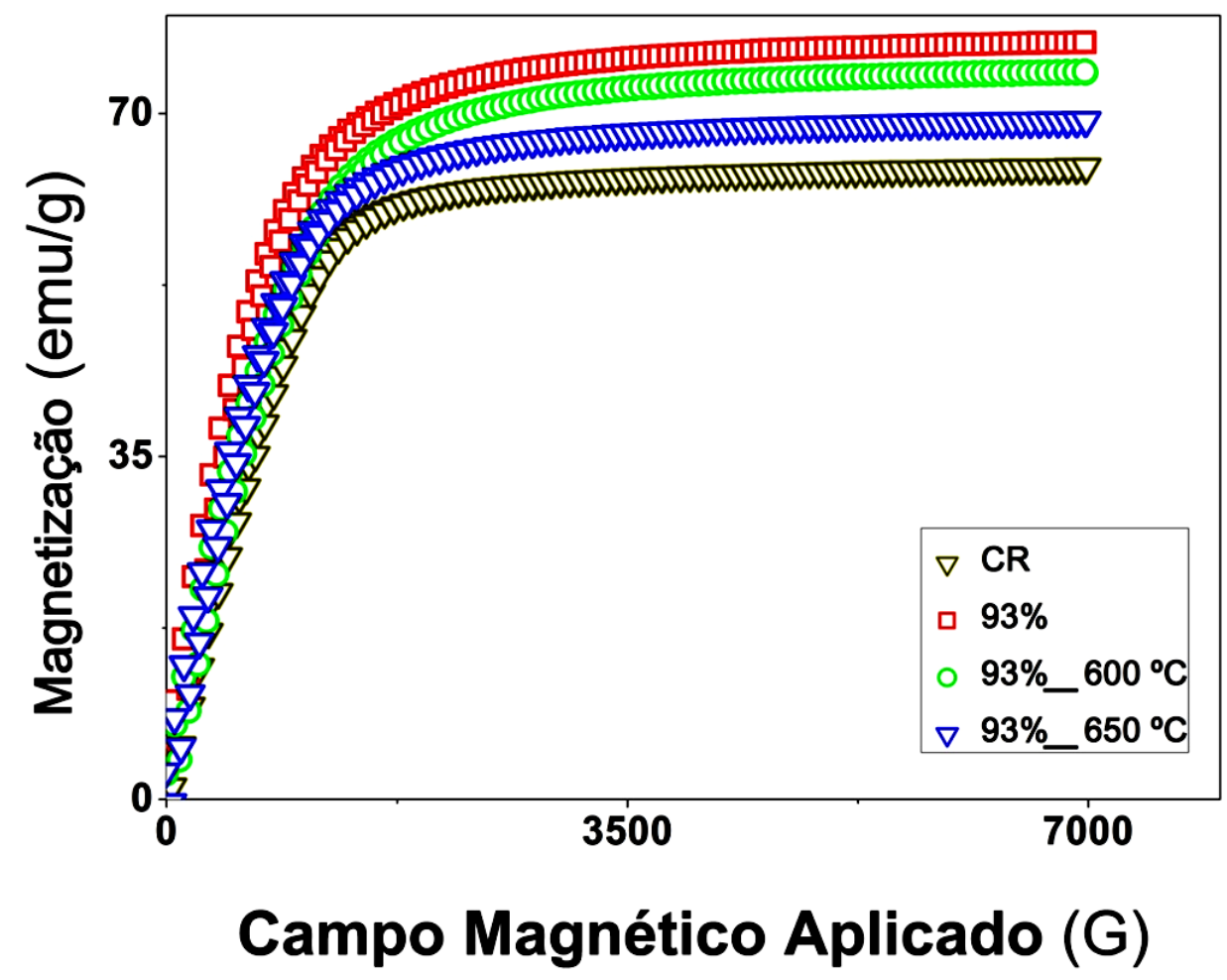

Figura $4.38 \mathrm{~b}$ - Detalhamento da saturação magnética a partir da curvas de histerese magnética do aço inoxidável dúplex UNS S31803 nas condições como recebido (CR), laminado a $93 \%$ sem tratamento térmico, laminado a $93 \%$ e tratado a $600 \stackrel{\circ}{\circ}$ por 1 hora, laminado a $93 \%$ e tratado a 650 oC por 1 hora, conforme legenda de cores. 
Com o auxílio dessas figuras, nota-se que para $93 \%$ de laminação há um aumento significativo na saturação magnética devido à transformação martensítica. Essa martensita induzida por deformação é revertida em austenita durante tratamentos térmicos de $600{ }^{\circ} \mathrm{C}$ e $650^{\circ} \mathrm{C}$ por 1 hora, fato evidenciado pela diminuição da saturação magnética (curvas de cor verde e preta) em relação à amostra deformada (curva azul). A reversão é maior para a temperatura de $650 \stackrel{\circ}{\circ}$. Entretanto, essa reversão é parcial, pois os valores de saturação magnética são maiores que a da amostra como recebida.

Comparativamente às situações descritas acima, a figura 4.39 apresenta histereses magnéticas do aço inoxidável super dúplex UNS S32520 nas condições como recebido (CR), laminado a 50 e $92 \%$.

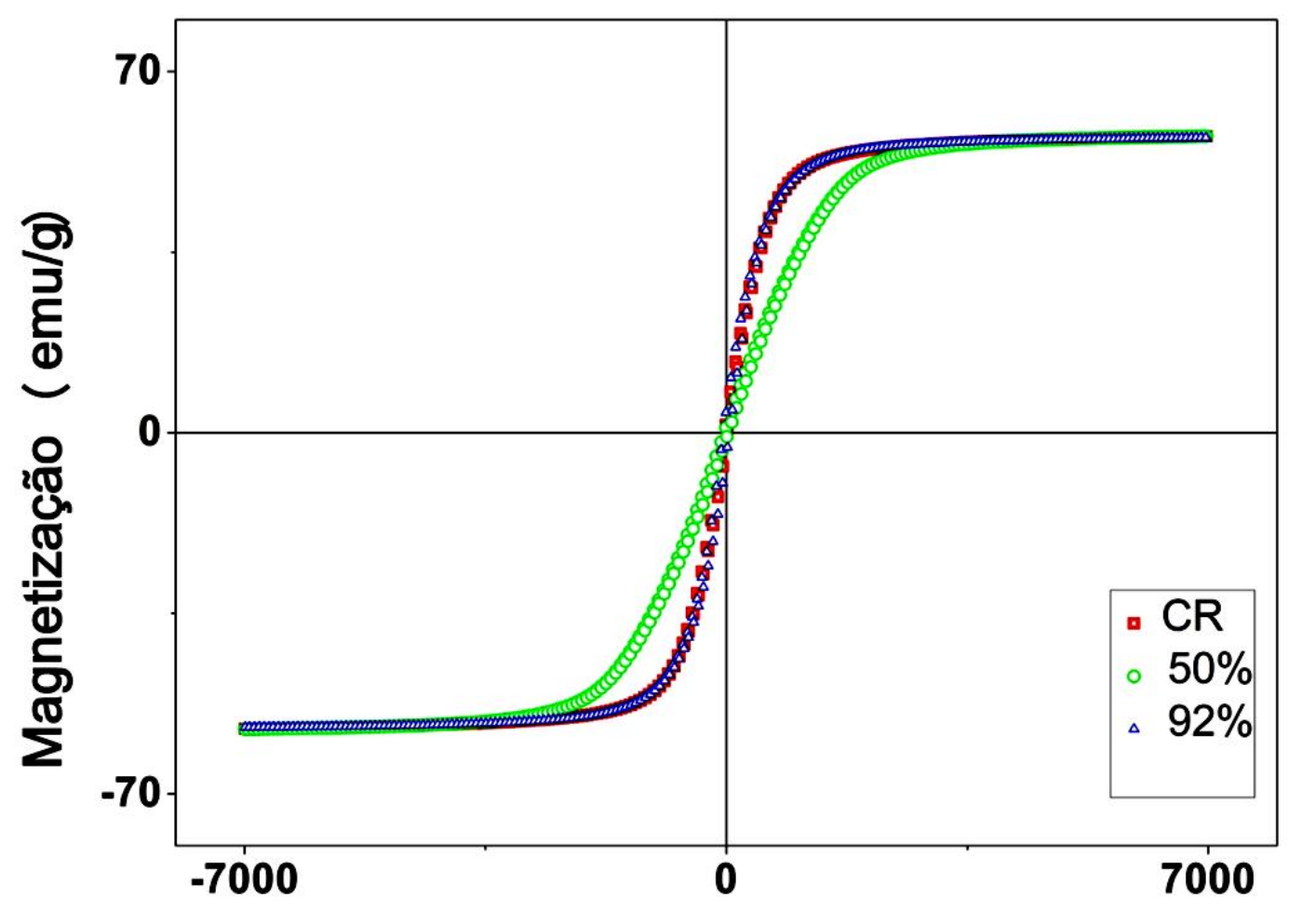

\section{Campo Magnético aplicado (G)}

Figura 4.39 - Curvas de histerese magnética do aço inoxidável super dúplex UNS S32520 nas condições como recebido (CR), laminado a 50 e $92 \%$, conforme legenda de cores.

Observa-se nessa representação, a sobreposição das curvas de histerese da condição como recebido e deformado por laminação 50 e $92 \%$. Esse fato é uma importante evidência da resistência do aço inoxidável super dúplex à transformação martensítica, mesmo para altos graus de deformação. A austenita do aço inoxidável super dúplex tem um maior teor de elemento intersticial (nitrogênio), o que a torna 
mais estável e menos susceptível à transformação martensítica para essa modalidade de deformação. Como não há evidências de transformação de fase induzida por deformação nesse aço, é de se esperar que os tratamentos térmicos tanto de $600 \stackrel{\circ}{\circ}$ quanto de $650 \stackrel{\circ}{\circ}$ por 1 hora, não acarretem em mudanças significativas na saturação magnética em relação ao material como recebido. Nas figuras podem ser observados os efeitos desses tratamentos em amostras deformadas por 50 e $92 \%$ de laminações comparadas com a amostra inicial (como recebida).

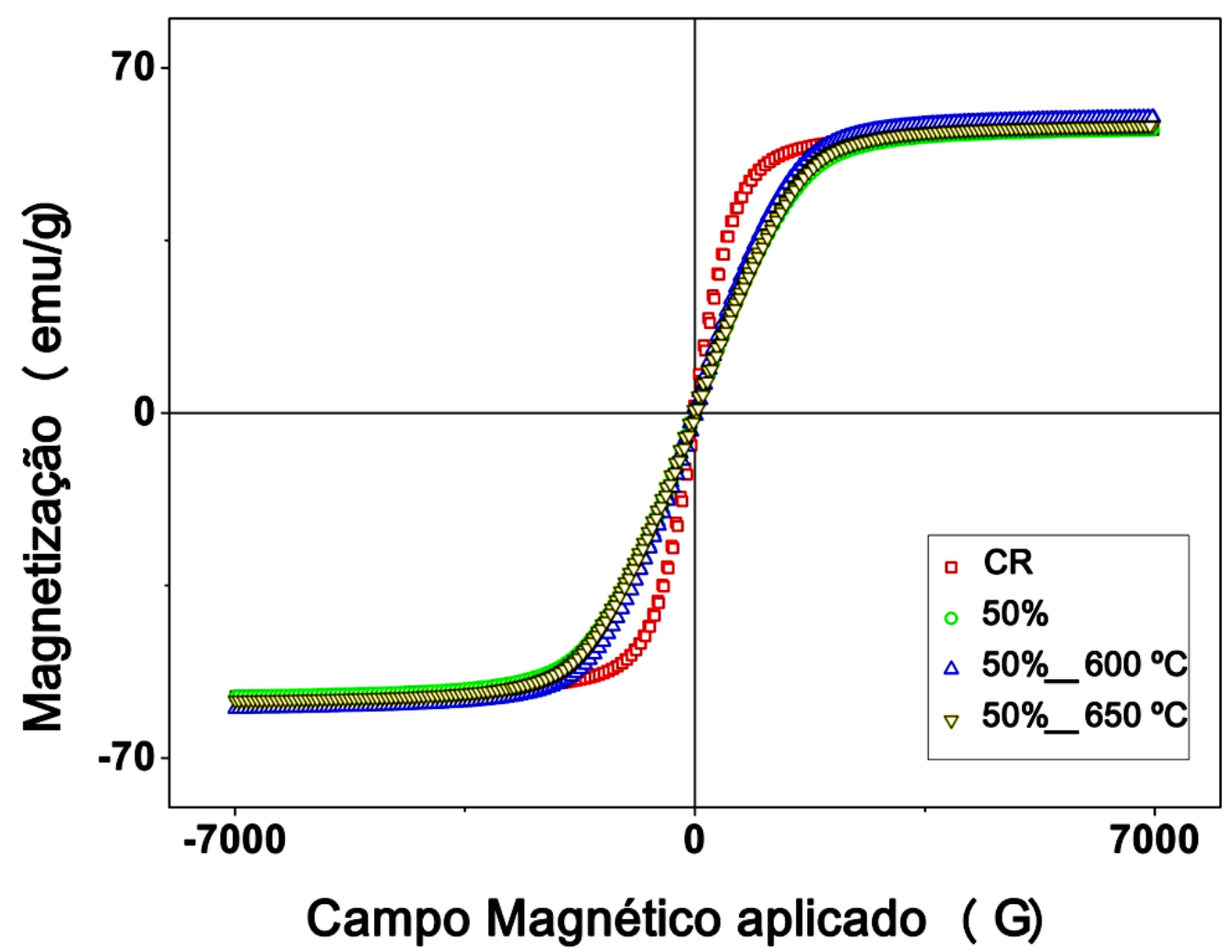

Figura 4.40 - Curvas de histerese magnética do aço inoxidável super dúplex UNS $\$ 32520$ nas condições como recebido (CR), laminado a $50 \%$ sem tratamento térmico, laminado a $50 \%$ e tratado a $600 \stackrel{\circ}{\circ}$ por 1 hora, laminado a $50 \%$ e tratado a $650 \stackrel{\circ}{\circ}$ por 1 hora, conforme legenda de cores. 


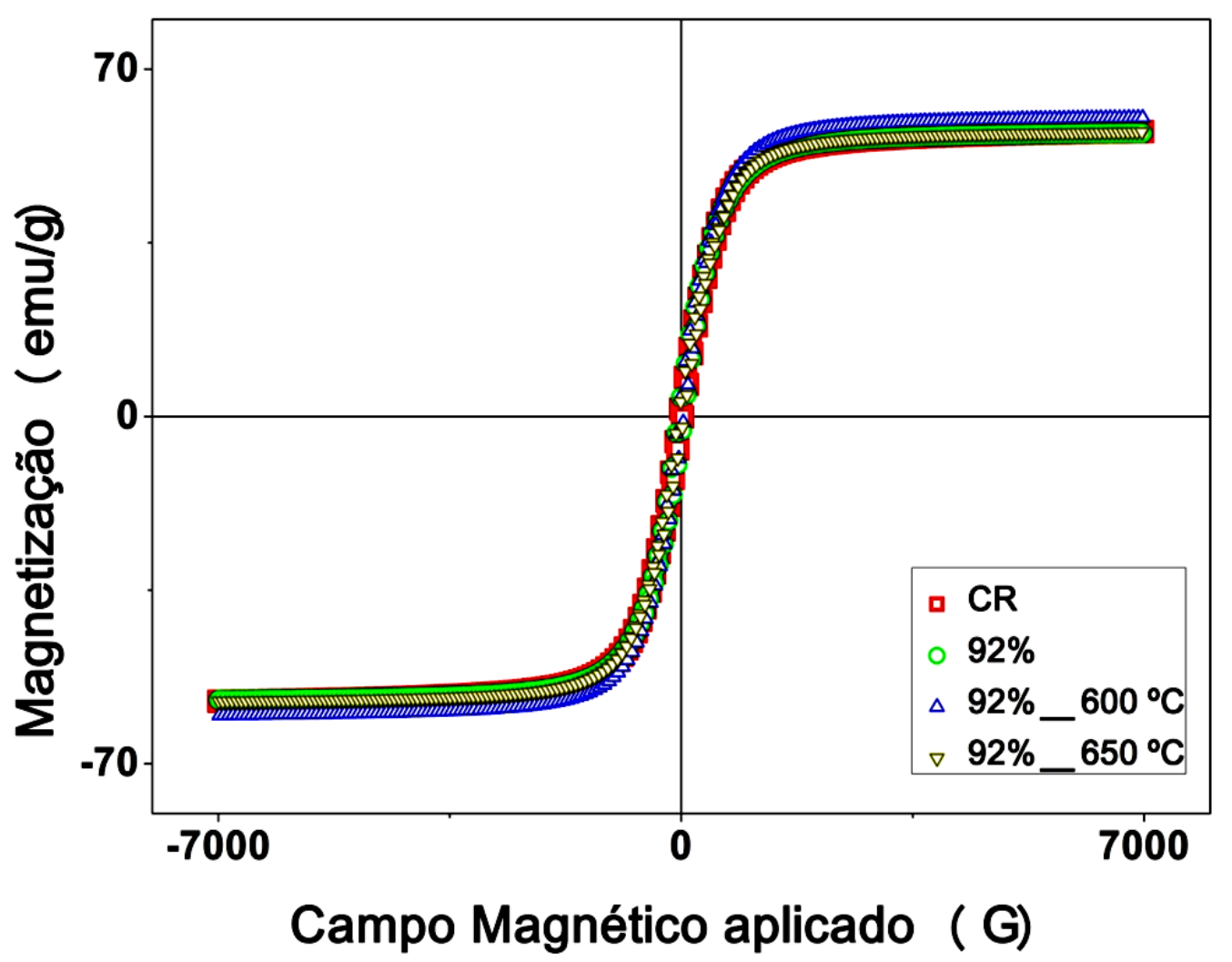

Figura 4.41 - Curvas de histerese magnética do aço inoxidável super dúplex UNS S32520 nas condições como recebido (CR), laminado a $92 \%$ sem tratamento térmico, laminado a $92 \%$ e tratado a $600^{\circ} \mathrm{C}$ por 1 hora, laminado a $92 \%$ e tratado a $650 \stackrel{\circ}{\circ}$ por 1 hora, conforme legenda de cores.

De fato não ocorrem as mudanças mencionadas, fortalecendo a hipótese de que não houve reversão porque as condições de laminação não foram suficientes para a transformação de martensita induzida por deformação na austenita para o caso do aço inoxidável super dúplex.

Resumidamente, os resultados de saturação magnética, coercividade $(\mathrm{Hc})$ e remanência $(\mathrm{Mr})$, com suas respectivas unidades, obtidos com o auxílio das histereses magnéticas, podem ser observados nas tabelas 4.9 e 4.10 .

Tabela 4.11 - Tabela de resumo dos resultados de saturação magnética, coercividade $(\mathrm{Hc})$ e remanência (Mr), bem como a massa utilizada no ensaio, para o aço inoxidável dúplex UNS S31803.

DÚPLEX

\begin{tabular}{ccccc} 
Amostra & $\begin{array}{c}\text { Saturação } \\
\text { emu/g }\end{array}$ & $\begin{array}{c}\mathrm{Hc} \\
\mathrm{G}\end{array}$ & $\begin{array}{c}\mathrm{Mr} \\
\mathrm{emu} / \mathrm{g}\end{array}$ & $\begin{array}{c}\text { Massa utilizada } \\
\mathrm{g}\end{array}$ \\
\hline CR & 64,46 & 20,549 & 1,203 & 0,07245 \\
$50 \%$ & 68,71 & 28,884 & 1,107 & 0,3335 \\
$93 \%$ & 77,29 & 46,018 & 4,413 & 0,0586 \\
$50 \_600$ & 67,48 & 31,664 & 1,03 & 0,32355
\end{tabular}




$\begin{array}{lllll}93 \_600 & 74,27 & 41,753 & 3,03 & 0,0457 \\ 50 \_650 & 68,38 & 32,219 & 1,123 & 0,35645 \\ 93 \_650 & 69,26 & 43,332 & 3,489 & 0,0693\end{array}$

Tabela 4.12 - Tabela de resumo dos resultados de saturação magnética, coercividade (Hc) e remanência (Mr), bem como a massa utilizada no ensaio, para o aço inoxidável super dúplex UNS S32520.

SUPER DÚPLEX

\begin{tabular}{ccccc} 
Amostra & $\begin{array}{c}\text { Saturação } \\
\text { emu/g }\end{array}$ & $\begin{array}{c}\mathrm{Hc} \\
\mathrm{G}\end{array}$ & $\begin{array}{c}\mathrm{Mr} \\
\mathrm{emu} / \mathrm{g}\end{array}$ & $\begin{array}{c}\text { Massa utilizada } \\
\mathrm{g}\end{array}$ \\
\hline CR & 57,4 & 21,248 & 1,974 & 0,088 \\
$50 \%$ & 57,45 & 29,584 & 1,187 & 0,3173 \\
$92 \%$ & 57,15 & 43,822 & 4,462 & 0,1014 \\
$50 \_600$ & 59,99 & 29,374 & 1,33 & 0,2501 \\
$92 \_600$ & 60,22 & 42,429 & 4,522 & 0,10345 \\
$50 \_650$ & 58,26 & 29,472 & 1,16 & 0,2712 \\
$92 \_650$ & 57,37 & 41,021 & 3,735 & 0,0907 \\
\hline
\end{tabular}

Todavia, como houve dificuldade para usinar discos das amostras laminadas (espessura muito fina para fixar a lâmina no torno), e as análises foram feitas em amostras quadradas, o efeito da orientação dos grãos pode ter alterado o "caminho" ou trajetória das curvas de histerese. Por isso, a comparação e estudos dos efeitos da deformação e tratamentos térmicos na coercividade e remanência devem ser analisados de uma forma mais criteriosa e específica para esses fins. Porém, como o foco deste trabalho é o estudo da transformação martensítica induzida por deformação plástica na austenita, a análise da saturação magnética é bem aceita, porque esta propriedade só depende da fração volumétrica e não do caminho pelo qual a curva atinge a saturação.

Em suma, os resultados observados a partir dessa técnica de análise, mostram que o aço inoxidável dúplex estudado aumenta sua fração de fase magnética com a deformação, muito provavelmente pela transformação de martensita induzida por deformação na austenita. Este fato é evidenciado qualitativamente pelo aumento dos valores de saturação magnética, com o aumento do grau de deformação em relação à amostra nominalmente solubilizada (como recebida). Ainda com relação à esse aço, observa-se que as amostras com alto grau 
de laminação (93 \% de redução) promovem um maior aumento nos valores de saturação magnética. Tratamentos térmicos de 600 e $650 \stackrel{\circ}{\circ} \mathrm{C}$, ambos por 1 hora, promovem redução nestes valores e que a redução é maior para a temperatura maior. Esse fenômeno pode estar associado à reversão de martensita induzida por deformação para austenita. Quanto maior a temperatura, mais fácil o processo de difusão atômica dos elementos químicos e maior é a reversão. Entretanto, mesmo as amostras tratadas termicamente em temperaturas de $650 \stackrel{\circ}{\mathrm{C}}$ por 1 hora não retornaram aos valores iniciais de saturação magnética, sugerindo que a reversão foi apenas parcial para essas condições de tempo e temperatura de tratamento.

No caso das amostras do aço inoxidável super dúplex, não houve alterações significativas nos valores de saturação magnética para nenhum dos casos de deformação e tratamentos térmicos. Os valores permaneceram praticamente os mesmos das amostras iniciais nominalmente solubilizadas (como recebidas).

Os aços inoxidáveis super dúplex têm teores de intersticiais maiores que os dúplex, fato que aumenta a estabilidade da austenita e inibe a formação de martensita induzida por deformação para as condições de laminação que foram empregadas.

Essa mesma técnica foi utilizada para medir a magnetização do material em forma de cavaco, conforme será descrito abaixo.

A figura 4.42 apresenta histereses magnéticas do aço inoxidável dúplex UNS S31803 na forma de cavaco, conforme a escala de cores, nas condições de encruado por limagem, tratado termicamente a 600 e $650^{\circ} \mathrm{C}$, em ambos os casos, por 2 horas. 


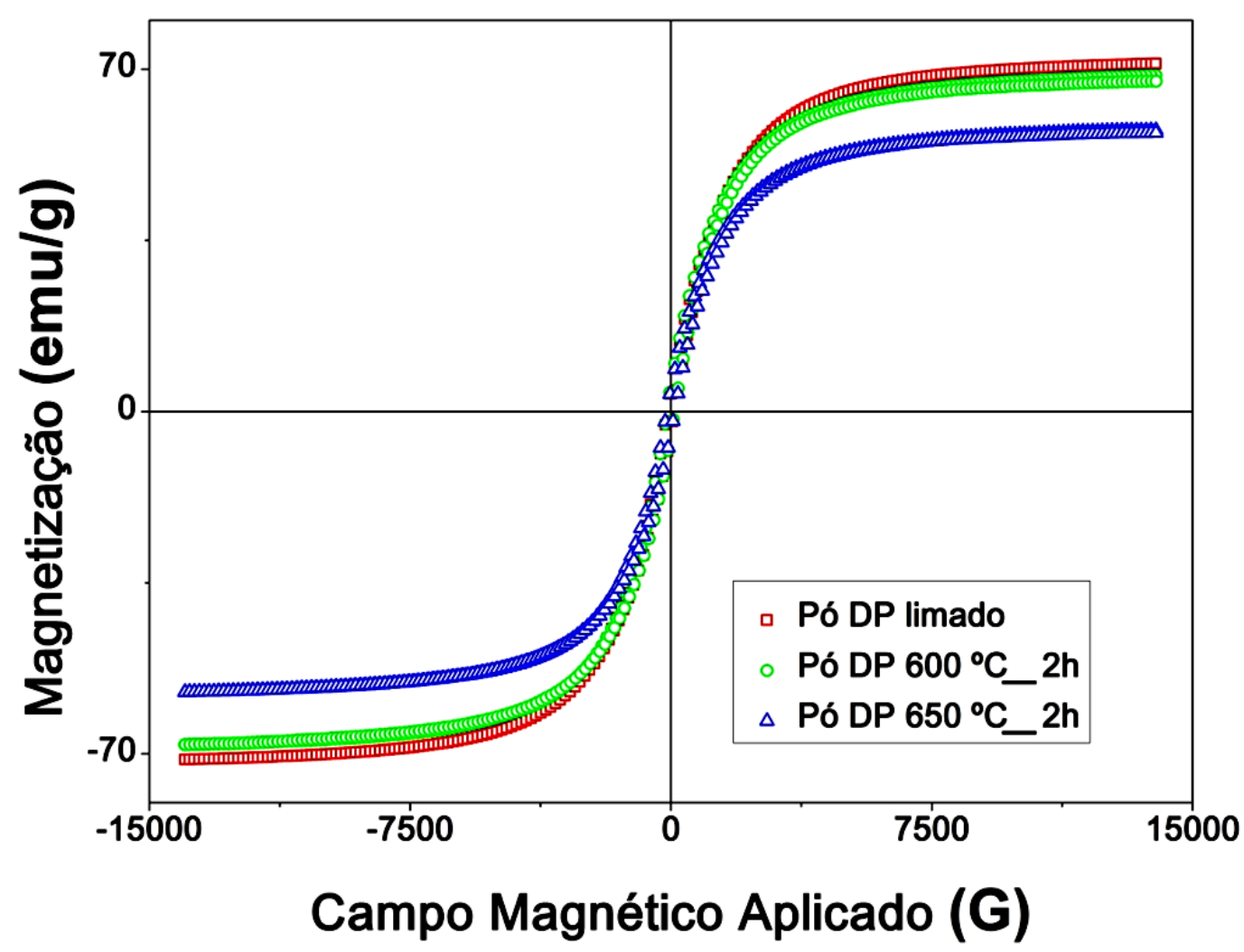

Figura 4.42 - Cavaco do aço inoxidável dúplex UNS S31803 deformado por limagem, tratado a 600 oC por 2 horas e tratado a $650 \stackrel{\circ}{\circ}$ por 2 horas.

Qualitativamente, o que pode ser observado é que o cavaco limado apresenta maior saturação magnética que os casos onde há tratamento térmico. Assim como no caso de amostras laminadas, uma bem provável transformação martensítica induzida por deformação ocorre na austenita, produzida durante o processo de limagem. Uma mudança de fase pode ser detectada pelo tratamento térmico do cavaco encruado, pois há uma diminuição dos valores de saturação magnética. Essa diminuição está associada à reversão da martensita em austenita $\mathrm{e}$ é maior para $650{ }^{\circ} \mathrm{C}$ que para $600{ }^{\circ} \mathrm{C}$, tratadas por 2 horas em ambos os casos. A explicação para esse fenômeno é a mesma dada para amostras laminadas, ou seja, quanto maior a temperatura, maior é a difusão atômica e maior o grau de reversão.

A figura 4.43 apresenta histereses magnéticas do aço inoxidável super dúplex UNS S32520 na forma de cavaco, conforme a escala de cores, nas condições de encruado por limagem, tratado termicamente a $600650 \stackrel{\circ}{\circ}$, em ambos os casos, por 2 horas. 


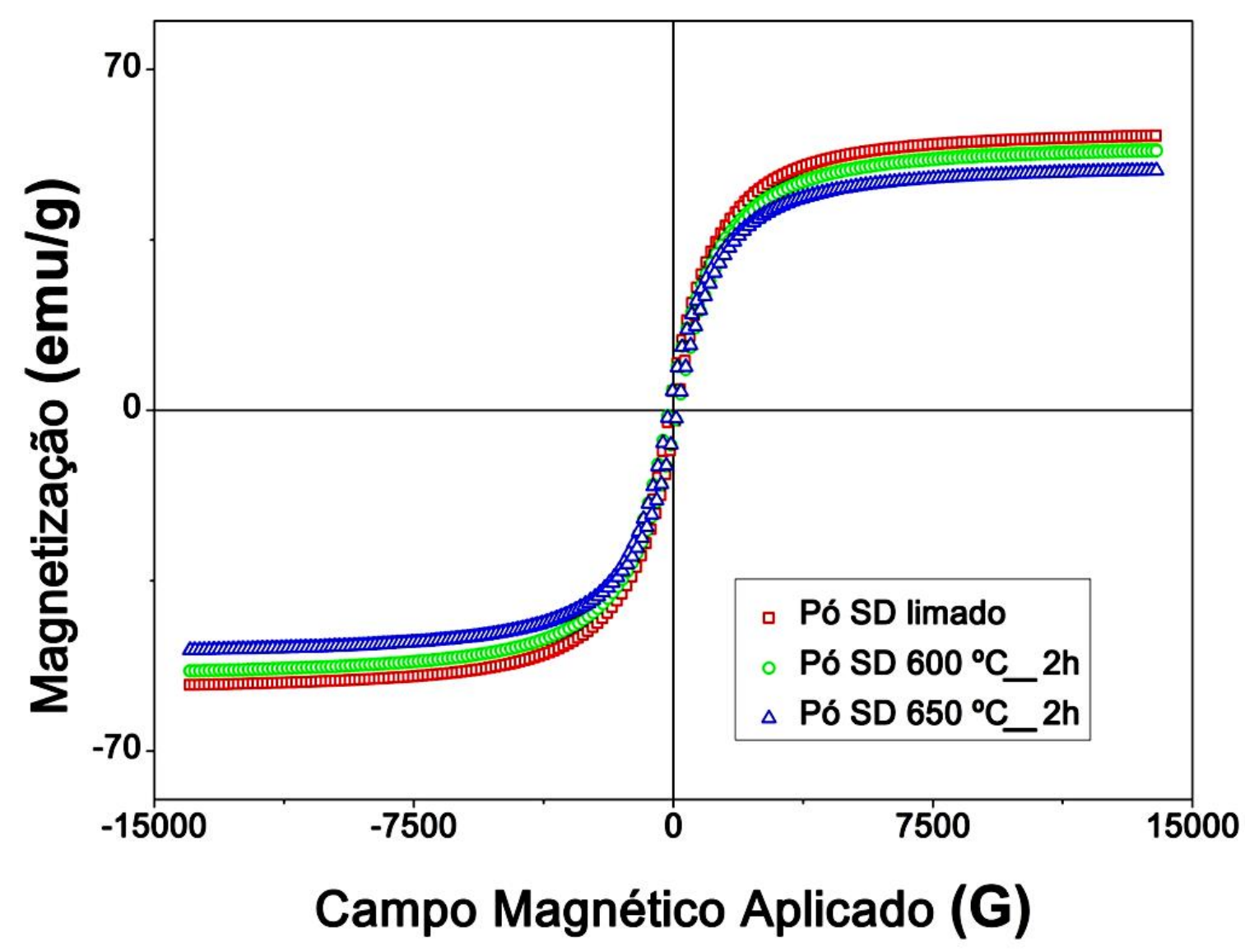

Figura 4.43 - Cavaco do aço inoxidável super dúplex UNS S32520 deformado por limagem, tratado a $600^{\circ} \mathrm{C}$ por 2 horas e tratado a $650^{\circ} \mathrm{C}$ por 2 horas.

Uma provável transformação martensítica induzida por deformação também é observada no aço inoxidável super dúplex quando deformado por limagem. Essa interpretação qualitativa é fortalecida pela reversão associada ao tratamento térmico ao observar-se a diminuição dos valores de saturação magnética, assim como ocorreu no caso anterior do aço inoxidável dúplex.

Por outro lado, ao analisar-se a escala apresentada, a fração volumétrica de martensita induzida por deformação é menor no caso do super dúplex que no dúplex, comparando a figura 4.42 e figura 4.43. Esta diferença provavelmente está relacionada com a maior presença do elemento intersticial nitrogênio na austenita do super dúplex, tornando-a menos instável.

Comparando-se os processos de limagem e laminação, nota-se que no aço inoxidável super dúplex que apenas a limagem foi capaz de transformação induzida por deformação. A transformação martensítica induzida por deformação é controlada por diversas variáveis, dentre elas a taxa e o grau de deformação. Como na laminação, até atingir a deformação final, o processo é dividido em vários estágios e 
na limagem a deformação final ocorre num único estágio, deduz-se que, a taxa de deformação da limagem é muito maior. Além disso, há uma expansão volumétrica de aproximadamente $1,5 \%$ associada à formação de martensita. O produto final da limagem, que é o cavaco, tem um maior grau de liberdade para comportar essa mudança de volume, pois na laminação o próprio posicionamento dos rolos laminadores representa uma variável a mais para restringir a transformação.

Do ponto de vista tecnológico, incluindo processamento e aplicações, podese supor que o aço inoxidável dúplex, devida à sua maior propensão de formação de martensita induzida por deformação que o aço inoxidável super dúplex, deve apresentar maior conformabilidade a frio.

Um comentário final é que, pela característica das curvas de histerese serem estreitas (baixa coercividade), para ambos os aços, tratam-se de materiais magnéticos moles. 


\section{CONCLUSÕES}

As experiências e discussões realizadas no presente trabalho permitiram as seguintes conclusões:

a) No estado inicial, solubilizado, as chapas laminadas apresentaram uma microestrutura típica de placas alternadas (lamelas em duas dimensões) de ferrita e de austenita, com grãos finos e fração volumétrica de ferrita ligeiramente menor que a de austenita. A técnica de metalografia quantitativa mostrou-se mais vantajosa para a determinação da quantidade das fases que as técnicas de difração de raios $X$ e de ferritoscopia nas amostras em forma de chapa. A presença de forte textura cristalográfica nas chapas justifica 0 pior desempenho dos dois métodos (difração de raios $\mathrm{X}$ e ferritoscopia).

b) Os parâmetros de rede da ferrita e da austenita determinados por difração de raios $X$ nos aços super dúplex são ligeiramente maiores que os do dúplex, devido um maior teor de elementos de liga.

c) Medidas de microdeformação residual determinadas por raios $\mathrm{X}$ mostraram que os cavacos limados dos dois aços estavam mais encruados que os mesmos materiais laminados até cerca de $90 \%$ de redução.

d) Pelas medidas de raios $X$ e de saturação magnética observou-se que o método de limagem levou à transformação de austenita em martensita induzida por deformação nos dois aços. Todavia, aço dúplex estudado apresentou uma fração de fase magnética maior que o super dúplex. Já pelo método de laminação, houve apenas transformação martensítica no aço inoxidável dúplex. Este comportamento pode ser justificado pelo maior teor de nitrogênio do aço e da austenita do super dúplex, estabilizando a austenita com relação à formação de martensitas induzidas por deformação. Além disso, maiores microdeformações residuais aliadas ao maior grau de liberdade do material em forma de cavaco, ajudaram a justificar a maior facilidade de transformação martensítica na limagem em comparação à laminação.

e) A despeito da similaridade cristalográfica entre a ferrita dos aços dúplex e a martensita alfa linha (CCC) induzida por deformação plástica, foi possível o 
estudo da reversão da martensita induzida por deformação para austenita nos aços inoxidáveis do tipo dúplex por difração de raios $X$ utilizando o método de Rietveld. Qualitativamente, isto também foi observado pelo método de saturação magnética.

f) Ocorreu precipitação de fase sigma durante os tratamentos térmicos tanto de $700{ }^{\circ} \mathrm{C}$, quanto de $750{ }^{\circ} \mathrm{C}$, ambos por 1 hora. A precipitação dessa fase é mais acentuada no aço super dúplex que no dúplex convencional, devido ao fato da composição química do aço super dúplex e da sua ferrita serem mais ricas em cromo e molibdênio, que aceleram a cinética de precipitação e aumentam o campo de estabilidade da fase sigma.

g) As microdeformações residuais tanto da ferrita quanto da austenita diminuíram com tratamentos térmicos em relação ao material encruado. Este decréscimo aumenta com o aumento da temperatura, exceto na ferrita no campo onde há precipitação de fase sigma. 


\section{REFERÊNCIAS BIBLIOGRÁFICAS}

1. WARD, I.A.; KEYS, L.H. Application of stress corrosion cracking theory to duplex stainless steels. In: . Proceedings Conference Stainless steel * 84, 1984, Goteborg, Sweden. Stainless steel ‘ 84, v. 1, p. $222-228,1985$.

2. FUKAURA, K.; IZUMI, H.; KAWABE, H. Tensile properties of microduplex stainless steel at low temperature. Journal of the Society of Materials Science, v. 35, p. $603-609,1986$.

3. OHMORI, Y.; NAKAI, K.; OHTSUBO, H.; ISSHIKI, Y. Mechanism of widmanstatten austenite formation in a delta/gamma duplex phase stainlesssteel. ISIJ International, v. 35, p. 969 - 975, 1995.

4. VANLELYVELD, C.D.; VANBENNEKOM, A. An evaluation of two experimental duplex $\mathrm{Cr}-\mathrm{Mn}-\mathrm{N}$ stainless steels after thermo-mechanical processing. Materials Science and Engineering A - Structural Materials Properties Microstructure and Processing, v. 205, p. 229 - 238, 1996.

5. MAKI, T. Stainless steel: Progress in thermomechanical treatment. Current Opinion in Solid State \& Materials Science, v. 2, p. 290 - 295, 1997.

6. SHIBUTANI, Y.; TANIYAMA, A.; TOMITA, Y.; ADACHI, T. Measurement of local strain-induced martensitic phase transformation by micro-hardness. Journal of the Society of Materials Science, v. 46, p. 893 - 899, 1997.

7. HE, J.; HAN, G.; FUKUYAMA, S.; YOKOGAWA, K. Tensile behaviour of duplex stainless steel at low temperatures. Materials Science and Technology, v. 15, p. $909-920,1999$.

8. ANDRADE, M.S.; VILELA, J.M.C.; GOMES, O.A.; DE CASTRO, A.L.R.; PINTO, T.B.; DE OLIVEIRA, N.J.L.; SERRANO, A.L.; DE MORAES, J.M.D. Martensite reversion in ABNT 304 austenitic stainless steel. In: .58ㅇ Congresso Anual da ABM (Associação Brasileira de Metalurgia e Materiais), 2003, 58응 Congresso Anual da ABM - Anais, 2003, p. 3155, 2003.

9. SINGH, C.D.; KUMAR, S. Texture evolution in hot band and annealed hot bands of low alloyed ferritic stainless steel. Materials Science and Technology, v. 19, p. $1037-1044,2003$.

10. WANG, Z.Y.; ZHU, J.H. Effect of primary factors on cavitation erosion resitance of some metastable austenitic metals. Acta Metallurgica Sinica, v. 39, $273-$ 277, 2003.

11. WANG, Z.Y.; ZHU, J.H. Effect of primary factor on cavitation resistance of some austenitic metals. Journal Of Iron And Steel Research International, v. 10, p. $54-58,2003$.

12. MCQUEEN, H.J.; RYAN, N.D.; ZARIPOVA, R.G. Grain refinement in austenitic and ferritic stainless steels. In: . Ultra-Fine Structured Steels, 2004, 
Hamilton, Canada. International Symposium on Ultra-Fine Structured Steels held at the 43rd Annual Conference of Metallurgists of CIM - Anais, 2004, p. 55 $-667,2004$.

13. FURUHARA, T.; MAKI, T. Grain boundary engineering for superplasticity in steels. Journal of Materials Science, v. 40, p. 919 - 926, 2005.

14. STREICHER-CLARKE, A.M.; SPEER, J.G.; MATLOCK, D.K.; DECOOMAN, B.C.; WILLIAMSON, D.L. Analysis of lattice parameter changes following deformation of a $0.19 \mathrm{C}-1.63 \mathrm{Si}-1.59 \mathrm{Mn}$ transformation-induced plasticity sheet steel. Metallurgical and Materials Transactions A - Physical Metallurgy and Materials Science, v. 36A, p. $907-918,2005$.

15. LAI, J.K.L.; LO, K.H.; SHEK, C.H.; LI, D.J. Magnetic and ageing behaviour of 7MoPLUS and the viability of monitoring ferrite decomposition using AC magnetic susceptibility. Materials Science and Engineering A - Structural Materials Properties Microstructure And Processing, v. 406, p. $110-118$, 2005.

16. FUJIWARA, H.; INOMOTO, H.; AMEYAMA, K. Formation of $(\alpha+\gamma)$ nano-duplex structure by severe plastic deformation in an SUS316L stainless steel. Journal of the Iron and Steel Institute of Japan, v. 91, p. $839-845,2005$.

17. PARK, S.H.C.; KUMAGAI, T.; SATO, Y.S.; et al. Microstructure and mechanical properties of friction stir welded 430 stainless steel. In: ISOPE 2005: Proceedings of the Fifteenth (2005) International Offshore and Polar Engineering Conference, 2005, Seoul, South Korea. $15^{\text {th }}$ International Offshore and Polar Engineering Conference (ISOPE 2005) - Anais, v. 4, p. 6 12, 2005.

18. CHIU, P.K.; WENG, K.L.; WANG, S.H.; YANG, J.R.; HUANG, Y.S.; FANG, J. Low-cycle fatigue-induced martensitic transformation in SAF 2205 duplex stainless steel. Materials Science and Engineering A, v. 398, p. $349-359$, 2005.

19. CHIU, P.K.; WANG, S.H.; YANG, J.R.; WENG, K.L.; FANG, J. The effect of strain ratio on morphology of dislocation in low cycle fatigued SAF 2205 DSS. Materials Chemistry and Physics, v. 98, p. $103-110,2006$.

20. MILITITSKY, M.; DECOOMAN, B.C.; SPEER, J.G.; DE WISPELAERE, N.; AKDUT, N. Room-temperature aging of manganese-alloyed high nitrogen duplex stainless steels. Metallurgical and Materials Transactions A: Physical Metallurgy and Materials Science, v. 37, p. 2117 - 2123, 2006.

21. TSAY, L.W.; YOUNG, M.C.; SHIN, C.; CHAN, S.L.I. Hydrogen-enhanced cracking of 2205 duplex stainless steel. Fatigue and Fracture of Engineering Materials and Structures, v. 30, p. $1228-1236,2007$.

22. LILJAS, M.; JOHANSSON, P.; LIU, H.; OLSSON, C.A. Development of a lean duplex stainless steel. Steel Research International, v. 79, p. 466 - 473, 2008. 
23. HSIAO, W.Y.; WANG, S.H.; CHEN, C.Y.; YANG, J.R.; LEE, W.S. Effects of dynamic impact on mechanical properties and microstructure of special stainless steel weldments. Materials Chemistry and Physics, v. 111, p. $172-$ 179, 2008.

24. ZHENG, Y. G.; LUO, S. Z.; KE, W. Cavitation erosion-corrosion behaviour of CrMnB stainless overlay and $0 \mathrm{Cr} 13 \mathrm{Ni}$ iso stainless steel in $0.5 \mathrm{M} \mathrm{NaCl}$ and 0.5 M HCL solutions. Tribology International, v. 41, 2008.

25. YAGODZINSKYY, Y.; SAUKKONEN, T.; ANDRONOVA, E.; RISSANEN, L.; HÄNNINEN, H. Hydrogen-induced cracking of metastable austenitic stainless and high-strength carbon steels. In: . Proceedings of the 2008 International Hydrogen Conference - Effects of Hydrogen on Materials, 2008, Grand Teton National Park, USA. International Hydrogen Conference, v. 1, p. $123-130,2009$.

26. IBRAHIM, O.H.; IBRAHIM, I.S.; KHALIFA, T.A.F. Impact behavior of different stainless steel weldments at low temperatures. Engineering Failure Analysis, v. 17, p. $1069-1076,2010$.

27. BALDO, S.; MÉSZÁROS, I. Effect of cold rolling on microstructure and magnetic properties in a metastable lean duplex stainless steel. Journal of Materials Science, v. 45, p. $5339-5346,2010$.

28. DABAH, E.; LISITSYN, V.; ELIEZER, D. Performance of hydrogen trapping and phase transformation in hydrogenated duplex stainless steels. Materials Science and Engineering A, v. 527, p. $4851-4857,2010$.

29. LAKSHMINARAYANAN, A.K.; BALASUBRAMANIAN, V. An assessment of microstructure, hardness, tensile and impact strength of friction stir welded ferritic stainless steel joints. Materials and Design, v. 31, p. $4592-4600$, 2010.

30. LAKSHMINARAYANAN, A.K.; BALASUBRAMANIAN, V. Comparison of friction stir and gas tungsten arc weldments of modified $12 \mathrm{wt} . \% \mathrm{Cr}$ ferritic stainless steel. Steel Research International, v. 81, p. 1023 - 1033, 2010.

31. CHOI, J.Y.; JI, J.H.; HWANG, S.W.; PARK, K. Strain induced martensitic transformation of Fe-20 Cr-5Mn-0.2Ni duplex stainless steel during cold rolling: Effects of nitrogen addition. Materials Science and Engineering A, v. 528, p. $6012-6019,2011$.

32. HWANG, S.W.; JI, J.H.; LEE, E.G.; PARK, K. Tensile deformation of a duplex Fe-20Mn-9Al-0.6C steel having the reduced specific weight. Materials Science and Engineering A, v. 528, p. 5196 - 5203, 2011.

33. KUOKKALA, V.; CURTZE, S.; ISAKOV, M.; HOKKA, M. Dynamic thermomechanical response of austenite containing steels. In: Conference Proceedings of the Society for Experimental Mechanics Series, 2011, Annual Conference on Experimental and Applied Mechanics - Anais, 2011, p. 
337, 2011.

34. LAKSHMINARAYANAN, A.K.; BALASUBRAMANIAN, V. Comparison of electron beam and friction stir weldments of modified $12 \mathrm{wt} \%$ ferritic stainless steel. Materials and Manufacturing Processes, v. 26, p. 868 - 877, 2011.

35. CHOI, J.Y.; JI, J.H.; HWANG, S.W.; PARK, K. Effects of nitrogen content on TRIP of Fe-20Cr-5Mn-xN duplex stainless steel. Materials Science and Engineering A, v. 534, p. $673-680,2012$.

36. CHOI, J.Y.; JI, J.H.; HWANG, S.W.; PARK, K. TRIP aided deformation of a near-Ni-free, Mn- $\mathrm{N}$ bearing duplex stainless steel. Materials Science and Engineering A, v. 535, p. $32-39,2012$.

37. LAKSHMINARAYANAN, A.K.; BALASUBRAMANIAN, V. Characteristics of Laser Beam and Friction Stir Welded AISI 409M Ferritic Stainless Steel Joints. Journal of Materials Engineering and Performance, v. 21, p. $530-539$, 2012.

38. MOSER, R.D.; SINGH, P.M.; KAHN, L.F.; KURTIS, K.E. Chloride-induced corrosion resistance of high-strength stainless steels in simulated alkaline and carbonated concrete pore solutions. Corrosion Science, v. 57, p. $241-253$, 2012.

39. PADILHA, A.F.; AGUIAR, D.J.M.; PLAUT, R.L. Duplex stainless steel: a dozen of significant phase transformation. Defect and Diffusion Forum, v. 322, p. $163-174,2012$.

40. MATSUMURA, O.; SAKUMA, T.; TAKECHI, H. Retained Austenite in 0.4C-Si1.2Mn Steel Sheet Intercrittically Heated and Austempered. ISIJ International, v. 32, p. $1014-1020,1992$.

41. HANZAKI, A. Z.; HODGSON, P. D.; YUE, S. The Influence of bainite on austenite characteristics in Si-Mn TRIP steels. ISIJ International, v. 35, p. 79 85, 1995.

42. SUGIMOTO, K.; TSUNEZAMA, M.; HOJO, T.; IKEDA, S. Ductility of 0.1-0.6C1.5Si-1.5Mn Ultra High-Strength TRIP-aided Sheet Steels with Banitic Ferrite Matrix. ISIJ International, v. 44, p. 1608 - 1614, 2004.

43. PADILHA, A.F.; PLAUT, R. L. Phase transformation and microstructure. In: ARMAS, I. A.; MOREUIL, S. D. (Ed.). Duplex stainless steels. USA: JohnWiley, 2009. chap. 3, p. 115-139.

44. WASHKO, S.D.; AGGEN, G.. In: Handbook, v.1, ed. 10, pg. $841-907,1993$.

45. DESESTRET, A.; CHARLES, J. The duplex stainless steels. In: Lacombe, P.; Baroux, B.; Beranger G. (Ed.). Stainless steels. (Translated from original 
French version "Les aciers inoxydables" by DAVIDSON, J. H. and LINDQUIST, J. B.). France: Les Editions de Physique Les Ulis, 1993. chap. 18, p. 613-658.

46. ARMAS, I. A. Duplex stainless steels: brief history and some recent alloys. Recent Patents on Mechanical Engineering, v.1, p. 51 - 57, 2008.

47. BAIN, E.C.; GRIFFITHS, E. Introduction to the iron-chromium-nickel alloys. Trans. AIME, v. 75, p. 166-213, 1927.

48. MARTINS, L. F. M.; CASTELETTI, L.C. Effect of heat treatment on the mechanical properties of ASTM A 890 Gr6A super duplex stainless steel. Materials Characterization, v. 55, p. 225 - 233, 2005.

49. REICK, W.; POHL, M.; PADILHA, A.F. Determination of stacking fault energy of austenite in a duplex stainless steel. Materials Technology: Steel Research, v. 67, p. $253-256,1996$.

50. MARTINS, L. F. M.; PLAUT, R.L.; PADILHA, A.F. Effect of carbon on the coldworked state and annealing behavior of two $18 \mathrm{wt} \% \mathrm{Cr}-8 \mathrm{wt} \% \mathrm{Ni}$ austenitic stainless steel. ISIJ International, v. 38, p. 572 - 579, 1998.

51. PADILHA, A.F.; PLAUT, R.L.; RIOS, P.R. Annealing of cold-worked austenitic stainless steels. ISIJ International, v. 43, p. $135-143,2003$.

52. HERRERA, C.; PLAUT, R.L.; PADILHA, A.F. Microstructural refinement during annealing of plastically deformed austenitic stainless steels. Materials Science Forum, v. 550, p. $423-428,2007$.

53. LIMA, N.B.; LIMA, L.M.F.G.; REICK, W.; PADILHA, A.F. Deformation and recrystallization textures in duplex stainless steel. Materials Science Forum, v. $408-412$, p. $1353-1358,2002$.

54. REICK, W.; POHL, M.; PADILHA, A.F. Recrystallization - transformation combined reactions during annealing of a cold rolled ferritic - austenitic duplex stainless steel. ISIJ International, v. 38, p. 567 - 571, 1998.

55. FOLKHARD, E. Significance of constitution diagrams for the understanding of welding phenomena. In: Welding metallurgy of stainless steels. Viena, Áustria: Springer-Verlag Wien New York, 1988. chap. 1, p. $1-51$.

56. MACHADO, I.F.; PADILHA, A.F. Effects of the addition of high nitrogen contents on the microstructure of $25 \% \mathrm{Cr}-5 \% \mathrm{Ni}$ ferritic - austenitic duplex stainless steel (DIN Wr. Nr. 1.4460). Materials Science Forum, v. 426 - 432, p. $1213-1218,2003$.

57. TAVARES, S.S.M.; SILVA, M.R.; PARDAL, J.M.; ABREU, H.F.G.; GOMES, A.M. Microstructural changes produced by plastic deformation in the UNS S31803 duplex stainless steel. Journal of Materials Processing Technology, v. 180, p. $318-322,2006$. 
58. STREICHER, M.A., Stainless Steels: Past, Present and Future. In: .Proceedings of the Stainless Steel'77 Conference, London, September 26-27, p. 1-34, 1977.

59. PADILHA, A.F; GUEDES, L.C.. In: Aços Inoxidáveis Austeníticos: microestrutura e propriedades, 3ª ed., Editora Hemus Itda, São Paulo, 1994.

60. PADILHA, A.F.; PLAUT, R. L.; RIOS, P.R.. Chapter 12: Stainless Steels Heat Treatment. In: George E. Totten (Editor). (Org.). Steel Heat Treatment: Metallurgy and Technologies. 2th ed. Boca Raton, FL, USA: CRC Press, 2007, v. 2, p. 695-739.

61. RIOS, P.R.; PADILHA, A.F.. Capítulo 1: Noções básicas de estereologia quantitativa. In: Editora, 2007, p. $\overline{13-33}$.

62. REICK, W. K.; Kaltumformung und Rekristallisation eines rostbeständigen ferritisch-austenitischen Duplex-Stahles, 1993. Tese de doutoramento (Dr.Ing.), Fakultät für Maschinenbau, Ruhr-Universität Bochum, Bochum, Alemanha, 1993.

63. DUPLEX GATE VALVE. Catálogo de válvulas Grupo Compás. Barcelona, Espanha. Disponível em: <http://alloyvalves.blog.com/tag/super-duplex-valves/ >. Acesso em 14 de novembro de 2011.

64. SEAMLESS DUPLEX STAINLESS STEEL PIPE ASTM A790 UNS S31803. Disponível em : <http://www.traderscity.com/board/products-1/offers-to-sell-andexport-1/seamless-duplex-stainless-steel-pipe-astm-a790-uns-s31803-119585/ >. Acesso em 14 de novembro de 2011.

65. COTOVELO DE TUBULAÇÃO. Disponível em: <http://www.steelpipecn.com.pt/6-pipe-fittings.html>. Acesso em 14 de novembro de 2011.

66. COMPRESSOR OIL COOLERS. Madhya Pradesh, India. Disponível em: <http://trade.indiamart.com/details.mp?offer=1746447933>. Acesso em 14 de novembro de 2011.

67. PEROXIDE REACTOR IN DUPLEX STAINLESS STEEL LDX 2101. Kappa Kraftliner, Piteå, Sweden. Disponível em: <http://www.pulpandpapertechnology.com/contractors/steel/avesta/>. Acesso em 14 novembro de 2011.

68. WHITE LIQUER TANK IN DUPLEX STAINLESS STEEL GRADE LDX 2101. Stora Enso, Finland. Disponível em: <http://www.pulpandpapertechnology.com/contractors/steel/avesta/ >. Acesso em 14 novembro de 2011.

69. CONTINUOUS KRAFT DIGESTER IN SOLID DUPLEX STAINLESS STEEL GRADE 2205. Hainan Jinhai Pulp \& Paper Co. Ltd., China. Disponível em: <http://www.pulpandpaper-technology.com/contractors/steel/avesta/>. Acesso em 14 novembro de 2011. 
70. TANQUES DE TRANSPORTE RODOVIÁRIO. Grupo Brenner, Fond du Lac, EUA. Disponível em: <http://www.brennertank.com/leanduplex>. Acesso em 14 de novembro de 2011.

71. THE CELTIC GATEWAY FOOTBRIDGE in Holyhead, UK. Disponível em: <http://www.outokumpu.com/Industry-offerings/Architecture-Building-andConstruction/Case-Studies-Container/Celtic-Gateway-Bridge-/>. Acesso em 14 de novembro de 2011.

72. PADILHA, A.F.; SICILIANO JR, F.. Capítulo 1: Introdução histórica. In: Encruamento, recristalização, crescimento de grão e textura. $3^{\mathrm{a}}$ edição revisada e ampliada. São Paulo, SP: Associação brasileira de metalurgia e materiais - ABM, 2005, p. $1-11$.

73. PADILHA, A.F.; SICILIANO JR, F.. Capítulo 2: O estado encruado. In:

Encruamento, recristalização, crescimento de grão e textura. $3^{\mathrm{a}}$ edição revisada e ampliada. São Paulo, SP: Associação brasileira de metalurgia e materiais - ABM, 2005, p. $12-28$.

74. RIOS, P.R.; PADILHA, A.F.. Capítulo 7: Transformação martensítica. In: Transformações de fase. São Paulo, SP: Artliber Editora, 2007, p. $189-204$.

75. BHADESHIA, H.K.D.H.. Chapter 2: Bainitic ferrite. In: . Bainite in steels. Transformations, microstructure and properties. $2^{\underline{a}}$ edition. London, U.K.: The University Press, Cambridge, 2001, p. $42-60$.

76. LO, K.H.; LAI, J.K.L. On the cryogenic magnetic transition and martensitic transformation of the austenite phase of 7MoPLUS duplex stainless steel. Journal of magnetism and magnetic materials. v. 322, p. $2335-2339,2010$.

77. HAESSNER,F.; PLAUT, R.L.; PADILHA, A.F. Note: Separation of static recrystallization and reverse transformation of deformed-induced martensite in austenitic stainless steel by calorimetric measurements, ISIJ International, v. 43, p 1472 - 1474, 2003.

78. OLSON, G.B.; COHEN, M. A general mechanism of martensitic nucleation: part II. FCC $\rightarrow$ BCC and other martensitic transformations, Metallurgical Transactions A, v. 7, p. $1905-1914,1976$.

79. JENSEN, D.J. Annealing textures. In: J. W. Martin Editor. Concise encyclopedia of the structure of the materials. $1^{\text {a }}$ edition. Oxford, UK. Printed in The Netherlands, 2007, p. $7-11$.

80. STÜWE, H. P.. Chapter 2: Driving and dragging forces in recrystallization. In: Frank Haessner Editor. Recrystallization of metallic materials. Stuttgart, Germany: Institut für Werkstoffkunde und Herstellungsverfahren Tescnische Universität Brausnsschweig, 1978, p. $11-21$.

81. DOHERTY, R. D. et. al. Current issues in recrystallization: a review. Materials Science and engineering A. v. 238, p. 219-274, 1197. 
82. HAESSNER,F.. Chapter 1: Systematic survey and basic problems of recrystallization. In: Frank Haessner Editor. Recrystallization of metallic materials. Stuttgart, Germany: Institut für Werkstoffkunde und Herstellungsverfahren Tescnische Universität Brausnsschweig, 1978, p. 1 - 10.

83. STÜWE, H.P.; PADILHA, A. F.; SICILIANO JR. Competition between recovery and recrystallization. Materials Science and Engineering A. v. 333, p. 361 367, 2002.

84. PADILHA, A.F.; SICILIANO JR, F.. Capítulo 12: Textura cristalográfica. In: . Encruamento, recristalização, crescimento de grão e textura. $3^{\mathrm{a}}$ edição revisada e ampliada. São Paulo, SP: Associação brasileira de metalurgia e materiais - ABM, 2005, p. $181-216$.

85. LIMA, N. B.; LIMA, L. M. G.; PADILHA, A. F.. Capítulo 7: Texturas de recristalização. In: André Paulo Tschiptschin; Angelo Fernando Padilha; e Outros. (Org.). Textura e Relações de Orientação. 2 ed. São Paulo, SP: TWA Studio Gráfico, 2003, p. 107 - 128.

86. TSCHIPTSCHIN, A. P.; GARZÓN, C. M.. Capítulo 16: Textura e relações de orientações em camadas obtidas por nitretação superficial de aços inoxidáveis em alta temperatura. In: André Paulo Tschiptschin; Angelo Fernando Padilha; e Outros. (Org.). Textura e Relações de Orientação. 2 ed. São Paulo, SP: TWA Studio Gráfico, 2003, p. 309 - 328.

87. NILSSON, J.-O.; Super duplex stainless steels. Materials Science and Technology, v. 8, p.685-700, 1992.

88. HUTCHINSON, W.B.; USHIODA, K.; RUNNSJO, G. Anisotropy of tensile behavior in a duplex stainless steel sheet. Materials Science and Technology, v. 1 , p. $728-731,1985$.

89. USHIODA, K.; HUTCHINSON, W. B. Anisotropy of tensile behavior in a duplex stainless steel sheet. Transactions of the Iron and Steel Institute of Japan, v.26, 1986.

90. KOMENDA J.; SANDSTRÖM, R. Automatic assessment of a two-phase structure in the duplex stainless-steel SAF 2205. Material Characterization,v. 31, p.155 - 165, 1993.

91. UL HAQ, A.; WEILAND, H.; BUNGE, H. Influence of ageing on the texture development of tensile-deformed duplex steel. Journal of Material Science, v. 29, p. $2168-2176,1994$.

92. UL HAQ, A.; WEILAND, H.; BUNGE, H. Textures and microstructures in duplex stainless steels. Materials Science and Technology, v.10, p. $289-298,1994$. 
93. SHEK C.H.; SHEN, G. J.; LAI, J. K. L.; DUGGAN, B. J. Texture and microstructure development in a cold-rolled duplex stainless steel annealed at $800^{\circ} \mathrm{C}$. Material Science Forum, v.157, p.853 - 858, 1994.

94. DEGALLAIX, S.; SEDdOUKI, A.; DEGALLAIX, G.; KRUML, T.; POLAK, J. Fatigue damage in austenitic-ferritic duplex stainless steels. Fatigue and Fracture of Engineering Materials and Structures, v.18, p. 65 - 77, 1995.

95. AKDUT, N.; FOOT, J. Phase boundaries and deformation in high nitrogen duplex stainless steels I. - rolling texture development. Scripta Metallurgica et Materiala, v. 32, p. $103-108,1995$.

96. AKDUT, N.; FOOT, J. Phase boundaries and deformation in high nitrogen duplex stainless steels II. - analysis of deformation mechanisms by texture measurements in X2 CrNiMo 225 (1.4462). Scripta Metallurgica et Materiala, v. 32, p. $109-114,1995$.

97. HUMPHREYS, A.O.; LI, X.; STRANGWOOD, M.; BOWEN, P.; SPENCE, M.A.; WARBURTON; G.R. Low temperature fracture behaviour of a super-duplex stainless steel (zeron 100). In: ISOPE 1996: Proceedings of the $6^{\text {th }}$ (1996) International Offshore and Polar Engineering Conference, 1996, Los Angeles, USA. $6^{\text {th }}$ International Offshore and Polar Engineering Conference (ISOPE 1996) - Anais, v. 4, p. 263 - 268, 1996.

98. AKDUT, N.; FOOT, J.; GOTTSTEIN, G. Cold rolling texture development of $\alpha / \mathrm{Y}$ duplex stainless steels. Steel Research, v. 67, p. 450 - 455, 1996.

99. SONG J.L.; BATE, P.S. Plastic anisotropy in a superplastic duplex stainless steel. Acta Materialia, v.45, p. 2747 - 2757, 1997.

100. WROBEL, M.; BONARSKI, J.; PAWLIK, K. The quantitative phase analysis of a commercial tube of the duplex stainless steel. Applied Crystallography, v. 1, p. $101-104,1998$.

101. PEDERSEN, O.B. Micromechanisms of fatigue in high nitrogen duplex steels. Materials Science Forum, v. 318, p. 733 - 742, 1999.

102. KEICHEL, J.; GOTTSTEIN, G.; FOCT, J. Recrystallization in high nitrogen alloyed super duplex stainless steel. Material Science Forum, v. 318, p. $785-$ 792, 1999.

103. AKDUT, N. Phase morphology and fatigue lives of nitrogen alloyed duplex stainless steels. International Journal of Fatigue, v. 21, p. S97 - S103, 1999.

104. PADILHA, A.F.; RANDLE, V.; MACHADO, I.F. Microstructure and microtexture changes during solution nitriding to produce austenitic case on ferritic-austenitic duplex stainless steel. Materials Science and Technology, v. 15, p. $1015-$ 1018, 1999. 
105. MARCHEV, K.; LANDIS, M.; VALLERIO, R.; COOPER, C.V.; GIESSEN, B.C.. The $m$ phase layer on ion nitrided austenitic stainless steel (III): An epitaxial relationship between the $m$ phase and the $Y$ parent phase and a review of structural identifications of this phase. Surface and Coatings Technology, v. 116 - 119, p. $184-188,1999$.

106. INAL, K.; GERGAUD, P.; FRANÇOIS, M.; LEBRUN, J.L. Stress analysis in a duplex steel. X-ray diffraction methodologies of macro and pseudo-macro stress analysis in a textured duplex stainless steel. Scandinavian Journal of Metallurgy, v. 28, p.139-150, 1999.

107. KIM, S.; MARROW, T.J. Application of electron backscattered diffraction to cleavage fracture in duplex stainless steel. Scripta Materialia, v. 40, p. $1395-$ 1400, 1999.

108. LLANES, L.; AKDUT, N.; MATEO, A.; et al. Cyclic deformation of duplex stainless steels: Microstructure and crystallographic texture effects. In:

Fatigue '99: Proceedings of the Seventh International Fatigue Congress, 1999, Beijing, China. 7th International Fatigue Congress (Fatigue '99) - Anais, v. $1-4$, p. $271-276,1999$.

109. RATUSZEK, W.; RYS, J.; CHRUSCIEL, K. Effect of deformation mode on texture development in cold-rolled duplex steel. Archives of Metallurgy, v. 44, p. $305-323,1999$.

110. JIMÉNEZ, J.A.; CARSI, M,; FROMMEYER, G.; RUANO, O.A. Characterization and mechanical properties of a delta/gamma duplex stainless steel . In:

Creep and Fracture of Engineering Materials and Structures, 1999, Japan. 8th International Conference on Creep and Fracture of Engineering Materials and Structures - Anais, v. $171-1$, p. $389-394,2000$.

111. BONARSKI, J.T.; WRÓBEL, M.; PAWLIK, K. Quantitative phase analysis of duplex stainless steel using incomplete pole figures. Materials Science and Technology, v. 16, p. $657-662,2000$.

112. JOHANSSON, J.; ODÉN, M. Load sharing between austenite and ferrite in a duplex stainless steel during cyclic loading. Metallurgical and Materials Transaction A - Physical Metallurgy and Material Science, v. 31, 1557 1570, 2000.

113. JIMENEZ, J.A.; CARSI, M.; RUANO, O.A.; PEÑALBA, F. Characterization of a $\delta / y$ duplex stainless steel. Journal of Material Science, v. 35, p. $907-915$, 2000.

114. RATUSZEK, W.; RYS, J.; KARNAT, M. Annealing textures in cold-rolled duplex type steel. Archives of Metallurgy, v. 45, p. $57-70,2000$.

115. MATEO, A.; LLANES, L.; AKDUT, N.; ANGLADA, M. High cycle fatigue behavior of a standard duplex stainless steel plate and bar. Materials Science and Engineering A, v. $319-321$, p. $516-520,2001$. 
116. JIMÉNEZ, J.A.; FROMMEYER, G.; CARSÍ, M.; RUANO, O.A. Superplastic properties of a $\delta / Y$ stainless steel. Materials Science and Engineering $A$, $v$. 307, p. $134-142,2001$.

117. RATUSZEK, W.; RYS, J.; WITKOWSKA, M.; et al. The effect of phase transformations on texture development in duplex steel. Applied Crystallography, v. 1, p. $263-268,2001$.

118. TSCHIPTSCHIN, A.P.; GARZÓN, C.M.; LIMA, N.B. Texture evolution during high temperature gas nitriding of duplex stainless steels. Materials Science Forum, v. $408-412$, p. $1347-1352,2002$.

119. DUPREZ, L.; DE COOMAN, B.C.; AKDUT, N. Deformation behaviour of duplex stainless steel during industrial hot rolling. Steel Research, v. 73, p. $531-538$, 2002.

120. MOVERARE, J.J.; ODÉN, M. Deformation behavior of a prestrained duplex stainless steel. Materials Science and Engineering A, v. 337, p. $25-38$, 2002.

121. MOVERARE, J.J.; ODÉN, M. Influence of elastic and plastic anisotropy on the flow behavior in a duplex stainless steel. Metallurgical and Materials Transaction A - Physical Metallurgy and Material Science, v. 33, p. $57-71$, 2002.

122. GOURGUES, A.F. Electron backscatter diffraction and cracking. Materials Science and Technology, v.18, p. 119-133, 2002.

123. KEICHEL, J.; FOCT, J.; GOTTSTEIN, G. Deformation and annealing behavior of nitrogen alloyed duplex stainless steels. part I: Rolling. ISIJ International, v. 43, p. $1781-1787,2003$.

124. KEICHEL, J.; FOCT, J.; GOTTSTEIN, G. Deformation and annealing behavior of nitrogen alloyed duplex stainless steels. part I: Rolling. ISIJ International, v. 43, p. $1788-1794,2003$.

125. ETTER, A.L.; MATHON, M.H.; BAUDIN, T.; PENELLE, R. Stored energy evolution as a function of cold rolling reduction for a fe-53\%Ni alloy and an austenitic-ferritic steel. Revue de Metallurgie.Cahiers D'Informations Techniques, v. 100, p. $851-858,2003$.

126. MATEO, A.; LLANES, L.; AKDUT, N.; STOLARZ, J. ANGLADA, M. Anisotropy effects on the fatigue behaviour of rolled duplex stainless steels. International Journal of Fatigue, v. 25, p. $481-488,2003$.

127. RAABE, D. Overview on basic types of hot rolling textures of steels. Steel Research International, v. 74, p. $327-337,2003$.

128. GIRONÈS, A.; VILLECHAISE, P.; MATEO, A.; ANGLADA, M.; MÉNDEZ, J. EBSD studies on the influence of texture on the surface damage mechanisms 
developed in cyclically loaded aged duplex stainless steels. Materials Science and Engineering A, v. 387 - 389, p. 516 - 521, 2004.

129. KRIZAN, D.; DUPREZ, L.; DE COOMAN, B.C. Properties of laser welded SAF 2205 duplex stainless steel sheet. Steel Research International, v.75, p. 829 835, 2004.

130. LADWEIN, T.L.; AALEN, F.; GÜMPEL, P.; KONSTANZ, F. The influence of functional surface properties of stainless steels on corrosion. Corrosion 2004, 2004.

131. WITKOWSKA, M.; RATUSZEK, W.; RYS, J.; et al. Factors affecting annealing textures in duplex type steels. Applied Crystallography, v. 1, p. $185-189$, 2004.

132. INAL, K.; LEBRUN, J.L.; BELASSEL, M. Second-order stresses and strains in heterogeneous steels: Self-consistent modeling and X-ray diffraction analysis. Metallurgical and Materials Transaction A - Physical Metallurgy and Material Science, v. 35A, p. 2361 - 2369, 2004.

133. BACZMANSKI, A.; BRAHAM, C.; SEILER, W. Evolution of plastic incompatibility stresses in duplex stainless steel determined by $\mathrm{X}$-ray diffraction. Physica Status Solidi A - Applied Research, v. 201, p. 2886 - 2899, 2004.

134. RYŚ, J.; RATUSZEK, W.; WITKOWSKA, M. Rolling texture development in duplex type steel with strong initial texture. Archives of Metallurgy and Materials, v. 50, p. $857-870,2005$.

135. BLICHARSKI M, JURA J, BAUDIN T, PENELLE R, BONARSKI J, KOWALSKI $M$. Development of the orientation relationship between ferritic and austenitic phases during long time annealing of duplex stainless steel. Archives of Metallurgy and Materials, v. 50, p. $495-502,2005$.

136. WITKOWSKA, M.; RYŚ, J.; RATUSZEK, W.; ZIELIŃSKA-LIPIEC, A. Annealing textures and precipitation behaviour in ferritic-austenitic duplex type steels. Archives of Metallurgy and Materials, v. 50, p. $471-478,2005$.

137. GARZÓN, C.M.; THOMAS, H.; DOS SANTOS, J.F.; TSCHIPTSCHIN, A.P. Cavitation erosion resistance of a high temperature gas nitrided duplex stainless steel in substitute ocean water. Wear, v. 1 -6, p. $145-153,2005$.

138. MIRANDA, M.A.R.; SASAKI, J.M.; TAVARES, S.S.M.; DE ABREU, H.F.G.; NETO, J.M. The use of X-ray diffraction, microscopy, and magnetic measurements for analysing microstructural features of a duplex stainless steel. Materials Characterization, v. 54, p. $387-393,2005$.

139. ZHANG, P.; REN, X.; XIE, J.; ZHANG, B.; HAN, W.; SONG, J. Superplasticity mechanism of duplex stainless steels. Journal of University of Science and Technology Beijing, v. 27, p. $68-71,2005$. 
140. RYS, J.; RATUSZEK, W.; WITKOWSKA, M . The effect of initial orientation and rolling schedule on texture development in duplex steel. Materials Science Forum, v. $495-497$, p. $375-380,2005$.

141. SATO, Y.S.; NELSON, T.W.; STERLING, C.J.; et al. Microstructure and mechanical properties of friction stir welded SAF 2507 super duplex stainless steel. Materials Science And Engineering A - Structural Materials Properties Microstructure And Processing, v. 397, p. 376 - 384, 2005.

142. GARZÓN, C.M.; TSCHIPTSCHIN, A.P. EBSD texture analysis of a high temperature gas nitrided duplex stainless steel. Materials Science and Engineering A, v. 441, p. $230-238,2006$.

143. JIA, N.; PENG, R.L.; WANG, Y.D.; CHAI, G.C.; JOHANSSON, S.; WANG, G.; et al. Interactions between the phase stress and the grain-orientationdependent stress in duplex stainless steel during deformation. Acta Materialia, v. 54 , p. $3907-3916,2006$.

144. CIZEK, P.; WYNNE, B.P.; RAINFORTH, W.M. EBSD investigation of the microstructure and texture characteristics of hot deformed duplex stainless steel. Journal of Microscopy, v. 222, p. 85 - 96, 2006.

145. HERRERA, C.; LIMA, N.B.; PADILHA, A.F. Texture and relationships of orientation in duplex stainless steels. Metalurgia e Materiais, v. 62, p. $158-$ $161,2006$.

146. CIZEK, P.; WYNNE, B.P. RAINFORTH, W.M. EBSD investigation of the effect of strain path changes on the microstructure and texture of duplex stainless steel during hot deformation. Journal of Physics: Conference Series, v. 26, p. $331-334,2006$.

147. DAKHLAOUI, R.; BRAHAM, C.; BACZMANSKI, A.; et al. Effect of residual stresses on mechanical properties of duplex stainless steel studied by diffraction and self-consistent modeling. Materials Science Forum, v. $524-$ 525, p. $185-190,2006$.

148. RYS, J.; RATUSZEK, W.; WITKOWSKA, M. Comparison of the rolling texture formation in duplex steels with various initial textures. Archives of Metallurgy and Materials, v. 51, p. $495-502,2006$.

149. RYS, J.; RATUSZEK, W.; WITKOWSKA, M. Rolling texture differences in duplex steels with strong and random initial Orientations. Applied Crystallography, v. 130, p. $57-62,2007$.

150. HILDERS, O.A.; RAMOS, M.; PEÑA, N.D.; BERRÍO, L.; ICHASO, A. Fracture morphology study of a duplex stainless steel isothermically aged at $475{ }^{\circ} \mathrm{C}$. Revista Facultad de Ingeniería, v. 22, p. 61-69, 2007.

151. HEMPSCH, A, SCHMITT G, BLECK W. Advances in assessing the susceptibility to intergranular corrosion (IGC) of austenitic and duplex stainless 
steels using the electrochemical reactivation test (ERT). Corrosion 2007, v. 4, p. $2386-2396,2007$.

152. QIN, H.; HU, C.; YAN, L.; ZHANG, J.; ZHU, J. Effect of GTAW welding on texture of welded joint of SAF2205 steel plate. Journal of Northeastern University, v. 28, p. $95-96,2007$.

153. CHANDRAMOHAN, P.; NAZIRUDCCN, S.S.M.; RNINAKRISHNAN, S.S. Hot forging of nitrogen alloyed duplex stainless steels. Journal of Materials Science and Technology, v. 23, p. $111-117,2007$.

154. CAILLETAUD, G. An introduction to crystalline plasticity and its interaction with the environment. In: PLASTOX 2007: Mecanismes Et Mecanique Des Interactions Plasticite-Environnement, 2007, Argeles sur Mer, France. Conference on Mechanisms and Mechanics of Plasticity - Environment Interactions - Anais, v. 1, p. 81 - 115, 2007.

155. WRONSKI, S.; BACZMANSKI, A.; DAKHLAOUI, R.; et al. Determination of the stress field in textured duplex steel using the TOF neutron diffraction method. Acta Materialia, v. 55, p. $6219-6233,2007$.

156. Hou, C.; Liu, C. Effect of cold rolled reduction on the texture and plastic strain ratio of 2205 duplex stainless steel. In: Rollett, A.D. (Ed.). Materials Processing and Texture. John-Wiley \& Sons. Chap. 20, 2008, p. $203-213$.

157. FARGAS, G.; AKDUT, N.; ANGLADA, M.; MATEO, A. Microstructural evolution during industrial rolling of a duplex stainless steel. ISIJ International, v. 48, p. 1596 - 1602, 2008.

158. MORRI, A. Heat treatments of two-phase titanium alloys, correlations between microstructure and mechanical properties. Metallurgia Italiana, v. 100, p. $1-$ 57, 2008.

159. SOUZA JR, C.M.; ABREU, H.F.G.; TAVARES, S.S.M.; REBELLO, J.M.A. The $\sigma$ phase formation in annealed UNS S31803 duplex stainless steel: Texture aspects. Materials Characterization, v. 59, p. $1301-1306,2008$.

160. BAMOULID, L.; MAURETTE, M.; DE CARO, D.; GUENBOUR, A.; BEN BACHIR, A.; ARIES, L.; et al. An efficient protection of stainless steel against corrosion: Combination of a conversion layer and titanium dioxide deposit. Surface and Coatings Technology, v. 202, p. 5020 - 5026, 2008.

161. HERRERA, C.; PONGE, D.; RAABE, D. Characterization of the microstructure, crystallographic texture and segregation of an as-cast duplex stainless steel slab. Steel Research International, v. 79, p. $482-488,2008$.

162. RYŚ, J.; WITKOWSKA, M. Rolling texture development in nitrogen alloyed ferritic-austenitic steel of duplex type. Archives of Metallurgy and Materials, v. 53, p. $221-228,2008$. 
163. CHANDRAMOHAN, P.; MOHAMED-NAZIRUDEEN, S.S.; RAMAKRISHNAN, S.S. Studies on production and thermo-mechanical treatment of $0.32 \%$ nitrogen alloyed duplex stainless steel. Journal of Materials Engineering and Performance, v. 17, p. $271-279,2008$.

164. RUIZ, A.; ORTIZ, N; CARREÓN, H.; SÁNCHEZ, A.; BEDOLLA, A. Analysis of shear wave acoustic velocity in 2205 duplex stainless steel. Review of Quantitative Nondestructive Evaluation, v. 27, p. 1170 - 1175, 2008.

165. JIA, N.; WANG, Y.D.; PENG, R.L. Micromechanical behaviors of duplex steel: In situ neutron diffraction measurements and simulations. Journal of Physics Condensed Matter, v. 20, p. 104259 - 104265, 2008.

166. JIA, N.; LIN PENG, R.; WANG, Y.D.; JOHANSSON, S.; LIAW, P.K. Micromechanical behavior and texture evolution of duplex stainless steel studied by neutron diffraction and self-consistent modeling. Acta Materialia, v. 56, p. $782-793,2008$.

167. HERRERA, C.; LIMA, N.B.; KLIAUGA, A.M.; PADILHA, A.F. Microstructure and texture of duplex stainless steel after melt-spinning processing. Materials Characterization, v. 59, p. $79-83,2008$.

168. WITKOWSKA M.; RATUSZEK, W.; RYS, J.; et al. The effect of deformation and annealing on sigma phase precipitation in duplex steels. Archives of Metallurgy and Materials, v. 53, p. $289-294,2008$.

169. OGI, H.; INOUE, T.; NAGAI, H.; et al . Quantitative imaging of Young's modulus of solids: A contact-mechanics study. Review Of Scientific Instruments, v. 79, Article Number: 053701, DOI: 10.1063/1.2908437, 2008.

170. JIA, N.; PENG, R.; LIN CHAI, G. C.; et al. Direct experimental mapping of microscale deformation heterogeneity in duplex stainless steel. Materials Science And Engineering A - Structural Materials Properties Microstructure And Processing, v. 491, p. 425 - 433, 2008.

171. BACZMANSKI, A.; LIPINSKI, P.; TIDU, A.; et al. Quantitative estimation of incompatibility stresses and elastic energy stored in ferritic steel. Journal Of Applied Crystallography, v. 41, p. $854-867,2008$.

172. EL BARTALI, A.; AUBIN, V.; SABATIER, L.; et al. Identification and analysis of slip systems activated during low-cycle fatigue in a duplex stainless steel. Scripta Materialia, v. 59, p. $1231-1234,2008$.

173. RYŚ, J.; WITKOWSKA, M. The effect of starting orientations and initial morphology on texture formation in duplex steel saf 2205. Archives of Metallurgy and Materials, v. 54, p. $789-803,2009$.

174. LI, J.; DENG, B.; JIANG, Y. Investigation and applications of corrosion evaluating technologies for stainless steels. Corrosion and Protection, v. 30, p. $595-603,2009$. 
175. GARCíA, R. L.; PORTERO, M. J. M.; GARCíA, J. A. Evaluation of alloy 146, 279,900 , and 926 sensitization to intergranular corrosion by means of electrochemical methods and image analysis. Corrosion Science, v. 51, p. 2080 - 2091, 2009.

176. HAN, D.; JIANG, Y.; DENG, B.; ZHANG, L.; ZHANG, W.; LI, J. Effect of aging time on electrochemical corrosion behavior of 2101 duplex stainless steel. Acta Metallurgica Sinica, v. 45, p. 919 - 923, 2009.

177. MESA, D.H.; GARZÓN, C.M.; TSCHIPTSCHIN, A.P. Mesoscale plasticity anisotropy at the earliest stages of cavitation-erosion damage of a high nitrogen austenitic stainless steel. Wear. V. 267, p. 99 - 103, 2009.

178. MATSUSHITA, M.; SUKO, T.; MATSUDA, S.; OHFUJI, H.; OGIYAMA, H. Analysis of the texture of superplastic carburized duplex stainless alloy. Material Chemical Physic, v. 114, p. 522 - 524, 2009.

179. CHANDRAMOHAN, P.; SUBRAMANIAN, K.M.; CHANDRASEKAR, P. Rolling process with OHSAS and texture formation - A review. Journal of Engineering Science And Technology, v. 4, p. 1 - 19, 2009.

180. MENEZES, J.W.A.; ABREU, H.; KUNDU, S.; BHADESHIA, H.K.D.H.; KELLY, P.M. Crystallography of widmanstätten austenite in duplex stainless steel weld metal. Science and Technology of Welding and Joining, v. 14, p.4 -10, 2009.

181. GARCÍA, C.; MARTíN, F.; BLANCO, Y.; DE TIEDRA, M.P.; APARICIO, M.L. Corrosion behaviour of duplex stainless steels sintered in nitrogen. Corrosion Science, v. 51, p. $76-86,2009$.

182. HOU, C.K.; LIU, C.C. Effect of cold rolled reduction on the texture and plastic strain ratio of 2205 duplex stainless steel. Materials Processing and Texture, v. 200, p. $183-192,2009$.

183. PARK, S.H.C.; SATO, Y.S.; KOKAWA, H.; et al. Boride Formation Induced by pcBN Tool Wear in Friction-Stir-Welded Stainless Steels. Metallurgical and Materials Transaction A -Physical Metallurgy and Material Science, v. 40A, p. $625-636,2009$.

184. MESA, D.H.G.; GARZON, C.M.O.; TSCHIPTSCHIN, A.P. Mesoscale plasticity anisotropy at the earliest stages of cavitation-erosion damage of a high nitrogen austenitic stainless steel. Wear, v. 267, p. $99-103,2009$.

185. PESCI, R.; INAL, K.; MASSON, R. Three scale modeling of the behavior of a 16MND5-A508 bainitic steel: Stress distribution at low temperatures. Materials Science And Engineering A - Structural Materials Properties Microstructure And Processing, v. 527, p. 376 - 386, 2009. 
186. DE MARCO, M.; MANDINA, M.; MURGIA, M. Effetti metallurgici dei trattamenti termici negli acciai inossidabili ai solo cromo, al cromo-nichel ed indurenti per precipitazione. Rivista Italiana Della Saldatura, v. 62, p. 577 - 588, 2010.

187. RYŚ, J.; RATUSZEK, W. Rolling texture formation in super-duplex stainless steel. Applied Crystallography, v. 163, p. 145 - 150, 2010.

188. RYŚ, J.; WITKOWSKA, M. Microstructure and deformation behavior of coldrolled super-duplex stainless steel. Applied Crystallography, v. 163, p. 151 156, 2010.

189. HIROTA, N.; YIN, F.; AZUMA, T.; INOUE, T. Yield stress of duplex stainless steel specimens estimated using a compound hall-petch equation. Science and Technology of Advanced Materials, v. 11, article no 025004, 2010.

190. GONG, J.; JIANG, Y.M.; DENG, B.; XU, J.L.; HU, J.P.; LI, J. Evaluation of intergranular corrosion susceptibility of UNS S31803 duplex stainless steel with an optimized double loop electrochemical potentiokinetic reactivation method. Electrochimical Acta, v. 55, p. 5077 - 5083, 2010.

191. BARELLA, S.; MAPELLI, C.; RIVA, R.F. Texture and mechanical properties of duplex stainless steel through symmetric hot rolling. Revue De Metallurgie.Cahiers D'Informations Techniques, v. 107, p. 275 - 291, 2010.

192. CHAN, W.K.; KWOK, C.T.; LO, K.H.; CHENG, Z. Desensitization of austenitic and duplex stainless steels by laser surface melting. In: PICALO 2010, Wuhan, Republic of China. 4th pacific international conference on applications of lasers and optics - Anais, Paper number 806, 2010.

193. HAMADA, J.; ONO, N. Effect of microstructure before cold rolling on texture and formability of duplex stainless steel sheet. Materials Transactions, v. 51, p. $635-643,2010$.

194. HAMADA, J.; INOUE, H. Texture and planar anisotropy of $r$-value in duplex stainless steel sheet. Materials Transactions, v. 51, p. $644-651,2010$.

195. SAEID, T.; ABDOLLAH-ZADEH, A.; SHIBAYANAGI, T.; IKEUCHI, K.; ASSADI, $H$. EBSD investigation of friction stir welded duplex stainless steel. World Academy of Science, Engineering and Technology, v. 61, p. $376-379,2010$.

196. XU, J.; DENG, B.; SUN, T.; LI, J.; JIANG, Y. Evaluation of the susceptibility to intergranular attack of 2205 duplex stainless steel by DL-EPR method. Acta Metallurgica Sinica, v. 46, p. $380-384,2010$.

197. DENG, B.; JIANG, Y.; XU, J.; SUN, T.; GAO, J.; ZHANG, L.; et al. Application of the modified electrochemical potentiodynamic reactivation method to detect susceptibility to intergranular corrosion of a newly developed lean duplex stainless steel LDX2101. Corros Science, v. 52, p. 969 - 977, 2010. 
198. LEIVA, R. G.; MUÑOZ, M.J.P.; GARCÍA, J.A. Corrosion behaviour of sensitized and unsensitized alloy 900 (UNS 1.4462) in concentrated aqueous lithium bromide solutions at different temperatures. Corrosion Science, v. 52, p. $950-$ 959, 2010.

199. CAILLETAUD, G. Basic ingredients, development of phenomenological models and practical use of crystal plasticity. Multiscale Modelling of Plasticity and Fracture by Means of Dislocation Mechanics, v. 522, p. 271 - 326, 2010.

200. FARNOUSH, H.; MOMENI, A.; DEHGHANI, K.; et al. Hot deformation characteristics of 2205 duplex stainless steel based on the behavior of constituent phases. Materials \& Design, v. 31, p. 220 - 226, 2010.

201. RYS, J.; WITKOWSKA, M. Influence of band-like morphology on microstructure and texture evolution in rolled super-duplex steel. Archives of Metallurgy and Materials, v. 55, p. $733-747,2010$.

202. DAKHLAOUI, R.; KLOSEK, V.; MATHON, M. H.; et al. Orientation stress field analysis in polycrystalline bcc steel using neutron diffraction Acta Materialia, v. 58, p. $499-509,2010$.

203. SAEID, T.; ABDOLLAH-ZADEH, A.; SHIBAYANAGI, T.; et al. On the formation of grain structure during friction stir welding of duplex stainless steel. Materials Science and Engineering A - Structural Materials Properties Microstructure and Processing, v. 527, p. 6484 - 6488, 2010.

204. MESA, D. H.; PINEDO, C. E.; TSCHIPTSCHIN A. P. Improvement of the cavitation erosion resistance of UNS $\mathrm{S} 31803$ stainless steel by duplex treatment. Surface \& Coatings Technology, v. 205, p. 1552 - 1556, 2010.

205. WAWSZCZAK, R.; BACZMANSKI, A.; BRAHAM, C.; et al. Residual stress field in steel samples during plastic deformation and recovery processes. Philosophical Magazine, v. 91, p. 2263 - 2290, 2011.

206. CAM G. Friction stir welded structural materials: beyond Al-alloys. International Materials Reviews, v. 56, p. $1-48,2011$.

207. MARINELLI, M. C.; MOSCATO, M. G.; SIGNORELLI, J. W.; et al. K-S relationship identification technique by EBSD. Materials Structure \& Micromechanics Of Fracture, v. 465, p. 415-418, 2011.

208. JIN X; MA S; MA Y; et al. Duplex chain cutter-type orchard fertilization ditching machine for use in e.g. fruit industry, has chain cutting boards uniformly distributed on chain at intervals, and rack whose upper end is hinged with rear end of drawing machinery Patent Number: CN202005140-U Patent Assignee: URUMCHI MUTIANYUAN AGRIC SCI\&TECHNOLOGY CO LTD .

209. MOMENI, A.; DEHGHANI, K. Hot working behavior of 2205 austenite-ferrite duplex stainless steel characterized by constitutive equations and processing 
maps. Materials Science And Engineering A - Structural Materials Properties Microstructure And Processing, v. 528, p. 1448 - 1454, 2011.

210. FONDA, R. W.; KNIPLING, K. E. Texture development in friction stir welds. Science and Technology of Welding and Joining, v. 16, p. $288-294,2011$.

211. HERRERA, C.; PONGE, D.; RAABE, D. Design of a novel Mn-based $1 \mathrm{GPa}$ duplex stainless TRIP steel with $60 \%$ ductility by a reduction of austenite stability Acta Materialia, v. 59, p. 4653 - 4664, 2011.

212. MESA, D. H.; GARZON, C. M.; TSCHIPTSCHIN, A. P. Influence of cold-work on the cavitation erosion resistance and on the damage mechanisms in highnitrogen austenitic stainless steels. Wear, v. 271, p. $1372-1377,2011$.

213. BADJI, R.; BACROIX, B.; BOUABDALLAH, M. Texture, microstructure and anisotropic properties in annealed 2205 duplex stainless steel welds. Materials Characterization, v. 62, p. $833-843,2011$.

214. ELMASSALAMI, M.; SOUSA, I. P.; AREIZA, M. C. L.; et al. On the magnetic anisotropy of superduplex stainless steel. Journal of Magnetism and Magnetic Materials, v. 323, p. 2403 - 2407, 2011.

215. FARGAS, G.; AKDUT, N.; ANGLADA, M.; et al. Reduction of anisotropy in coldrolled duplex stainless steel sheets by using sigma phase transformation. Metallurgical and Materials Transaction A - Physical Metallurgy and Material Science, v. 42A, p. 3472 - 3483, 2011.

216. SUBRAMANIAN, K.; CHANDRAMOHAN, P.; RAVISANKAR, B. Influence of texture on the mechanical properties of hot rolled duplex stainless steels. Transactions of the Indian Institute of Metals, v. 64, p. $519-534,2011$.

217. JIA, N.; PENG, R. L.; WANG, Y. D.; et al. Self-consistent modeling of rolling textures in an austenitic-ferritic duplex steel. Materials Science and Engineering A - Structural Materials Properties Microstructure and Processing, v. 528, p. $3615-3624,2011$.

218. MOMENI, A.; DEHGHANI, K.; ZHANG, X. X. Mechanical and microstructural analysis of 2205 duplex stainless steel under hot working condition. Journal of Materials Science, v. 47, p. 2966 - 2974, 2012.

219. CULLITY, B. D.; GRAHAM, C. D. Introduction to magnetic materials. Hoboken, New Jersey, USA: Published by John Wiley \& Sons, Inc., 2nd ed., 2009.

220. FARIA, R. N.; LIMA, L. F. C. P. Introdução ao magnetismo dos materiais. São Paulo, São Paulo: Ed. Livraria da Física, 2005.

221. SCHAEFFLER A. L. Selection of austenitic electrodes for welding dissimilar metals", Welding Journal, v. 26, Research Supplement, p. 603s-620s, 1947. 
222. SCHAEFFLER A. L. Welding dissimilar metals with stainless electrodes, Iron Age, v 162, p. 73 - 79, 1948.

223. SCHAEFFLER A. L. Constitution diagram for stainless steel, Metal Progress, v. 56 , p. $680-680 B, 1949$.

224. DeLONG W. T. Ferrite in austenitic stainless steel weld metal, Welding Journal, v. 53, Research Supplement, p. 273s - 286s, 1974.

225. DAVIS J. R. (EDITOR). In:

Steels, Ohio, USA, ASM International, 1994.

226. LOPEZ, N.; CID, M.; PUIGGALI, M. Influence of $\sigma$-phase on mechanical properties and corrosion resistance of duplex stainless steels, Corrosion Science, v. 41, p. 1615 - 1631, 1999.

227. RAVINDRANATH, K.; MALHOTRA, S. N. The influence of aging on the intergranular corrosion of 22 chromium - 5Ni duplex stainless steel, Corrosion Science. v.1, p. $121-132,1995$.

228. MAGNABOSCO, R.; FALLEIROS, N.A. Efeito de longos tempos de aquecimento a $850^{\circ} \mathrm{C}$ sobre resistência à corrosão do aço UNS S31803 em meio ácido e meio aquoso contendo cloreto. In: __ 6 - COTEC Conferência de Tecnologia de Equipamentos, 2002, Salvador, BA. $6^{\underline{a}}$ COTEQ - Anais, 2002.

229. MACHADO, I. F; PADILHA, A. F. Aging behavior of $25 \mathrm{Cr}-17 \mathrm{Mn}$ high nitrogen duplex stainless steel, ISIJ International, v. 40, nำ 7, p. 719 - 724, 2000.

230. ZUCATO, I.; MOREIRA, M. C.; MACHADO, I. F.; LEBRÃO, S. M. G. Microestructural characterization and effect of phase transformations on toughness of the UNS S31803 duplex stainless steel aged at $850{ }^{\circ} \mathrm{C}$, Materials Research, v. 5, p. $385-389,2002$.

231. YANG, H.; HUANG, L.; BAKKER, H. Phase transformations in sigma phases by mechanical milling, Material Science Forum, v. 150 - 151, 1994.

232. VORONENKO, B.I.; Austenitic-ferritic stainless steels: A state-of-the-art review, Material Science and heat treatment, vol. 39, p. 428 - 437, 1997.

233. CHANDRA, T.; KUCHLMAYR, R. Effect of strain rate on sigma formation in ferrite-austenite stainless steel at high temperatures, Journal of Materials Science, v. 23, p. $723-728,1988$.

234. AGUIAR, D.J.M. Processamento do aço inoxidável super dúplex UNS S32520 por moagem de alta energia. Dissertação (Mestrado em Ciência e Engenharia de Materiais) Universidade Estadual de Ponta Grossa, Ponta Grossa, 2008.

235. GUNN, R.N. Chapter 3: Microstructure. In: GUNN, R. N. (Editor). Duplex 
stainless steels: microstructure, properties and applications. 1st ed. Cambridge, Engalnd: Abington Publishing, 1997, v. 1, p.24 - 49.

236. PADILHA, A.F.; FILHO, F.A. Técnicas de análise microestrutural. São Paulo, Brasil: Editora Hemus, 2004.

237. . ASTM E - $562-02$ - Standard test method for determining volume fraction by systematic manual point. American Society for Testing and Materials. West Conshohocken, v. 03.01, 2005.

238. . ASTM E - 112 - Standard Test Methods for Determining Average Grain Size. American Society for Testing and Materials. West Conshohocken, v. 03.01, 2005.

239. SCHRAMM, R.E.; REED, R.P. Stacking fault energies of seven commercial austenitic stainless steels. Metallurgical Transactions A, v. 6A, p.1345-1351, 1975.

240. CULLITY, B. D. Elements of X-ray diffraction. Reading, Massachusetts, USA: Addison-Wesley Publishing Company, Inc., $2^{\text {nd }}$ ed., 1978.

241. PECHARSKY, V.K.; ZAVALIJ, P.Y. Nature and poperties of $X$ ray. In: Fundamentals of powder diffraction and structural characterization of materials. New York, USA: Springer Science Ed., Chap. 2: Fundamentals of diffraction (2.2.1), 2005, $102-104$.

242. JENKINS, R.; SNYDER, R.L. Anisotropic distortions of the diffraction pattern. In:_. Introduction to $X$ ray powder diffraction. USA: Wiley Interscience Ed., Chap. 3: Diffraction Theory (3.9), v. 138, 1996, p. 85.

243. HE, J.; SCHOENUNG, J.M. Nanostructured coatings. Materials Science and Engineering A, v.336, p. 274-319, 2002.

244. RIETVELD, H.M.A. Profile refinement method for nuclear and magnetic structures. Journal of Applied Crystallography, v. 2, p. $65-71,1969$.

245. LARSON, A.C.; Von DREELE, R.B. General structure analysis system (GSAS). Los Alamos National Laboratory Report LAUR 86-748, Los Alamos, USA, 2004.

246. DYSON, D. J.; HOLMES, B. Effect of alloying additions on the lattice parameter of austenite. Journal of the Iron and Steel Institute, v. 1, p.469 - 474, 1970.

247. HERRERA, C. Microestrutura e textura de fitas ('tapes') de aço inoxidável dúplex produzidas por solidificação ultra-rápida ('melt-spinning'). Dissertação (Mestrado em Engenharia Metalúrgica e de Materiais), Escola Politécnica da USP, São Paulo, 2003. 
248. BORGES, J. F. A.; PADILHA, A. F.; IMAKUMA, K. Determinação da energia de defeito de empilhamento em metais e ligas com estrutura cúbica de face centrada por difração de raios X. Publicação IPEN 129, p. 1 - 12, São Paulo, 1988. 